\title{
GEOTHERMAL ENERGY REISOURCE INVESTIGATIONS IN THE EASTERN COPPER RIVER BASIN, ALASKA
}

Eugene M. Wes cott and Donald L. Turner Editors and Co-Principal Investigators

University of Alaska Geophysical Institute Report UAG R-302

\author{
Submit ked to:
}

Copper River Native Association, Inc. Contract No. AD-84-380 and

U.S. Department of Energy, Grant No. DE-FG07-841D12471

June 1985

\section{DISCLAIMER}

This report was prepared as an account of wo:k sponsored by an agency of the United States Government. Neither the United States Government nor any agency thereof, nor any of their employees, makes any warranty, express or implied, or assumes any legal liability or responsibility for the accuracy, completeness, or usefulness of any information, apparatus, product, or process disclosed, or represents that its use would not infringe privately owned rights. Reference herein to any specific commercial product, process, or service by trade name, trademark, manufacturer, or otherwise does not necessarily constitute or imply its endorsement, recommendation, or favoring by the United States Government or any agency thereof. The views and opinions of authors expressed herein do not necessarily state or reflect those of the United States Government or any agency thereof.

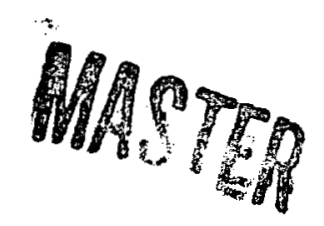




\section{DISCLAIMER}

This report was prepared as an account of work sponsored by an agency of the United States Government. Neither the United States Government nor any agency Thereof, nor any of their employees, makes any warranty, express or implied, or assumes any legal liability or responsibility for the accuracy, completeness, or usefulness of any information, apparatus, product, or process disclosed, or represents that its use would not infringe privately owned rights. Reference herein to any specific commercial product, process, or service by trade name, trademark, manufacturer, or otherwise does not necessarily constitute or imply its endorsement, recommendation, or favoring by the United States Government or any agency thereof. The views and opinions of authors expressed herein do not necessarily state or reflect those of the United States Government or any agency thereof. 


\section{DISCLAIMER}

Portions of this document may be illegible in electronic image products. Images are produced from the best available original document. 


\section{EXECUTIVE SUMMARY}

This report consists of a review of the geological, geochemical and geophysical data available for the eastern Copper River bas in with emphas is on the mud volcanoes, and the results of geophysical and geochemical studies carried out by the Univeristy of Alaska Geophysical Institute personnel in the summers of 1982 and 1984. The purpose of the work was to determine if there are geothermal energy resources in the Copper River Basin. Preliminary results from the 1982 work were reported in Wescott and Turner (1983). Although there are no obvious surface manifestations such as hot springs or geysers, there is ample reas on to suspect that the area may contain geothermal prospects. The eastern Copper River basin is situated on the flanks of a major volcano, Mt. Drum, which was active as late as 200,000 years ago and which is thought to have retained significant amounts of residual heat at high levels. Mt. Wrangell, farther to the east, has been volcanically active up to the present time.

The 1982 geophysical and geochemical surveys located three principal areas of possible geothermal interest, one near Tazlina and two near the Klawasi mud volcanoes. The intensive survey work of 1984 was concentrated on those areas. We have integrated the results of soil helium, soil mercury, gravity, aeromagnetic, electrical, self-potential, and controlled-source audio magnetotelluric (CSAMT) surveys to evaluate the geothermal potential of the area studied.

Chemical geothermometry studies of the waters coming from the Klawasi mud volcanoes has so far produced contradictory results: some chemical geothermometers indicate a cold water source, while others indicate a source of greater than $150^{\circ} \mathrm{C}$ (R. Motyka, pers. comm., 1982). The most recent 
studies of the Klawasi mud volcano waters (Hawkins and Motyka, 1985) have concluded that their chemistry does not require a geothermal source.

In the Klawasi mud volcano area the soil helium anomalies are encouraging, but other surveying methods produced equivocal results. The presence of extensive permafrost, with no obvious way to remove the heat arising from a geothermal source, and the low resistivity of the Klawasi mud argues against a significant geothermal resource in the mud volcano area.

The situation is less clear cut in the Tazlina area near the confluence of the Tazlina and Copper Rivers. There is little or no permafrost in this area. Although the geochemical and geophysical survey results could possibly indicate a geothermal resource, these same results could also have other, nongeothermal, explanations. The only way to further evaluate the potential for geothermal resources in this area would be to drill one or more test holes to measure thermal gradients directly. The CSMAT survey suggests that, if present at all, a geothermal reservoir would probably correspond to a low resistivity layer detected at approximately $2500 \mathrm{ft}$ depth.

Although the areas studied do not appear to have definite geothermal potential, it is clear that a major heat source exists at Mt. Wrangell and that a resource could also possibly be present at Mt. Drum.

\section{$\underline{\text { References }}$}

Hawkins, D.B. and Motyka, R.J., 1985, A multivariate statistical analysis and chemical mass balance analys is of waters of the Copper River basin, Alaska, in Wallick, E. and Hitchon, B., eds., Proceedings of lst Annual Canadian - American Conference on Hydrogeology, Banff, Alberta, 1984 (in press).

Wescott, E.M. and D.L. Turner, 1983, Final report on the geothermal energy resource potential of the eastern Copper River basin, Alaska, report submitted to Alaska Division of Geological and Geophysical Surveys, for RSA $82-5 X-670$ (in press). 


\section{TABLE OF CONTENTS}

CHAPTER 1 - SUMMARY AND EVALUATION OF GEOLOGIC, GEOCHEMICAL, AND GEOPHYSICAL DATA RELEVANT TO GEOTHERMAL ENERGY EXPLORATION IN THE EASTERN COPPER RIVER BASIN, ALASKA, by Donald L. Turner

and Eugene $M$. Wescott $\ldots \ldots \ldots \ldots \ldots \ldots \ldots \ldots \ldots \ldots \ldots \ldots \ldots \ldots \ldots \ldots \ldots$

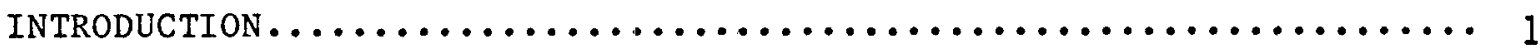

REGIONAL SETTING $\ldots \ldots \ldots \ldots \ldots \ldots \ldots \ldots \ldots \ldots \ldots \ldots \ldots \ldots \ldots \ldots \ldots \ldots$

BASIN STRUCTURE AND STRATIGRAPHY $\ldots \ldots \ldots \ldots \ldots \ldots \ldots \ldots \ldots \ldots \ldots \ldots \ldots$

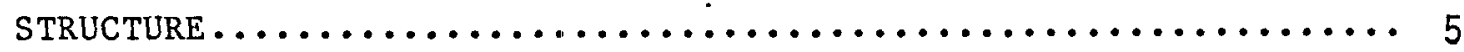

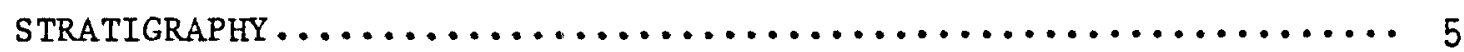

MUD VOLCANOES $\ldots \ldots \ldots \ldots \ldots \ldots \ldots \ldots \ldots \ldots \ldots \ldots \ldots \ldots \ldots \ldots \ldots \ldots \ldots$

MORPHOLOGY $\ldots \ldots \ldots \ldots \ldots \ldots \ldots \ldots \ldots \ldots \ldots \ldots \ldots \ldots \ldots \ldots \ldots \ldots$

GAS AND WATER ANALYSES $\ldots \ldots \ldots \ldots \ldots \ldots \ldots \ldots \ldots \ldots \ldots \ldots \ldots$

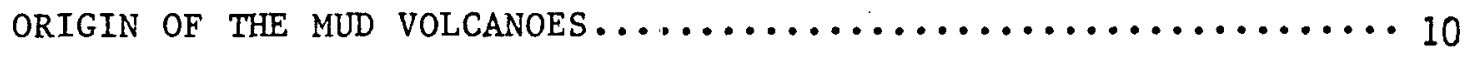

IMPLICATIONS OF THE MUD VOLCANOES FOR GEOTHERMAL EXPLORATION..... 16

PREVIOUS GEOPHYSICAL AND GEOCHEMICAL SURVEYS $\ldots \ldots \ldots \ldots \ldots \ldots \ldots \ldots \ldots$

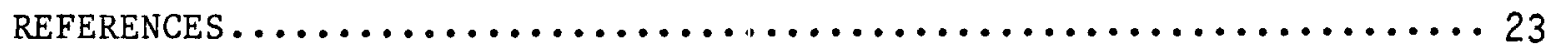

CHAPTER 2 - 1982 AND 1984 HELIUM SOIL SURVEY RESULTS IN THE

EASTERN COPPER RIVER BASIN, ALASKA, by Donald L. Turner and

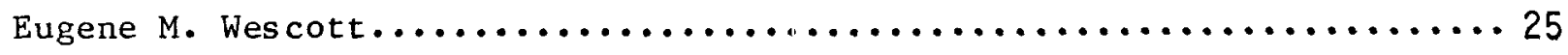

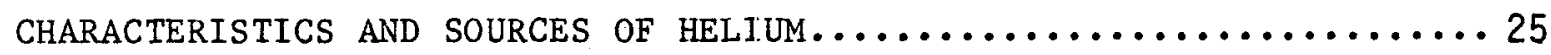

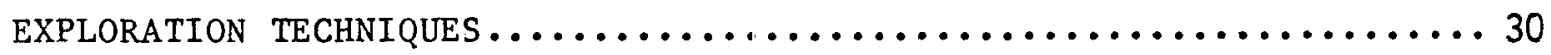

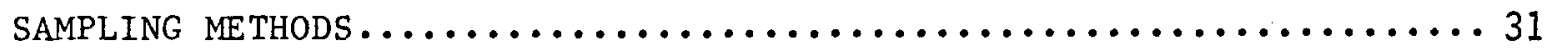

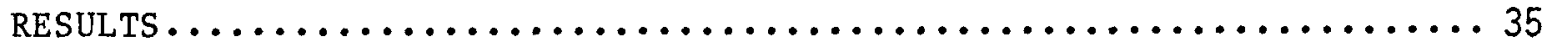

1982 SURVEY RESULTS .............................. 36

1984 SURVEY RESULTS....................................... 37 


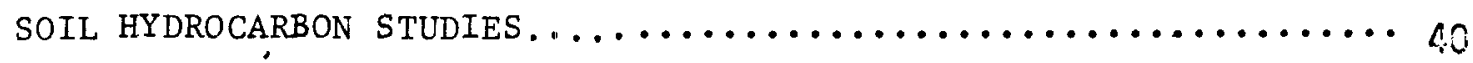

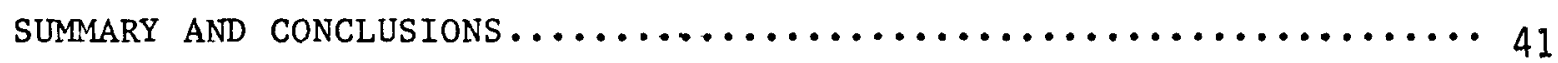

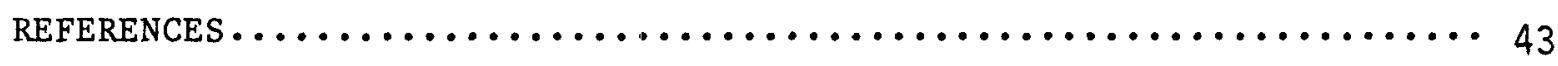

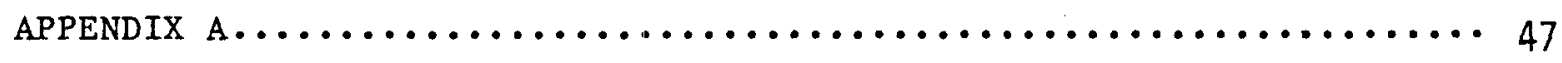

APPENDIX $\mathrm{B} . \ldots \ldots \ldots \ldots \ldots \ldots \ldots \ldots \ldots \ldots \ldots \ldots \ldots \ldots \ldots \ldots \ldots \ldots \ldots \ldots \ldots$

CHAPTER 3 - CORRECTION AND ANALYSIS OF 1984 COPPER RIVER BASIN

HELIUM SOIL GAS SURVEY DATA by Ki.m R. Green................. 67

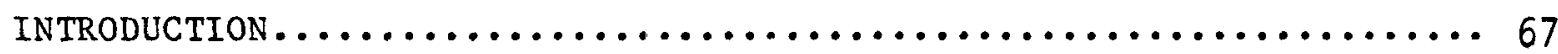

SAMPLING PROCEDURES.............................. 67

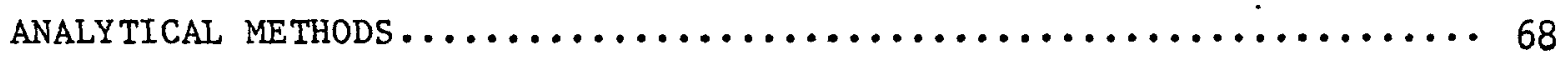

DATA TREATMENT....................................... 70

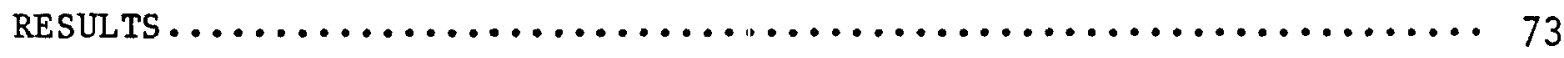

DIsCUSSION.......................................... 74

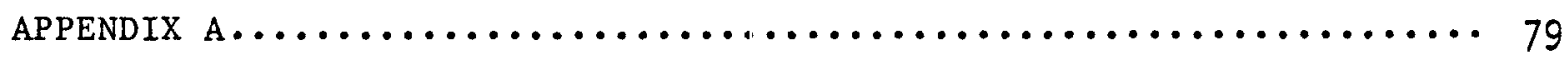

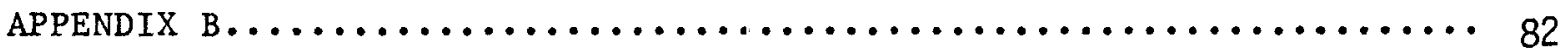

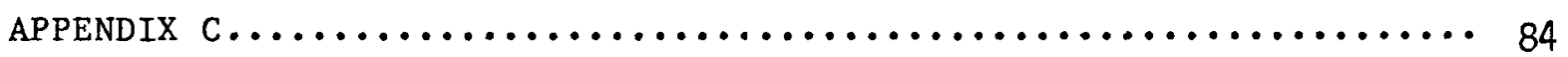

APPENDIX D.......................................... 87

CHAPTER 4 - MERCURY SOIL SAMPLING IN THE EASTERN COPPER RIVER

BASIN, ALASKA, by Eugene M. Wes cott and Donald L. Turner.............90

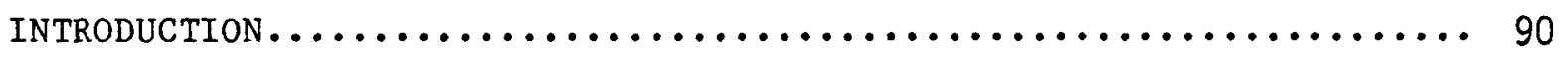

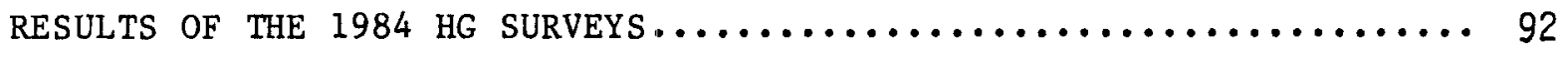

DISCUSSION OF RESULTS....................................... 94

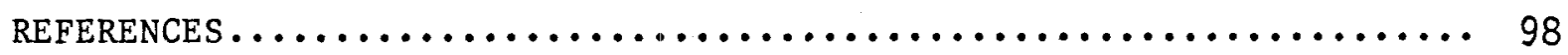

CHAPTER 5 - SELF-POTENTIAL SURVEYS IN THE EASTERN COPPER RIVER

BASIN, ALASKA, by Eugene M. Wescott..................... 99

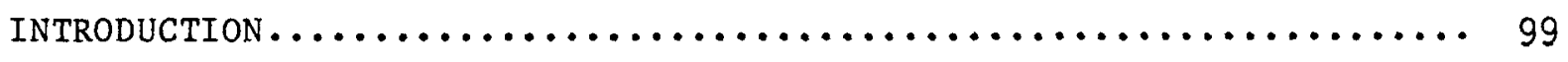

THE KLAWASI MUD VOLCANO GROUP SELF-POTENTIAL SURVEYS $(1982) \ldots \ldots \ldots 101$ 


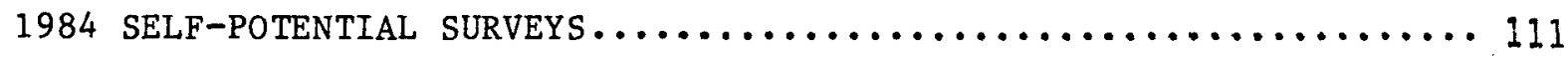

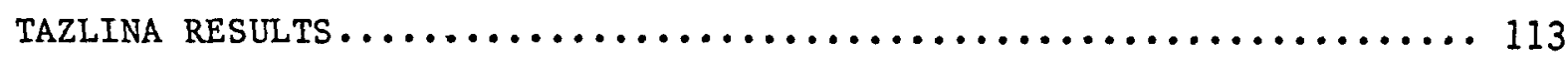

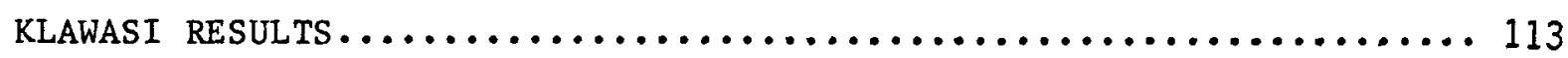

DISCUSSION OF 1984 RESULTS............................ 114

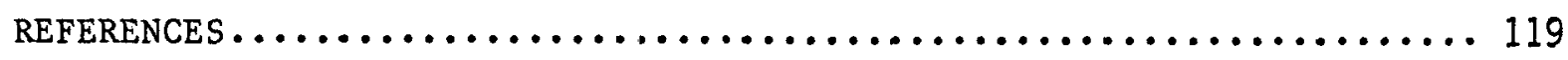

CHAPTER 6 - A GRAVITY SURVEY OF PART OF THE EASTERN COPPER

RIVER BASIN, ALASKA, by Eugene M. Wescott, Becky Petzinger,

William Witte, Donald L. Turner, and Gary Bender................. 120

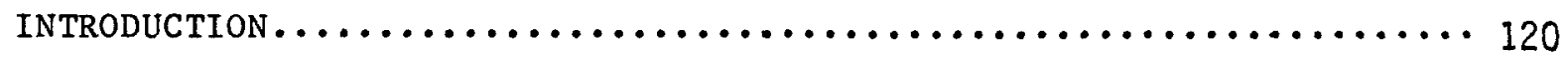

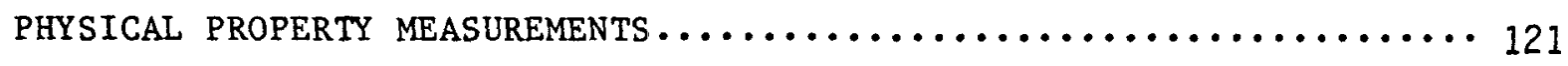

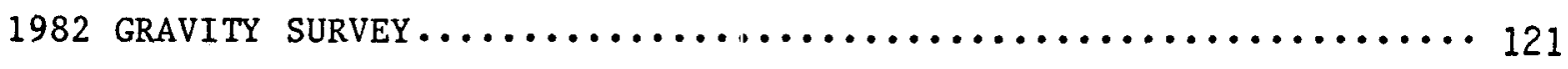

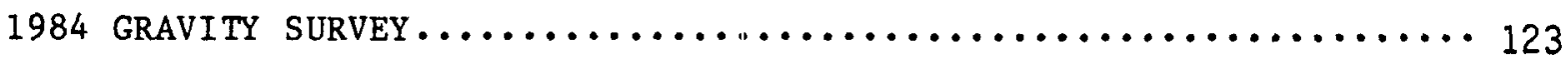

RESULTS AND INTERPRETATION............................ 124

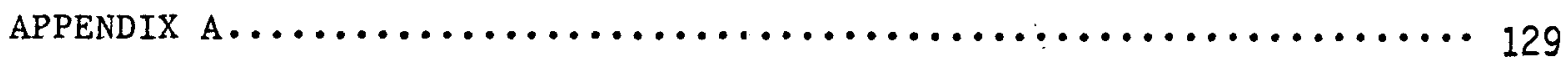

CHAPTER 7 - AEROMAGNETIC SURVEYS OF PART OF THE EASTERN

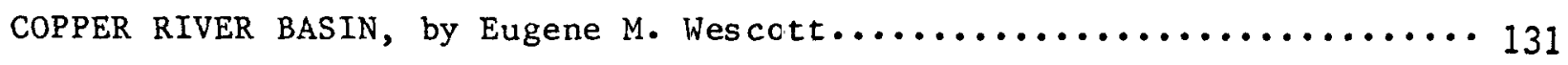

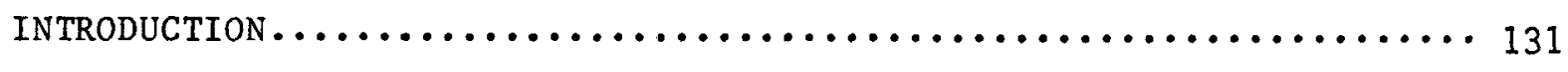

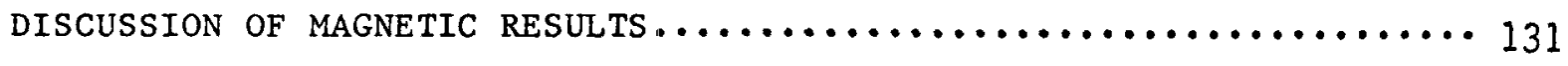

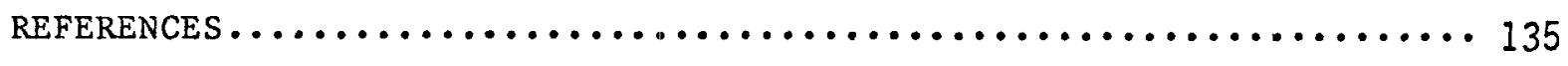

CHAPTER 8 - DEEP ELECTRICAL RESISTIVITY MEASUREMENTS by Eugene M.

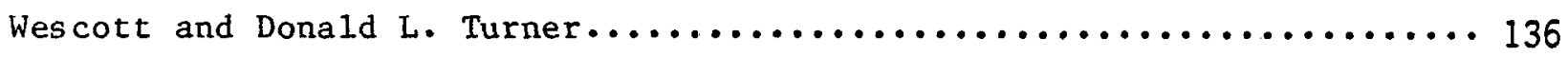

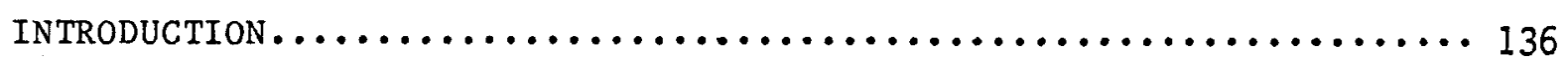

EXPLANATION OF THE CSAMT METHOD......................... 137

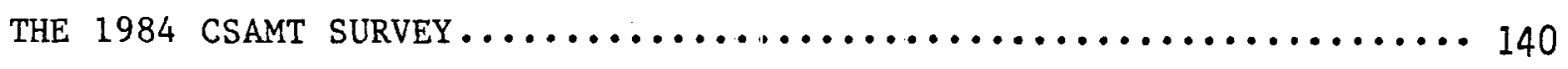

DISCUSSION OF DEEP ELECTRICAL RESISTIVITY RESULTS $\ldots \ldots \ldots \ldots \ldots \ldots 146$

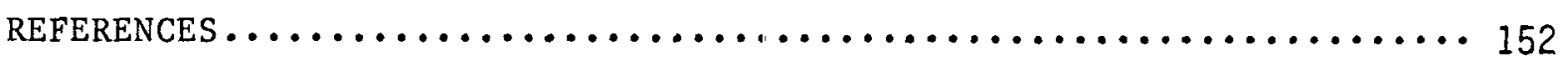


CHAPTER 9 - SUMMARY AND CONCLUSIONS by Eugene M. Wescott and

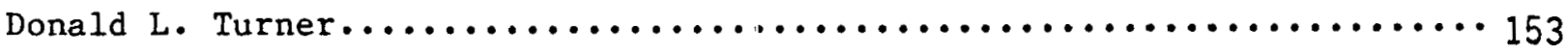

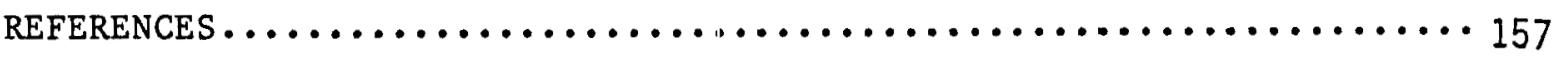

ACKNOWLEDGEMENTS ...................................... 158 


\section{LIST OF ILLUSTRATIONS}

FIGURE 1-1: GENERALIZED GEOLOGIC MAP OF THE COPPER RIVER BASIN..... 2

TABLE 1-1: COMPARISON OF CERTAIN PHYSICAL CHARACTERISTICS OF MUD VOLCANOES, COPPER RIVER BASIN, ALASKA............ 9

FIGURE 1-2: PRESSURE VS. DEPTH PLOT OF PAN AMERICAN MOOSE CREEK NO. 1 WELL................................ 12

TABLE 1-2: COMPARISON OF MUD VOLCANO AND GROUND WATER WITH PAN AMERICAN MOOSE CREEK NO. 1 WELL FLUIDS ............ 13

TABLE 1-3: COMPARISON OF CHEMICAL CONSTITUENT RATIOS OF WATER..... 14 FIGURE 1-3: DIAGRAMMATIC CROSS SECTION, COPPER RIVER BASIN....... 15

FIgURE 1-4: COMPLETE BOUGUER GRAVITY ANOMALY MAP.............. 19

FIGURE 2-1: SOLUBILITY OF NOBLE GASES IN FRESH WATER.......... 27

FIGURE 2-2: SCHEMATIC DIAGRAM OF A GEOTHERMAL RESERVOIR AS A HELIUM SOURCE......................... 28

FIGURE 2-3: SCHEMATIC DIAGRAM OF HELIUN MIGRATION ALONG FAULTS..... 29

FIGURE 2-4: SCHEMATIC DIAGRAM OF HELIUM OCCURENCES IN SOIL....... 32

FIGURE 2-5: HELIUM SOIL GAS SAMPLES ALONG THE GLENN HIGHWAY....... 38

FIGURE 2-6: CORRELATION DIAGRAM: 1984 HELIUM RESULTS FROM USGS AND

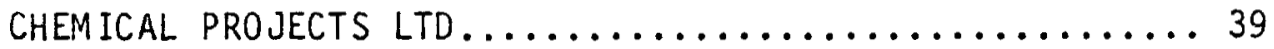

APPENDIX A: HELIUM SURVEY, A POSSIBLE TECHNIQUE FOR LOCATING GEOTHERMAL RESOURCES....................47

APPENDIX B: HELIUM SURVEYS, A SURVEY OF GEOTHERMAL PROSPECTS IN COPPER CENTER, GULKANA, ALASKA.................49

FIGURE 3-1: HISTOGRAM OF HELIUM CONCENTRATIONS IN GASEOUS SOIL

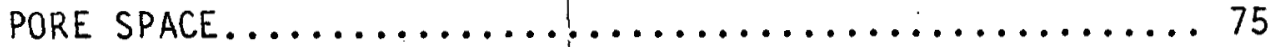

FIGURE $3-2$ : EXPANDED-SCALE HISTOGRAM OF FIGURE $3-1 \ldots \ldots \ldots \ldots \ldots$ APPENDIX A: EVALUATION OF METAL FOOD CAIVS AS HELIUM CONTAINERS..... 79 APPENDIX B: TABLE OF SOIL SAMPLE DATA FROM THE 1984 COPPER RIVER

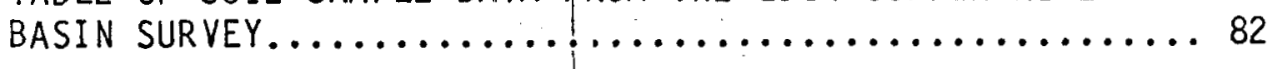

APPENDIX C: CORRECTED DATA FROM 1984 HELIUM SURVEY............ 84 APPENDIX D: EVALUATION OF POSSIBLE ERRORS IN THE CALCULATION OF HELIUM CONCENTRATIONS.................. 87 
FIGURE 4-1: HISTOGRAM OF 1984 MERCURY SOIL SURVEY ANALYSES........ 93

TABLE 4-1: MERCURY SOIL CONCENTRATION VALUES.............. 95

FIGURE $5-1$ : MAP OF SELF-POTENTIAL PROF ILES.................

FIGURE 5-2: NORTH-SOUTH SELF-POTENTIAL PROFILE A-A' ............ 104

FIGURE 5-3: WEST-EAST SELF-POTENTIAL PROF ILE B-B ' ............ 105

FIGURE $5-4:$ SELF-POTENTIAL PROFILE $c-c^{\prime} \ldots \ldots \ldots \ldots \ldots \ldots$

FIGURE $5-5: \quad$ SELF-POTENTIAL PROF ILE $D-D " \ldots \ldots \ldots \ldots \ldots \ldots \ldots$

FIGURE $5-6:$ SELF-POTENTIAL PROFILE E-E' ${ }^{\prime} \ldots \ldots \ldots \ldots \ldots \ldots$

FIGURE $5-7:$ SELF-POTENTIAL PROFILE F-F ${ }^{\prime} \ldots \ldots \ldots \ldots \ldots \ldots \ldots \ldots \ldots$

FIGURE 5-8: 1984 SELF-POTENTIAL SURVEY IN KLAWASI MUD VOLCANO AREA..112

FIGURE 5-9: 1984 SELF-POTENTIAL SURVEY PROFILE BETWEEN HELIUM

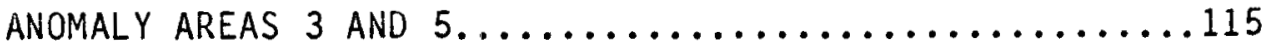

FIGURE 5-10: COMPARISON OF S-P PROFILE A-A' WITH AN S-P PROFILE ACROSS THE CERRO PRIETO GEOTHERMAL FIELD...........118

TABLE $6-1:$ PHYSICAL PROPERTY DETERM INATIONS ................

FIGURE 6-1: GRAVITY ANOMALY PROFILE NW-SE ACROSS GRAVITY TROUGH,

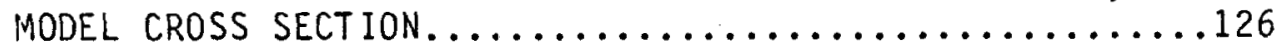

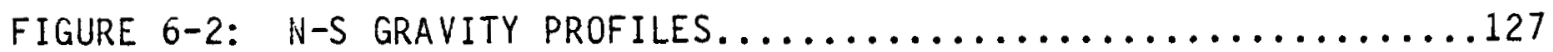

APPENDIX A: COPPER RIVER BASIN GRAVITY STATIONS ..................

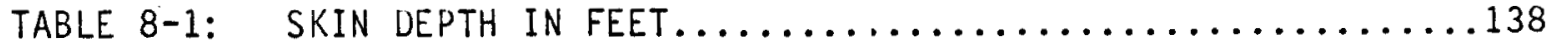

FIGURE 8-1: VES \#1 VERTICAL ELECTRICAL RESISTIVITY SOUNOING DATA. .. 142

FIGURE 8-2: VES \#2 VERTICAL ELECTRICAL RESISTIVITY SOUNDING DATA... 143

FIGURE 8-3: LOCATIONS OF VERTICAL ELECTRICAL SOUNDINGS...........144

FIGURE 8-4: CONTROLLED-SOURCE AUDIO MAGNETOTELLURIC PSEUDO-

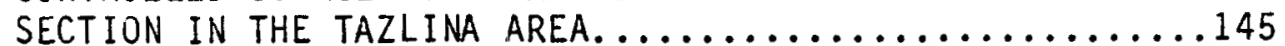

FIGURE 8-5: RESISTIVITY VS. DEPTH SECTION ACROSS THE TAZLINA

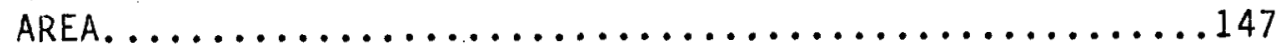

FIGURE 8-6: LOCATIONS OF TRANSMITTING AND RECEIVING STATIONS FOR CSAMT SURVEY IN KLAWASI MUD VOLCANO AREA............148

FIGURE 8-7: APPARENT RESISTIVITY PSEUDO-SECTION ACROSS THE TWO MAJOR HEL IUM ANOMALY AREAS IN THE KLAWASI MUD VOLCANO AREA. ... 149 
PLATE 1: 1982 HEL IUM SOIL, SOIL GAS AND WATER SURVEY......... IN POCKET

PLATE 2: 1984 HELIUM SOIL SURVEY (U.S.G.S. ANALYSES)........."

PLATE 3: 1984 HELIUM SOIL SURVEY (CHEMICAL PROJECTS LTD.

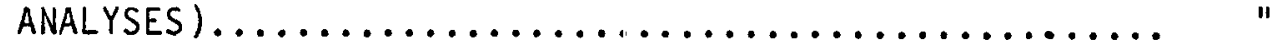

PLATE 4: $\quad 1984$ MERCURY SOIL SURVEY................... "

PLATE 5: 1984 HELIUM, MERCURY AND SELF-POTENTIAL SURVEY OF THE " TAZLINA AREA ON PHOTOGRAPHIC BASE............... "

PLATE 6: RESIDUAL GRAVITY AND SELF-POTENTIAL SURVEY MAP......."

PLATE 7: CORRECTED BOUGER GRAVITY MAP $\ldots \ldots \ldots \ldots \ldots \ldots \ldots \ldots$

PLATE 8: $\quad$ AEROMAGNETIC MAP....................... 
CHAPTER 1

SUMMARY AND EVALUATION OF GEOLOGIC, GEOCHEMICAL, AND GEOPHYSICAL DATA RELEVANT

TO GEOTHERMAL ENERGY EXPLORATION IN THE EASTERIN COPPER RIVEK BASIN, ALASKA

By

Donald L. Turner and Eugene M. Wescott

INTRODUCTION

The Copper River Basin is an intermontane structural basin ranging from 500 to $4,000 \mathrm{ft}$ above sea level and rimmed by 4,500 to $16,500 \mathrm{ft}$ peaks of the Alaska Range and the Talkeetna, Chugach, and Wrangell Mountains. Rock units bordering the basin range in age from middle(?) Paleozoic to Tertiary and consist dominantly of schist, greenstone, graywacke, slate, shale, and sandstone, locally associated with minor amounts of altered limestone, tuffs, and lava flows, and are intruded by a wide variety of igneous rocks. The Tertiary to Quaternary andesite lavas of the Wrangell Mountains form the eastern border of the basin. A generalized geologic map of the basin is shown in Figure 1-1.

Two groups of mud volcanoes occur in the basin. The Tolsona group consists of several gas seeps and four cones ranging in helght from 25 to $60 \mathrm{ft}$ and occurring immediately north of the Glenn Highway, about $12-15$ rif west of Glennallen. Three of these cones are active, and discharge methane and nitrogen, and water containing dissolved chlorides of sodium and calcium. The Drum group consists of three mud volcanoes and occurs about 7 $15 \mathrm{mi}$ east of the Copper River, on the lower part of the western flank of Mt. Drum. These three cones range in height from $150 \mathrm{ft}$ (lower Klawasi) to $310 \mathrm{ft}$ (Shrub). The three cones discharge $\mathrm{CO}_{2}$ and warm $\mathrm{NaCl}$ and bicarbonate waters. The small size of these cones and their lack of included angular rock fragments suggest that they formed by gradual accretion of mud, rather than by explosive activity (Nichols and Yehle, 196la). 
One or more of the Drum group may have been formed by hydrothermal activity, as suggested by the geothermometry of their discharged waters. However, other non-thermal models call also be suggested for their formation, as will be discussed later. In general, the anticipated high heat flow in the region of the Wrangell volcanoes, the suspected presence of abundant subsurface acquifers in the basin, the inferred presence of subsurface impermeable lava flows and claystone beds that could serve as cap rocks, and perhaps the presence of the mud volconoes themselves, all suggest that the easternmost part of the Copper River basin is a promising area for geothermal energy exploration.

\section{REGIONAL SETTING}

The geographic setting of the Copper River basin is shown in Figure 11. The Cenozoic topographic and structural basin covers $5,400 \mathrm{sq} \mathrm{mi}$, and is rimmed by $4,500-t o-16,500$ ft mountain peaks. It is poorly drained; impounded water results in numerous lakes, pondis, and swamps connected by meandering streams and rivers. Exterior drainage is accomplished only by the Copper River which has incised a deep canyon through the Chugach Range to the south, and by the Oshetna River which combines with the Susitna River to cut through the Talkeetna Mountains to the west. The basin is barred from drainage to the north by low hills that form the soutr margin of the Alaska Range, and on the east by the great volcanic cones of the Wrangell Mountains.

Glacial, lacustrine, and alluvial deposits which probably exceed $1,000 \mathrm{ft}$ where thickest cover the basin, effectively concealing older rocks (Mendenhall, 1905). There are, however, a few areally restricted outcrops of continental deposits of Eocene age. In the east part of the basin the Quaternary deposits are several hundred feet thick. The basin lies in the zone of discontinuous permafrost. Permafrost is probably present everywhere 
in the basin except beneath large lakes and major streams. It lies 1 - $2 \mathrm{ft}$ below the surface in some muskegs, 2 - $5 \mathrm{ft}$ deep in lacustrine and finegrained glacial deposits and six-to-more-than-ten-ft deep in granular alluvial and glacial deposits. It generally ranges from 100 to $200 \mathrm{ft}$ thick, has a high ice content and is marginal in temperature, about -0.5 to $-1.5^{\circ} \mathrm{C}$. The permafrost is in a delicate state of equilibrium, and construction projects can result in considerable subsidence (Schultz and Smith, 1965).

Underlying most of the western part of the basin are Cretaceous shale and sandstone of the Matanuska Formation and semi-consolidated continental Tertiary sandstone and conglomerate with a few lignitic beds (Miller and others, 1959). To the east, however, an aeromagnetic survey suggests that Tertiary lavas and Pleistocene unconsolidated deposits underlie a thin veneer of Quaternary cover, and extend at least as far west as the Copper River (Andreasen, 1964).

The northern margin of the basin is formed by isolated hills of Permian volcanic rocks that merge northward into mountains made up of basalt and andesite of Permian and Triassic age. The Wrangell Mountains bordering the east part of the basin are Tertiary-to-Quaternary volcanoes which have erupted vast amounts of andesitic lava over surrounding older rocks. The flows have slowly forced the channel of the Copper River westward until it now flows around the great volcanic edifice in a huge arc. The hills bordering the southeast corner of the basin are formed of metamorphic rocks of Mississippian age. Metamorphosed sedimentary rocks of Mesozoic age are exposed in the hills at the extreme southeast margin of the basin. 


\section{BASIN STFUCTURE AND STRATIGRAPHY}

\section{Structure}

The Copper River Basin is both a structural and a topographic basin. Quaternary glacial and alluvial deposits and local continental deposits of Eocene age are present over most of the basin and concesl the older rocks. Pre-Eocene rocks form eastward-trending arcs that are concave south. These arcs have existed since Mesozoic and earliest Tertiary time. They are delineated by the strike of geologic contacts, faults, and topographic features. Two arcuate belts of lower Jurassic and older rocks containing numerous plutonic bodies are called the Seldovia and Talkeetna geanticlines. These geanticlines trend eastward through the northern part of the Chugach Mountains and the northern half of the Copper River Basin, respectively. Between these geanticlines lies a belt of middle Jurassic to late Cretaceous marine sediments called the Matanuska geosyncline (Fig. 1-1). These rocks trend into the Copper River Basin from the Matanuska Valley on the west and from the Chitina Valley on the southeat, but they are exposed at only a few places within the basin itself (Andreasen and others, 1964).

\section{Stratigraphy}

Thus far, the only detailed stratigraphic studies of the basin are proprietary studies by various oil companies. However, two cross sections based on eight wells drilled to depths of approximately 2,800 to 8,800 ft have been published by the Alaska Geological Society (Church and others, 1969). These sections cover the central, southern, and southeastern perts of the basin. The easternmost well, Pan American Moose Creek Unit No. 1, was drilled to a total depth of $7,869 \mathrm{ft}$. This well is located approximately $20 \mathrm{mi}$ eastnortheast of the Lower Klawasi mud volcano and about $5 \mathrm{mi}$ east of the Tolsona group of mud volcanoes. It penetrated the following section: 
$0-920 \mathrm{ft}$

Unconformity

$920-4,125 \mathrm{ft}$

$4,125-4,820 \mathrm{ft}$

Unconformi ty

$4,820-6,755 f t$

Unconformity

$6,755-7,869$ T.D.

Quaternary and Tertiary? (Note: Nichols and Yehle (1961) state that the southeast part of the basin, perhaps including the Tolsona group, is underlain by semi-consoliclated Tertiary sandstone and conglomerate with a few lignite beds).

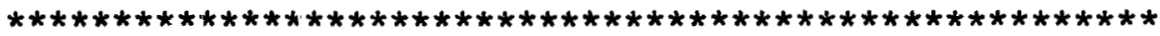

U. Cretaceous - Matanuska Formation marine shales with occasional fine-grained sandstones.

Basal Upper Cretaceous - Basal Matanuska Formation fine-grained marine sandstones with minor interbedded shales.

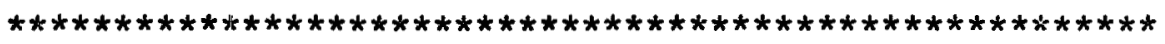

Lower Cretaceous Kennicott and possibly Nelchina Formations - marine shales with two fine-grained quartzose sandstone units in the lower middle portion of the drilled interval. The uppermost of these sandstones produced a water flow with methane, along with tar showis.

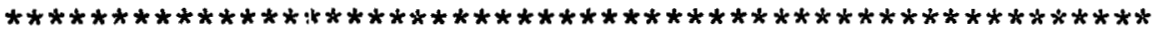

Upper Jurassic Naknek and Chitina Formations marine tuffaceous sandstones and shales.

The Middle Jurassic Tuxedni Formation, consisting of marine shales and interbedded sandstones is believed to underlie the Naknek and Chitina Formations, based on subsurface extrapolations from deeper wells to the west.

Two additional wells have been drilled for the Ahtna Corp., by Anoco near Gulkana, about 12 and $15 \mathrm{mi}$, respectively, northwest of the Lower Klawasi mud volcano. Stratigraphic information from these wells is now in the public domain. The following information is avallable for these wells: AMoco Ahtna No. 1 - Sec. 18., T6N, RIW

Total depth $7,941 \mathrm{ft}$

Temperature at T.D. $138^{\circ} \mathrm{F}$

Encountered 'bedrock' at T.D. 
$1,080-5520 \mathrm{ft}$

$5880-6150 \mathrm{ft}$

$6510-6720 \mathrm{ft}$

$6,710 \mathrm{ft}$

$7,923-7928 \mathrm{ft}$
Upper Cretaceous Matanuska Formation based on foraminifera" Dominantly shale with some sandstone near base of section. No Nelchina formation present.

No samples

Lennomanian t:o Albian (mid Cretaceous) foraninifera Top of Jurassic based on paleontology. Sandstone composed of metavolcanic grains.

Olivine basalt, density 2.7 to 2.8 .

A slight gas show consisting almost entirely of methane, and a "fairly strong", highly saline $(35,000 \mathrm{ppm}$ chloride) water flow were encountered at $7,100 \mathrm{ft}$. The flow from this sightly overpressured zone died out quickly and there was no indication of a highly overpressured zone as occurs in the Moose Creek well discussed above. The final shut in pressure was 3,220 psi. A thin coal bed was noted at $4,530 \mathrm{ft}$.

AMOCO Ahtra No. A-1 - Sec. 2.2, T5N, RlW

Total depth $-5,577 \mathrm{ft}$

Temperature at T.D. $-118^{\circ} \mathrm{F}$

Encountered 'bedrock' at T.D.

$710 \mathrm{ft}$

$1,020 \mathrm{ft}$

$4,864 \mathrm{ft}$

$5,575 \mathrm{ft}$

From 2,100 to $2,300 \mathrm{ft}$
Miocene sediments - clays, gravels, siltstone, shales.

Top of Matanuska Formation - mostly siltstone with a few sand layers.

Talkeetna Formation - primarily siltstone with a limestone layer from 5,025 to $5,045 \mathrm{ft}$ and some thin tuff layers.

Basement - probable greenstone with some quartzite.

There were natural gas shows and indications of carbons in the drilling mud. Near 2,337 ft the hole collapsed and there was a salt water flow. The mud weight was increased from 8.9 to $15.6 \mathrm{lb} / \mathrm{gal} 81$ percent of lithostatic pressure). Further salt water flow was indicated at $2,520 \mathrm{ft}$ where the mud weight was increased to $16 \mathrm{ppg}$. 
MUD VOLCANOES

Morphology

The two groups of mud volcanoes in the basin have been described in detail by Nichols and Yehle (1961) and Grantz and others (1962). The morphology, surface water temperatures, and estimated discharge rates of these mud volcanoes are shown in the following table from Nichols and Yehle (1961). In the Klawasi group (Table 1-1) the Shrub and Upper Klawasi cones have drumlinoid profiles and are mantled by glacial drift consisting of coarse, gravelly sand and striated erratics up to $5 \mathrm{ft}$ in diameter. In contrast, Lower Klawasi has a nearly symmetrical cone which has no traces of glacial drift or glacio-lacustrine deposits. Lower Klawasi has clearly had conebuilding activity much later in time than the other two mud volcanoes in the Drum group as evidenced by large numbers of killed spruce trees standing.

In the Tolsona group (Table 1-1) the Nickel Creek mud volcano is similar to the Shrub and Upper Klawasi cones, while the Shepard and Tolsona cones are miniature replicas of the Lower Klawasi cone. The Tolsona cones all lie below nearby strandines from the glacial lake and are capped by probable glaciolacustrine deposits. The low, broad shield-type cones of Lower Klawasi, Shepard, Tolsona No. I and Tolsona No. 2 have apparently developed during or after melting of the glaclers in the basin. However, the springs which built all of the mud volcanoes could be muck older than the present cones. Gas and water analyses

Gas and water analyses from the mud volcanoes and springs have been reported by Nichols and Yehle (1961) and Grantz and others (1962). All gas samples from the Drum (Klawasi) group are dominantly carbon dioxide with minor amounts of nitrogen. The Tolsona group gases, however, have 48 percent or more methane and a negligible amount of $\mathrm{CO}_{2}$, the remainder being largely 
TABIE I- I

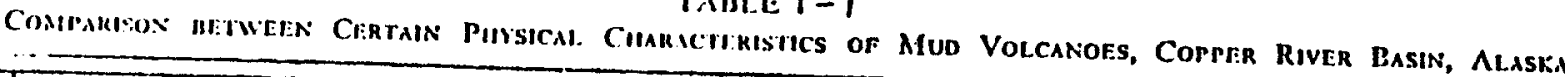

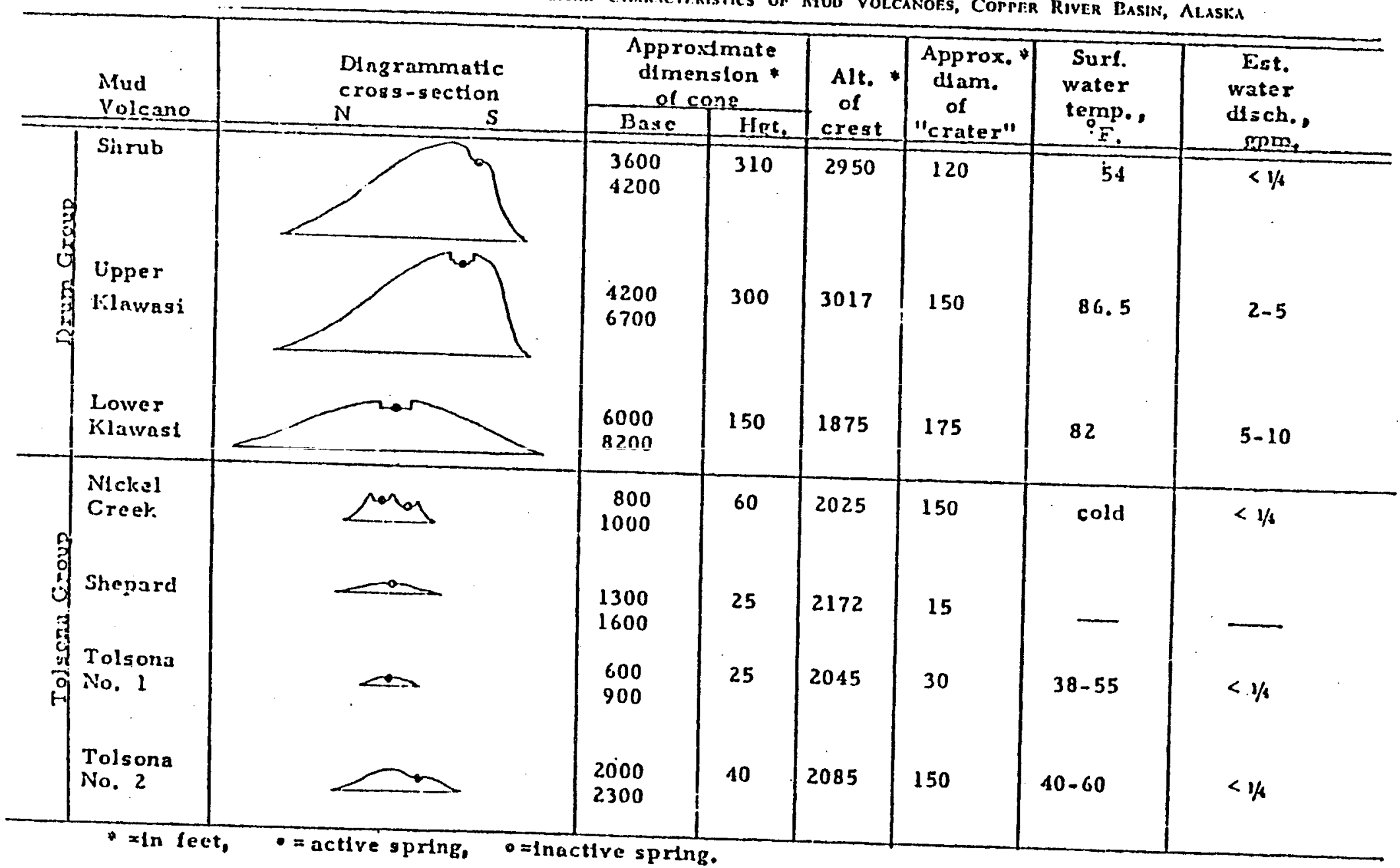

(From Nichols and Yefile (1961)) 
nitrogen. These striking differences suggested to these authors that the gases are derived from entirely different sources, with the Tolsona group, probably being derived from buried marsh and coal deposits. Gas in the Drum group, however, may emanate in part from volcanic sources, although their extremely high $\mathrm{CO}_{2}$ content is enigmatic.

The water of the Drum group is also believed by Nichols and Yehle (196I) to possibly include a volcanic component. All of the spring waters analyzed are highly saline, but there are significant differences, most notably the relatively high bicarbonete content of the Drum group, along with their significantly higher silica, magnesium, sodium, potassium, and boron content. Sulfate is also high at Lower Klawasi. The Tolsona group waters have consistently higher iron and caloium, and chloride is almost their sole anion.

Grantz and others (1962) have shown that the highly saline waters that reach the surface in a large area of the Copper River Basin at about 1,0003,000 ft above sea level (Fig. 1-1) are likely to have originated as connate formation waters in the Upper Cretaceous and older marine sedimentary rocks underlying the basin. They recognized two different types of saline waters emanating from the two groups of mud rolcanoes: a sodium-calcium-chlorine or Tolsona type, and a sodium-chlorine- $\mathrm{HCO}_{3}$ or Klawasi (Drum group) type. The Tolsona type is relatively widespread in the basin, but the Klawasi type appears to be confined to the west slope of Mt. Drum. Origin of the mud volcanoes

Abundant, unabraded Upper Cretaceous fossils in the mud at the Tolsona and Klawasi cone vents suggest that part of the cone-building material may have been derived directly from underlying Upper Cretaceous marine sediments at depth. Foresman (1970) has pointed out that the Tolsona and Klawasi cone 
deposits contain about 12 species which are also found in the Upper Cretaceous sections of two wells drilled in the basin.

In addition to the paleontologic: data, Foresman (1970) has compared the water chemistry of the mud volcanoes with analysis of formation waters that flowed from a highly overpressured zone below $5,200 \mathrm{ft}$ depth in the Lower Cretaceous section of the Pan American Moose Creek Unit No. 1 well, located about $4 \mathrm{mi}$ east of the Tolsona group of mud volcanoes. Figure 1-2 is a plot of pressure vs depth in this well.

Tables 1-2 and 1-3 compare the chemistry of water from $6,074 \mathrm{ft}$ depth in - the Moose Creek well with water from the mud volcanoes and with oil field brines. The different chemistries of the two mud volcano groups suggest that they are composed, at least in part, of water of different origin. The Tolsona springs and the water from the Moose Creek well are very similar and lie in the middle range of oil field brines (Foresman, 1970). Foresman argues that the water chemistry similarities and the occurrence of the same fossils indicate that the Copper River Basin nud volcanoes are directly related to the abnormal pressures encountered at depth in the Moose Creek well. The Upper Cretaceous age of the fossils mantling, the mud volcanoes vs, the Lower Cretaceous age of the strata of the overpressured zone in the Moose Creek well suggests that these fossils were derived from overlying, younger strata by upward movement of mud from the overpressured zone. He speculates that the zone of high pressure in the Cretaceous basin strata is a result of loading by the relatively young $12,000-16,000 \mathrm{ft}$ thick volcanic edifice of the Wrangell Mountains. These relationships are shown diagrammatically in Figure 1-3, a hypothetical cross section along the line A-Al of Figure 1-1.

Foresman further speculates that the very large area covered by the salinity anomaly in the basin (Fig. 1-1) is caused by abnormally high pressure 


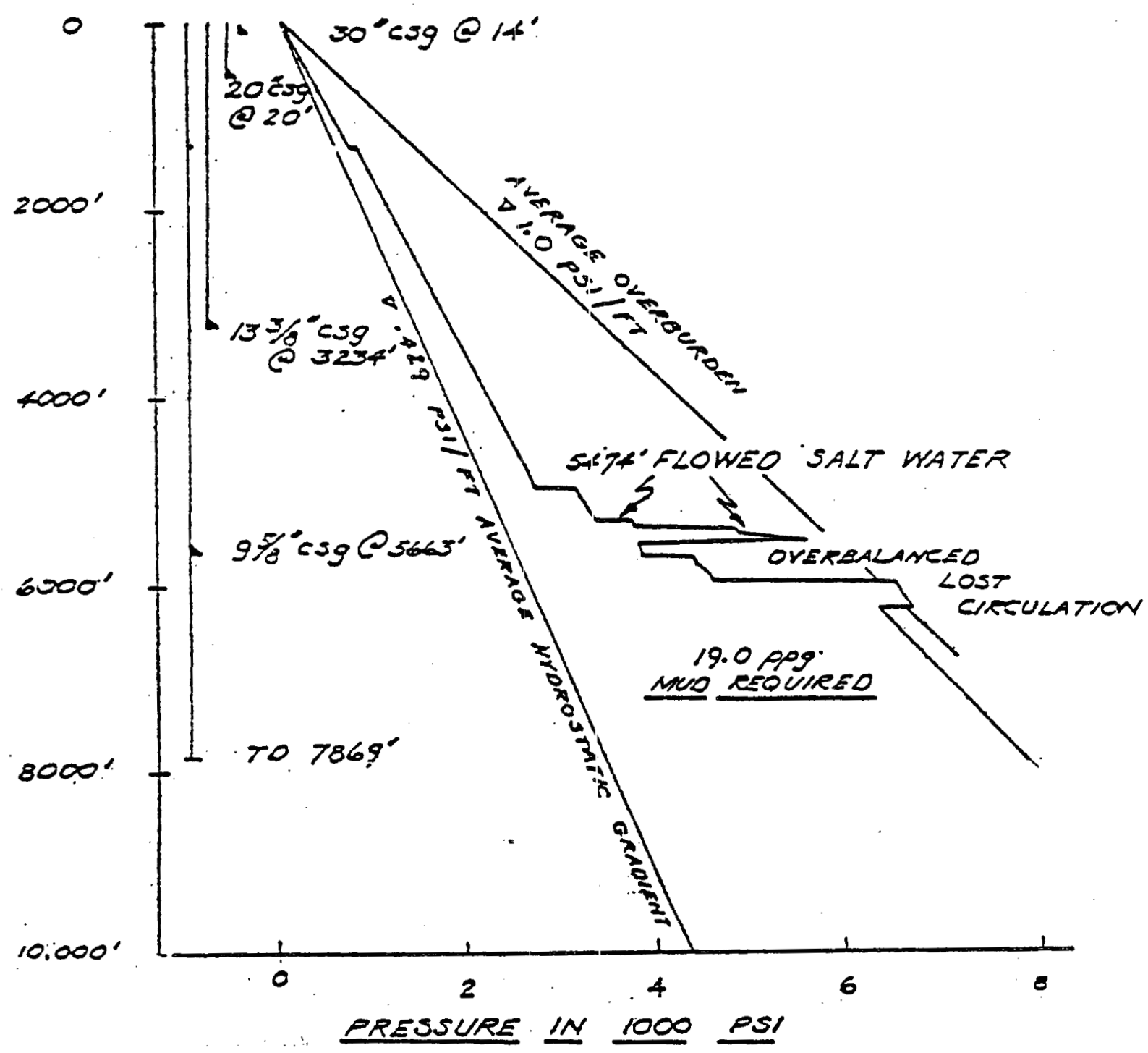

Figure 1-2. Pressure vs. depth pl ot of Pan American Mose Creek No. 1 well indicates top of abnormal pressures at 5200'. Pressures estimated to be 5750-6100 pisi (Foresman, 1970). Sizes of casing (csg) used are shown at left. 
TMBLE 1-2. COMPARISOH OF HUD VOLCANO AND GROUND WATER HITH FLUIOS ANALYZED AT 6075' IN THE MOOSE CREEK 1, COPPER RIVER BASIN, ALASKA (Foresman, 1970) (Chemical concentrations in parts per mililion)

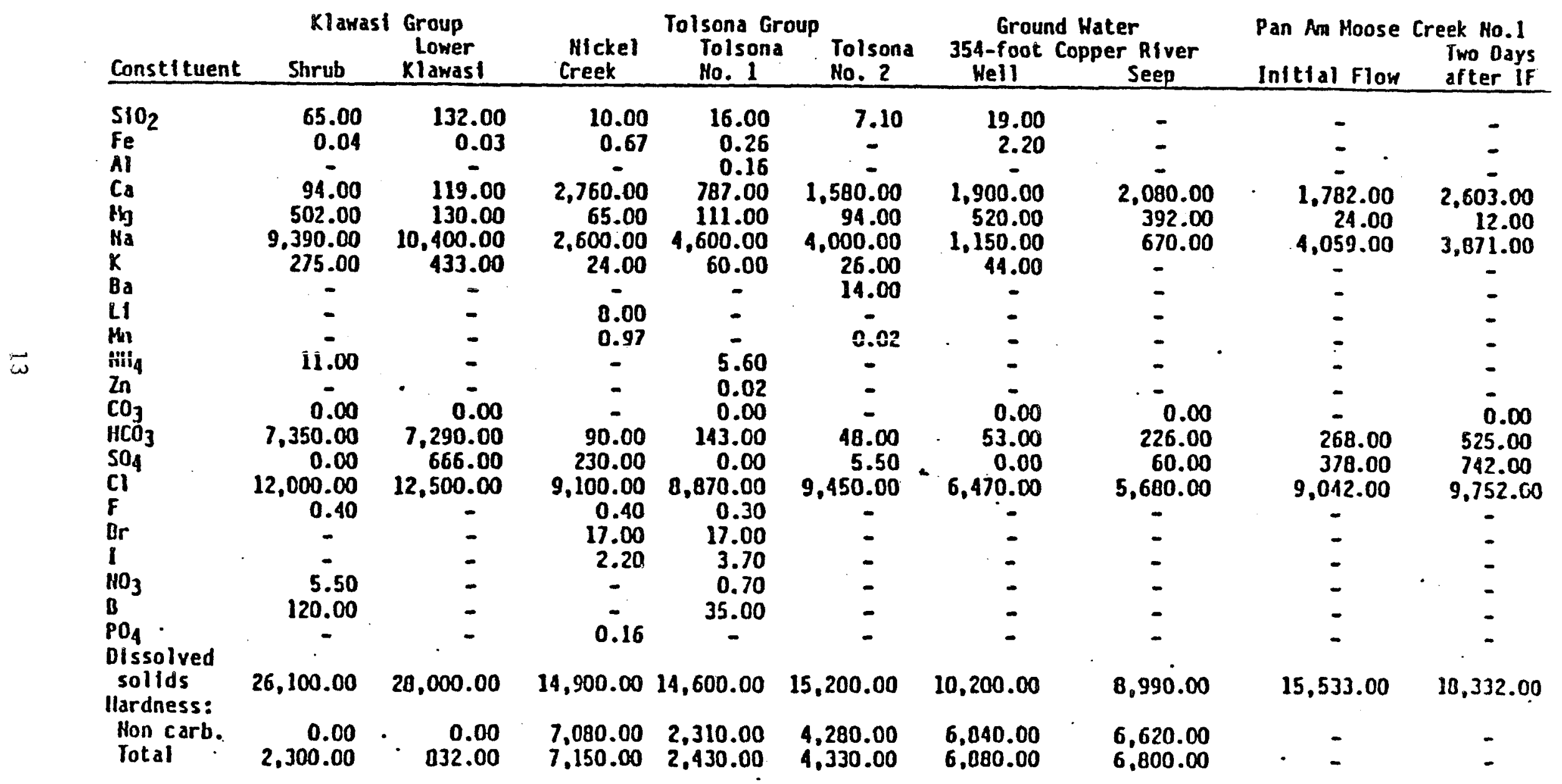


TABLE 1-3. COMPARISON OF CHEHICAL CONSTITUENT RATIOS OF MATER FROM THE COPPER RIVER BASIH (Foresman, 1970)

\begin{tabular}{|c|c|c|c|c|c|c|c|c|c|c|c|}
\hline Ratios & $\begin{array}{c}\text { Klawasi Gro } \\
\text { Shrub } \\
\end{array}$ & $\begin{array}{l}\text { Lower } \\
\text { Klawasi }\end{array}$ & $\begin{array}{r}\text { Mickel } \\
\text { Creek }\end{array}$ & $\begin{array}{c}\text { Tolsona Gro } \\
\text { Tolsona } \\
\text { Mo.1 }\end{array}$ & $\begin{array}{c}\text { Tolsona } \\
\text { Ho.2 }\end{array}$ & $\begin{array}{c}\text { Grour } \\
\text { 354-ft } \\
\text { Hell } \\
\end{array}$ & $\begin{array}{c}\text { dwater } \\
\text { Copper R. } \\
\text { Seep } \\
\end{array}$ & $\begin{array}{c}\text { Pan } \\
\text { Hoose } \mathrm{Cr} \\
\text { Initial } \\
\text { flow } \\
\end{array}$ & $\begin{array}{l}\text { Ho. } 1 \\
\text { Two days } \\
\text { after If }\end{array}$ & $\begin{array}{c}\text { Oll-fi } \\
\text { Brines A } \\
\text { Range } \\
\end{array}$ & $\begin{array}{l}\text { eld } \\
\text { pprox. }\end{array}$ \\
\hline $\mathrm{ICO}_{3} / \mathrm{Cl}$ & 0.6125 & 0.5832 & 0.00989 & 0.01612 & 0.00508 & 0.0082 & 0.0400 & 0.02964 & 0.05381 & 0.0001 & -1.0 \\
\hline $\mathrm{SO}_{4} / \mathrm{Cl}$ & 0.00 & 0.05320 & 0.02527 & 0.00 & 0.000582 & 0.00 & 0.0106 & 0.41805 & 0.07609 & 0.00 & -1.0 \\
\hline$F / C)$ & - 0.000033 & - & 0.000044 & 0.000034 & - & - & - & - & - & 0.00001 & $1-0.001$ \\
\hline orici & - & - & 0.001868 & 0.001916 & - & - & - & - & - & 0.0001 & -0.01 \\
\hline $\mid / C l$ & - & - & 0.000242 & 0.000417 & - & - & $=$ & - & - & 0.00003 & $3-0.02$ \\
\hline$B / C I$ & 0.01 & - & - & 0.003945 & - & - & - & - & - & 0.00001 & $1-0.02$ \\
\hline $\mathrm{K} / \mathrm{Ka}$ & 0.0293 & 0.0416 & 0.00923 & 0.01288 & 0.0065 & 0.038 & - & - & - & 0.001 & -0.003 \\
\hline $\mathrm{LI} / \mathrm{lla}$ & - & - & 0.00308 & - & - & - & - & - & - & 0.0001 & $-0.00 \mathrm{\jmath}$ \\
\hline$\frac{C_{a}+H_{g}}{H_{a}+K}$ & 0.0617 & 0.02299 & 1.0766 & 0.19025 & 0.4158 & 2.027 & 3.70 & 0.4494 & 0.6756 & 0.01 & -5.0 \\
\hline
\end{tabular}




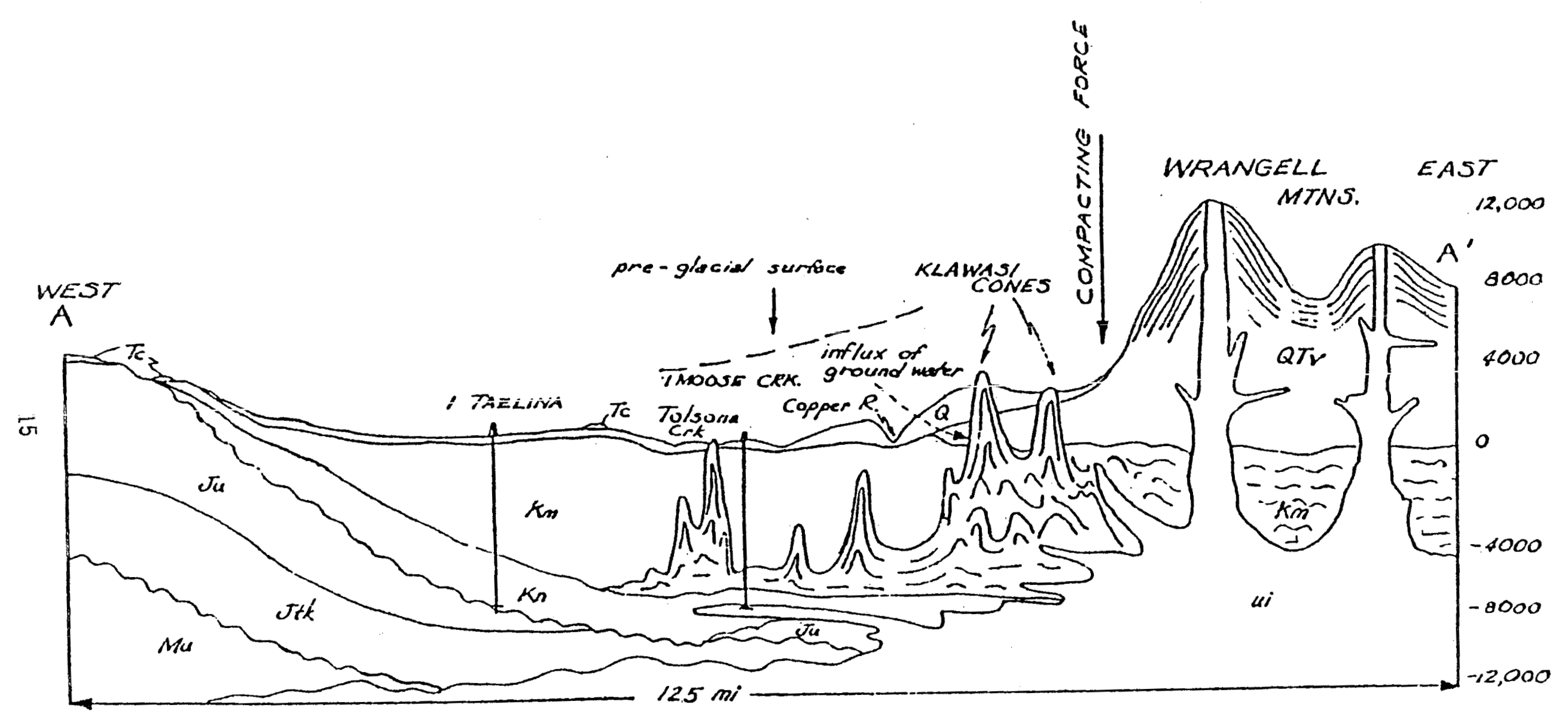

Figure 1-3. Diagrammatic cross section of the Copper River Basin showing the stratigraphy and the relationship of high pressure and mud volcanoes to compacting force produced by the Wrangel1 ittns. Vertical exaggeration about 10X. (Foresman, 1970). 
forcing connate water from underlying marine sediments upward into the ground water table.

Foresman's arguments appear convincing for the origin of the Tolsona group of mud volcanoes, and may also, by analogy, explain the origin of the Drum group, although the data are not as convincing for the latter. Foresman does not discuss the effect of the loading of glacial ice (thickness $1,000 \mathrm{ft}$ ) and the large pro-glacial ice lake that filled the Copper River Lowland during the last major glacial advance. Grantz and others (1962) have suggested that the increased lithostatic pressure due to the weight of the ice and the lake may have increased the discharge of water and gas in the springs that build the mud volcanoes. These authors point out that the present cones may have attained most of their bulk during the later stages of the advance when the ice over these sites was relatively thin or gone, but while the Lowland was still subjected to the load of some ice and a large lake.

There are two plausible mechanisns for loading the Cretaceous sediments in the basin to produce an overpressured zone which may have given rise to the mud volcanoes: (1) loading by the young Wrangell volcanic edifice and (2) loading by thick glacial ice and lake water. It is possible that either mechanism acting separately, or both acting together could have produced the mud volcanoes.

Implications of the mud volcanoes for geothermal exploration

Neither of the above mechanisms require a thermal drive to produce the mud volcanoes. It is therefore by no neans certain that any of the mud volcanoes represent a good target for geothermal energy exploration. However, the existence of significant helium anomalies at both groups and the preliminary geothermometry from Lower Klawasi (Motyka, in prep.) indicate a reasonable possibility that this mud volcano may possibly overlie a geothermal 
reservoir. In our preliminary report on the Copper River Basin, we recommended that adequate geophysical and geochenical surveys be carried out at Lower Klawas 1 to ascertain whether or not it represents a geothermal anomaly. We further recommended that a regional reconnaissance helium soil gas survey be carried out on the east side of the basin in order to ascertain whether or not significant helium anomalies are present in areas beyond the mud volcanoes (Turner and others, 1982). Helium aromalies can help to define target areas for additional geophysical and geochemical work aimed at discovering geothermal reservolrs.

\section{PREVIOUS GEOPHYSICAL AND GEOCHEMICAL SURVEYS}

The Copper River Basin has been the subject of geophysical surveys by various ofl companies, but these data are proprietary and are not available to us. The basin has been partially covered by aeromagnetic surveys. Andreasen and others $(1958,1964)$ reported on aeromagnetic coverage north from the Chugach Mountains to $63^{\circ} 00^{\prime} \mathrm{N}$ with eastern and western boundaries of longitude $145^{\circ} 00^{\prime} \mathrm{W}$ and $147^{\circ} 20^{\prime} \mathrm{W}$ respectively. This area includes the Tolsona group and Lower Klawasi. Upper Klawas 1 and Shrub mud volcanoes are just outside this coverage.

There is a negative 44 gamma anonaly at Lower Klawasi mud volcano, elongated in the direction of Shrub. Although Shrub is off the edge of the aeromagnetic coverage it almost certainly is in an area of steep magnetic gradient. Upper Klawasi on the other hand is in an area of gentle gradient. The USGS has done gravity mapping in the Copper River Basin. A 5 mgal contour map based on a survey by D.F. Barnes and others in 1958-60 has been published (Andreasen and others, 1964). A map with additional gravity values has also been supplied to us (D.F. Barnes, personal commun., 1981). There are many gaps in the coverage. W. Isherwood (personal commun., 1981) has made a 
fairly detailed gravity survey (223 stations) of the Mt. Drum area extending out to include the Klawasi mud volcaroes. The data have been made available to us in the form of computer printovts and $2 \mathrm{mgal}$ simple Bouguer and terrain corrected Bouguer gravity anomaly maps. The station density in the vicinity of the Klawasi mud volcanoes is about $1 \mathrm{station}$ per $7 \mathrm{sq} \mathrm{mi}$. Isherwood's corrected Bouguer anomaly values have been plotted and contoured at 1 mgal intervals as shown in Figure 1-4 for the vicinity of the Klawasi group. There are insufficient stations northeast of Shrub to warrant contouring. There is an obvious regional gradient due to Mt. Drum. The heavy contour lines are the residuals after the regional gradient was removed graphically. There appears to be a negative 3-4 mgal anomaly centered in the triangle formed by Lower Klawasi, Shrub, and Upper Klawasi. More detailed gravity surveys at 1 station per sq $m i$ in the area should make the relationship of these anomalies to the mud volcanoes or a geothermal system clearer.

Andreasen and others (1964) have discussed in detail their geologic interpretation of the magnetic and gravity data in the Copper River Basin. The area including the Klawasi group has been called the Mt. Drum magnetic anomaly pattern. The pattern consists of a fanlike group of magnetic anomalies that project from the east edge of the surveyed area. They interpret the magnetic pattern "to be produced by andesitic lavas from the now extinct and dissected Mt. Drum volcanic cone." They considered the anomalies within the pattern to be unsuitable for quantitative depth analysis, but suggested that steep magnetic gradients in the center near the edge of the surveyed area near and north of Shrub indicate that lavas there are at or near the ground surface. They suggest a depth to the lavas of perhaps 500 ft near the rim of the pattern, that is under Gulkana and Gakona. However, volcanic flows were not encountered in the AMOCO Ahtna wells discussed previously. 

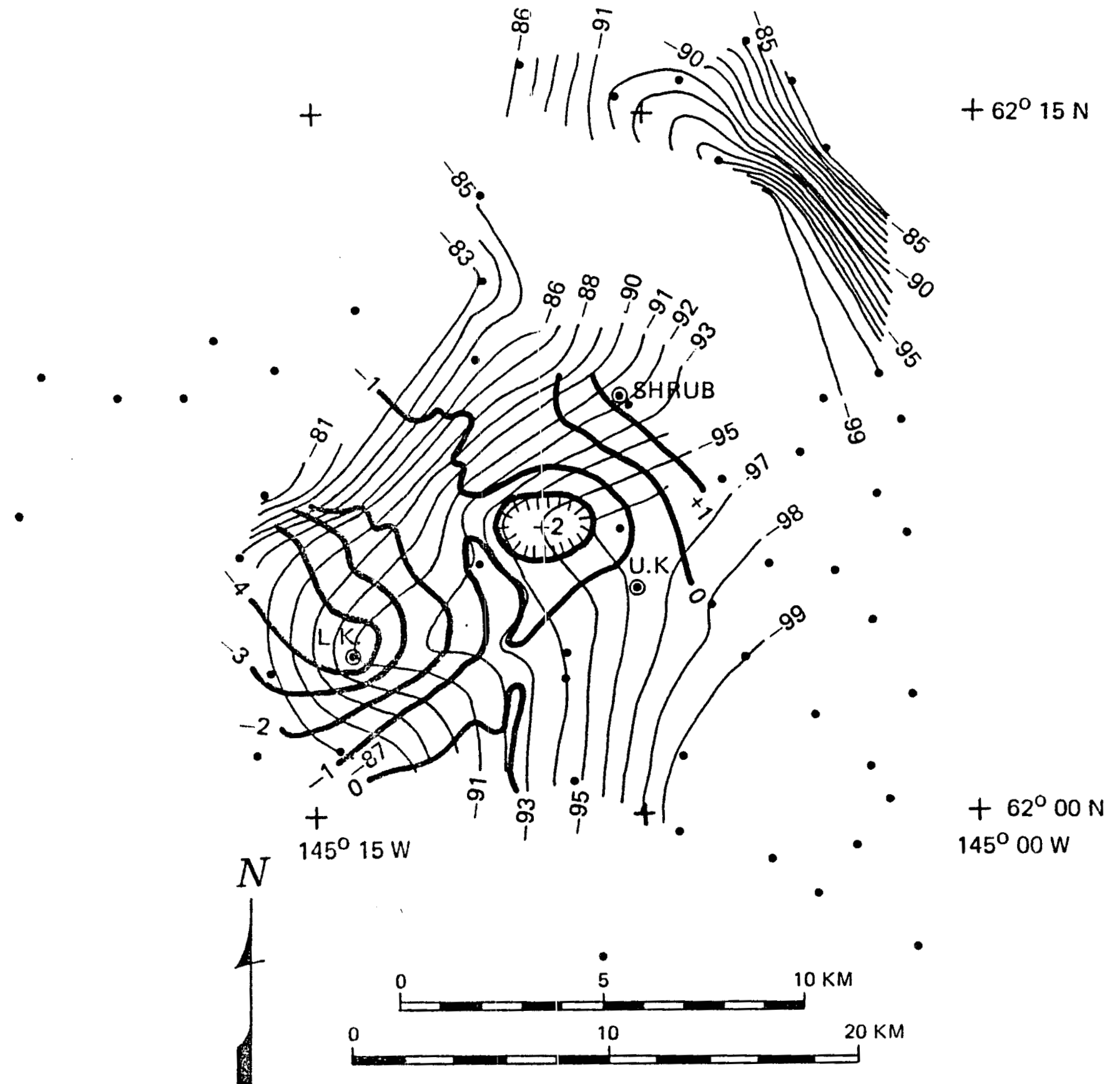

Figure 1-4. Complete Bouguer anomaly map from data by B. Isherwood (personal communication, 1981). The thin lines are 1 mgal contours, thick lines are residual gravity contours after renoval of regional gravity. Dots show stations (about one per 12 square miles). ilud volcanoes, lower Klawasi (L.K.), Upper Klawasi (U.K.) and Shrub are shown. ilote the 3-4 mgal negative anomaly at Lower KTawasi and the 2-3 mgal negative anomaly near the center of the triangle formed by Shrub and Upper and Lower Klawasi mud volcanoes. 
Andreasen and others (1964) interpret the gravity anomalies on the simple Bouguer anomaly map as suggesting that structures within the basin probably extend over the Wrangell Mountains where they are buried by Cenozoic lavas. All the gravity gradients associated with the Mt. Drum pattern are small, suggesting deep or gently sloping structures.

Andreasen and others (1964) measured the densities of some Copper River Basin rock units as given in Table $1-4$ below.

Table 1-4. Densities of Copper River Basin rock units, in grams per cubic centimeter.

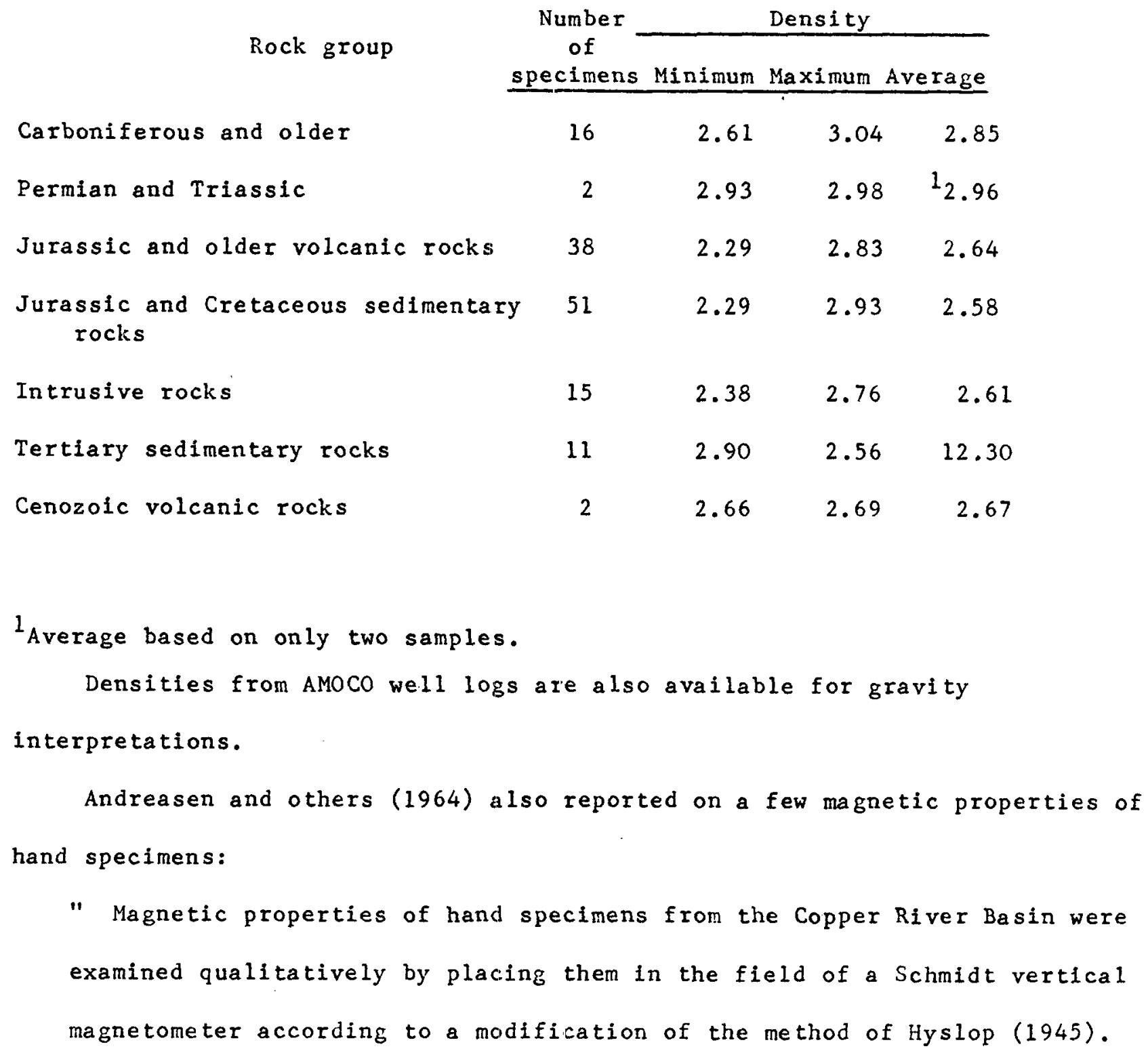


The induced magnetization exceeded the remanent magnetization of all except a few specimens of Jurassic and Carboniferous volcanic rocks and of Middle Jurassic sandstone containing local concentrations of magnetite. Strong remanent magnetism is present in more parts of the Talkeetna Formation than in any other rock in the surveyed area, and magnetic susceptibility measurements for this formation also showed a wide range (from less than 0.0001 to more than 0.1 cgs unit). However, high values and a wide range of magnetic susceptibility are also found in many specimens of Paleozoic volcanic rocks, intrusive rocks, and Tertiary volcanic rocks. Almost all spectmens of Jurassic and Cretaceous marine and Tertiary continental sedimentary rocks have susceptibilities below 0.005 and values below 0.001 predominate."

More samples measured quantitatively are needed to make model calculations of the magnetic anomalies.

Well logs of various sorts are available from the petroleum and gas exploration wells which have been drilled on public land in the basin, as discussed under 'Stratigraphy.' The well logs and driller's log from Pan American Petroleum Co. Moose Creek No. 1 well Sec. 29, T4N, R3W, CR meridian are most informative. From $5,277 \mathrm{ft}$ to $5,517 \mathrm{ft}$ they encountered a high pressured zone which yielded artesian salt water and methane gas. There were also indications of tar in the section. As discussed by Foresman (1970), this overpressured zone is proposed as the source of the mud volcanoes. The theory appears to be most appropriate for the Tolsona group which lie about 4 mi west of the we11.

The gases emanating from the Tolsona group are rich in methane (Reitsema, 1979). He suggests the Cretaceous Nelchina Formation as the likely source of the methane. This is consistent with the overpressured zone providing the 
energy for the eruptions. No source of heat is required to drive them. This explanation would also fit the Nickel Creek mud volcano and a spring $7.5 \mathrm{~km}$ south-southwest of Lower Klawasi mud volcano.

The gas from Tolsona group of mud volcanoes is also anomalously high in helium, ranging from 612 to $1,775 \mathrm{ppn}$. If the source of the methane is the overpressured zone in the Nelchina Formation, the gas reservoir might serve as a trap for helium as well. The logs indicate a thick section of shale overlying the overpressured zone which might serve as an effective cap for both methane and helium. If so, the high helium might not indicate a geothermal source for the water flowing from these cones.

The Klawasi'group, however, is quite different. The gases are about 99.5 percent $\mathrm{CO}_{2}$ with a helium content of 97 to $258 \mathrm{ppm}$. The helium content is anomalous with respect to the atmospheric value of $5.24 \mathrm{ppm}$ but the signiflcant parameter of the flux of helium through the soil is unknown for comparison with known geothermal areas. Soil gas measurements as a function of distance from the mud volcanoes could allow an assessment of the importance of helium concentration as an indicator of geothermal resources. 
REFERIENCES CITED

Andreasen, G.E., Grantz, Arthur, Zietz, Isadore, Barnes, D.F., 1964, Geologic interpretation of magnetic and gravity data in the Copper River basin, Alaska: U.S. Geological Survey Professional Paper 316-H, p. 135-153.

Benson, C.S., and Motyka, R.J., 1979, Glacier-volcano interactions on Mt. Wrangel1, Alaska: Fairbanks, University of Alaska, 1977-1978 Annual Report, p. 1-25.

Corwin, R.F., and Hoover, D.B., 1979, The self-potential method of geothermal exploration: Geophysics, v. 44, no. 2, p. 226-245.

, 1970, Mud volcanoes and abnormal pressure, Copper River basin, Alaska: University of Tulsa, M.S. thesis, $39 \mathrm{p}$.

Grantz, Arthur, White, D.E., Whitehead, H.C., and Tagg, A.R., 1962, Saline springs, Copper River lowland, Alaska: American Association of Petroleum Geologists Bulletin, v. 46, no. 11, p. 1990-2002.

Hyslop, R.C., 1945, A field method for determining the magnetic susceptibility of rocks: AIME Transactions, v. 154, p. 242-246.

Jones, D.L., Solberling, N.J., and Hillhouse, J., 1977, Wrangellia - a displaced terrain in northwestern North America: Canadian Journal of Earth Science, v. 14, no. 11, p. 2565-2577.

, 1905, Geology of the central Copper River region, Alaska: U.S. Geological Survey Professional Paper 4l, $133 \mathrm{p}$.

Miller, D.J., Payne, T.G., and Gryc, Ceorge, 1959, Geology of possible petroleum provinces of Alaska: U.S. Geological Survey Bulletin 1094 , $131 \mathrm{p}$.

Motyka, R.J., Mackeith, P., and Benson, C.S., 1980, Mt. Wrangell caldera: Utilization of glacier ice to measure heat flow and infer thermal regime, v. 61 , no. 6, p. 69 .

Nichols, D.R., and Yehle, L.A., 1961, Highway construction and maintenance problems in permafrost regions, in Proceedings, 12 th Annual symposium on Geology as applied to Highway Engineering: University of Tennessee Engineering Experiment Station Bulletin 24, p. 19-29.

, 1961, Mud volcanoes in the Copper River basin, Alaska, in Raasch, G.0., ed., Geology of the arctic: Toronto, University of Toronto Press, v. 2, p. 1063-1087.

Nichols, D.R., and Yehle, L.A., 1980, Reconnaissance map and description of the Chetaslina volcanic debris flow (new name), SW Copper River basin and adjacent areas, south-central Alaska: U.S. Geological Survey

Miscellaneous Field Studies Map MF-1209, scale 1:250,000, Map MF-1209. 
Reitsema, R. H., 1979, Gases of mud volcanoes in the Copper River Basin, Alaska: Geochimica et Cosmochimica Acta, v. 43, p. 183-187.

Richter, D.H., Smith, R.L., Yehle, L.A., and Miller, T.P., 1979, Geologic map of the Gulkana A-2 Quadrangle, Alaska: U.S. Geological Survey Geologic Map GQ 1520 , scale $1: 63,360$.

Richter, D.H., Strith, R.L., 1976, Geologic map of the Nabesna A-5 Quadrangle, Alaska: U.S. Geological Survey Geologic Quadrangle Map GQ-1520, scale $1: 63,360$.

Smith, R.I., and Shaw, H.R., 1979, Igneous-related geothermal systems, in Muffler, L.J.P., ed., Assessment of geothermal resources of the United States, 1978: U.S. Geological Survey Circular 790, p. 12-17.

Turner, D.L., Wescott, E.M., and Nye, C.J., 1982, Summary of geologic geochemical and geophysical data relevant to geothermal energy exploration in the eastern Copper River basin, Alaska: Preliminary report to Alaska Division of Geological and Geophysical Surveys for RSA $82-5 X-670,47$ p. 
CHAPTER 2

\author{
1982 and 1984 Helium Soil Survey Results in the Eastern \\ Copper River Basin, Alaska \\ by
}

Donald L. Turner and Eugene M. Wescott

\title{
Characteristics and Sources of Helium
}

Helium is the second lightest known element with a density of 0.1381 grams/liter (hydrogen is 0.0695 and air is 1). It has a molecular and atomic weight of 4 and is an inert, elemental gas with no known chemical compounds. Helium's low solubility in cold water, monatomic molecular structure, low cross-section capture coefficient, extremely light weight, chemical inertness and high diffusivity give it a unique advantage over other geochemical trace elements in that heliun will always migrate from its source to the surface of the earth.

Helium is steadily generated by radjoactive elements in rocks and minerals. This occurs when alpha particles (released by decay in the uranium and thorium isotope series) capture two electrons to form atoms of inert helium. Other sources of helium on earth, such as those due to primordial accumulations, cosmic radiation, meteorites, radioactive tritium decay, etc., do not contribute significantly to the total annual production.

Helium production differs considerably in different rock types due to variable uranium and thorium content. Anomalous concentrations of helium in soil gases have been found over radioactive ore bodies (Dyck, 1976). This source of surface helium flux non-uniformity is unlikely to be of importance in the Copper River Basin.

Helium loss to the atmosphere is only about five percent of its rate of production, indicating that most of the helium produced is trapped 
within the earth in various ways. Helium movement through the geologic column is a complex combination of fluia transport and gaseous diffusion. Studies have shown that the distance helium moves by diffusion is several orders of magnitude smaller than the distance moved in equal time by fluid transport.

Most petroleum reservoirs in the United States have significant concentrations of helium - greater than 100 parts per million (Dyck, 1976). Helium tends to migrate into traps that contain natural gas (methane). Leakage of helium from these traps will tend to produce nonuniform distributions of helium flux at the surface. For instance, helium would tend to leak around the edges of an impermeable cap rock and form anomalous concentrations around the cap outline (Pogorski and Quirt, 1981). Permeable faults in proximity to gas traps would also serve as escape routes for helium. These sources of helium anomaly patterns are possible in a sedimentary basin such as the Copper River Basin and must be carefully considered in interpreting the results of our helium survey.

Helium is very unusual in that its solubility in water increases with temperature above $30^{\circ} \mathrm{C}$ (Figure 2-1 after Mazor, 1972). In a geothermal system, pressurized hot water will therefore be a very efficient scavenger of helium produced by radioactive decay of uranium and thorium contained in the rocks at depth. This scavenged helium will be released as the heated water rises towards the surface, cools and depressurizes. Since helium is highly mobile it will seek faults, fractures and pore spaces to rise to the surface above the geothermal system. Figure 2-2 is a schematic diagram showing how a geothermal reservoir acts as a local source of helium. Figure 2-3 illustrates that faults provide an easy path for helium as well as rising hot water (Figures after Pogorski and 

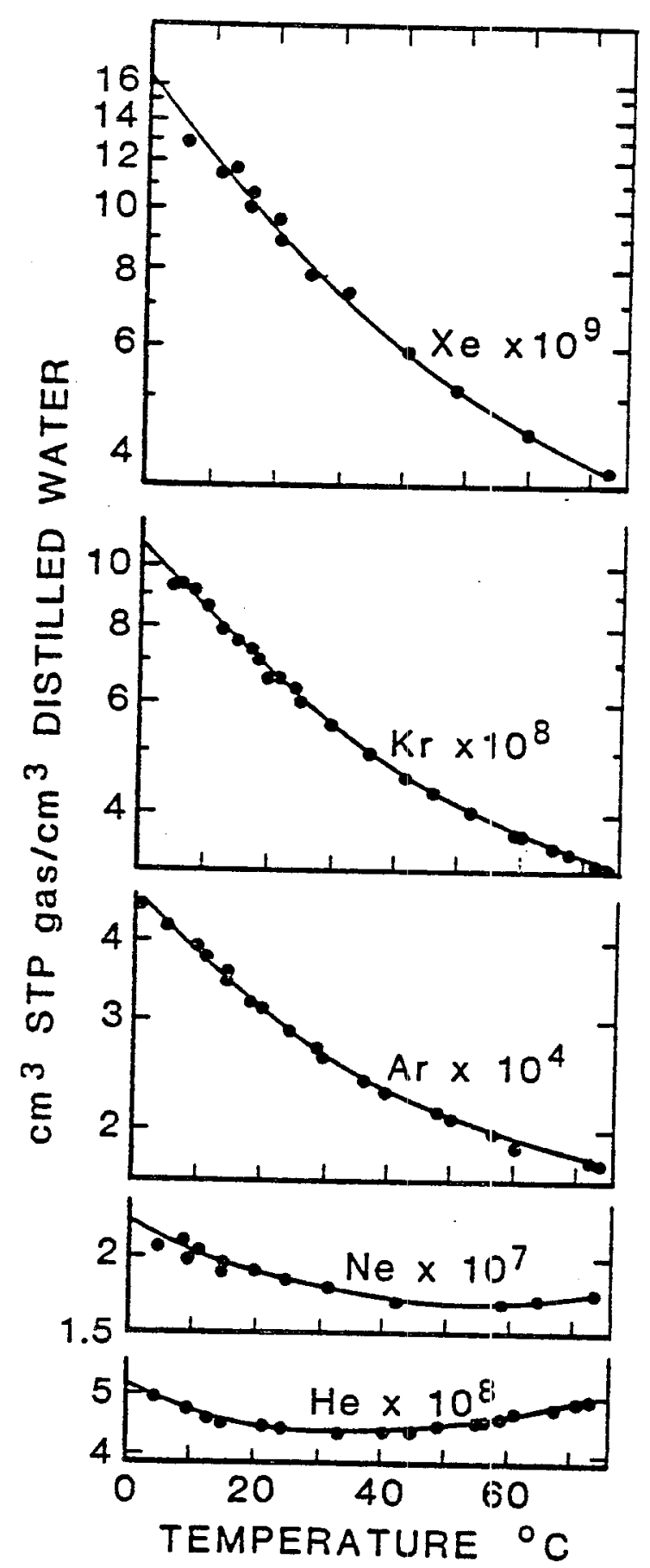

Figure 2-1. Solubility of noble gases in fresh water (after Mazor, 1972). 


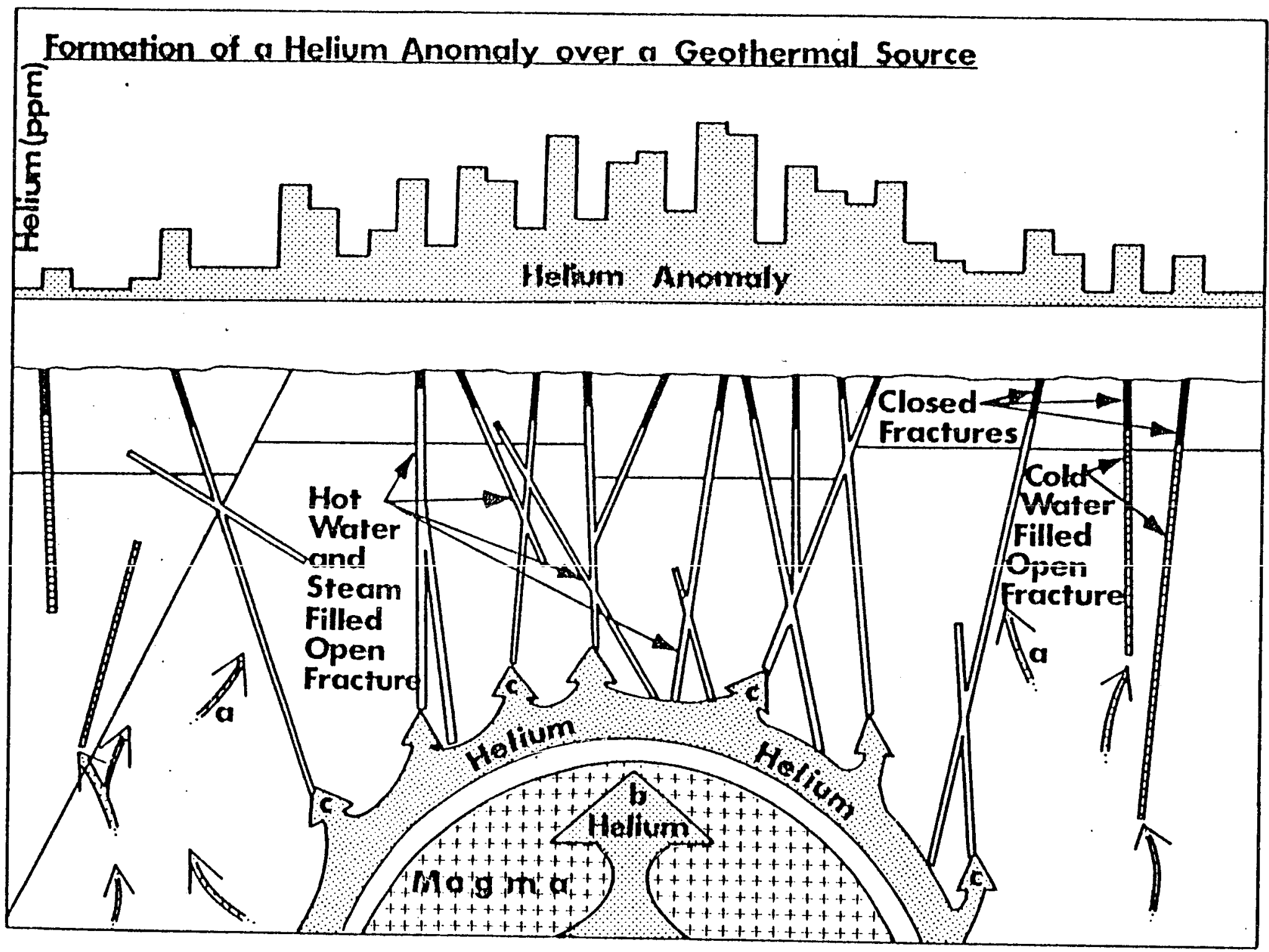

Figure 2-2. A schematic diagram illustrating that a geothermal reservoir acts as a local source of helium. In this diagram there are three sources of helium: (a) helium from the background flux; (b) helium from the magma heat source; and (c) helium scavenged by the hot geothermal waters. From Pogorski and Quirt (1981). 


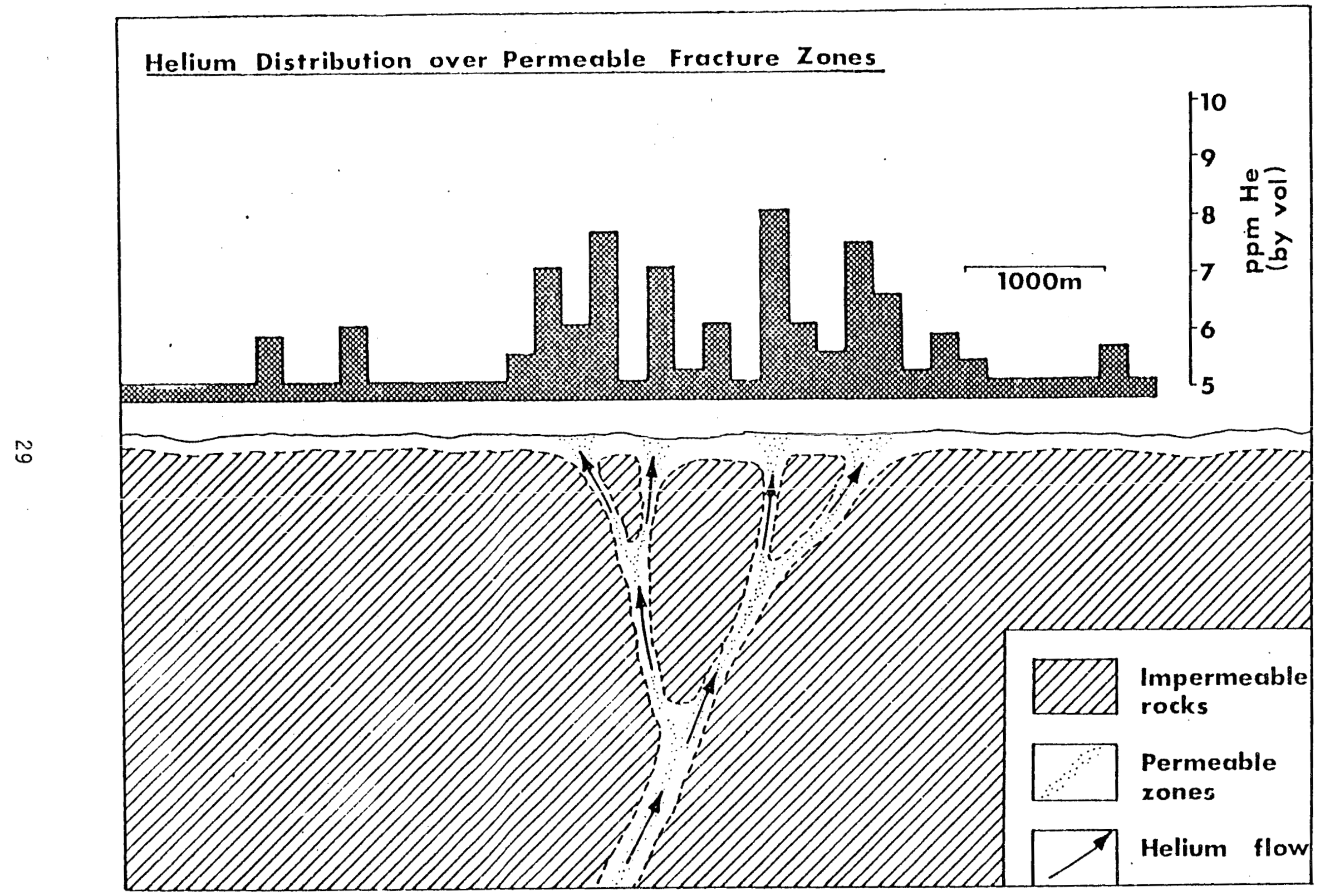

Figure 2-3. A schematic diagram illustrating that faults provide an easy path for helium migration from depth. From Pogorski and Quirt (1981). 
Quirt, 1981).

The ability of helium to migrate away from its ultimate source of radioactive rocks and to accompany geothermal systems provides a convenient geochemical tracer. In fact it appears that helium might even be considered a direct indicator for geothermal reservoirs since elevated levels of helium are observed at most geothermal sites (see Appendix and References).

\section{Exploration Techniques}

Helium surveys have been developed and perfected as a time-and-costeffective geothermal exploration method. The ability of helium to migrate long distances through the geclogic column creates largehalo helium anomalies which can be defined by water, soil and soil-gas sampling.

In addition tö helium, many other techniques are used for outlining geothermal resource areas. The most common approach has been surface heat flow mapping (not too reliable for deep reservoirs) and borehole temperature profiling (expensive). These temperature methods are not generally used in an initial exploration phase, but rather as follow-ups to discoveries of hot springs, volcanic areas and subsurface (drill hole) temperature anomalies. Other techniques which have proved useful are isotope ratioing, chemical thermometry, surface/subsurface alteration studies, microearthquake monitoring and electrical surveying (e.g., resistivity and self-potential).

However, when the heat source is deeply buried, e.g. in broad basins with insulating sedimentary rock layers, many of these exploration methods can be costly and prohibitively time consuming. Helium surveys provide a rapid sampling technique that can be usel with minimum effort and at very 
low cost. Samples can be collected as water, soil or soil gas and then analyzed for helium to better than 10 parts per billion in the gaseous sample by mass spectrometry. It is this precise analytical capability that only recently has permitted helium to be utilized as an effective trace element in geothermal exploration.

Due to helium's ability to escape from a geothermal system at depth, anomalies will be noted above fractures connected to the geothermal reservoir. This may be the only identifiable indicator, since precipitated calcite and silica may have effectively sealed the reservoir and prevented heavier elements from reaching the surface. Although there may be an active reservoir at depth, near surface temperature anomalies may be slight or even non-existent.

Positive temperature anomalies will usually coincide with helium anomalies, although there may be some off'set e.g. Appendix A, Figure 1. This is a very significant correlation and gives the geothermal explorationist an additional method with which to define optimum drill sites for reservoir confirmation.

Regional helium surveys generally require a sample density of one to five samples per square mile. Detailed exploration is usually conducted with a 0.1 mile grid spacing, which can be followed up with sample spacing of 50 to $100 \mathrm{ft}$ in the most anomalous zones. If an elongate reservoir is expected (such as a rift or parallel felult/fracture zone) the grid can be modified accordingly.

\section{Sampling Methods}

Figure 2-4 (after Pogorski and Quirt, 1981) illustrates how helium occurs in soil, and indicates how it can be sampled. We sample the soil for 


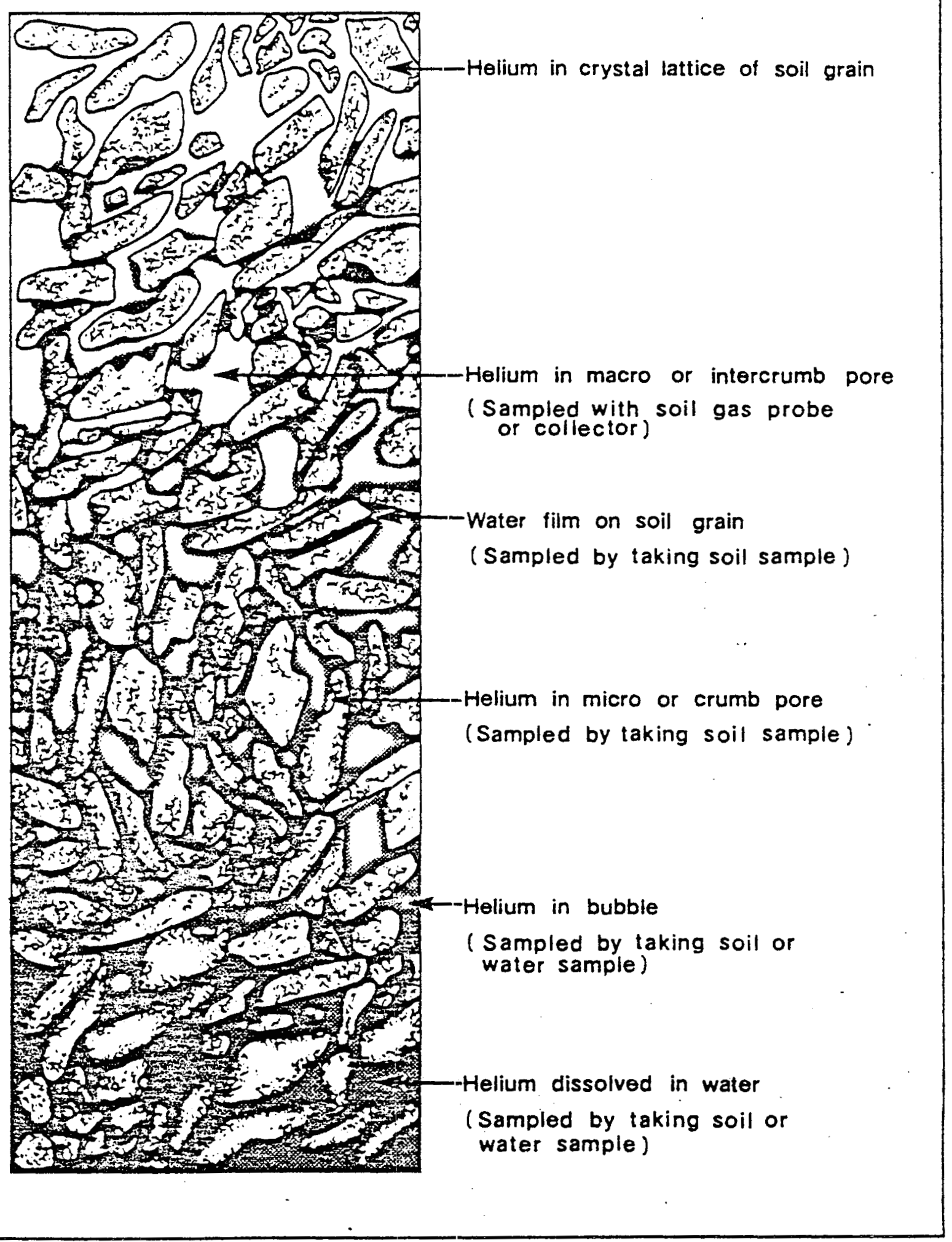

Figure 2-4. Schematic diagram showing how helium occurs in soil. From Pogorski and Quirt (1981). 
helium in two ways: when the soil is dry and permeable, we drive a probe $3 \mathrm{ft}$ into the ground and draw off a soil gas sample which is then inserted into a small evacuated steel ampule with a syringe and sealed for later analysis. This method does not work well in wet soil or where the soil is rocky or frozen. In such conditions we use a soil auger to drill a hole as close to 3-ft depth as possible. The soil core from the bottom of the hole is then quickly placed in a steel food can and sealed with a portable canner. Special aluminum containers and container sealers have also been developed for this purpose by Chemical Projects Ltd., Toronto, Canada.

Water in lakes and ponds below the thermocline can also be sampled for helium by collecting the water in a special bottle with a known fraction of air, shaking the sealed bottle to exsolve the helium, and drawing off a gas sample with a syringe. The gas in the syringe is then inserted into the same evacuated ampules used for soil gas, as described above.

We attempted to take helium samples on a one mile grid spacing, but lack of helicopter landing areas prevented sampling in many locations. Closer spaced sampling was done in areas of special interest, e.g., mud volcanoes and areas where our initial sampling produced positive results.

Permafrost was encountered in a large proportion of the sampling sites and the soil auger could generally not be driven to the desired $3 \mathrm{ft}$ depth. Because of this problem, frozen soil cores were generally taken from only 1 to $2 \mathrm{ft}$ depths. However, the many anomalously high helium results from holes ranging in depth from 0.5 to $1.5 \mathrm{ft}$ (Table 2-1) indicate that shallow soil cores in frozen ground yield acceptable samples for helium analysis. Roberts (1981) also reported on helium surveys in 
Table 1. Calculated concentrations of helium in water-saturated soils

\begin{tabular}{|c|c|}
\hline Sample Number & $\mathrm{cc} \mathrm{He} / \mathrm{cc} \mathrm{H}_{2} \mathrm{O}$ \\
\hline C84GG10 & $7.05 \times 10^{-8}$ \\
\hline C84G11 & $1.53 \times 10^{-7}$ \\
\hline $\mathrm{C} 84 \mathrm{GI} 9 \mathrm{~B}$ & $6.03 \times 10^{-8}$ \\
\hline $\mathrm{C} 84 \mathrm{G} 23 \mathrm{~A}$ & $6.37 \times 10^{-8}$ \\
\hline C84GG41 & $3.82 \times 10^{-7}$ \\
\hline $\mathrm{C} 84 \mathrm{GG} 43$ & $2.36 \times 10^{-7}$ \\
\hline C84GG46 & $-5.66 \times 10^{-8}$ \\
\hline C84G52 & $6.43 \times 10^{-7}$ \\
\hline C84G53 & $1.64 \times 10^{-7}$ \\
\hline C84G57 & $5.06 \times 10^{-8}$ \\
\hline C84G59 & $4.27 \times 10^{-7}$ \\
\hline C84G61 & $3.04 \times 10^{-7}$ \\
\hline C84G62 & $-2.07 \times 10^{-7}$ \\
\hline$C 84 G 67$ & $2.98 \times 10^{-8}$ \\
\hline $\mathrm{C} 84 \mathrm{~T} 69 \mathrm{~B}$ & $7.84 \times 10^{-8}$ \\
\hline $\mathrm{C} 84 \mathrm{~T} 70$ & $7.84 \times 10^{-8}$ \\
\hline $\mathrm{C} 84 \mathrm{G} 74$ & $-2.44 \times 10^{-8}$ \\
\hline
\end{tabular}


permafrost areas of Alaska's north slope, and found good results sampling the permafrost.

Results

Three different, complimentary datia sets are discussed in this section:

1) 1982 helium soil, soil gas and water samples analyzed by Hexco International of Morrison, Colorado;

2) 1984 helium soil survey samples antyzed by the U.S. Geological Survey (U.S.G.S.), Denver; and

3) 1984 helium soil survey duplicate samples analyzed by Chemical Projects Ltd. of Toronto.

The 1982 survey data are reported es raw helium concentrations per unit volume of sample container headspace. For the 1984 survey, recently developed correction algorithms have been applied in order to convert raw headspace helium values in the sample containers to concentrations of helium in original gaseous soil pore space. Two approaches have been utilized for these corrections. One has been developed on a proprietary basis by Chemical Projects Ltd. It involves analysis and correction for various organic gases, as well as sample locality barometric pressure, air and soil temperatures, and sampling depths. This method was applied to 45 soil sample splits. The Chemical Projects Ltd. report on these results is included here as Appendix. B. Duplicate splits of these same samples were also analyzed by the U.S.G.S. (results to be discussed later).

A second approach to correcting raw helium container headspace concentration data has been developed by Kim R. Green (1984) in collaboration with Alan Roberts and Michael Reimer at the U.S.G.S., Denver, Branches of Oil and Gas, and Isotope Geology, respectively. We established a cooperative program with these workers in 1984 to further refine the correction 
procedures, and to evaluate the suitabjlity of ordinary metal food cans as helium soil survey containers. The details of these correction procedures (Green, 1984) are complex and need not be discussed here. Chapter 3 explains their applicetion to the 1984 survey U.S.G.S.analyzed data and reports the positive results of the metal food can study. Although differing in quantitative helium values, the $1982 \mathrm{Hexco}$, 1984 U.S.G.S. and 1984 Chemical Projects Ltd. results all gave helium anomalies in the same areas of the Copper River basin study area, as shown on Plates $1-3$. 1982 Survey Results

A total of 144 samples were collected in 1982. Of these 113 were soil, 28 were soil gas and 3 were water. Mass spectrometric analyses for He-4 were performed by Hexco International to a precision of $10 \mathrm{ppb}$. Helium concentrations were reported as raw (uncorrected) container headspace values and no analyses were made for organic gases. Sample locations are shown on Plate 1. Helium values for each sample are given in Table 2-1.

The number of helium anomalies is surprisingly high, with $25 \%$ of the samples having $>5.4 \mathrm{ppm}$ (normal atmospheric concentration is $5.24 \mathrm{ppm}$ ). Plate 1 shows several areas of anomalously high helium. There are definite, intervening areas of normal helium soil gas values (open circles) indicating a nonuniform source of the helium.

A number of helium concentration values below the atmospheric concentration of $5.24 \mathrm{ppm}$ (Table $2-1$ ) are believed to result from other gases such as methane and $\mathrm{CO}_{2}$ diluting the helium gas fraction. In drawing the helium anomaly patterns of Flate 1, we have considered 
all values less than 5.24 to be equal to 5.24 . In fact, some may actually be greater than 5.24 but we could not determine the anomalous presence of other gases with our 1982 analyses techriques.

Reconnaissance helium surveying was continued along the highway to about 3 miles north of the Gulkana airport, but no additional positive anomalies were found. We also took three soil gas samples at Glennallen and one near Glennallen Lodge (Figure 2-5) with negative results. A significant helium soil gas anomaly was found at the Tolsona No. 2 mud volcano (Figure 2-5), consistent with the high helium flux reported by previous workers and discussed in Chapter 1.

\section{Survey Results}

In 1984, we expanded on the results of the 1982 survey by collecting soil samples designed to 1) corroborate the 1982 helium anomaly areas (Plate 1) and better define their extent, and 2) fill in intervening areas as much as possible. Complete listings and analysis of the 1984 data and their correction procedures are given in Appendix B and Chapter 3. Plate 2 shows the distribution of samples analyzed by the U.S.G.S. and Plate 3 shows the distribution of the duplicate sample splits analyzed by Chemical Projects, Ltd.

Figure 2-6 is a correlation diagram comparing the duplicate 1984 soil sample splits analyzed separately by the U.S.G.S. and Chemical Projects, Itd. For a given locality, each sample was mixed at the collecting site on a plastic tray, split into two parts, and each split sealed in separate containers within one minute of each other. Special, proprietary aluminum containers were used for the sample splits sent to Chemical Projects, Ltd.

About half of the samples plot on or near the $1: 1$ correlation line 

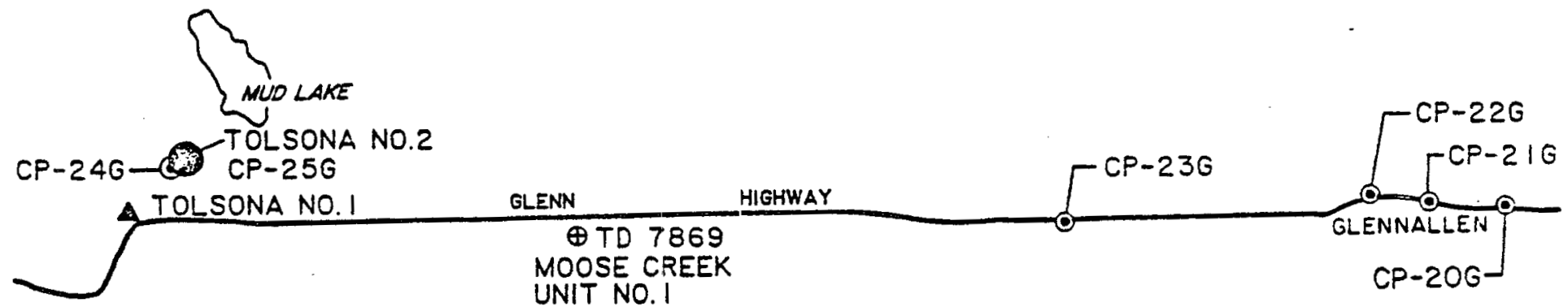

(3)

0

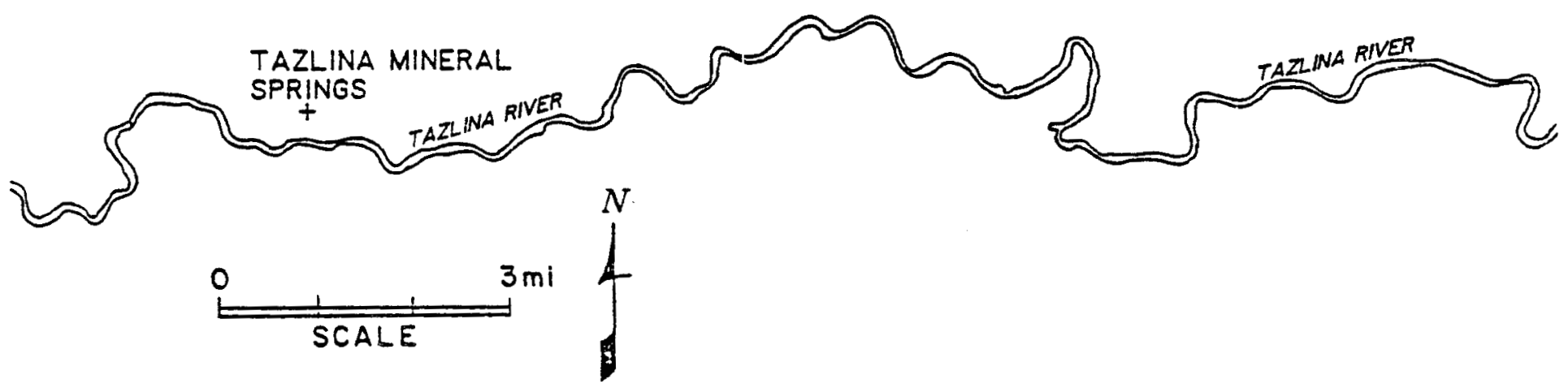

Figure 2-5. Hel ium soil gas samples along the Glenn Highway. Large black dot $=9.15 \mathrm{ppm}$. Open circles are normal background values. Samples $20-22 \mathrm{G}$ taken in town of Glennallen. 


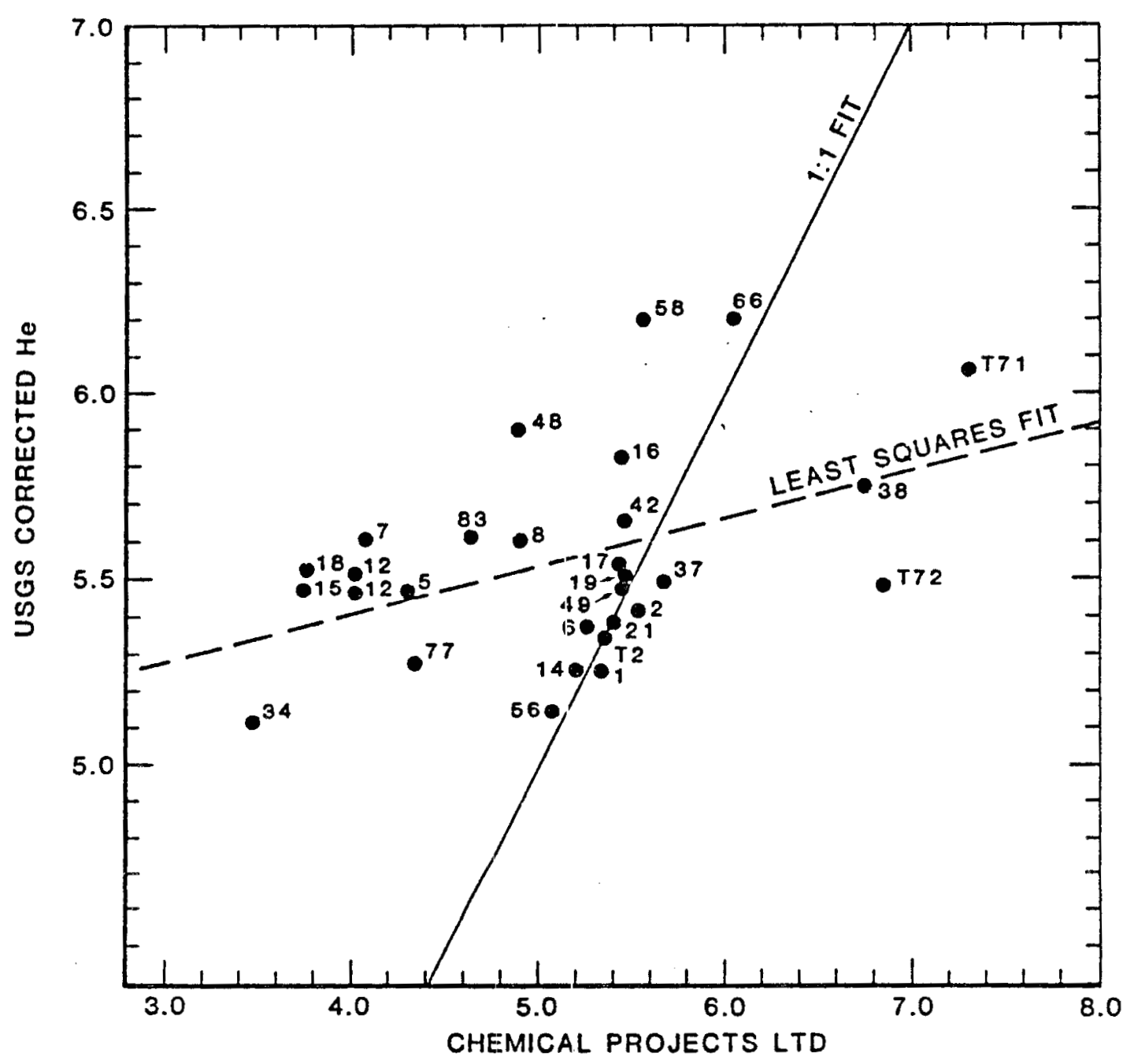

Figure 2-6. Correlation diagram comparing duplicate 1984 soll samples analyzed separately by the U.S.G.S. and Chemical Projects Ltd. Values in ppm He. Poor correlation is believed to be due to lack of correction for organic gas content in U.S.G.S. samples. 
of Figure 2-6. Of those that plot well away from this line, most are high in propane and propene (Appendix B), suggesting that analysis of organic gas components, as practiced routinely by Chemical Projects, Ltd, is necessary for the determination of valid correction factors to determine helium in gaseous pore space in the original soil. Soil Hydrocarbon Studies

The Chemical Projects Ltd. He analyses included the light hydrocarbons: methane, ethane, ethene and combined propane and propene (Appendix B). Light hydrocarbons in soil may be due to microbiological activity either before the soil was canned, or afterwards when the sample was raised to a higher temperature. In some cases, these hydrocarbons may also indicate the presence of an oil or gas accumulation at depth.

Most of the samples from the Klawasi area were low in hydrocarbons, but many of the samples from the Tazlina area had relatively high values of propane and propene (Appendix B). We thought at first this might indicate an interesting oil and gas prospect. However, discussions with an expert in soil hydrocarbons ( $\mathrm{Dr}$. Leo Horwitz, per. comm.) convinced us that the light hydrocarbons were probably due to microbiological activity. Most oil and gas fields show light hydrocarbons in soil samples. But almost always there is a monotonic decrease in hydrocarbon concentration with molecular weight. That is, there should be more methane than ethane, more ethane than propane, etc. The fact that most of our samples have no ethane, but have propane plus propene concentrations equal to the methane concentration, is indicative of a biological origin.

A natural gas or petroleum accumulation under the Tazlina area cannot be totally ruled out by these preliminary results, but additional analyses of absorbed gases would be required for a more definitive study. 
$\underline{\text { Summary and Conclusions }}$

Regardless of individual numerical differences in helium concentrations, our three separate sets of helium soil gas data (1982 Hexco uncorrected, 1984 USGS and 1984 Chemical Projects, Ltd.) all give anomalies in the same areas. This result may be seen most clearly by comparing Plates 1 , 2 and 3. In addition, the 1984 survey has considerably expanded the helium anomaly areas. Plate 2 shows these expanded anomalous areas which represent the combination of all anomalous localit:les from both the 1982 and 1984 surveys, using all three data sets.

The several areas of anomalously high helium are consistent with the hypothesis that these areas could be underlain by geothermal reservoirs. Although helium anomalies do not in themselves constitute proof of a geothermal source, the fact that several of the major anomaly areas are coincident with other geophysical ancmalies could possibly suggest a relationship to geothermal sources. This will be discussed more fully in the final chapter of this report.

Three hypothetical linear distributions of helium anomaly areas, labelled Lin. 1, 2 and 3, are shown on Plate 1. These hypothetical linears may be possibly significant in that they appear to connect many of the helium anomalies in the area, as well as the mud volcanoes and a mineral spring. One reasonable working hypothesis is that one or more of these linears may represent subsurface faults which serve as conduits for helium along portions of their lengths. This hypothesis would also provide the necessary zones of weakness for upwelling water and mud required to produce the mud volcanoes and the Copper Center mineral spring (Plate 1). The proposed linears do not have any known surface expressions. They are, however, parallel to the long gravity trough that 
extends northeast across the area (see gravity chapter). Our examination of oil company sejsmic data in the Copper River basin indicates that the structure of this area is characterized by a number of northeast-trending normal and high-angle reverse faults. These results are proprietary and cannot be ciscussed in further detail here. Because of this seismic evidence, we believe that the bulk of the available data favors the hypothesis that helium is reaching the surface through fault-controlled conduit systems. Whether these conduits also carry geothermal waters or not has not been proved. The relationship of the helium anomaly areas to geophysical anomalies and the implications of these coincident geochemical and geophysical anomalies for geothermal resource assessment will be discussed in the final chapter of this report. 
References on the Use of Helium in Geochemical Exploration

Bagirov, V. I. et al. 1976, Developing Geochemical Methods for Marine Exploration of $0 i l$ and Gas: International Geology Review, v. 18, no. 5, pp. 560-562.

Ball, L. et al. 1979, The National Geothermal Exploration Technology Program: Geophysics, v. 44, no. 10, pp. 1721-1737.

Ball, N. L. and Snowdon, I. R., 1973, A Preliminary Evaluation of the Applicability of the Helium Survey Technique to Prospecting for Petroleum: Geological Survey of Canada, paper 73-1B, pp. 199-202.

Bergquist, L. E., 1980. Helium Emanometry, an Energy Exploration Guide: Fiftieth Annual International Meeting and Exposition, Society of Exploration Geophysicists, Houston, Technical Papers, v. 5, pp. 2567-2578.

Bergquist, L. E., 1979, Helium, an Exploration Tool for Geothermal Sites: Transactions, Geothermal Resources Council, v. 3, pp. 59-60.

Bulashevich, Y. P. and Bashorin, V. N., 1973, On the Detection of Faults Along the Sverdlovsk DDS Profile from High Concentrations of Helium in Underground Water: IZV, Earth Fhysics, No. 3, 1973, pp. 185-189.

Cook, E., 1979, The Helium Question: Science, v. 206, no. 4423, pp. $1141-1147$.

Craig, H. et al. 1978, Helium Isotope Ratios in Yellowstone and Lassen Park Volcanic Gases: Geophysical Research Letters, v. 5, no. 11, pp. 897-900.

Denton, E. H., 1977, Helium Sniffer Field Test, Roosevelt Hot Springs, Utah: U.S. Geological Survey, Open-File Report 77-606, 6 p.

Denton, E. H., 1976, Helium Sniffer Field Test, Newcastle, Utah, 10-26 March, 1976: U.S. Geological Survey, Open-File Report 76-421, 4 p.

Dyck, W., 1976, The Use of Helium in Mineral Exploration: Journal of Geochemical Exploration, v. 5, no. 1, pp. 3-20.

Golubev, V. S. et al. 1970, Some Characteristics of Migration of Helium in the Permeable Systems of the Upper Part of the Earth's Crust: Translated from Geokhimiya, in Geochemistry International, 1970, pp. 943-950.

Green, K. R., 1984, An algorithm for determining soil and water helium concentrations from headspace analyses: Examples of geochemical applications in Long Valley, California, and the Fiji Islands, Colorado School of Mines M.S. Thesi.s, 197 p., 3 App. 
Gutsalo, L. K., 1976, On the Sources ard Distribution of Helium and Argon Isotopes in the Thermal Waters of the Kurile Islands and Kamchatka: Translated from Geokhimiya, no. 6, in Geochemistry International, v. 13, no. 3, pp. 167-175.

Gutsalo, L. K., 1976, On the Sources and Distribution of Helium and Argon Isotopes in the Thermal Waters of the Kurile Islands and Kamchatka: Geochemistry International, v. 13, no. 3, pp. 167-175.

Gutsalo, I. K., 1966, Importance of Groundwater Helium Saturation in Oil and Gas Prospecting: Translated (1970) from Izvestiya AN SSS, Ser. Geologicheskaya, 31 (9) 111-116 (1966), through University of California, UCRL-Trans-10483.

Hinkle, M. E., 1978, Helium, Mercury, Sulfur Compounds, and Carbon Dioxide in Soil Gases of the Puhimau Thermal Area, Hawail: U.S. Geological Survey, Open-File Report 78-246, 14 p.

Hinkle, M. E. et al. 1978, Helium in Soil Gases of the Roosevelt Hot Springs Known Geothermal Resource Area, Beaver County, Utah: Journal Research, U.S. Geological Survey, v. 6, no. 5, pp. 563-570.

Holland, P. W. and Emerson, D. E., 1979, Helium in Ground Water and Soil Gas in the Vicinity of Bush Dome Reservoir, Cliffside Field, Potter County, Texas: U.S. Department of the Interior, Bureau of Mines Information Circular IC $8807,22 \mathrm{p}$. (A Case History).

Hunt, J. M., 1979, Petroleum Geochemistry and Geology, Published by W. H. Freeman and Company, San Francisco, Calif., 617 p.

Levinson, A. A., 1974, Introduction to Bxploration Geochemistry, Published by Applied Pub. Co., Wilmette, Ill., 924 p.

Mast, R. F., 1978, U.S. Geological Survey Oil and Gas Resource Investigations Program, U.S. Geological Survey, Ojen-File Report 78-303, 81 p.

Mazor, E., 1977, Geothermal Tracing with Atmospheric and Radiogenic Noble Gases: Geothermics, v. 5, pp. 21-36.

Mazor, E. and Verhagen, B., 1976, Hot Springs of Rhodesia, Their Noble Gases, Isotopic and Chemical Composition: Journal of Hydrology, v. 28, pp. 29-43.

Mazor, E., 1975, Atmospheric and Radiogenic Noble Gases in Thermal Waters; Their Potential Application to Prospecting and Steam Production Studies: Proceedings, Second United Nations Symposium on the Development and Use of Geothermal Resources, pp. 793-802.

Mazor, E. and Fournier, R. 0., 1973, More on Noble Gases in Yellowstone National Park Hot Waters: Geochimica et Cosmochimica Acta, v. 37, pp. 515-525.

Mazor, E., 1972, Paleotemperatures and Cther Hydrological Parameters Deduced from Noble Gases Dissolved in Groundwaters; Jordan Rift Valley, Israel: Geochimica et Cosmochimica Acta, v. 36, pp. 1321-1336. 
Moore, C.A. and Esfandiari, B., 1971, Geochemistry and Geology of Helium: in Advances in Geophysics, v. 15, ppp. 1-57.

Naughton, J. J. et al. 1973, Heliurn Flux from the Earth's Mantle as Estimated from Hawaiian Fumerolic Degassing: Science, v. 180, pp. 55-57.

Nikonov, V. F., 1972, Formation of Helium - Bearing Gases and Trends in Prospecting for Them: Translated in International Geology Review (1973), v. 15, pp. 534-541.

Newton, R. and Round, G. F., 1961, The Diffusion of Helium through Sedimentary Rocks: Geochimica et Cosmochimica Acta, v. 22, pp. 106-132.

Palacas, J. P. and Roberts, A. A., 1980, Helium Anomaly in Surficial Deposits of South Florida, Possible Indicatior of Deep Subsurface Petroleum or Shallow Uranium-Associated Phosphate Deposits: U.S. Geological Survey, Open-File Report 80-91, 14 p. (A Case History).

Panchenko, A. S., 1974, Positive and Negative Gas Hydrochemical Halos and Their Significance for Oil and Gas Prospecting: Translated from Izvestiya AN SSSR, in International Geology Review, v, 16, no. 3, pp. 259-262.

Pierce, A. P. et al. 1964, Uranium and Helium in the Panhandle Gas Field, Texas and Adjacent Areas: U.S. Geological. Survey, Professional Paper 454-G, 56 p.

Pierce, A. P., 1960, Studies of Helium and Associated Natural Gases: U.S. Geological Survey Professional Paper 400-B, pp. B77-B79.

Pierce, A. P., 1955, Radon and Helium Studies: Geologic Investigations of Radioactive Deposits, Semi-Annual Frogress Report, U.S. Department of the Interior, TE1-540, pp. 233-237.

Pirson, S. J., 1969, Geological, Geophysical and Chemical Modifications of Sediments in the Environment of 0il Fields: in Unconventional Methods in Exploration for Petroleum and Natural Gas, Published by Southern Methodist University Press, Dallas, Texas, pp. 159-186.

Pogorski, L. A., and Quirt, G. S., 1981, Helium Emanometry for Hydrocarbons, Part I, in Unconventional Techniques in Exploration for Petroleum and Natural Gas, Southern University Press, Dallas, Texas, pp. 124-135.

Pray, H. A. et al. 1952, Solubility of Hydrogen, Oxygen, Nitrogen and Helium in Water at Elevated Temperatures: Industrial and Engineering Chemistry, v. 44, no. 5, pp. 1146-1151.

Reimer, G. M. et al. 1980, Helium Soil Gas Concentrations in the Torrington, Newcastle, Gillette (Wyoming) and Elcalaka (Montana) $1^{\circ} \times 2^{\circ}$ Quadrangles; Data from a Reconnaissance Survey: U.S. Geological Survey, Open-File Report 80-452, 14 p. plus 4 plates. (A Case History).

Riley, G. H., 1979, Helium Isotopes in Energy Exploration: Bulliton, Australia Society of Exploration Geophysicists, v. 10, no. 3, pp. 234-236. 
Roberts, A. A., 1979, Helium Emanometry for Hydrocarbons, II: in Unconventional Techniques in Exploration for Petroleum and Natural Gas, Southern Methodist University Press, Dallas, Texas. (A Case History), pp. 135-149.

Roberts, A. A. and Dalziel, M., 1976, A. Possible Petroleum Related Helium Anomaly in Soil Gas, Boulder and Counties, Colorado: U.S. Geological Survey, Open-File Report 76-544, 7 p. plus 3 plates. (A Case History),

Roberts, A. A. et al. 1975, Helium Survey, a Possible Technique for Locating Geothermal Reservoirs: Geophysical Research Letters, v. 2, no. 6, pp. 209-210.

Roberts, A. A. 1975, Helium Surveys Over Known Geothermal Resource Areas in the Imperial Valley, California: U.S. Geological Survey, OpenFile Report $75-427,6$ p.

Rosler, H. J. et al. 1977, Integrated Geochemical Exploration for Deep-Seated Solid and Gaseous Mineral Resources: Journal of Geochemical Exploration, v. 8 , no. 1 \& 2 , pp. 415-429.

Thomas, D. M. and Naughton, J. J., 1979, Helium/Carbon Dioxide Ratios as Premonitors of Volcanic Activity: icience, v. 204, pp. 1195-1196.

Tiratsoo, E. N., 1967, Natural Gas, a Study: Scientific Press, London, pp. 32-36.

Tissot, B. P. and Welte, D. H., 1978, Petroleum Formation and Occurrence, a New Approach to Oil and Gas Exploration, Published by Springer-Verlag, Berlin, 538 p.

Tongish, C. A., 1980, Helium - Its Relationship to Geologic Systems and Its Occurrence with the Natural Gases, Nitrogen, Carbon Dioxide, and Argon: U.S. Department of the Interior, Bureau of Mines, Report of Investigations 8444,176 p.

Weiss, R. F., 1971, Solubility of Helium and Neon in Water and Seawater: Journal of Chemical and Engineering Data, v. 16, no. 2, pp. 235-241.

Wescott, E. and Turner, D. (Editors), 1981, Geological and Geophysical Study of the Chena Hot Springs Geothermal Area, Alaska: A geothermal resource investigation by the Geophysical Institute, University of Alaska for the U.S. Department of Energy, Division of Geothermal Energy, 65 p., plus plates.

Zarella, W. M., 1969, Applications of Geochemistry to Petroleum Exploration: in Unconventional Methods in Exploration for Petroleum and Natural Gas, Pub. by Southern Methodist Univ. Press, Dallas, Texas, pp. 29-41. 
Reprinted from

Geophysical Research Letters

Vol. 2, No. 6, June 1975

HEIIUM SURVEY, A POSSIBLE TECHNICUE FOR LOCATING CEOTHERMAL RESERVOIRS

Alan A. Roberts, Irving Friedman, Terrence J. Donovan, and Edward H. Denton

U.S. Geological Survey, Denver, Colorado 80225

Abstract. Measurements were made of the helium concentration in the soil gases surrounding the Indian Hot Springs, Idaho Springs, Colorado. The helium concentration was shown to vary in a regular manner from the background level of $5.2 \mathrm{ppm}$ to a high of more than $100 \mathrm{ppm}$ near a wam $\left(26^{\circ} \mathrm{C}\right)$ water seep, and more than $1,000 \mathrm{ppm}$ near a hot $\left(40^{\circ} \mathrm{C}\right)$ water seep. Such an association of helium in the soil gas with these hot waters near the earth's surface suggests the possible utility of helium surveys in locating hidden geothermal reservoirs.

It is becoming increasingly apparent that geothermal energy may one day be a significant contributor to our energy supply. (See for example Anderson and Axtell, 1972; Amstead, 1973; Hickel, 1972.) However, exploration capability is in the infant stage. To quote halter Hickel, (1972, p. 22) "At the present tine, the most reliable exploration technique for new geothermal reservoirs is to find areas containing hot springs, a situation similar to that in the petroleum industry in the early 1900 's when petroleum exploration consisted of finding areas of surface oil seeps."

Preliminary work by Margaret Hinkle and coworkers at the U.S. Geological Survey (oral communication, 1975) has shown a high concentration of helium ( $>100 \mathrm{ppm}$ ) in the gases dissolved in the water from seven widely scattered hot springs in the western United States. These investigators also found anomalously high helium levels in the soil gases near a hot spring in Yellowstone National Park.

We attempted therefore to apply a portable helium detector that we have been developing for oil and gas exploration to the problem of locating geothermal resource areas. We present here our work on the concentration of helium in the soil gases around the Indian Hot Springs Resort, Idaho Springs, Clear Creek County, Colcrado (Long. $105^{\circ} 30^{\prime}$; Lat. $39^{\circ} 45^{\prime}$ ).

\section{Sample Collection and Analysis}

Measurements of helium in soil gases were made with a comercial helium leak detector mounted in a small truck. This instrument consists of a small ( $1 \mathrm{~cm}$ radius) mass spectrometer set to collect helium (mass 4) ions. These ions are distinguishable from triplycharged carbon, the only ions at nominal mass 4 that we might expect to interfere. The electron accelerating voltage can be adjusted to ionize helium without producing triply-charged carbon ions. The power to the leak detector was supplied by a propane-fueled generator which was

Copyright 1975 by the American Geophysical Union. electronically stabilized in voltage, frequency and wave form. High source pressure and high filament temperature maximized sensitivity of the mass spectrometer to helium.

The sample probes (steel tubing) were driven into the soil to a depth of about $0.5 \mathrm{~m}$. Gas was slowly pumped out of the probe. A small amount of this gas was allowed to leak into the mass spectrometer source. Periodically the mass spectrometer was switched to a sample of helium in compressed air standardized chromatographically by the U.S. Bureau of Mines, Helium Division at $5.26 \pm 0.05 \mathrm{ppm}$ as well as to a sample containing $7.60 \pm 0.05 \mathrm{ppm}$ helium for calibration of sensitivity. With this comparison technique our instrumentation detects changes in helium abundance in the gas

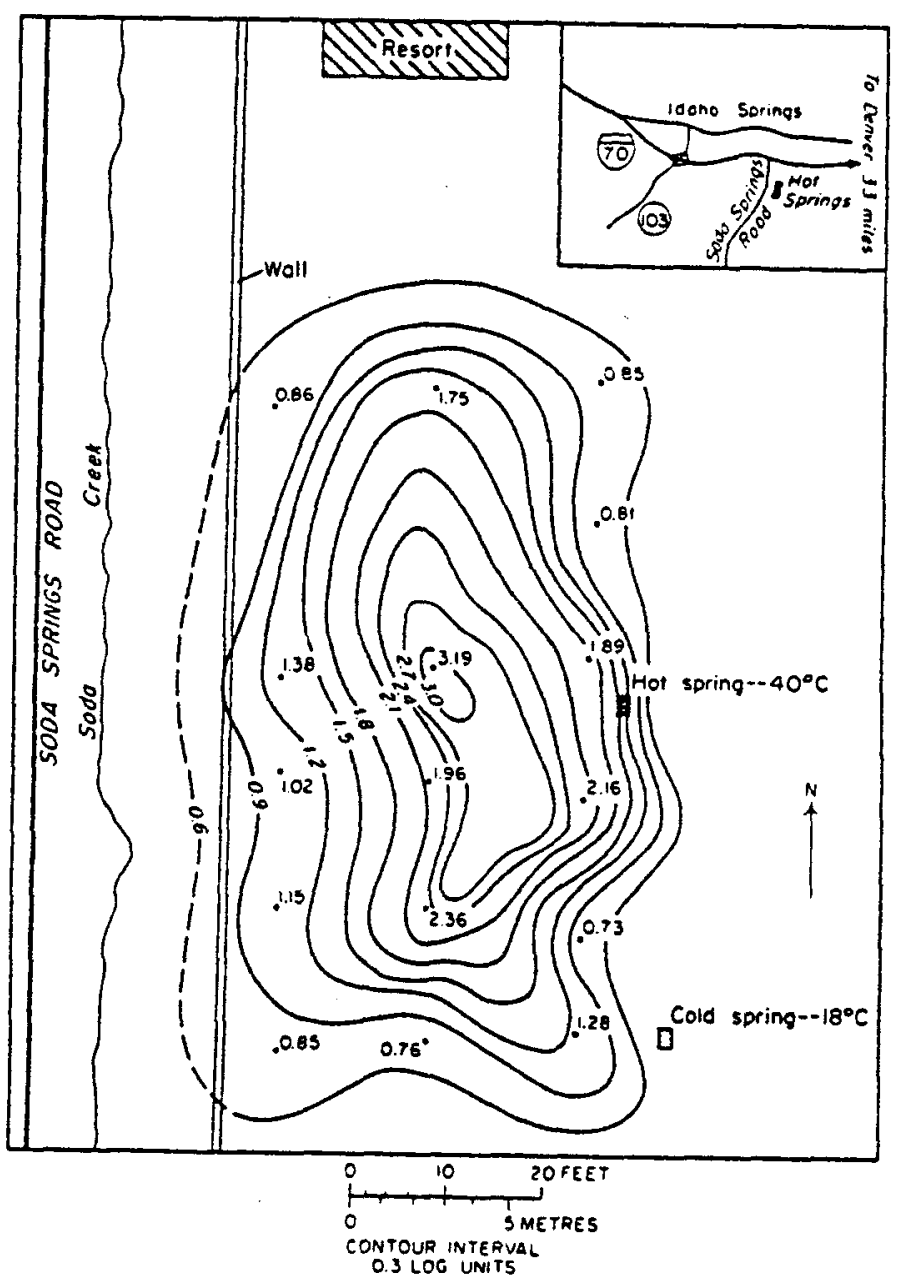

Figure 1. Map showing isopleths of the logarithm of the helium concentrations (ppm) in soil gases around a hot spring south of the Indian Hot Springs Resort, Idaho Springs, Colorado. 


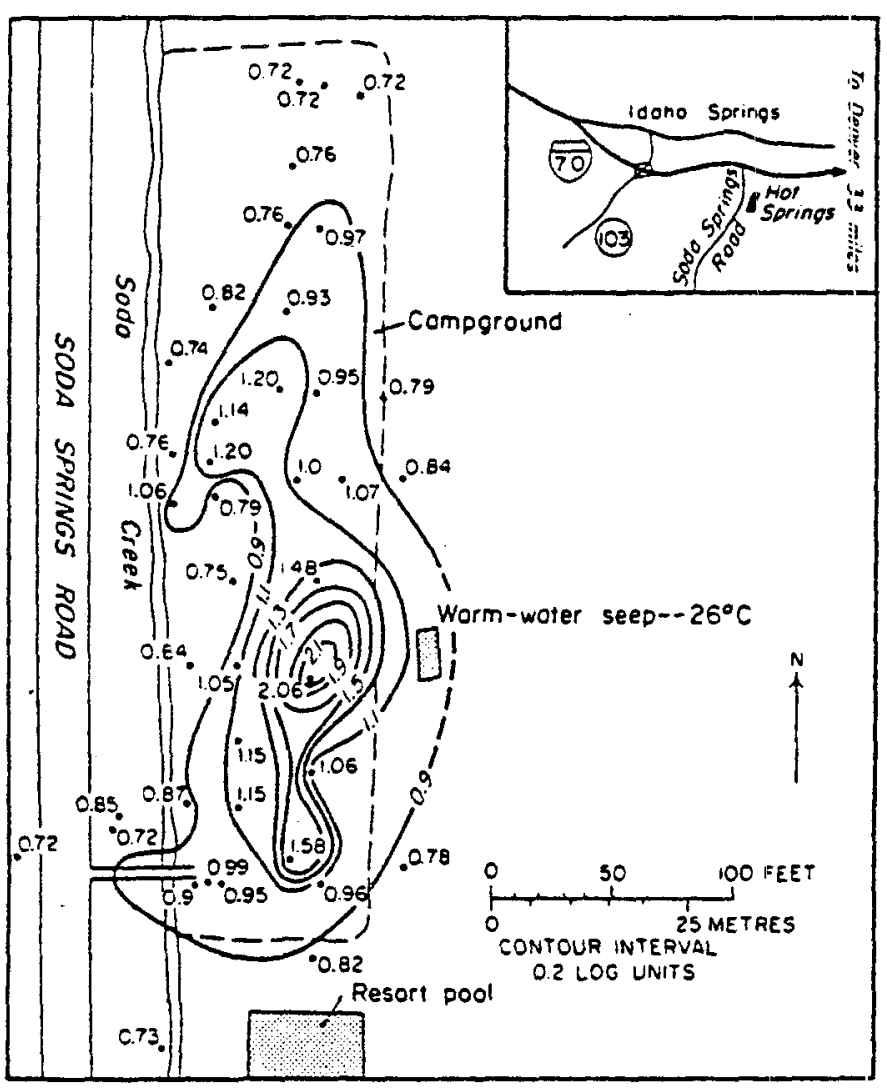

Figure 2. Map showing isopleths of the logarithm of the helium concentrations ( $p p m$ ) in soil gases around a hot spring north of the Indian Hot Springs Resort, Idaho Springs, Colorado.

stream of about $0.05 \mathrm{ppm}$ ( 50 parts per billion). A single measurement takes about 3 to 4 minutes, including the time to insert and extract the probe.

\section{Results}

The results of the helium survey involving 63 stations taken near the Indian Hot Springs Resort are shown in Figures 1 and 2. Figure 1 shows that the concentration of helium in the soil gases varies in a regular manner from a low of $5.4 \mathrm{ppm}(0.73 \mathrm{log}$ units) in front of the cold $\left(13^{\circ} \mathrm{C}\right)$ water seep to a high of more than 1,000 ppm ( $3.19 \mathrm{log}$ units) in front of the hot $\left(40^{\circ} \mathrm{C}\right.$ ) water seep. In contrast, numerous readings taken in the surrounding $f \in w$ square kilometres of countryside showed only the $5.2 \mathrm{ppm}$ concentration of helium that is typical of the atmosphere.
Figure 2 illustrates a similar increase in helium concentration to a peak greater than $100 \mathrm{ppm}(2.1$ $10 g$ units) located near a warm $\left(26^{\circ} \mathrm{C}\right.$ ) water seep about 100 metres north of the hot seep. Subsequent replicate readings taken under different weather conditions showed that temperature, wind velocity, and barometric pressure have no observable efiect on the concentration of helium in soil gas at Indian Hot Springs Resort.

\section{Discussion}

The above results cemonstrated dramatically a definite association of helium in soll gases with near-surface hot waters. Preliminary work done in several other hot-spring areas by us and at Yellowstone National Park by Margaret Hinkle (oral communication, 1975) suggests that this association is a common occurrence.

The solubility of helium in water is unusual in that it does not continually decrease with increasing temperature. It decreases up to $30^{\circ} \mathrm{C}$ and increases above that (Mazor, 1972). We believe that hot water under pressure can act as an excellent scavenger of the helium being produced from the readioactive decay of uranium and thorium in rocks and soil. As this water nears the surface it will be both cooler and under less pressure, thereby allowing the helium to excape from solution and diffuse up through the soil to the surface where it can be measured.

Acknowledgments. The authors thank William $D$. Long and Mary Dalziel sor their friendly assistance in sample collection and analysis.

\section{References}

Anderson, David N. and L. H. Axtell, eds., Compendium of First Day Papers presented at the First Conference of the Geothermal Resources Council: El Centro, California, Geothermal Resources Council, pp. 1-77, 1972.

Armstead, C. H., ed., Geothermal Energy, Review of Research and Development: Paris, UNFSCO, Pp. 1-186, 1973.

Hickel, W. J., Geothermal Energy--A National Proposal for Geothermal Resources Research: University of Alaska, p. 22, 1972.

Mazor, E., Paleotemperatures and other Hydrological Parameters Deduced from Noble Gases Dissolved in Groundwaters, Jordan Rift Valley, Israel: Geochimica et Cosmochimica Acta, v.

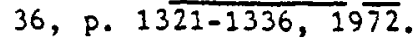

(Received March 24, 1975

Accepted April 9, 1975) 


\section{INTRODUCTION}

During the month of August 1984, a soil helium survey was conducted over geothermal prospects in the Copper River Area, Copper Center, Gulkana, Alaska.

This program was undertaken by the Ceophysical Institute, University of Alaska, with the objective of finding whether there are any helium anomalies in the area under consideration.

An exploration crew from the Geophysical. Institute collected 34 soil and 13 mud (water saturated soij) samples during this program.

The analyses of the samples and the interpretation of the resulting data were performed at the geochemical laboratories of Chemical Projects Limited, Toronto, Ontario. 


\section{SURVEY TECHNIQUES}

\subsection{Sampling Methods}

Thirty-four soil and thirteen mud (water saturated soil) samples were collected over the Copper Center Area. These samples were collected from random-spaced sampling stations, as indicated on Figure 1.

Both the soil and mud samples were preserved in hermetically sealed aluminum containers having a diameter of 1.5 inches and a length of 7 inches.

During the sampling procedure, the station barometric pressure, the air and soil temperatures and the sampling depth were measured and recorded at each sampling station.

\subsection{Analytical Procedures}

When the sealed containers with their contents were received at the laboratory, they were subjected to a period of equilibration at a constant temperature after which gas samples were extracted from each container and stored in Bistable gas samplers.

The gaseous contents of these Bistables were analyzed, employing a helium-hydrocarbon analyzer developed by Chemical Projects Limited, in order to determine the helium and hydrocarbon concentration in each sample. During the analysis, the concentration of helium in the sample was compared with that of standards which have helium concentrations of $5.20 \pm 0.03$ and $8.30 \pm 0.05$ ppm (by volume).

The practical detection limit for the helium analyses is $10 \mathrm{ppb}$ (by volume) while that for the hydrocarbons, if present at concentrations of less than 10,000 ppm, is approximately $1 \mathrm{ppm}$ (by volume). At higher concentrations exceeding $10,000 \mathrm{ppm}$, the detection limit is $500 \mathrm{ppm}$ (by volume). 
Since the helium concentration in the samples is a function of the soil and mud parameters, these were also determined for each sample. These data were used to correct the laboratory conditions back to 


\section{RIESULTS}

\subsection{Data Tables}

The corrected helium, methane, ethane, ethene and propene (= propene + propane) results for the soil samples and the mud samples are listed in Tables 1 and $1 A$. Also included in both tables are the statistical parameters and ordered listings of the helium values for the soil and mud samples.

In these tables and in the histogram, the following nomenclature is used:

Table 1 (Soil Samples)

Sample Number

$=$ The number that was assigned to each soil soil sample by the Geophysical Institute.

Depth

= The reported soil depth (in inches) from which the sample was collected.

Helium

$=$ The concentration of helium in the gas of the soil micropores, expressed in ppm He (by volume).

Hethane

= The concentration of each of these hydro-

Ethane

Ethene

Propane \& Propene carbon gases in the soil sample. Each concentration is expressed as $\mathrm{cm}^{3}$ gas at NTP/gm of soil and has been multiplied by a factor of $10^{8}$.

Table 1A (Mud Samples)

Sample Number

$=$ The number that was assigned to each mud sample by the Ceophysical Institute. 
CHEMICAL PROJECTS LTD.

TABLE 1
SOIL SAMPLES : (C84G-1SPA TO C84T-72SP)

PAGE : 1

(*)-CONCENTRATIONS OF HYDROCARBONS ARE IN (CC GAS AT NTP/GRAM OF SOIL) $x$ E-08

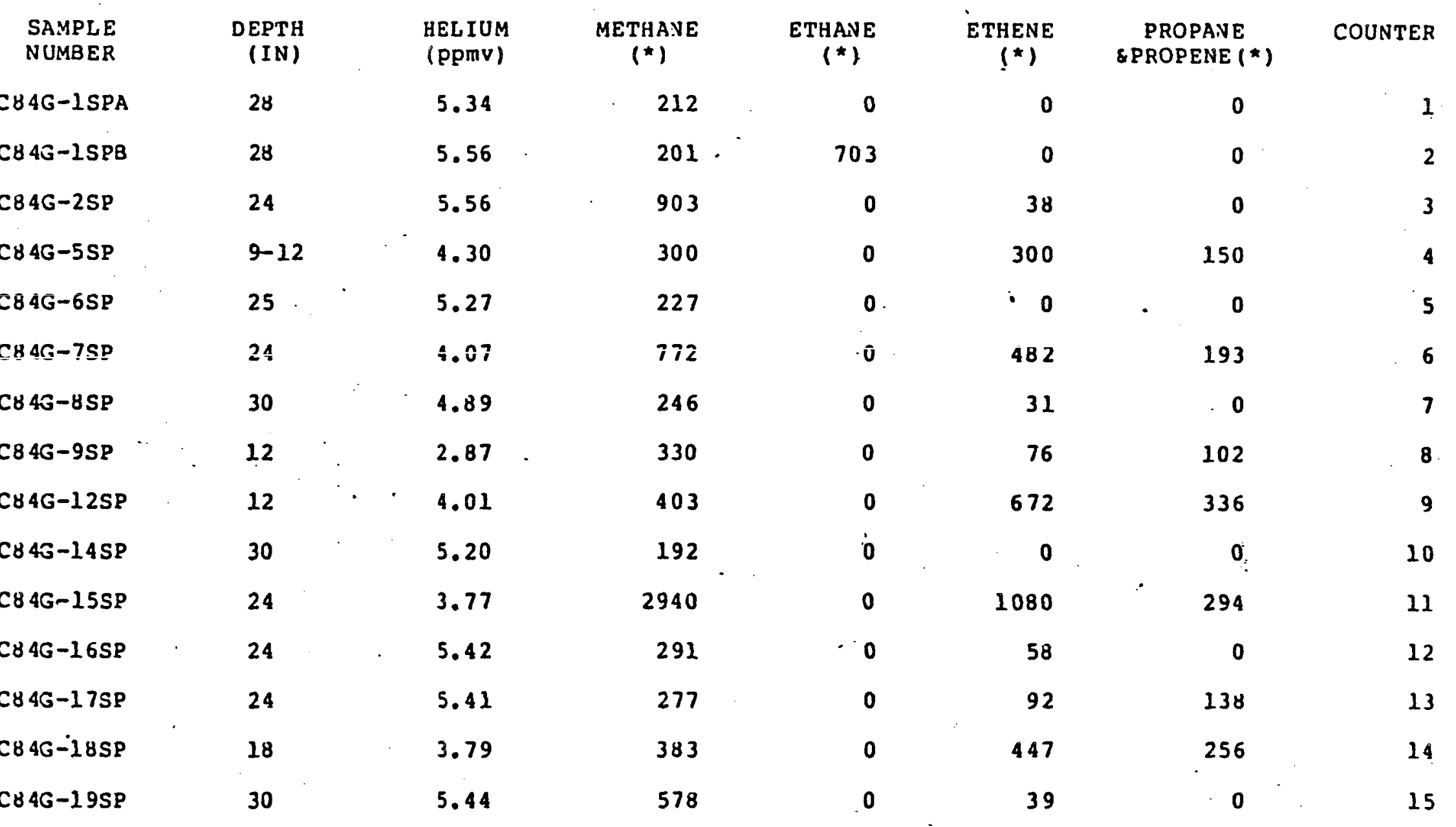


COMPANY : GEOPHYSICAL INSTITUTE PROJECT : COPPER I I

DATE :OCTOBER 1,1984

CHEMICAL PROJECTS LTD.

$$
\text { TABLE } 1
$$

PAGE : 2

SOIL SAMPLES : (C84G-1SPA TO C84T-72SP)

(*)-CONCENTRATIONS OF HYDROCARBONS ARE IN (CC GAS AT NTP/GRAM OF SOIL) $x$ E-08 SAMPLE
NUMBER

C8 4G-21SP

C8 $4 G-345 P$

C84G-37SP

C84G-38SP

CB $4 G-42 S P$

C8 4G-43SP

$\begin{array}{cc}\text { DEPTH } & \text { HELIUM } \\ \text { (IN) } & \text { (PPMV) } \\ 24 & 5.40 \\ 24 & 3.48 \\ 27 & 5.66 \\ 20 & 6.75 \\ 24 & 5.46 \\ 18 & 6.51 \\ 30 & 4.92 \\ 24 & 5.44 \\ 30 & 5.08 \\ 24 & 5.51 \\ 18 & 5.59 \\ 24 & 5.50 \\ 14 & 6.05 \\ 30 & 5.74 \\ 27 & 4.33\end{array}$

$\begin{array}{cr}\substack{\text { METHANE } \\(*)} & \begin{array}{c}\text { ETHANE } \\ (*)\end{array} \\ 192 & 0 \\ 512 & 0 \\ 118 & 0 \\ 162 & 0 \\ 208 & 0 \\ 130 & 0 \\ 266 & 0 \\ 223 & 0 \\ 218 & 14 \\ 171 & 0 \\ 156 & 7 \\ 281 & 0 \\ 312 & 0 \\ 246 & 10 \\ 810 & 0\end{array}$

ETHENE
$(*)$
85
39
27
62
65
89
89
56
79
30
18
24
20
101

PROPANE \&PROPENE (*)

COUNTER

*)

0

85

0

39

27

$6 \hat{2}$.

0

C84G-48SP

65

CB 4G-4 9SP

.44

C8 4G-56SP

08

C84G-57SP

.59

C8 4G-58SP

50

C8 4G-66SP

5.74

101

33

C8 4G-77SP

0

101

0


.

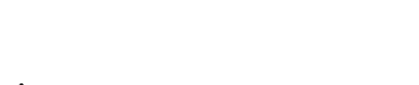

COMPANY : GEOPHYSICAL INSTITUTE PROJ ECT : COPPER II

DATE : OCTOBER 1,1984

CHEMICAL PROJECTS LTD. TABLE 1

PAGE : 3

$$
\text { SOIL SAMPLES : (C84G-1SPA TO C84T-72SP) }
$$

(*)-CONCENTRATIONS OF HYDROCARBONS ARE IN (CC GAS AT NTP/GRAM OF SOIL) $x$ E-OH

$$
\begin{aligned}
& \text { SAMPLE } \\
& \text { NUMBER }
\end{aligned}
$$

DEPTH

C8 4G-83SP

30

HELIUM

(ppmv)

METHANE
$(*)$
252
109
306
232
ETHANE
(*)

$4 . \leqslant 1$

5.36

7.31

6.83

232

o

ETHENE (*)

316

73

34

0
PROPANE SPROPENE (*)

COUNNTER

189

31

32

33

34 
COMPANY : GEOPHYS ICAL INST ITUTE PROJECT : COPPER II

DATE :OCTOBER 1,1984

PAGE :

HELIUM VALUES IN ASCENDING ORDER

\begin{tabular}{|c|c|c|c|}
\hline $\begin{array}{l}C 84 G-95 P \\
C 84 J-34 S P \\
C 84 G-15 S P \\
C 84 G-185 P \\
C 84 G-125 P \\
C B 49-7 S P \\
C 84 G-55 P \\
C 84 G-77 S P \\
C 84 G-83 S P\end{array}$ & $\begin{array}{l}2.87 \\
3.48 \\
3.77 \\
3.79 \\
4.01 \\
4.07 \\
4.30 \\
4.33 \\
4.61\end{array}$ & 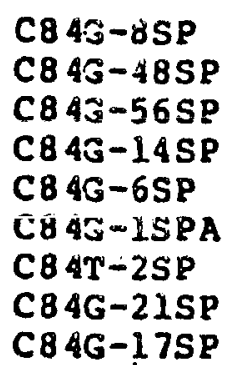 & $\begin{array}{l}4.89 \\
4.92 \\
5.08 \\
5.20 \\
5.27 \\
5.34 \\
5.36 \\
5.40 \\
5.41\end{array}$ \\
\hline
\end{tabular}

\begin{tabular}{ll|} 
CB 4G-16SP & 5.42 \\
CB 4G-49SP & 5.44 \\
CB 4G-19SP & 5.44 \\
CB 4G-42SP & 5.46 \\
CB 4G-61SP & 5.50 \\
CB 4G-57SP & 5.51 \\
C84G-1SPB & 5.56 \\
C84G-2SP & 5.56 \\
C84G-58SP & 5.59
\end{tabular}

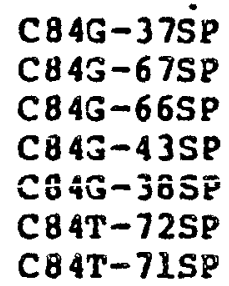

5.66

5.74

6.05

6.51

$6 . \overline{75}$

6.83

7.31 
COMPANY :GEOPHYSICAL INSTITUTE PROJECT :COPPER I I

TABLE 1

SOIL SAMPLES : (C $84 G-1 S P A$ TO C C4T-72SP).

\section{STATI ISTI $\underline{T}$ AL_P PARAMETERS}

HELIUM VALUES

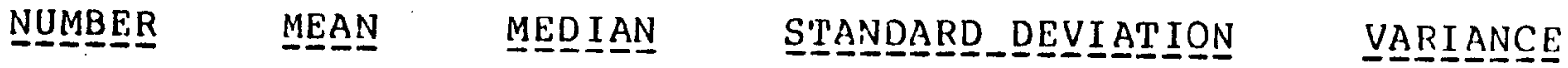

T'O'TAL

POPULATION

34

5.19

5.4 .1

0.96

0.93

B ACKGROUND

POPULATION

124.18

4.19

0.65

0.42

ANOMALI

\begin{tabular}{rrrrr}
$>4$ & \multicolumn{2}{c}{$>$} & \multicolumn{2}{r}{6.78} \\
$>3-4$ S.D. & 6.14 & - & 6.78 \\
$>$ & $2-3$ S.D. & 5.49 & - & 6.13 \\
$>$ I- & S.D. & 4.84 & - & 5.48
\end{tabular}


TABLE 1

HISTOGRAM OF HELIUM RESULTS FOR GEOPHYSICAL INSTITUTE BAR WIDTH $=0.25$ TOTAL NUMBER OF SAMPLES $=34($ C8MG-1SPA TO C84T-72.SP)

ษ

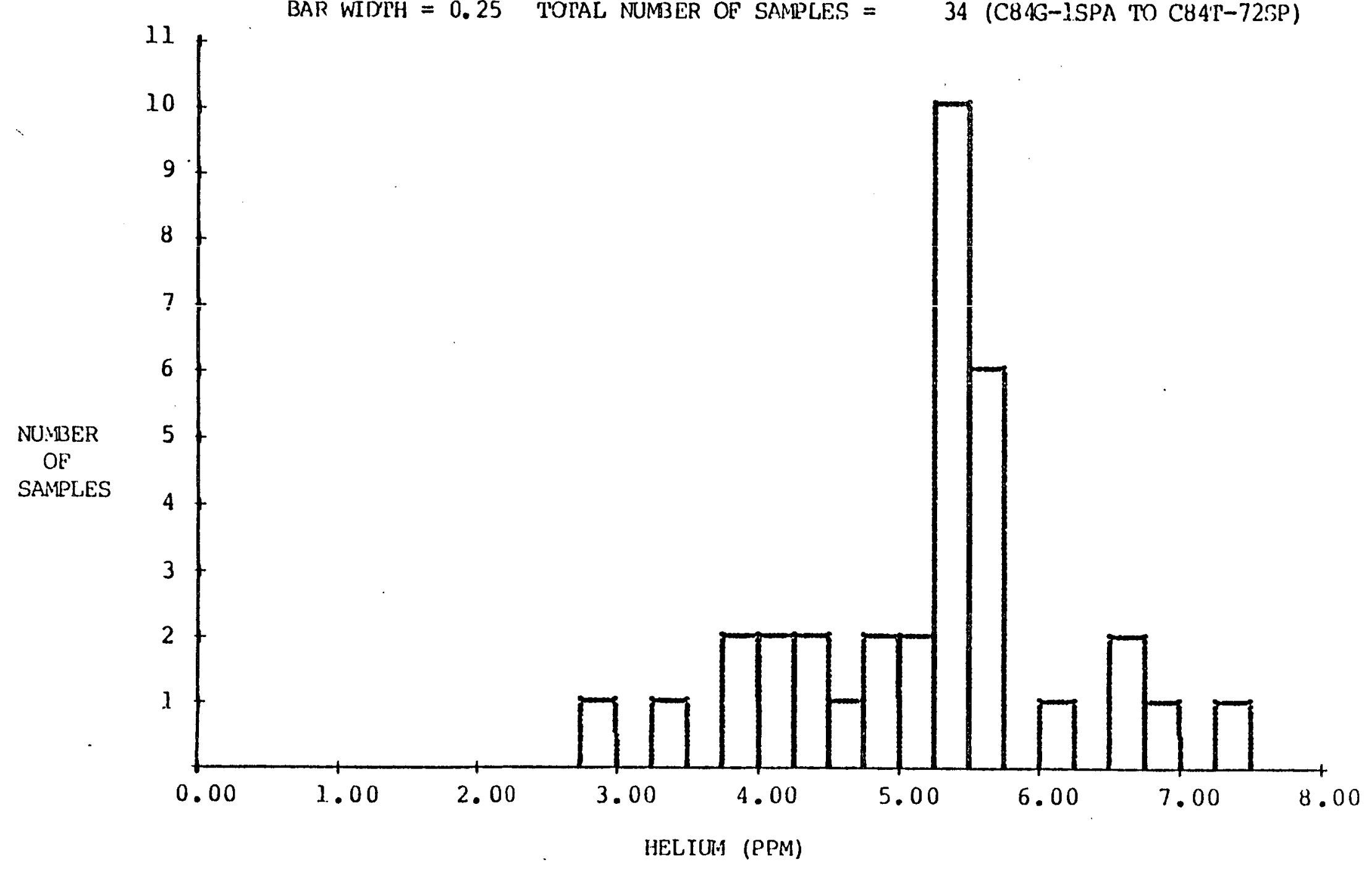


COMPANY :GEOPHYSICAL INSTITUTE PROJECT : COPPER II

DATE : OCTOBER 1,1984

CHEMICAL PROJECTS LTD.

$$
\text { TABLE } 1 A
$$

MUD SAMPLES : $(C 84 G-39 S P$ TO CY4G-62SP)

(*)-CONCENTRAtions of ALL GASES ARE IN (CC GAS AT NTP/CC OF MUD) $x$ E-08

PAGE : 1

$\begin{array}{cc}\text { SAMPLE } & \text { DEPTH } \\ \text { NUMBER } & \text { (IN) } \\ \text { C84G-39SP } & 12 \\ C 84 G-40 S P & 21 \\ C 84 G-41 S P & 20 \\ C 84 G-44 S P & 20 \\ C 84 G-45 S P & 18 \\ \text { C84G-46SP } & 30 \\ C 84 G-51 S P & 18 \\ C 84 G-52 S P & 20 \\ C 84 G-53 S P & 12 \\ C 84 G-54 S P & 18 \\ C 84 G-55 S P & 15 \\ C 84 G-59 S P & 21 \\ C 84 G-62 S P & 18\end{array}$

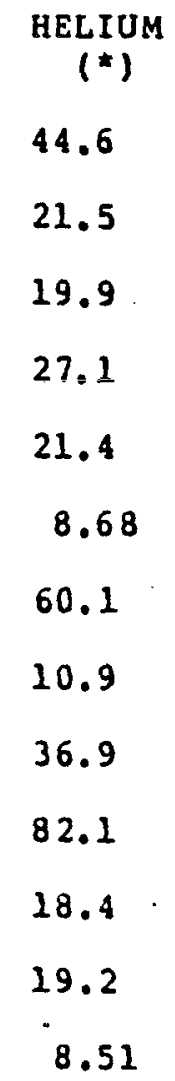

METHANE
$(*)$
2450
1060
504
754
114000
856
2610
15000
17000
9900
343000
358
1580

ETHANE
$(*)$
2250
0
0
62
0
24
96
1030
0
0
0
45
15

ETHENE
$(*)$
2860
931
336
1050
4860
42
3230
2890
673
2580
2880
203
84

PROPENE $(*)$

1080

1

31

268

2

203

3

050

419

บ논

5

42

63

6

635

7

8

9

10

11

12

84 
COMPAVY : GEOPHYSICAL INSTITUTE PROJECP : COPPER II

DATE : OCTOBER 1,1984

TABLE 1A

PAGE : 1

HELIUM VALUES IN ASCENDING ORDER

\begin{tabular}{lllll|lll|l}
$C 84 G-62 S P$ & 8.51 & $C 84 G-59 S P$ & 19.2 & $C 84 G-44 S P$ & 27.1 & $C 84 G-54 S P$ & 82.1 & 1 \\
$C 84 G-46 S P$ & 8.68 & $C 84 G-41 S P$ & 19.9 & $C 84 G-53 S P$ & 36.9 & \\
$C 84 G-52 S P$ & 10.9 & $C 84 G-45 S P$ & 21.4 & $C 84 G-395 P$ & 44.6 & \\
C84G-55SP & 18.4 & $C 84 G-40 S P$ & 21.5 & $C 84 G-51 S P$ & 60.1 &
\end{tabular}




$\begin{array}{lrrccr} & \text { NUMBER } & \text { MEAN } & \text { MEDIAN } & \text { STANDARD_DEVIATION } & \text { VARIANCE } \\ \begin{array}{l}\text { TOTAL } \\ \text { POPULATION }\end{array} & 13 & 29.20 & 21.40 & 21.70 & 472.00 \\ \begin{array}{l}\text { BACKGROUND } \\ \text { POPULATION }\end{array} & 9 & 17.30 & 19.20 & 6.47 & 41.80\end{array}$

\section{ANOMALY RANGE}

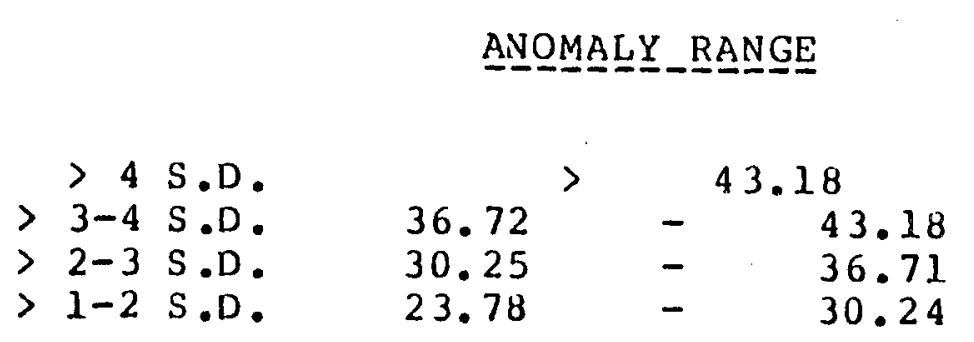

COMPANY : GEOPHYSICAL INSTITUTE,

PROJECT :COPPER I I

TABLE 1A,

DATE :OCTOBER $1,1.984$

MUD SAMPLES : (C84G-39SP TO C84G-62SP).

STATISTIICAL PARAMETER

HELIUM VALUES

S

$9.30-19.20$

$4 . .80$ 
HISPOGRAY OE HELIU

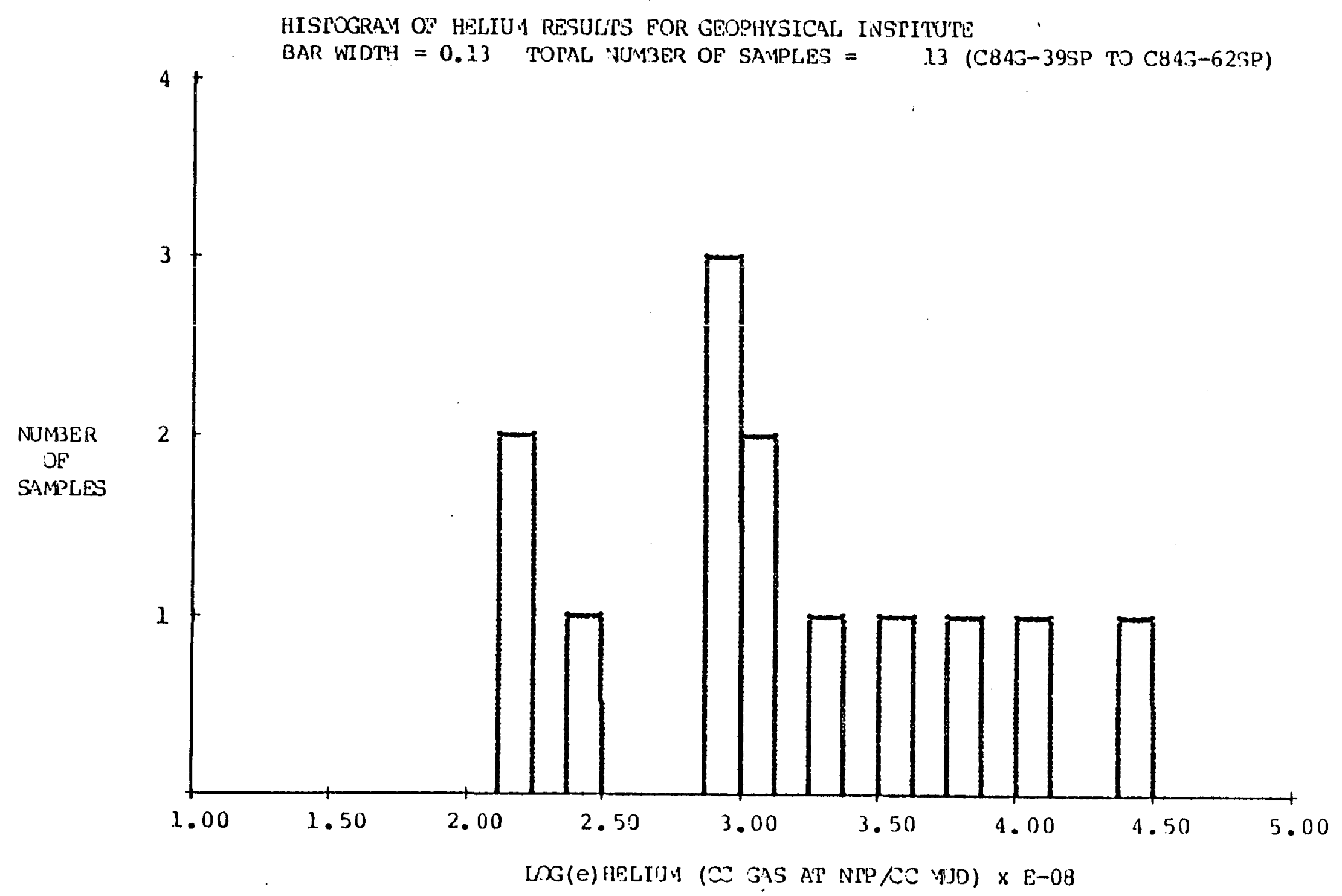


Depth

Helium

Methane

Ethane

Ethene

Propane \&

Propene
$=$ The reported depth (in inches) from which the sample was collected.

$=$ The concentration of helium in the mud or sediment samples which was dissolved in the iriterstitial soil water and bubble phase of the sample. Each concentration is expressed as $\mathrm{cm}^{3}$ He at NTP $/ \mathrm{cm}^{3}$ mud and has been multiplied by a factor of $10^{8}$.

Helium Log (e)

$=$ The natural $\left(\log _{e}\right)$ of the concentration of helium present in the mud samples.

$=$ The concentration of each of these gases present in the mud sample. Each concentration is expressed as $\mathrm{cm}^{3}$ gas at NTP $/ \mathrm{cm}^{3}$ mud and has been multiplied by a factor of $10^{8}$.

\subsection{Statistical Evaluation of the Data}

The soil samples and the mud samples were examined statistically. The two sets of data were treated in the same manner. The determination of the background for the data set was commenced by first sorting and listing the results $\left(X_{i}\right)$ in ascending order. The mean $\left(\bar{X}_{T}\right)$ was then calculated for the entire set of values. The subset of data having values equal to or less than $\bar{X}_{T}$ was then defined. The mean $\left(\bar{X}_{b}\right)$ and standard deviation $\left(S_{b}\right)$ for this subset were calculated and estimated to be the background mean and standard deviation. Anomalous values were assumed to be those results that exceeded the background mean by more than one standard deviation of the background population, that is, data greater than $\bar{x}_{b}+s_{b}$ were taken as being anomalous. In terms of $z_{i}=\left(x_{i}-\bar{x}_{b}\right) / s_{b}$, anomalous values correspond to those for which $z_{i}>1$. 
The anomalous values in each data set were ordered as indicated below into four categories according to the number of background standard deviation $\left(S_{b}\right)$ by which they exceeded the background mean. Increasingly anomalous categories are shown by colour coding in the following manner:

Range of Values.

(In values of $Z_{i}$ or the number. of standard deviation $\left(S_{b}\right)$ that the data exceed the background mean $\left(\bar{X}_{b}\right)$

$\begin{array}{rlr}>4 \text { S.D. } & \text { Red } \\ >3-4 \text { S.D. } & \text { Orange } \\ >2-3 \text { S.D. } & \text { Yellow } \\ >1-2 \text { S.D. } & \text { Green }\end{array}$

Colour Code

\subsection{Maps}

The sampling locations and helium results for the 34 soil samples and for the 13 mud samples collected in this survey are plotted in Figure 1. The map is drawn on a scale of 1:63360 and was prepared from a USGS topo map supplied by the Geophysical Institute.

On this map, the soil sampling locations are designated as hollow circles while the mud sampling locations are designated as squares. The soil and mud samples are coloured to accentuate anomalous helium values, as described in Section 3.2.

Each helium concentration is marked in a larger type at the site of the appropriate sampling location while the number assigned to each sampling station is given in a smaller type.

Note: Figure 1 Map has been replaced by Plate 3 (in pocket). 


\section{COMMENTS AND RECOMENDATIONS}

This soil helium survey consists of 44 samples collected from 4 prospect areas (Area A - 16 samples; Area B - 2. samples; Area C - 13 samples and Area $D$ - 12 samples), and of 3 individual samples (C84G67SP, C84G77SP and (84G83SP) unrelated to each other.

The soil sample population can be divided into two groups - soil samples (samples in which the micropores contain a gas phase) and mud samples (soil samples in which the micropores are completely filled with water). The two types of samples have been treated statistically as two separate groups. Each of these two groups has its characteristic range of helium and hydrocarbon values. The individual helium and hydrocarbon values are comparable within each specific group but not outside of a given group. In order to compare helium levels in soil and mud, the data obtained are presented in Figure 1 in terms of standard deviations above the background mean.

The results indicate presence of anomalous helium and hydrocarbon values within each of the four prospect areas. These may be related to the presence of deep faults and fissures, higher than normal concentrations of. uranium or to the presence of geothermal energy sources. The interpretation will depend on the geology of the area under consideration.

In view of the limited number of samples, we have based our soil and mud statistics on the combined population of all the samples rather than on the samples collected within each of the separate prospect areas. The validity of the approach depends on the geological characteristics of the area. It may be worthwhile to examine individual prospects as separate entities, provided the number of samples that have been collected is adequate to properly establish the true background mean of each of the prospect areas. 
CHAPTER 3

CORRECTION AND ANALYSIS OF 1984 COPPER RIVER BASIN HELIUM SOIL GAS SURVEY DATA

by

Kim R. Green

\section{Introduction}

Three types of samples can be collected in helium surveys - soil gas, soil and water. Soil-gas samples involve the collection of sub-surface soil pore space gas and provide a direct measurement of pore space helium content. Unfortunately, this type of sample cannot be collected in wet, frozen, or rocky soils. When soil and water samples are taken, a volume of atmospheric air is also collected along with the sample. After a period of equilibration, analyses of these samples are accomplished by removing a gas sample from the air space (headspace) at the top of the contained sample. The frequently wet soils and permafrost present in the Copper River Basin required the collection of soil samples in this survey.

\section{Sampling Procedures}

Ninety-two soil samples were collected in 1984 for helium analysis. Sampling was designed to augment the results of the 1982 survey. Using a hand auger, a hole of about $3 / 4$ meter deep was drilled into surface sedinents. The soll core from the bottom of the hole was placed on a plastic tray where any chunks were broken up and pebbles were removed. The soil was put into \#301 metal food cans and gently tamped into place while filling. The can lip was carefully cleaned, a lid was fitted onto the can and sealed with a handoperated can sealer. Cans were filled to approximately one inch from the top of the can, except for permafrost samples where cans were filled to the top to allow for melting. The suitability of these metal cans as helium containers 
has been carefully evaluated in a recent study reported in Appendix A.

Soil temperature at the depth of sampling and air temperature were recorded at each site. Thermometers used in the survey were calibrated in a water-ice bath. Atmospheric pressure was also measured at each site with Thommens field altimeters. These altimeters were calibrated against the anaeroid barometer at the U.S. National Weather Service, Fairbanks office. Soil type, moisture content and any other comments of interest (weather, etc.) were recorded at each site.

Forty-seven duplicate soil sample splits were collected in the survey area for analysis by Chemical Project Ltd., Ontario, Canada. Special aluminum containers were provided by Chemical Projects for sample collection. At each of these 47 sites, the soil was carefully mixed on a plastic tray and split into two samples which were sealed into the two different types of containers (非301 food cans and special Chemical Projects containers) within one minute of one another. In this way we hoped to be able to compare a large suite of replicate samples analyzed by two different laboratories. Analytical Me thods

Samples collected in metal food bans were shipped to Denver for analysis by the U.S. Geological Survey, Branch of Isotope Geology. Samples were placed in a $33^{\circ} \mathrm{C}$ oven for a period of 18 days to allow equilibration between helium in the soil and helium in the container headspace. This temperature was chosen because it is very close to the temperature of helium's minimum solubility in water. At the time of analysis, a sample is removed from the oven and placed on a can-piercing apparatus. This device is attached through a series of valves and fittings to a quartz pressure transducer. The pressure transducer is connected to a pressure computer that records the pressure inside the sample container upon piercing. Headspace gas is then removed from 
the can by insertion of a syringe through a septum fitted onto the can piercer. The over-pressured gas inside the can fills the syringe. This gas is then reinjected into the can and the syringe is allowed to fill again. This procedure is repeated two more times. This "pumping" allows equilibration to occur between any atmospheric air present in the valves and fittings of the can piercer and the headspace gas. Three successive gas samples are removed for analysis. I:E samples are found to be underpressured (container pressure lower than lab pressure) a syringe fitted with a three-way valve was used to remove headspace gas samples.

The canned sample and pressure transducer are then attached via the piercing apparatus to a vacuum pump. Atmospheric or lab pressure is recorded and the sample is evacuated for approximately two minutes or until the vapor pressure of water is reached as indicated by the pressure gauge. This evacuated pressure is noted and, upor closing of valves on the fittings, is used to determine whether the system is holding a vacuum. Fifty cc syringes are then used to inject air into the evacuated system until the atmospheric or laboratory pressure is reached. The amount of air injected is recorded and represents the combined volumes of gaseous pore space and headspace, or headspace, within a sample. The collected headspace samples are analyzed for helium-4 using a modified helium leak detector mass spectrometer. Precision of this measurement is $\pm 10 \mathrm{ppb}$.

The volume of the valves and fitting on the can piercing apparatus was determined to be $4.67 \mathrm{cc}$. This value was later subtracted from the recorded headspace volumes since it is not part of the actual gas volume within the sample container. If desired, the determined "fittings volume" can also be used to determine and correct for the amount of dilution that atmospheric air present in this equipment would create in the helium in headspace gas. The 
technique of evacuation used in the deadspace measurements also serves to remove any residual helium that may be present in the fittings of the piercing apparatus.

After analysis, the sample is removed from the can piercer, weighed, opened, and soil type and water content described. Heights from the can lip to the soil surface are measured to allow the geometric determination (非 301 can radius $=3.68 \mathrm{~cm}$ ) of headspace volume. Gaseous pore space volume is later determined by the subtraction of the calculated headspace volume from the measured deadspace volume. Opened cans are placed in an oven at approximately $80^{\circ} \mathrm{C}$ and periodically weighed until a constant weight is obtained (about one week) to determine the amount of soil moisture.

The fourty-seven duplicate soil samples were shipped to Chemical Projects, Itd., Toronto, where they were subjected to a period of equilibration at a constant temperature. Gas samples were then extracted from each container and analyzed using a helium-hydrocarbon analyzer to determine both helium and hydrocarbon concentration in each sample. Details of the analysis procedures and the correction factors applied to calculate helium. concentration in the original soil samples are proprietary to Chemical Projects Ltd. (see Chapter 2, Appendix B).

\section{Data Treatment}

The measured concentration of helium in soil sample container headspace gas is not necessarily an accurate measure of the helium concentration that existed in the original soil pore space. Corrections must be applied to a raw headspace helium value in order to calculate the concentration of helium that existed in the soil sample at the time of collection. This concentration of helium is determined in different ways depending on which part of the sample is considered to contain most of the helium. The soil samples can be divided 
into two groups - soil samples which contain gaseous pore space and watersaturated (mud) samples. If there is more measurable gaseous pore space in the soil sample than soil moisture, the helium concentration can be determined as a volume of helium per volume of gaseous pore space. If a sample contains more soil moisture, or is totally composed of water, the helium concentration can be calculated as a volume of helium per volume of soil moisture or water. Equations have been derived (Green, 1984) for calculating the concentration of helium in the gasous pore space of a soil sample and in the soil moisture of a water-saturated soil using various measured parameters. These parameters include air temperature, soil temperature, and barometric pressure measured at each field location; and deadspace volume, headspace helium concentration, headspace volume, pore space volume, container pressure and water content measured in the laboratory.

The distinction between samples that are water-saturated and samples with measurable gaseous pore space was made by subtracting the calculated headspace volume from the measured deadspace volume. Samples found to have non-existent gaseous pore space were treated as water-saturated. Calculated negative pore space values for a few of the samples indicate that there is some error in the technique used to measure the deadspace and headspace volumes. The effect of this error on helium concentrations is examined in the Error Analysis section of this chapter (Appendix D). As a result of this problem, samples found to have very small gaseous pore space volumes were examined individually to determine whether their helium concentration should be calculated as helium in gaseous pore space or as helium in solil moisture. Considering the technique used to measure pore space, it was corlcluded that samples with pore space volumes greater than $10 \mathrm{cc}$ were best treated as non-wet soils while samples with gaseous pore space volumes of less than $10 \mathrm{cc}$ were treated as water- 
saturated, regardless of field classification. The actual concentration of helium in a soil sample, whether calculated as helium in gaseous pore space or helium in soil moisture would yield equivalent results since each quantity is dependent on the other. Of the 92 samples analyzed by the U.S.G.S., 17 were found to be water-saturated.

While measurement of the pressure inside the sample containers at the time of analysis $\left(P_{c}\right)$ was made, these values were not used in the treatment of the data for reasons discussed in the error analysis section (Appendix D). Container pressures were calculated based on thermodynamic differences between the field and laboratory conditions:

$$
\frac{\mathrm{T}_{1} \mathrm{P}_{f}}{\mathrm{~T}_{\mathrm{f}}}=\mathrm{P}_{\mathrm{c}}
$$

where

$$
\begin{aligned}
\mathrm{P}_{\mathrm{c}}= & \text { Pressure inside sample container at time of analysis } \\
\mathrm{T}_{1}= & \text { Temperature of sample (labcratory) at time of analys is } \\
\mathrm{P}_{\mathrm{f}}= & \text { Pressure of surficial sample at time of collection. Taken to } \\
& \text { be atmospheric pressure } \\
\mathrm{T}_{\mathrm{f}}= & \text { Temperature of gases inside contained soil sample at time of } \\
& \text { sealing. Taken here to be temperature of soil at time of } \\
& \text { collection. }
\end{aligned}
$$

This is a valid estimation of pressure inside the container if there is no gas produced or consumed within the container or lost due to leakage.

The concentration of helium in air was assumed to be constant and equal to $5.240 \mathrm{ppm}$ (Glueckhauf, 1946; Reimer, 1976).

Fourteen of the 47 samples analyzed by Chemical Projects, Ltd, were determined by them to be water-saturated soils or muds. Soil and mud parameters were determined for each sample and, in conjunction with field measurements, were used to correct the laboratory conditions back to the field conditions at 
the time of sample collection. These methods of data treatment are proprietary (see Chapter 2, Appendix B).

Results

Samples were taken at 87 sites. Sites were chosen based on the results of the 1982 Copper River Basin survey. Three major areas were sampled: (1) an area near the Richards on Highway at the junction of the Tazlina and Copper Rivers; (2) an area west of upper Klawasi mud volcano extending to the lower Klawasi mud volcano; and (3) an area about 4 miles SW of Shrub mud volcano and north of both upper and Iower Klawas:

Helium concentrations in samples found to be water-saturated (U.S.G.S. analyzed) were calculated as cc's of helium per cc of soil moisture. The remaining samples were evaluated for their helium content as cc's of helium per cc of gaseous pore space. Results are presented in Plate 2, which shows sample location, sample number and calculated concentrations of helium in gaseous soil pore space. Calculated concentrations of helium in soil moisture are enclosed in parentheses.

Appendix B contains tabulated data for the soil samples, including dates and times of collection, air and soll temperatures, field descriptions of soil type and moisture content, field barometric pressures, weights of soil moisture, and measured concentrations of helium in container headspace. Appendix $C$ contains tabulated results of the corrected data, including calculated container pressures, volumes of gaseous pore space, uncorrected helium in headspace values, and corrected helium in pore space or helium in soil moisture values.

Calculated concentrations of helium in pore space for all the U.S.G.S.analyzed samples range from $3067 \mathrm{ppb}$ to $6661 \mathrm{ppb}$. The mean and standard deviation of the samples is $566 \pm 467 \mathrm{ppb}$. A histogram of these 
concentrations is given in Figure 3-1. To allow a better visualization of the spread of data an expanded histogram is presented in Figure 3-2. The corrected helium results for the 34 soil samples and 13 mud samples analyzed by Chemical Projects Ltd. range from 2870 to $7310 \mathrm{ppb}$ and are listed in Chapter 2, Appendix B. Discussion

Results from soil samples collected during the 1984 survey cannot be directly compared to the numerical results from soil samples taken during the 1982 survey because the 1982 headspace He values cannot be corrected to helium concentrations in pore space or soil noisture.

The duplicate set of 1984 samples analyzed by Chemical Projects, Ltd., were collected at the same sampling siltes as the U.S.G.S. analyzed samples, but at fewer locations. This duplicale set of samples allowed comparisons between the techniques developed by Chemical Projects, Ltd., and the techniques and corrections developed at the U.S.G.S. and used here. These comparisons are discussed in Chapter 2.

The two types of soil samples collected in the survey, i.e., samples in which there is gaseous pore space and samples where soll pore space is completely filled with water, must be treated as completely separate data sets.

In the error analysis section (Appendix D), it is estimated that a typical pore space He concentration for the U.S.G.S. analyzed samples has an associated error of $\pm 135 \mathrm{ppb}$. This amount of error is not large compared to the range of values (3067-6661 ppb) for the data set and suggests that interpretation of results can be done with a reasonable level of confidence. The pore space He concentrations over the entire study area have been broken down into 4 levels on Plate 2. Higher concentrations of helium in the 
$\begin{array}{cccc}\text { SYMBOL } & \text { COUNT } & \text { MEAN } & \text { ST. DEV. } \\ X & 75 & 5565.947 & 466.651\end{array}$

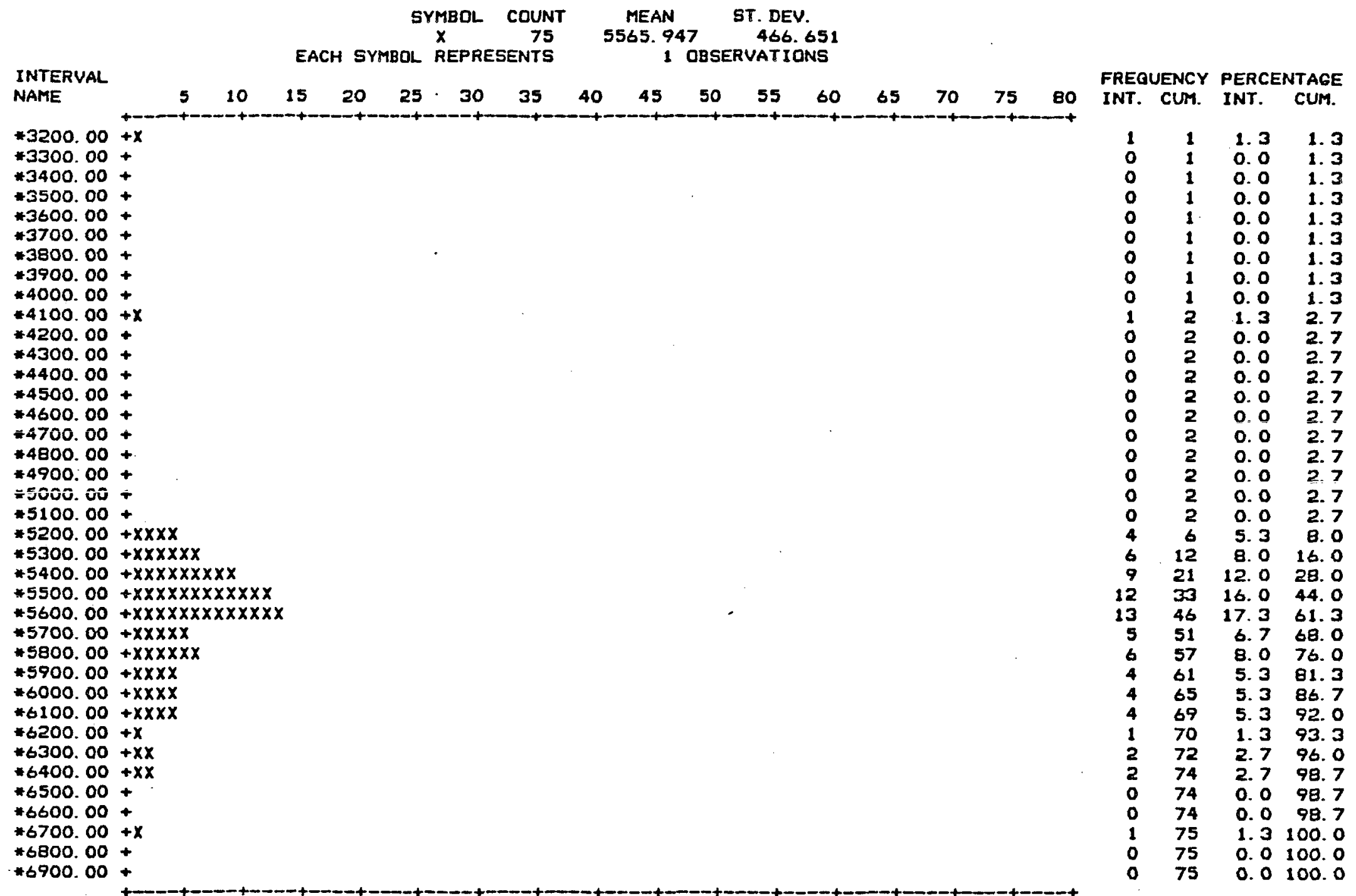

Figure 3-1. Histogram of helium concentrations in gaseous soil porespace for the samples analyzed by the U.S.G.S. helium concentration in parts per billion ( $p p b)$. 


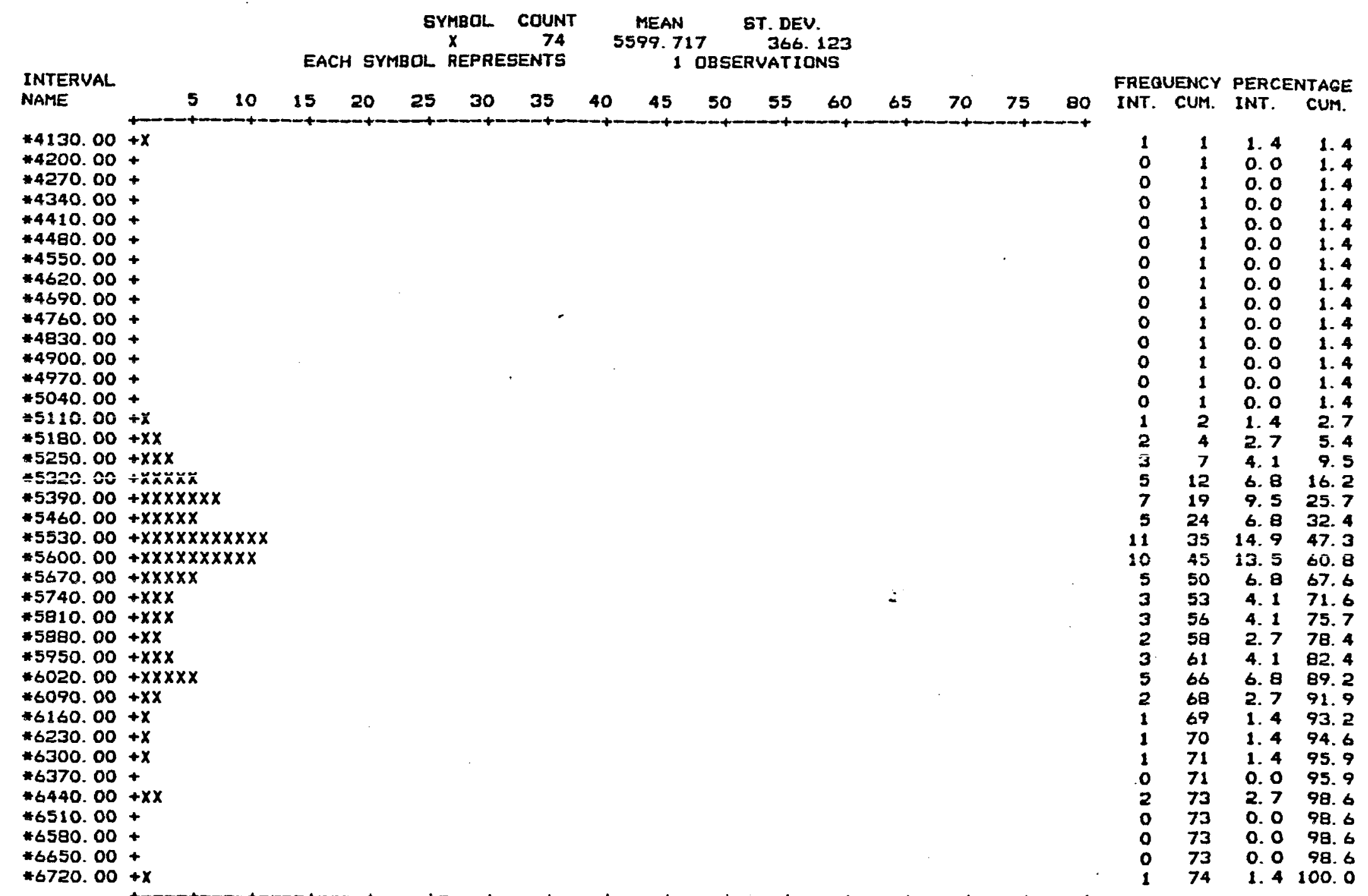

Figure 3-2. Expanded-scale histogram of Figure 3-1. Helium concentration in parts per billion ( $p p b$ ). 
water-saturated soils are also identified on Plate 2 . It can be noted from Appendix C that negative He concentrations were determined for samples G46, G62 and G74. Since these values are obviously incorrect, caution must be used In the interpretation of calculated helium in soil moisture concentrations. This problem is due to the nature of the calculation and the insolubility of helium in water at typical soil temperatures. Since these concentration values are very small $\left(10^{-8} \mathrm{cc} \mathrm{He} / \mathrm{cc} \mathrm{H}_{2} \mathrm{O}\right)$, small errors in parameters used in the correction equation, such as $P_{c}$ can produce negative values.

Although the determined helium in soil moisture values cannot be taken as absolute, it is still possible to determine a relative ranking of concentration values. Samples with values somewhat above the mean helium in soil moisture concentration of $1.58 \times 10^{-7} \mathrm{cc}$ He/cc $\mathrm{H}_{2} \mathrm{O}$ are clearly anomalous .

Values for helium in pore space less than the threshold of $6000 \mathrm{ppb}$ used in Plate 2 may also be anomalous ly high depending on what the background level of helium in this area is considered to be. The mean of the data set (5566 $\mathrm{ppb}$ in this case) is often considered to be the background value for an area. However, if helium values are high throughout an area, this can mask the true background value. A second background value can be statistically established by identifying those samples with helium values equal to or less than the mean. A mean and standard deviation of these samples is then determined and these values used to subsequently establish anomaly levels. This was done with the pore space helfum data (background mean $=5306 \mathrm{ppb}$ 4434), but did not reveal any new trends or changes in the anomaly pattern shown on Plate 2. 


\section{References}

Glueckhauf, E., 1946. A micro-analysis of the helium and neon contents of air. Proceedings of the Royal Scciety of London, V. 185, p. 98-119.

Green, K. R., 1984. An algorithrn for determining soil and water helium concentrations from headspace analyses: Examples of geochemical applications in Long Valley, California, and the Fiji Islands, Colorado School of Mines M.S. Thesis, 197 p., 3 App.

Reimer, G. M., 1976. Helium detection as a guide for uranium exploration: U.S. Geological Survey Open-Tile Report 76-240, 15 p.

Roberts, A. A., 1984. Personal communication.

Wescott, E. M. and Turner, D. L., 1983. Final report on the investigation of the geothermal energy resource potential of the eastern Copper River Basin, Alaska. Alaska Division of Geological and Geophysical Surveys, report No. RSA $82-5 X-670,123 \mathrm{p}$. 


\section{APF'ENDIX A}

Evaluation of metal food cans as sample containers for helium in soil surveys

Helium can rapidly diffuse through many materials due to its small size and chemical inertness. Containers used to collect soil samples should have a low leakage rate for helium over the period of time that the samples remain in the container prior to analysis. Metal cans manufactured for home food canning are lightweight, inexpensive, and readily available. A study was therefore undertaken to evaluate the helium leakage rate of these three-seam cans.

A supply of helium dissolved in distilled water was prepared by filling a large metal tank with distilled water and connecting the tank to a cylinder of high concentration helium gas $(22.7 \mathrm{ppm})$. The flow rate of gas was adjusted so that helium was continuously introduced into the water at a rate that prevented backflow of air into the system. A diastolic pump was used to circulate the water and promote mixing with helium. This circulation process was continued for several days to allow equilibrium to be obtained.

A large number of \#300 size metal. food cans were then filled with water containing a concentration of helium greater than that of atmospheric helium in water. Cans were filled with 320 nl of water, leaving a headspace volume of $110 \mathrm{ml}$. The cans were then sealed with a hand-operated can sealer. Upon sealing, helium in the water equilibrated with atmospheric helium in the headspace of the cans, thus raising the headspace concentration of helium. The headspace gas in the cans was then sampled at the following intervals: day $O$ (2 hours after filling), day 1, day 2, day 5, day 9, day 16, day 28 and day 51. Results are given in Table 1. 
Table 1. Results from leakage study on metal cans

\begin{tabular}{|c|c|c|c|}
\hline Day and Date & $\begin{array}{l}\text { Elapsed Time } \\
\text { Between Filling } \\
\text { and Sampling }\end{array}$ & $\begin{array}{l}\text { Mean Helium } \\
\text { Concentration, ppb, } \\
\text { He Above He in Air } \\
\text { ( } \pm \text { Standard Deviation) }\end{array}$ & $\begin{array}{l}\text { Number of } \\
\text { Cans Sampled }\end{array}$ \\
\hline Day $0,6 / 26$ & 2 hours & $433( \pm 27)$ & 9 \\
\hline Day $1,6 / 27$ & 24 hours & $346( \pm 11)$ & 9 \\
\hline Day $2,6 / 28$ & 48 hours & $339(t 29)$ & 10 \\
\hline Day $5,7 / 2$ & 120 hours & $359( \pm 24)$ & 10 \\
\hline Day $9,7 / 6$ & 216 hours & $376( \pm 27)$ & 8 \\
\hline Day $16,7 / 13$ & 384 hours & $384( \pm 42)$ & 9 \\
\hline Day $28,7 / 24$ & 672 hours & $349 \ll$ & 9 \\
\hline Day $51,8 / 16$ & 1224 hours & 351 (t & 6 \\
\hline
\end{tabular}


Over the entire test period of 51 days, the helium concentration dropped from a mean value of $433 \mathrm{ppb}$ on $6 / 26$ to $351 \mathrm{ppb}$ on $7 / 16$, which would represent a $12 \%$ loss of helium or 1.6 ppb loss per day. However, this entire loss occurred over the first 24 hour period, day 0 to day 1 ( $433 \mathrm{ppb}$ to $346 \mathrm{ppb}$ ). These results suggest that there may be an error in the measurement of helium values on day 0 , or alternatively, that there is a mechanism by which helium leaks out of the cans during the first 24 hours, but not subsequently. Since it seems unlikely that helium would escape from the cans the first few hours after sealing but show no subsequent loss, an error in measurement would appear to be a more probable cause for these results. It is also perhaps possible that an additional gas was produced inside the can by some unknown chemical reaction within the first 24 hour period, thus causing an apparent reduction in the helium concentration in the succeeding analyses (day 1). This mechanism would not be related to leakage of helium from the cans.

Since the concentration of heliun remained essentially constant from day 1 to day 51 , we conclude that the metal food cans are sufficiently resistant to helium leakage to be used for helium soll gas surveying. During the 1984 survey, samples were collected and analyzed within a relatively short period (20 days). This would further decrease the possibility of leakage.

Coating can seams with silicone rubber sealant as a possible means of further preventing leakage was also, to sone extent, evaluated in this study. While no obvious benefit was found, results from another study (A. A. Roberts, 1984, personal communication) do suggest that silicone rubber sealant can help prevent leakage of heliun from sample containers. This could be of benefit in case a can was not properly sealed by the can sealer. 


\section{APPENDIX B}

Table of Soil Sample Data from the 1984 Copper River Basin Helium Survey

\begin{tabular}{|c|c|c|c|c|c|c|c|c|c|c|c|c|c|}
\hline $\begin{array}{l}\text { SMPL } \\
\text { NO. }\end{array}$ & DATE & TIME & $\begin{array}{l}\text { FIELD } \\
\text { PR. } \\
\text { (in.) }\end{array}$ & $\begin{array}{l}\text { AIR } \\
\text { TEMP. } \\
\text { (C) }\end{array}$ & $\begin{array}{l}\text { SOIL } \\
\text { TEMP. } \\
\text { (C) }\end{array}$ & $\begin{array}{l}\text { MOIS } \\
\text { TURE }\end{array}$ & 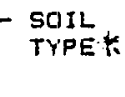 & $\begin{array}{l}\text { CON- } \\
\text { TAINER } \\
\text { PR. (mb) }\end{array}$ & $\begin{array}{l}\text { DEADSP. } \\
\text { YOL. } \\
\text { (EC) }\end{array}$ & $\begin{array}{l}\text { HDSP. } \\
\text { HT. } \\
\text { (in.) }\end{array}$ & $\begin{array}{l}\text { WT. BF } \\
\text { WET } \\
\text { SOIL }\end{array}$ & $\begin{array}{c}\text { WT. OF } \\
\text { DRY } \\
\text { SOIL }\end{array}$ & $\begin{array}{l}\text { HE IN } \\
\text { HDSP } \\
(D P B)\end{array}$ \\
\hline $\begin{array}{l}G 1 \\
G 2 \\
G 3 A \\
63 B \\
64 \\
65 \\
66 \\
67 \\
68 \\
610 \\
611 \\
612 A \\
612 B \\
613 \\
614 \\
615 \\
616 \\
617 \\
618 \\
619 A \\
619 B \\
620 \\
621 \\
622 \\
623 A \\
623 B \\
624 \\
625 \\
626 \\
627 \\
629 \\
629 \\
630 \\
631 \\
632 \\
633 \\
T 1 \\
T 2 \\
634 \\
635 \\
636 \\
637 \\
638 \\
639 \\
641 \\
642 \\
643\end{array}$ & $\begin{array}{l}0803 \\
0803 \\
0803 \\
0803 \\
0803 \\
0803 \\
0803 \\
0804 \\
0804 \\
0804 \\
0804 \\
0804 \\
0804 \\
0804 \\
0804 \\
0804 \\
0804 \\
0804 \\
0804 \\
0805 \\
0805 \\
0805 \\
0805 \\
0805 \\
0805 \\
0805 \\
0805 \\
0805 \\
0805 \\
0806 \\
0806 \\
0806 \\
0806 \\
0806 \\
0806 \\
0806 \\
0806 \\
0806 \\
0813 \\
0813 \\
0813 \\
0813 \\
0813 \\
0813 \\
0813 \\
0813 \\
0813\end{array}$ & $\begin{array}{l}1215 \\
1337 \\
1529 \\
1529 \\
1600 \\
1706 \\
1805 \\
0948 \\
1054 \\
1215 \\
1239 \\
1400 \\
1400 \\
1433 \\
1458 \\
1535 \\
1609 \\
1713 \\
1745 \\
1037 \\
1037 \\
1220 \\
1410 \\
1501 \\
1523 \\
1523 \\
1615 \\
1705 \\
1745 \\
1343 \\
1403 \\
1522 \\
1605 \\
1620 \\
1620 \\
1752 \\
1600 \\
1630 \\
1128 \\
1158 \\
1314 \\
1348 \\
1404 \\
1434 \\
1527 \\
1601 \\
1630\end{array}$ & 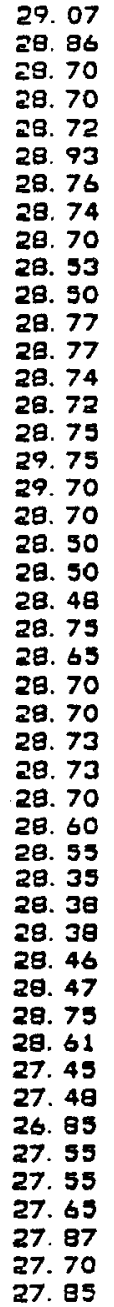 & $\begin{array}{l}22.0 \\
24.0 \\
23.0 \\
23.0 \\
23.0 \\
23.0 \\
22.2 \\
21.5 \\
22.5 \\
23.0 \\
28.0 \\
29.0 \\
29.0 . \\
30.0 \\
28.0 \\
30.0 \\
26.0 \\
30.0 \\
27.0 \\
18.0 \\
18.0 \\
19.0 \\
25.0 \\
24.0 \\
24.0 \\
24.0 \\
24.5 \\
25.0 \\
23.0 \\
30.0 \\
30.0 \\
29.0 \\
29.0 \\
30.0 \\
39.0 \\
28.0 \\
24.8 \\
24.0 \\
22.0 \\
14.0 \\
20.0 \\
19.0 \\
17.0 \\
23.0 \\
19.0 \\
19.5 \\
18.0\end{array}$ & $\begin{array}{r}2.5 \\
9.0 \\
7.0 \\
7.0 \\
9.2 \\
8.0 \\
8.0 \\
7.5 \\
9.0 \\
0.2 \\
3.0 \\
10.0 \\
10.0 \\
0.0 \\
10.0 \\
11.0 \\
1.0 \\
10.0 \\
7.0 \\
3.5 \\
3.5 \\
4.5 \\
10.0 \\
7.0 \\
10.0 \\
10.0 \\
9.0 \\
9.0 \\
12.5 \\
11.0 \\
14.0 \\
14.0 \\
6.0 \\
2.5 \\
4.5 \\
11.5 \\
9.0 \\
7.5 \\
11.5 \\
10.0 \\
10.0 \\
10.0 \\
7.0 \\
5.3 \\
0.0 \\
6.0 \\
4.0\end{array}$ & $\begin{array}{l}M \\
M \\
M \\
M \\
M \\
M \\
M \\
M \\
M \\
W \\
W \\
M \\
M \\
D \\
M \\
M \\
M \\
M \\
M \\
D \\
W \\
M \\
M \\
M \\
D \\
D \\
M \\
M \\
M \\
M \\
M \\
M \\
D \\
M \\
M \\
M \\
M \\
M \\
D \\
D \\
D \\
D \\
M \\
M \\
W \\
M \\
W\end{array}$ & $\begin{array}{c}\text { GBST } \\
\text { GBTS P } \\
\text { T P P } \\
\text { C CT } \\
\text { TS } \\
\text { BTS } \\
\text { CT } \\
\text { GBST } \\
\text { GC } \\
\text { GCG } \\
\text { GT } \\
\text { GT } \\
\text { TC } \\
\text { GS } \\
\text { GST } \\
\text { GBST } \\
\text { TS } \\
\text { BGTS P } \\
\text { GS } \\
\text { G } \\
\text { GBCT P } \\
\text { GTS } \\
\text { GBST } \\
\text { GT } \\
\text { GT } \\
\text { GST } \\
\text { GST } \\
\text { GBTS } \\
\text { GST } \\
\text { GST } \\
\text { GST } \\
\text { GTC } \\
\text { GCS } \\
\text { GR T } \\
\text { GBTS } \\
\text { BST } \\
\text { GBTC } \\
\text { BTS } \\
\text { BST } \\
\text { BSTP } \\
\text { GBTSP } \\
\text { DBCTP } \\
\text { BS } \\
\text { GBST } \\
\text { GTSP }\end{array}$ & $\begin{array}{r}1035.4 \\
1018.7 \\
1007.4 \\
1101.1 \\
1035.3 \\
1032.9 \\
1027.9 \\
1032.2 \\
1012.9 \\
1027.4 \\
1052.0 \\
1004.6 \\
1009.1 \\
1102.1 \\
1043.4 \\
1000.4 \\
973.0 \\
975.4 \\
1016.7 \\
1017.9 \\
1059.0 \\
994.6 \\
1003.7 \\
972.3 \\
1033.3 \\
1020.2 \\
1020.1 \\
1027.1 \\
1020.8 \\
1028.4 \\
960.1 \\
896.3 \\
1010.2 \\
993.8 \\
1005.2 \\
935.7 \\
942.6 \\
1006.3 \\
1011.5 \\
953.9 \\
1000.4 \\
951.9 \\
920.0 \\
1186.4 \\
997.3 \\
960.3 \\
946.2\end{array}$ & $\begin{array}{r}232.0 \\
273.0 \\
273.0 \\
274.0 \\
284.0 \\
303.0 \\
266.0 \\
227.0 \\
271.0 \\
152.0 \\
130.0 \\
318.0 \\
327.0 \\
154.0 \\
263.0 \\
327.0 \\
289.0 \\
306.0 \\
309.0 \\
210.0 \\
163.0 \\
236.0 \\
291.0 \\
299.0 \\
103.0 \\
210.0 \\
304.0 \\
316.0 \\
284.0 \\
317.0 \\
274.0 \\
270.0 \\
266.0 \\
222.0 \\
118.0 \\
271.0 \\
317.0 \\
278.0 \\
235.0 \\
276.0 \\
206.0 \\
265.0 \\
219.0 \\
273.0 \\
53.0 \\
221.0 \\
71.0\end{array}$ & $\begin{array}{l}1.09 \\
1.31 \\
1.19 \\
1.12 \\
0.88 \\
1.16 \\
1.09 \\
1.31 \\
1.12 \\
1.00 \\
1.09 \\
1.09 \\
1.09 \\
1.00 \\
1.00 \\
1.38 \\
1.00 \\
1.16 \\
1.00 \\
1.00 \\
0.84 \\
1.12 \\
1.12 \\
1.16 \\
1.00 \\
1.00 \\
1.16 \\
1.16 \\
1.12 \\
1.00 \\
1.12 \\
1.00 \\
1.00 \\
1.00 \\
1.00 \\
1.06 \\
1.16 \\
1.25 \\
1.38 \\
1.44 \\
1.06 \\
1.00 \\
0.63 \\
1.25 \\
1.00 \\
1.30 \\
0.75\end{array}$ & $\begin{array}{l}579.51 \\
575.72 \\
532.29 \\
525.62 \\
601.12 \\
521.68 \\
590.17 \\
534.12 \\
547.59 \\
730.25 \\
853.45 \\
459.31 \\
449.41 \\
607.80 \\
570.26 \\
386.32 \\
503.08 \\
505.00 \\
461.11 \\
601.12 \\
699.38 \\
583.98 \\
538.32 \\
486.61 \\
741.81 \\
632.28 \\
513.73 \\
485.99 \\
464.61 \\
463.91 \\
579.48 \\
555.17 \\
544.22 \\
627.98 \\
920.45 \\
521.06 \\
432.89 \\
533.49 \\
555.10 \\
535.80 \\
684.22 \\
612.90 \\
597.91 \\
574.50 \\
813.03 \\
644.62 \\
967.92\end{array}$ & $\begin{array}{l}511.30 \\
546.52 \\
484.04 \\
477.71 \\
542.19 \\
499.98 \\
556.15 \\
491.68 \\
495.83 \\
599.65 \\
760.31 \\
434.41 \\
422.51 \\
420.31 \\
551.74 \\
347.81 \\
462.04 \\
477.10 \\
424.40 \\
579.59 \\
563.48 \\
516.65 \\
512.62 \\
467.42 \\
600.91 \\
517.11 \\
495.15 \\
467.42 \\
434.30 \\
464.60 \\
555.39 \\
518.19 \\
480.08 \\
544.71 \\
698.89 \\
465.39 \\
392.22 \\
494.19 \\
448.19 \\
497.11 \\
627.19 \\
510.25 \\
518.15 \\
281.56 \\
683.82 \\
579.60 \\
904.00\end{array}$ & $\begin{array}{r}13 . \\
88 . \\
191 . \\
174 . \\
63 . \\
145 . \\
83 . \\
153 . \\
213 . \\
33 . \\
99 . \\
154 . \\
183 . \\
153 . \\
9 . \\
138 . \\
392 . \\
191 . \\
202 . \\
144 . \\
25 . \\
387 . \\
87 . \\
381 . \\
28 . \\
63 . \\
192 . \\
174 . \\
210 . \\
40 . \\
81 . \\
494 . \\
76 . \\
101 . \\
80 . \\
423 . \\
483 . \\
63 . \\
5183 . \\
5317 . \\
5208 . \\
5404 . \\
5620 . \\
4602 . \\
5731 . \\
5370 . \\
5433 .\end{array}$ \\
\hline
\end{tabular}


APPENDIX B (CONT.)

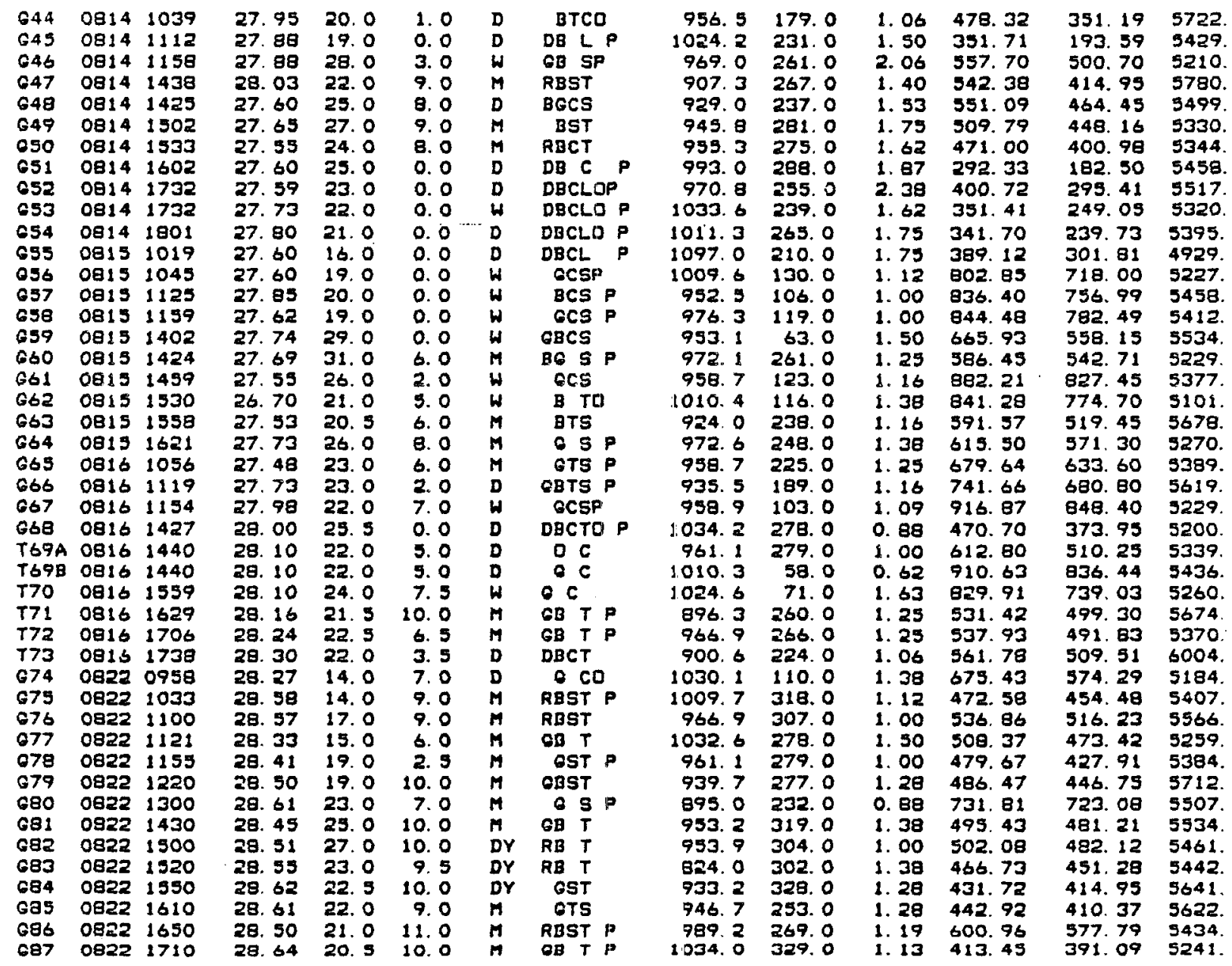

Explanation of soll type symbols: Seven columas are used to colle soll types. Columas and 2 describe the soil sample color: G gray, B = brown, $R$ - red, $O$ - orange, $Y$ - yel:Low, D - dark. For example: grayigh-brown eoil would be coded GB, dark-brown soll would be DB. If a sample has onig one color description (i.e., brown) the

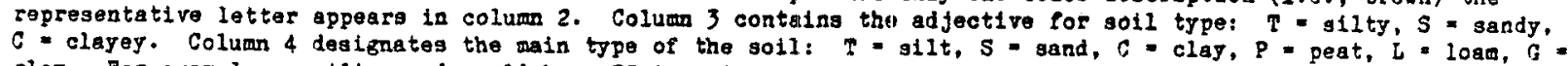
gley. For example, a silty sand would have TS in columns 3 and 4. regpectively. Columns 5-7 contain additional Information about the sample. In colum $5,0=$ organic rlch and $P=$ peaty. Colum 6 would contain either $F=$ fine grained, $P=$ pebbly, or $C=$ cobbly. A "P" in columb 7 indicates permafrost. SolI molsture ts coded as DY = drJ. $D=$ damp, $M=$ moist and $W=$ wet or water-saturated (aud). 


\section{APDINDIX C}

Corrected Data from 1984 Helium Survey

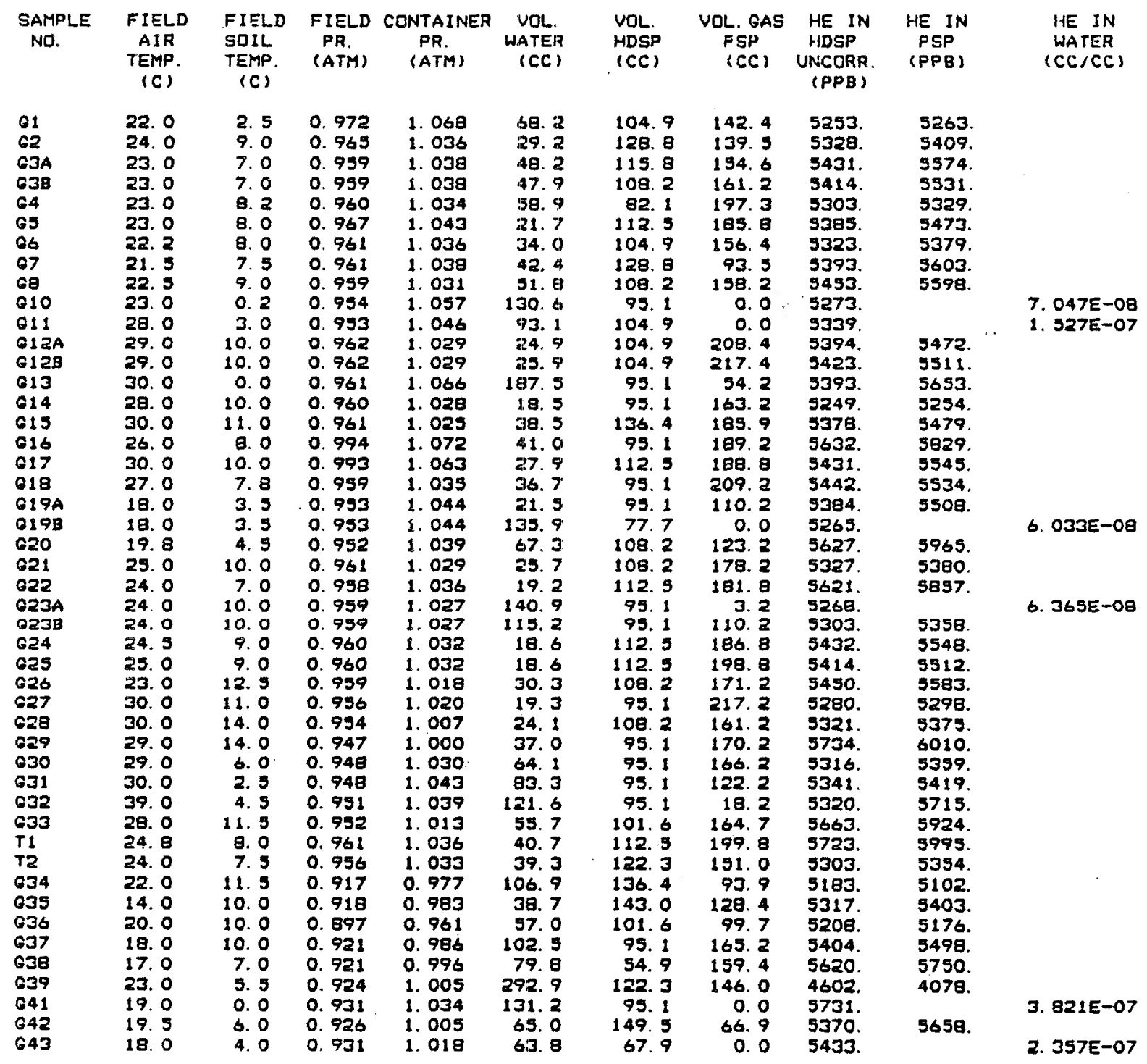




\section{APPENDIX C (CONT.)}

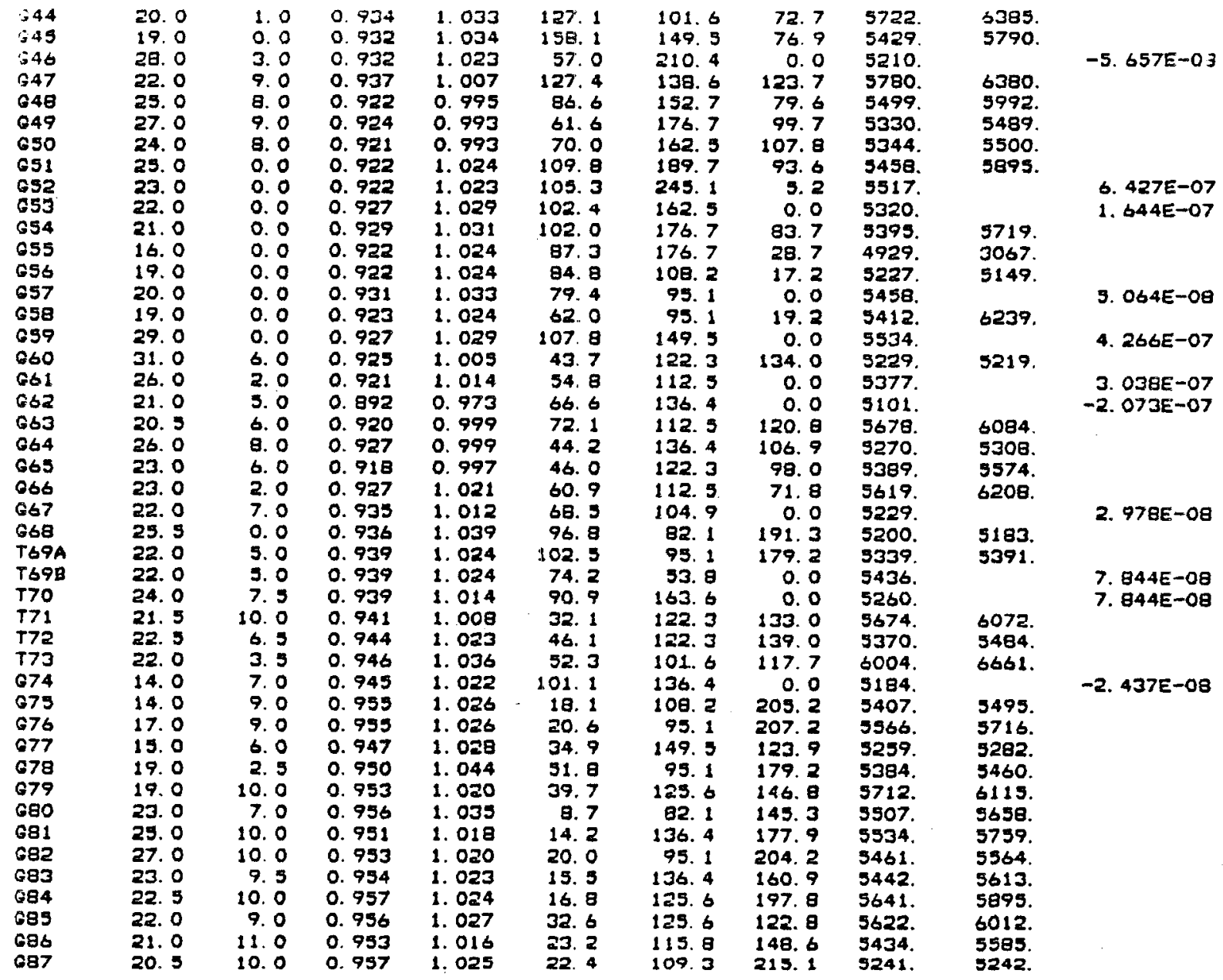

The Henrg's law conatant for the fleld and soil temperaturea was detemined using the following oquation:

$$
\mathrm{K}_{\mathrm{H} \cdot \mathrm{e}}=10.002+4.1939 \times 10^{-2} \mathrm{~T}+1.297 \times 10^{-3} \mathrm{~T}^{-2}-6.6098 \times 10^{-5} \mathrm{~T}^{3}+5.4693 \times 10^{-7} \mathrm{~T}^{4}
$$

Individual Sample Notes: Samples C84G3A and $B$ are duplicates. Collected soll was split between the two cans and an average value for the helfum concentration was ued ln the data analysis. Samples C84G19A and $\mathrm{B}$ repregent two different soil types present at the sampling location. Sample 19B was determined to be vater-gaturated sad its helium concentration was calculated accordingly. Sample $19 \mathrm{~A}$ wa mech drier and ite hellum concentration was determined for the rolume of gaseous pore space present in the sample. Both ralues are reported and used in the data analysis. Clayeg samples C84G23B and C84T69A were very loosely packed into the semple containerg. Samples packed this way would yield very inaccurate values in the determination of gageoue pore spece volumes due to the als pockets enclosed with the sample. Duplicate samples C23A and T69B were collected at each locat1on, but soli was firaly tamped into place wile filing. which flelds a more accurate estiation of pore apace volume. Consequentlj helium concentrations determined for these latter samples were used in the data analyg1s. Sample c84Gi2A may have had a leak in the can seal. A duplicate sample G12B was collected at the same location. Siace the hellum concentration determined for sample G12A mas be suepect, the value determined for 128 was used 1 in data interpretations. 
APPENDIX D

\section{Evaluation of possible: errors in the procedures for calculating helium concentration values}

Error Analysis

The derived equations (Green, 19.84) used for determining helium concentrations in soll pore space molsture assume that the temperature of the headspace gas at the time of sample collection is similar to the air temperature. This is true for many areas of the world. Alaska, due to frequent occurrence of permafrost, is a notable exception. In the Copper River basin, soils were often frozen and measured air temperatures were always significantly higher than soil temperatures. If the headspace gas is cooled before sealing by enclosure in the sample can with the soil, the use of soil temperature to approximate headspace gas temperature should not create significant error.

To examine this further, data sets were generated by manipulation of the container pressures and the equation for calculating the helium concentration In gaseous pore space. These included a) using measured container pressures and soil temperatures only in the equation, b) using measured container pressures, soil temperature and air temperature in seemingly appropriate places in the equation, c) calculating container pressure using air temperatures and using soil and air temperatures in the equation and, d) calculating container pressure using soil temperatures, and using soil temperatures throughout the equation. Container pressures calculated using air temperatures assume that the headispace is not significantly cooled in the can before sealing.

It was found that while the resulting data sets all differ, differences are of ten relative. Thus, while none of the data sets may yield the absolute 
concentrations of helium - thus hindering comparison between surveys - they should still indicate anomalous areas.

Analysis of these data sets alsc revealed questions concerning the measured container pressures and the use of air temperatures in the equations. It was decided to use the data set with container pressures and hellum concentrations calculated using soil temperatures only, since these values seem more indicative of actual concentrations. The use of this data set assumes that the temperature of the headspace gas at the time of can sealing is closer to the temperature of the soil than that of the air, and also assumes no gas production or loss has occurred within the sample container. For sites where additional samples were also collected for analysis by Chemical Projects Ltd., reported results yielded the highest correlation $(R=0.45)$ with this data set.

An analysis of possible errors associated with measured parameters used to determine helium concentrations was conducted to help establish confidence limits for the data. This was done by taking the average or mean values for the varlables that occur in the deterinination of pore space concentrations, including a mean helium in headspace ralue of $5405 \mathrm{ppb}$, and calculating the resultant helium in gaseous pore space concentrations - $5818 \mathrm{ppb}$. Then an estimation of the amount of error associated with each variable was made. Each variable in the equation for calculating the amount of helium in gaseous pore space was then allowed to vary by the estimated amount of error, and new helium in pore space concentrations were calculated. The difference between the mean helium in pore space concentration and the concentration obtained by varying individual parameters according to error estimates was recorded. Finally, the square root of the sum of the squares of the error estimates was calculated to yield an overall estimation of the error associated with the 
typical (mean) helium in gaseous pore space value of $5818 \mathrm{ppb}$. Results are presented in Table 1. The total error estimate ylelds confidence limfts for the mean hellum in soll pore space concentration of $t 135 \mathrm{ppb}$.

Table 1. Differences from mean calculated helium in pore space concentration ( $5818 \mathrm{ppb}$ ) caused by error estimates for the 1984 Copper River basin survey. See Green (1984) for discussion of variables.

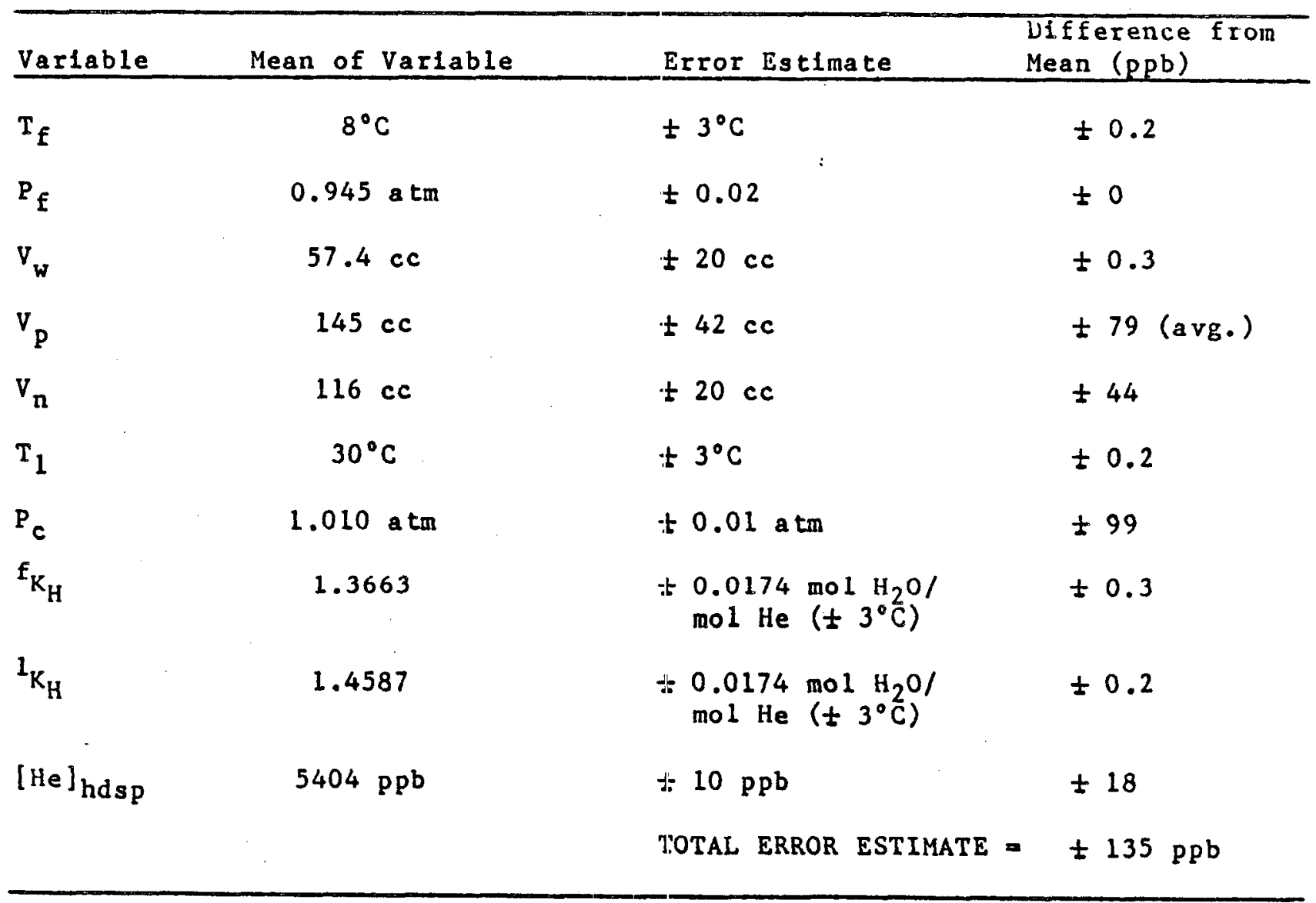




\section{CHAPTER 4}

Mercury Soil Sampling in the Eastern Copper River Basin, Alaska by

Eugene M. Wescott and Donald L. Turner

Introduction

Mercury is found in most rocks in small concentrations. Mercury is highly volatile. Its high vapor pressure makes it extremely mobile, and the elevated temperatures near a geothermal reservoir tend to increase this mobility. The Hg migrates upward and outward away from the geothermal reservoir, creating an aureole of entiched $\mathrm{Hg}$ in the soil above a geothermal reservoir. Such aureoles are typically much larger in area than a corresponding helium anomaly. Volattized $\mathrm{Hg}$ is extremely mobile, and is known to have penetrated at least several hundred meters (about $1000 \mathrm{ft}$ ) of rock overlying base metal ore deposits (McNerney and Buseck, 1975).

Mercury in vapor form will also migrate through hot water, and can be transported by upwelling geothermal waters through faults and fractures. Mercury deposits often occur in regions containing evidence of hydrothermal activity, such as hot springs (White, 1967).

Mercury content in soils has been reported as a geothermal resource indicator by several workers. Matlick and Buseck (1975) confirmed a strong association of mercury ( $\mathrm{Hg}$ ) with geothermal activity in three of four areas tested (Long Valley, California; Summer Lake and Klamath Falls, Oregon). Using the $\mathrm{Hg}$ concentrations in the A horizon of soils on a $1.6 \mathrm{~km}$ spacing interval, they found broad $\mathrm{Hg}$ anomalies outlining the geothermal areas. Phelps and Buseck (1978) also found broad Hg soil anomalies in two other geothermal areas, Yellowstone and Coso Springs, California. Capuano and Bamford (1978) used close-spaced traverses across the Roosevelt Hot Springs, Utah, Known Geothermal Resource Area (KGRA) to define structures controlling 
fluid flow and delineate areas of near-surface thermal activity. Landress and Flusman (1977) also confirmed that anomalous $\mathrm{Hg}$ concentrations were found in $\mathrm{A}$ and $B$ horizons in soil in geothermal areas. Wescott et al. (1981) found very good correlation between $\mathrm{Hg}$ in soils and elevated ground temperatures at Chena Hot Springs, Alaska. Wescott (1981) also investigated Hg vs ground temperatures at $4.5 \mathrm{~m}$ soil depth in the Pilgrim Springs, Alaska KGRA. East (1982) found good correlation between elevated temperatures and soil $\mathrm{Hg}$ at Manley Hot Springs, Alaska. Republic: Geothermal, 1983, used anomalous Hg concentrations in the B-1 soil horizon on Unalaska Island, Alaska to successfully site a geothermal. well.

Thus sampling of soils and analysis for mercury content is a very useful technique for geothermal exploration. Fang (1978) has shown that mercury can be captured by adsorption on clay minerals, by adsorption on iron and manganese oxides and by reactions with organic materials.

The $\mathrm{Hg}$ may become concentrated in one or more of the soil profile layers. The optimum depth of soll sampling in a $\mathrm{Hg}$ soil survey is usually determined by collecting and analyzing soils from three different soil horizons (A-3, B-1, C-1) at the same location (Republic Geothermal, 1983). They found that the B-1 layer was the proper sampling horizon on Makushin Volcano, Alaska. The A-3 soil horizon contains an organic-rich material which caused analytical interference and, on Makushin, the C-1 horizon occurred at unreasonable sampling depths (greater than 3 feet).

In the sampling in the 1984 Copper River basin surveys, we used the $B-1$ horizon wherever the soil profile was developed. The procedure for $\mathrm{Hg}$ surveying starts with collecting the soil samples from the B-1 layer, and storing them in plastic bags. Individual samples are then dried in the shade 
on paper towels, and seived to finer than 80 mesh. The 80 mesh samples were then stored in sealed glass vials until analyzed.

All the samples were analyzed using a Jerome Instruments model 301 mercury detector which uses a thin gold film technique. The detector has a sensitivity of 1 part per billion ( $p p b)$. There is no known constant background level of $\mathrm{Hg}$ in the soil. The background level for a region must be determined from numerous widespread sample measurements.

In 1982 we did not gather soil samples specifically for $\mathrm{Hg}$ testing, but it was our intention to test all the helium soil samples for Hg content. However nearly all of these samples were lost in the return mail to Alaska. Only nine samples taken after the main 1982 field season in the vicinity of the junction of the Tazlina and Copper Rivers were returned and analyzed. We also analyzed a mud sample from lower klawasi mud volcano. The average value of those 10 samples was $31.2 \mathrm{ppb}$, with three samples well above the average. The samples were too few to draw conclusions, but suggested that a comprehensive $\mathrm{Hg}$ survey would be useful in evaluating the geothermal potential of the area.

Results of the $1984 \mathrm{Hg}$ Surveys

$\mathrm{Hg}$ samples were taken at each helium sample site, and at $500 \mathrm{~m}$ (1640 ft) intervals along the electrical self-potential survey lines (Chapter 5). In al1, 129 stations were sampled, some with two or three samples for determination of the proper soil horizon. Fifty two sample sites are located near the Copper River, with most concentrated in a 5 square mile area near the junction of the Copper and Tazlina Rivers. The rest of the sample sites are east of the Copper River with most samples in the vicinity of the two previously defined helium anomaly axeas (Chapter 2). Figure 4-1 shows a histogram of the sample values. These values ranged from 1.4 to $255 \mathrm{ppb}$, with 


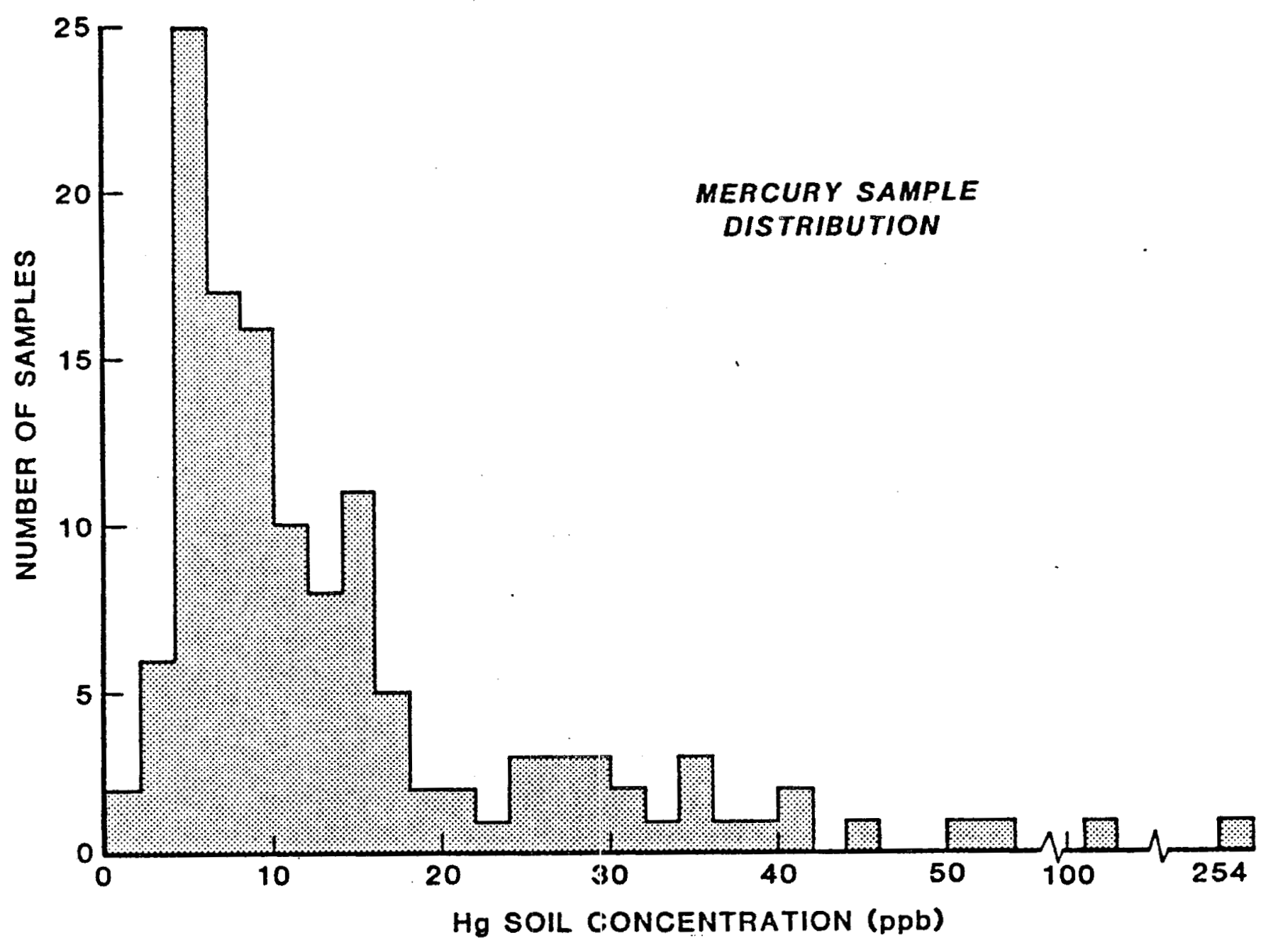

Figure 4-1. Histograin of 1984 mercury soil survey analyses plotted in 2 ppb increments. Mode is $5.5 \mathrm{ppb}$ (determined from 1 ppb increments). 
a mode of 5.5. We used the procedure adopted by Republic Geothernal (1983)

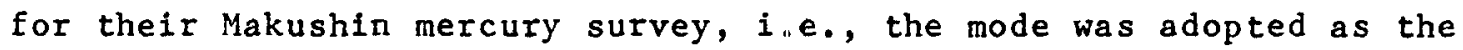
background value and the data were a tranged in groupings of $3 X, 5 X, 7 x$ and greater than $7 X$ background.

Plate 4 shows the sample locations, with symbols representing the various groupings of mercury values. The actual sample values for the various map number stations are given in Table 4-1. Because the area near the confluence of the Tazlina and Copper Rivers was chosen for detalled geophysical and geochemical studies, we have plotted both $\mathrm{Hg}$ and He sampling results on Plate 5, an enlarged air photo of this area.

Discussion of Results

Mercury anomalies are known to result from three types of sources, e.g. geothermal activity, metal/mineral deposits, and human contamination (Republic Geotherma 1, 1983). There are no known metal/mineral deposits in the area surveyed, and the glacial lacustrine sediments covering this area are not likely to contain such deposits. Therefore we need only consider geothermal sources and human contamination as sources of anomalous $\mathrm{Hg}$ concentrations. As shown on Plates 4 and 5 there are several very high $\mathrm{Hg}$ values in the Tazlina area and several tens of samples greater than $5 \mathrm{X}$ background. The correspondence between $\mathrm{Hg}$ and He anomalies (Plate 5) is not one-to-one, but generally the anomalous samples are in similar areas. This might suggest that a geothermal resource exists at an unknown depth beneath the Tazlina area. However, this is an area which has been populated for about 100 years, and human contamination is a likely source of mercury in the soil. The largest concentration, $255 \mathrm{ppb}$, came from a location near several dump sites, and the second largest value was close to one of the oldest residences in this area. Mercury contamination is very likely near a rubbish durap where fluorescent 
Table 4-1. Mercury So11 Concentration Values.

\begin{tabular}{|c|c|c|c|c|c|}
\hline Map No & Fleld No. & $\mathrm{Hg}(\mathrm{ppb})$ & Map No. & Field No. & $H_{g} \quad(p p b)$ \\
\hline 1 & C84G-74M & 8.0 & 38 & C84G-5M & 21.7 \\
\hline 2 & C84G-29M & 5.8 & 39 & C84G-5M & 44.5 \\
\hline 3 & C84G-77M & 3.1 & 40 & C84L104 & 32.8 \\
\hline 4 & $C 84 G-28 H$ & 12.2 & 41 & C84L10OH & 51.1 \\
\hline 5 & $C 84 G-27 M$ & 40.3 & 42 & $C 84 G-25 H$ & 17.2 \\
\hline 6 & C84G-75M & 6.7 & 43 & C84G-4H & 14.3 \\
\hline 7 & $C 84 G-22 M$ & 7.2 & 44 & C84G-6II & 102.1 \\
\hline 8 & C84G-23H & 27.3 & 45 & C84G-3M & 12.5 \\
\hline 9 & C84T-01M & 11.5 & 46 & $C 84 G-4 M$ & 27.8 \\
\hline 10 & $\mathrm{C} 84 \mathrm{G}-76 \mathrm{M}$ & 16.5 & 47 & $\mathrm{CB} 4 \mathrm{G}-80 \mathrm{H}$ & 3.1 \\
\hline 11 & C84G-24H & 5.7 & 48 & C84G-30M & 8.6 \\
\hline 12 & C84G-13H & 14.5 & 49 & $\operatorname{Co4G-31M}$ & 14.4 \\
\hline 13 & C84G-11M & 37.6 & 50 & $C 84 G-32 M$ & 5.8 \\
\hline 14 & C84G-10H & 52.1 & 51 & C84G-33M & 5.0 \\
\hline 15 & C84-9H & 10.8 & 52 & C84G-81M & 5.2 \\
\hline 16 & $C 84 G-12 M$ & 5.8 & 53 & Coิ4ติ-ช5ส & $\hat{1} \overline{7} . \overline{5}$ \\
\hline 17 & C84G-14M & 7.2 & 54 & C84G-84M & 14.9 \\
\hline 18 & C84G-17H & 7.2 & 55 & C84G-86H & 5.0 \\
\hline 19 & C84G-18M & 35.7 & 56 & C84G-83M & 35.5 \\
\hline 20 & C84G-21M & 31.8 & 57 & C84G-87M & 12.2 \\
\hline 21 & C84G-20M & 4.3 & 58 & $C 84 G-73 M$ & 8.8 \\
\hline 22 & $\cos 4-19 H$ & 5.7 & 59 & C84G-71M & 27.2 \\
\hline 23 & C84G-IM & 9.6 & 60 & C84G-70M & 20.9 \\
\hline 24 & C84G-15H & 28.6 & 61 & C84G-69M & 25.9 \\
\hline 25 & $C 84 G-102 M$ & 23.9 & 62 & C84G-68M & 16.8 \\
\hline 26 & $\mathrm{C} 84 \mathrm{~T}-02 \mathrm{M}$ & 5.0 & 63 & $\operatorname{C8} 4 \mathrm{G}-67 \mathrm{M}$ & 4.6 \\
\hline 27 & C84U-1M & 2.9 & 64 & C84G-66H & 8.6 \\
\hline 28 & C84G-7M & 7.4 & 65 & C84G-61M & 7.2 \\
\hline 29 & $C 84 G-2 M$ & 7.4 & 66 & C84G-54M & 39.8 \\
\hline 30 & C84G-16M & 254.6 & 67 & C84G-53H & 4.1 \\
\hline 31 & C84L-103M & 35.8 & 68 & C84G-60H & 29.9 \\
\hline 32 & C84L-101M & 41.0 & 69 & C84G-59M & 17.1 \\
\hline 33 & C84G-79M & 15.7 & 70 & C84G-51M & 7.1 \\
\hline 34 & $\mathrm{C} 8 \mathrm{HW}-\mathrm{M2}$ & 2.9 & 71 & $C 84 H-18 M$ & 25.0 \\
\hline 35 & $\mathrm{C} 84 \mathrm{G}-8 \mathrm{M}$ & 7.2 & 72 & $C 84 G-65 M$ & 4.4 \\
\hline 36 & $C 84 G-6 M$ & 31.9 & 73 & $\mathrm{C} 84 \mathrm{~W}-19 \mathrm{M}$ & 6.4 \\
\hline 37 & $C 84 G-3 M$ & 15.7 & 74 & $C 84 W-17 M$ & 5.0 \\
\hline
\end{tabular}


Table 4-1 Continued

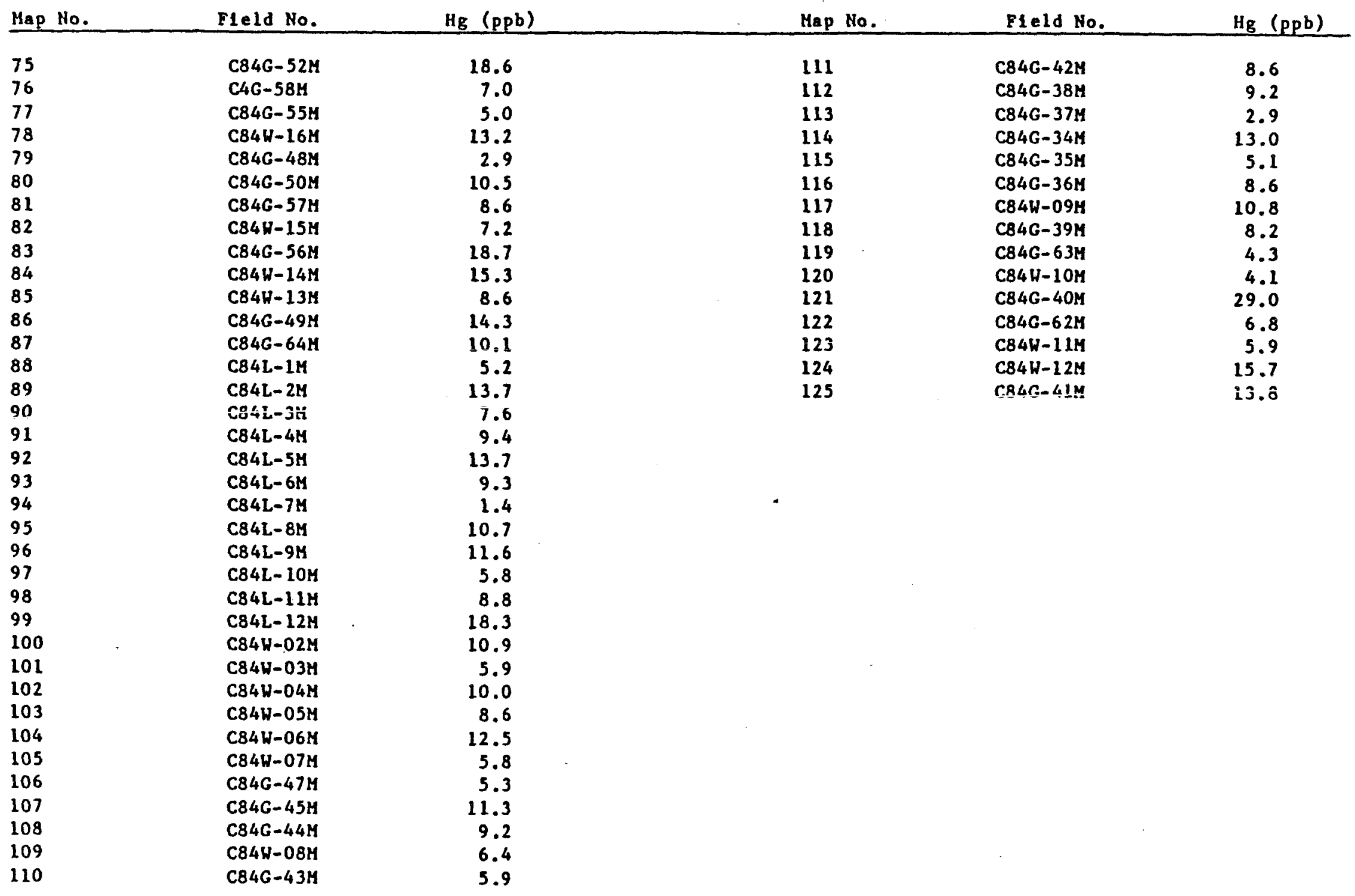


light tubes or thermometers might be discarded. Thus we must conclude that these large values are probably spurious. The smaller anomalies are also suspect, but their possible relationship to geothermal sources cannot be ruled out completely. Unfortunately, we could also possibly have a geothermal source of $\mathrm{Hg}$ overprinted by human contamination.

The areas of interest across the Copper River in the general vicinity of the Klawasi mud volcanoes are much nore remote from human habitation than the Tazlina area. It is highly unlikely that the Hg anomalies shown on Plate 4 in the two general He areas 3 and 5 are due to human contamination. There is one sample greater than $7 X$ background ard several greater than $3 X$ background. There are also some anomalies along the Klawasi River which correspond to He anomalies. The Klawasi River samples are probably in the thaw bulb of the river, and the surrounding permafrost area was not sampled. Thus it is difficult to conclude much about that area. The Klawasi drainage may indicate a NE-trending fault, which could act as a conduit for He and possibly Hg from depth whether there is a geothermal driving force or not.

The moderate $\mathrm{Hg}$ anomalies in the He areas 3 and 5 (Chapter 2, Plates 1 and 2) suggest that these two areas might be underlain by geothermal zones, but because the anomalies are not very large in areal extent or in $\mathrm{Hg}$ concentration, the case for geothermal sources is not strong. 


\section{References}

Capuano, R. M. and Bamford, R. W., 1978, Initial investigations of soil mercury geochemistry as an aid to drill site selection in geothermal systens: University of Utah Research Institute, Earth Science Laboratory Report IDO/78-1701-b. 3.3, $32 \mathrm{p}$.

East, J. 1982, Preliminary geothermal investigations at Manley Hot Springs, Alaska, Geophysical Institute, Univ, of Alaska Report UAG R-290, p. 5255.

Landress, R. A. and Klusman, R. W., 1977, Nature of the occurrence of mercury in solls of geothermal areas: Georgia School of Mines, Dept. of Chem. and Geochem. Final Report, U.S. Geol. Survey Grant No. 14-08-001-G-335, p. 116 .

Matlick, J. S., III and P. R. Buseck, 1975, Exploration for geothermal areas using mercury: a new geochemical technique, In: Proc. Second United Nations Symposium on the Development and Use of Geothermal Resources, v. 1 , p. 785-792.

McNerney, J. J. and Buseck, P. R., 1975, Geochemical exploration using mercury vapor, Economic Geology, v. 68, p. 1313-1320.

Phelps, D. W. and Buseck, P. R., 1978, Natural concentrations of $\mathrm{Hg}$ in the Yellowstone and Coso geothermal fields: Geothermal Resources Council, Transactions, v. 2, p. 521-522.

Republic Geothermal, 1983, Unalaska geothermal project, phase 1B, Final Report Vol. 1 for the Alaska Power Authority, p. 29-36.

Wescott, E. M., W. Witte, A. Dunn and A. Lockhart, 1981. Helium and mercury soil sampling, In: A Geological and Geophysical Study of the Chena Hot Springs Geothermal Area, Alaska, Geophysical Institute Univ. of Alaska Report UAG R-283, p. 54-61.

Wescott, E. M., 1981, Helium and mercury in the central Seward Peninsula rift system, Alaska, In: Geothermal Reconnaissance Survey of the Central Seward Peninsula, Alaska, E. M. Wescott and D. L. Turner, eds., Geophysical Institute, U of Alaska Report UAG R-284, p. 37-59.

White, D. E., 1967, Mercury and base-metal deposits with associated thermal and mineral waters, In: Barnes, H. L., Ed. Geochemistry of Hydrothermal Ore Deposits, Holt, Rinehart and Winston, New York, p. 575-631. 
CHAPTER 5

Self-Potential Surveys in the Eastern Copper River Basin, Alaska

by

Eugene M. Wescott

Introduction

The self-potential, or spontaneous potential, method of geophysical prospecting involves measuring the electrical potential (voltage difference) at points on the ground with respect to a reference point. To minimize spurious electrochemical voltages between the contacting electrodes and the ground, non-polarizing electrodes must be used. These consist of a metal and one of its soluble salts in a concentrated solution such that metal atoms may move reversibly into solution from, or plate onto, the metal electrode in response to an electric field. A copper electrode in a saturated copper sulfate solution contained in a porous cup is the most common electrode. A very high input impedance voltmeter is used to measure the voltage between electrode pairs.

The preferred measurement technique is to use a fixed electrode as a reference point, and a long wire to a second electrode which is moved to stations in a grid in the area to be surveyed. If a large area is to be surveyed, or the terrain or vegetation make the use of a long wire impractical, a pair of electrodes with a shorter separation may be leapfrogged around the area to measure the gradient. By summing the gradient a potential map or profile can be produced.

Self-potential anomalies may be the result of several natural and manmade processes. Conductive deposits of pyrite, pyrhotite, other sulfide minerals, magnetite, covelite and graphite are known to generate selfpotential anomalies which are almost always negative in polarity over the top 
of the body. The conducting body is theorized to serve as a path for electrons from the reducing environment below the water table to the oxidizing zone above. These anomalies are usually confined to a few hundred meters in width and about $10 \mathrm{mV}$ (millivolts) in amplitude. Buried well pipes and pipelines also produce self-potential anomalies by pipe corrosion.

Self-potential anomalies that appear to be related to geothermal activity have been reported from a considerable number of geothermal areas (Corwin and Hoover, 1979). Anomalies range from 50 to $2000 \mathrm{mV}$ in amplitude over distances of $100 \mathrm{~m}-10 \mathrm{~km}$. Their wave forms and polarities vary widely. Steep gradients are often observed over the trace of faults which are thought to act as conduits for thermal fluids. Republic Geothermal (1983) reported 3 selfpotential anomalies near Makushin Volcano, Alaska of $-600 \mathrm{mV},-500 \mathrm{mV}$ and a dipolar anomaly of $t 100 \mathrm{mV}$ amplitude. Subsequent drilling on the $-500 \mathrm{mV}$ anomaly confirmed its geothermal origin.

The flow of water through permeable rocks produces charge separation, and a significant self-potential phenomenon called the electrokinetic origin for large anomalies over hot zones. Zablocki (1976) reported on the results of self-potential field tests in Kilavea, Hawai, and concluded that they were the single most useful geophysical method for identifying and delineating thermal anomalies. He found positive potential differences as high as $1600 \mathrm{mV}$ across distances of a kilometer or less over known fumarolic areas and recent eruptive fissures.

Morrison et al. (1978) found that the voltage - pressure relationship in the electokinetic effect decreases with increasing salinity and increases with temperature. For a saline solution similar to the brine at the important geothermal field at Cerro Prieto, Mexico, a pressure difference of 100 atmospheres at $24^{\circ} \mathrm{C}$ across reservoir core samples would generate a maximum 
potential of $40 \mathrm{mV}$ with the lower pressure side positive with respect to the high pressure side. As temperature fncreased, the potential increased to an expected $200 \mathrm{mV}$ at $300^{\circ} \mathrm{C}$.

Temperature differences also produce self-potential anomalies through thermoelectric coupling (Morrison et al., 1978). A typical coupling coefficient for sandstones is $0.060 \mathrm{mV} /{ }^{\circ} \mathrm{C}$ with the hot side positive with respect to the cold side. For a typical Cerro Prieto core and brine and a $300^{\circ} \mathrm{C}$ temperature difference, $18 \mathrm{mV}$ would be produced by the temperature effect alone.

Potential differences can also be produced by differences in ionic concentrations in the formation fluids amounting to about $25 \mathrm{mV}$ per power of 10 concentration difference (Sill, personal communication, 1982). This can be significant if there are major lateral changes in the ground water.

The Klawasi Mud Volcano Group Self-Potential Surveys (1982)

In 1982 , because of limited field time, self-potential surveys were limited to the area of the Klawasi group of mud volcanoes. A long N-S seismic line located 1.75 miles west of upper Klawasi mud volcano was chosen as the major profile to be made in a search for long period anomalies. Subsidiary profiles were run from the N-S line to upper Klawasi and Shrub mud volcanoes and toward areas of previously determined helium anomalies. A separate profile over lower Klawasi was not connected to the rest of the survey due to time limitations.

Because of the large area involved and the dense vegetation, we chose to use the leap-frog method of surveying, with $100 \mathrm{~m}$ spacing. For almost all of the surveys we set out a $500 \mathrm{ft}$ reference electrode pair which was monitored for telluric current activity. The crew making the S-P survey was informed by radio when the telluric currents were quiet enough for a satisfactory 
reading. Voltages were measured with a Data Precision digital voltmeter of 10 megohm input impedance and a sensfitivity of 10 microvolts. Copper sulfate electrodes were used and selected in pairs to have a residual potential difference of less than $1 \mathrm{mV}$ when imnersed in a common copper sulfate solution. Electrodes were implanted in moist soil by digging a hole through the ubiquitous vegetation mat.

Figure 5-1 and Plate 6 show the map view of the S-P survey lines and potential values (in $\mathrm{mV}$ ). As we had no previous $\mathrm{S}-\mathrm{P}$ data to compare our readings within the area, the baseline value is arbitrary. The N-S profile was extended to the north, and the zero line $A-A^{\prime}$ was chosen near the average values there.

Profile $A-A^{\prime}, 16.8 \mathrm{~km}$ long, is shown in Figure $5-2$. It shows a maximumto-minimum difference of $180 \mathrm{mV}$ over $6 \mathrm{~km}$. There are several shorter period dipolar anomalies of around $50 \mathrm{mV}$. The steepest gradients are located near 2$3 \mathrm{~km} \mathrm{~S}$ and $0-2.8 \mathrm{~km} \mathrm{~N}$ of the base. These steep gradients may indicate the location of fault zones.

Figure 5-3 shows the self-potential profile $B-B^{\prime}$ from line $A^{\prime} A^{\prime}$ east to the summit of Shrub mud volcano. Morrel Hill is the name we gave informally to a hill $2.83 \mathrm{~km}$ north of the base composed of Quaternary moraine deposits. The dipolar $50 \mathrm{mV}$ anomaly from the top of this hill to $0.6 \mathrm{~km}$ east may be significant in terms of a fault zone. However, it may also be a terrain effect as the profile line went rather steeply down the hill and across a stream valley. From there eastward the potential increases gradually to a maximum at $2.1 \mathrm{~km}$ east. Shrub mud volcano itself may represent a small positive anomaly.

Self potential profile C-C' (Figure 5-4) was run westward from the base along an E-W seismic line until progress was stopped by a swamp. At $1.7 \mathrm{~km} \mathrm{~W}$ 


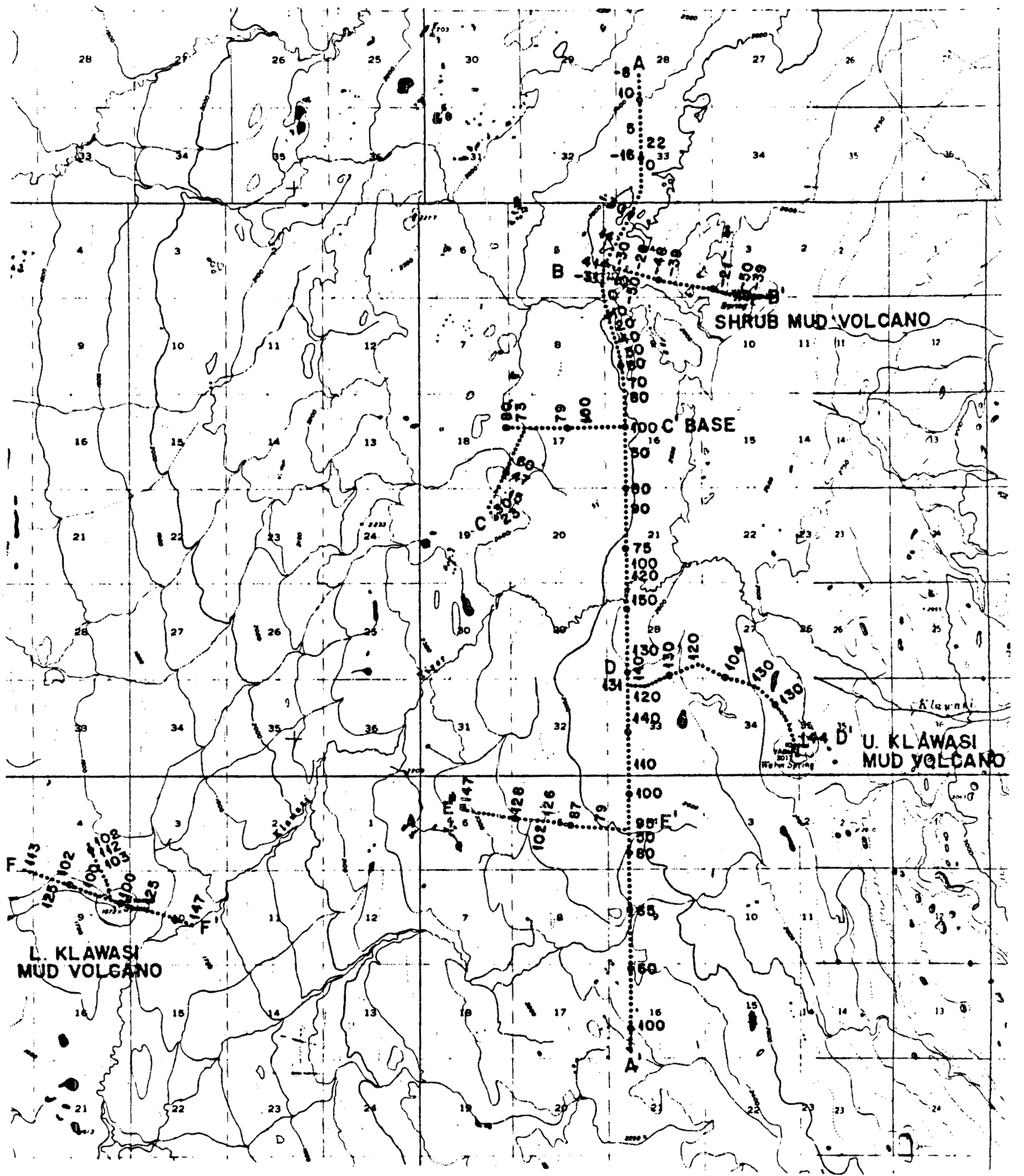

Figure 5-1. Map of 1982 self-potential profiles. Typical potentials in $\mathrm{mV}$. Dots are nominally $100 \mathrm{~m}$ apart; the baseline is arbitrary. 

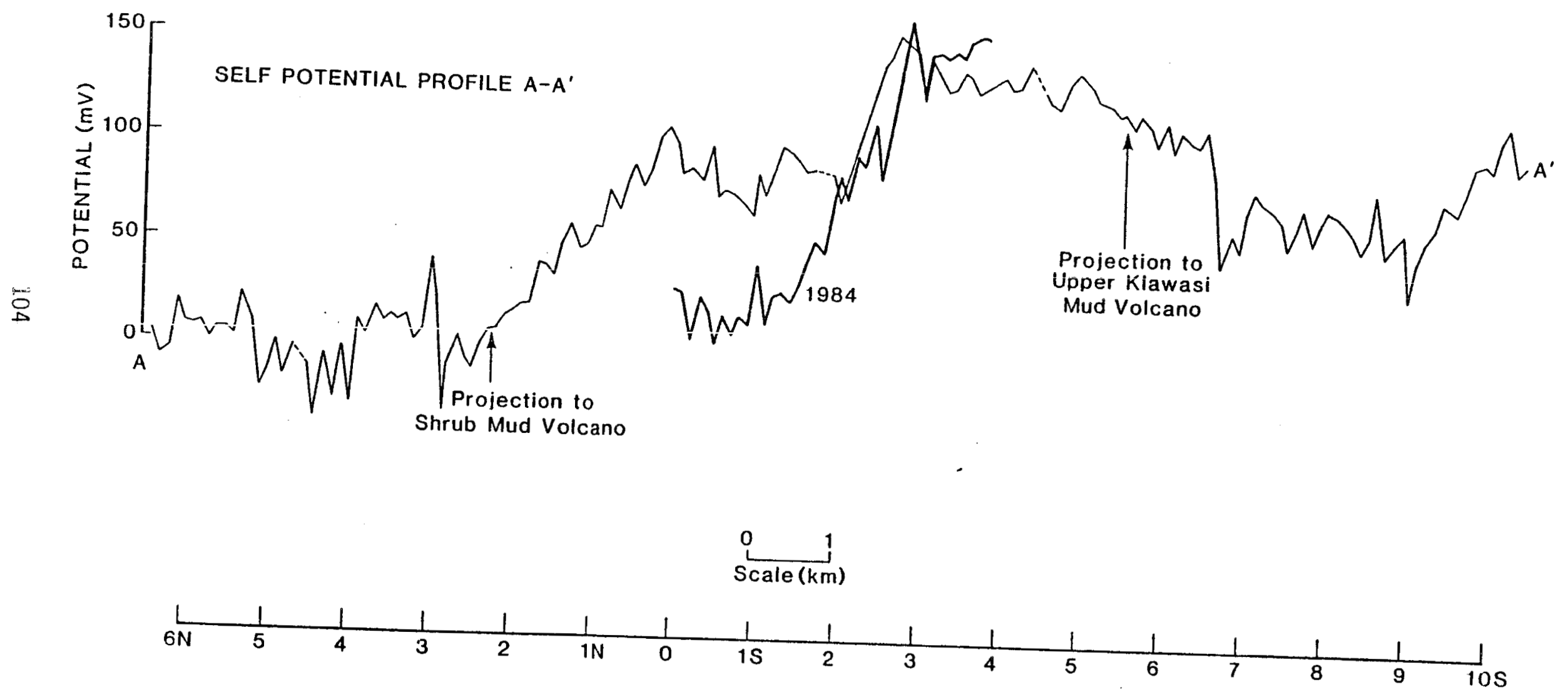

Figure 5-2. North-south self-potential profile A-A'. The major trend is north. The would be produced by a fault crossing near $1.0 \mathrm{~km}$ shown in heavier line. 1984 survey at the same stations is shown in heavier 1ine. The 1984 data show a steeper gradient. 
SELF - POTENTIAL PROFILE B - B' TOP OF MORREL HILL TO TOP OF SHRUB

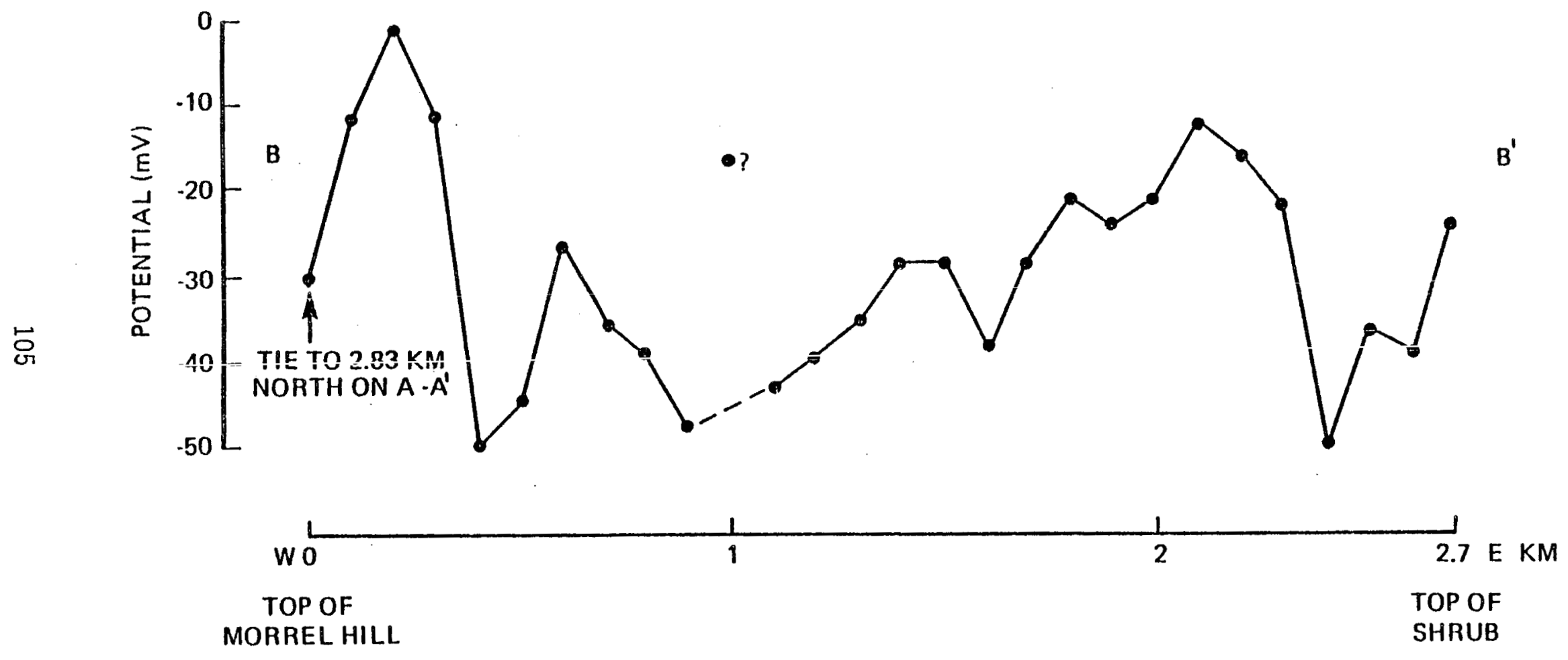

Figure 5-3. West-east self-potential profile $B-B^{\prime}$ from line $A-A^{\prime}$ to the top of Shrub mud volcano. 


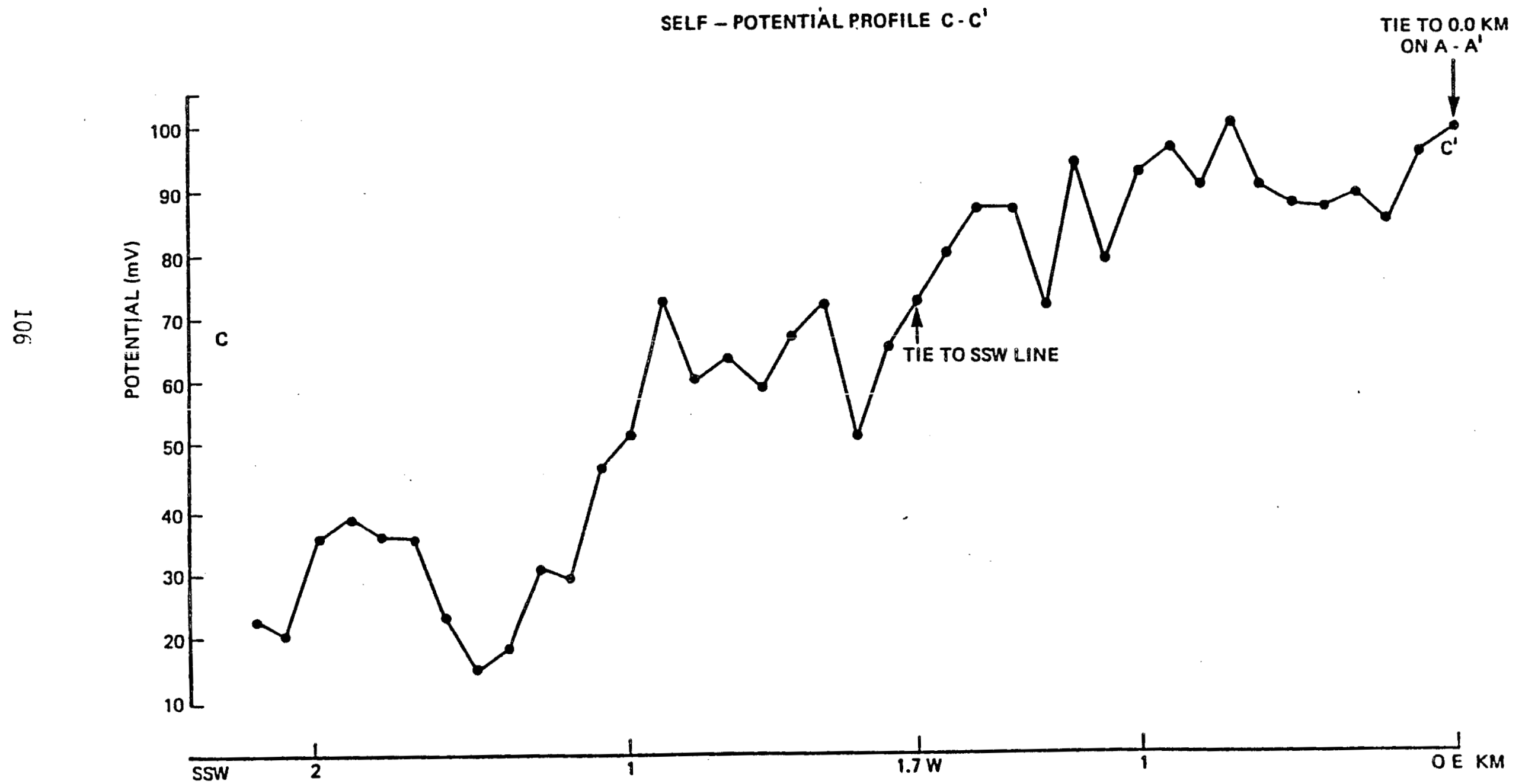

Figure 5-4. Self-potential profile $C-C^{\prime}$ from line $A-A^{\prime}$ west and SSW towards helium anomaly $\# 3$. Potential decreases towards helium anomaly area. 
the profile runs SSW towards helium anomaly 非, but could not be extended further due to a flooding river. In general the trend is negative away from the base, reaching a $90 \mathrm{mV}$ minimum at: $1.4 \mathrm{~km}$ on the $\mathrm{SSW}$ line with respect to the base. As our survey approached the area of helium anomaly 非, further progress was impeded by flooding of creeks in the area. There is a possibly significant dipole-like anomaly of $35 \mathrm{mV}$ with a wavelength of about $1 \mathrm{~km}$ near $1.65 \mathrm{~km}$ SSW. It suggests a fault serving as a conduit for hot water. Profile D-D', (Figure 5-5) starts at $4.2 \mathrm{~km}$ south of the base point and runs $3.8 \mathrm{~km}$ eastward to the top of upper Klawasi mud volcano. From the base line the profile trends gradually to a minimum at $2.2 \mathrm{~km}$ from the top of the mud volcano. There is a steep gradient from $2.2 \mathrm{~km}$ to $1.5 \mathrm{~km}$. Upper Klawasi mud volcano itself does not seem to be a significant $S-P$ anomaly, the profile being essentially flat for $1.5 \mathrm{~km}$ away from the top. The potential at the top is close to the maximum positive potentlal on line $A-A^{\prime}$.

Profile E-E', Figure 5-6, is one of the more important lines which were run. It runs west from $6.6 \mathrm{~km} \mathrm{~S}$ on 1 ine $A-A^{\prime}$ toward the general area of

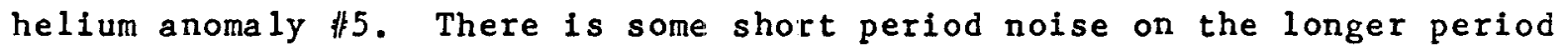
trends. From line $A-A^{\prime}$ the trend is constant for $1.1 \mathrm{~km}$ where a positive gradient begins. A maximum of $147 \mathrm{mV}$ was reached at $2.8 \mathrm{~km}$ from $\mathrm{A}-\mathrm{A}^{\prime}$, close to the maximum value on line $A-A^{\prime}$ nears $3 \mathrm{~km}$ south of the base. The positive gradient to $+147 \mathrm{mV}$ near the north edge of an area with a helium anomaly and a +2.7 mgal gravity anomaly is considered significant as discussed in the gravity and summary chapters.

Profile $F-F^{\prime}$ was run across lower: Klawasl mud volcano to see if there was a significant S-P anomaly from the active flow of mud and gas to the surface. As seen in Figure 5-7 the profile from the summit down to the base of the mud slope at the edge of the vegetation at $1.1 \mathrm{~km}$ west is very flat. 


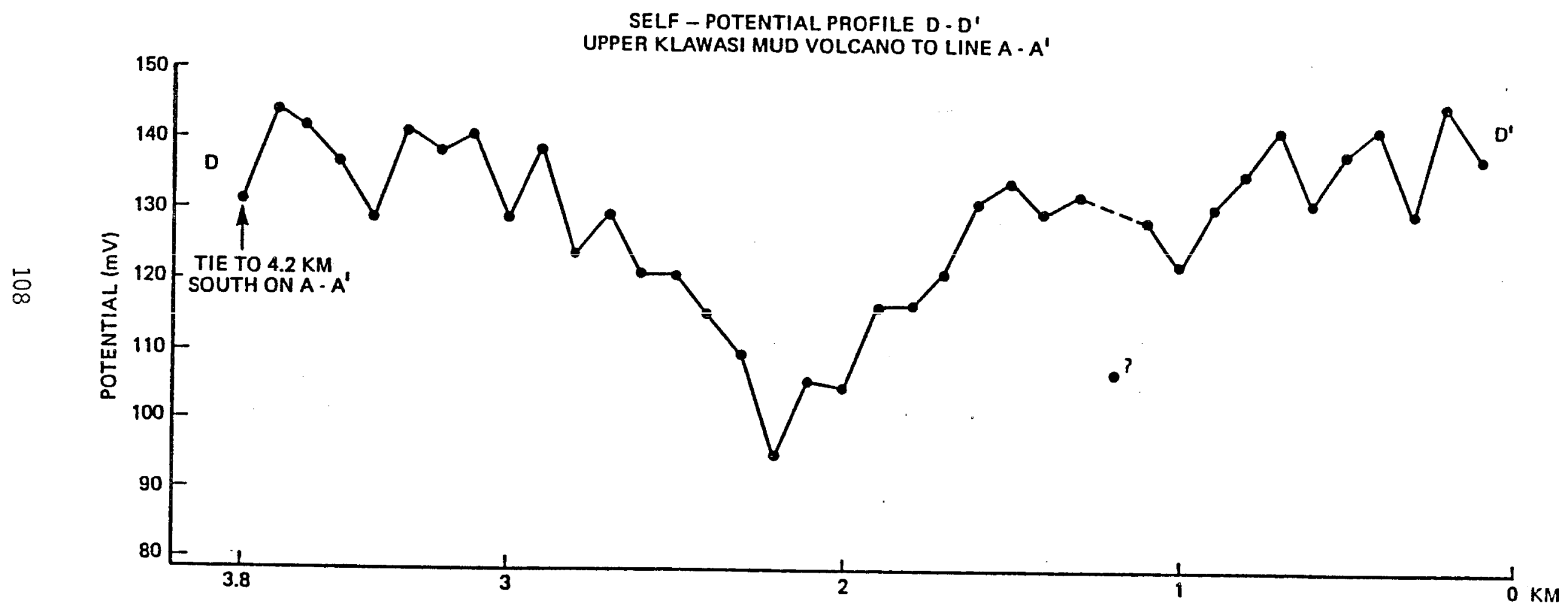

Figure 5-5. Self-potential profile D-D' from the line A-A' to the top of Upper Klawasi mud volcano. Note that the mud volcano does not seem to be a significant S-P anomaly. 


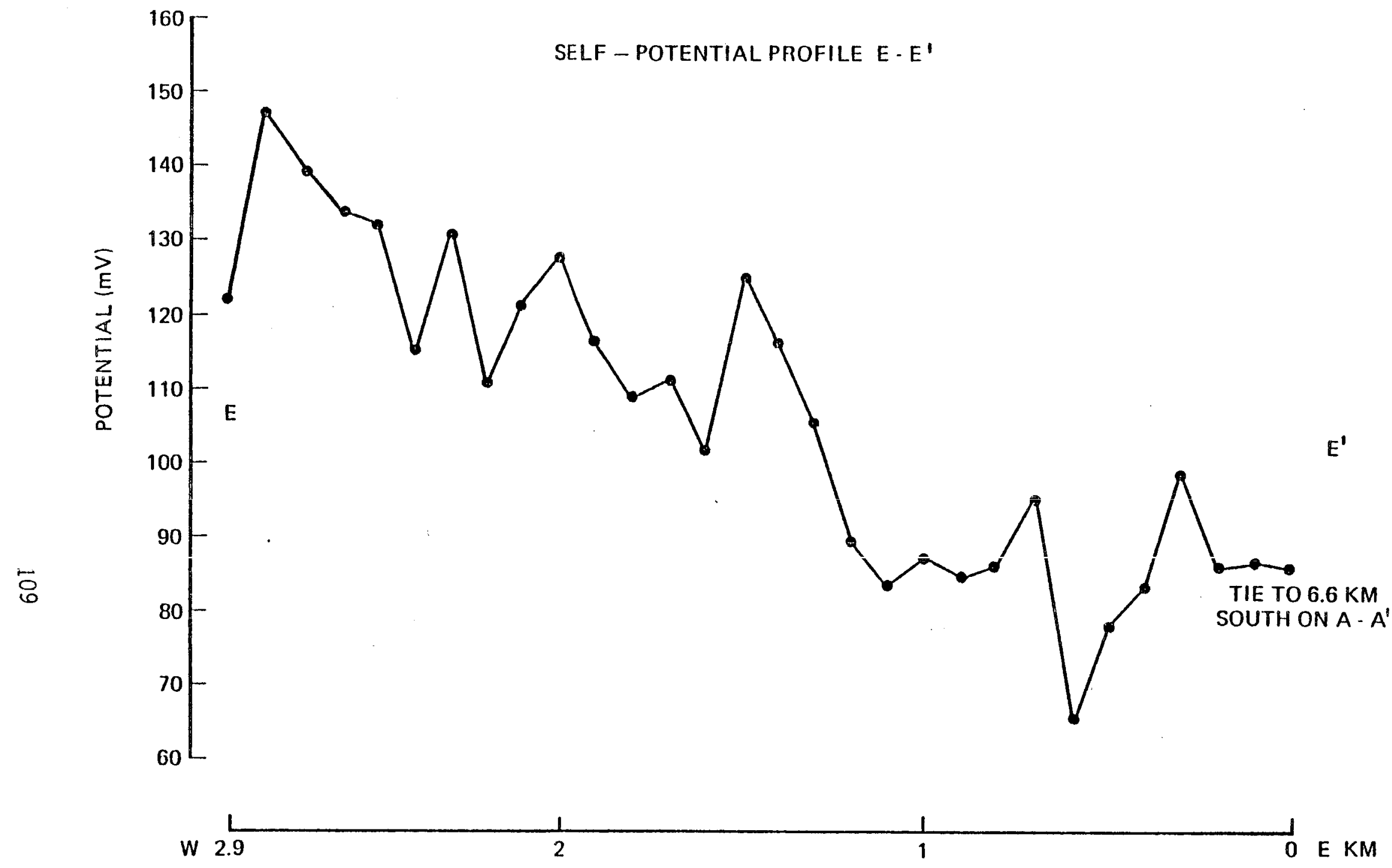

Figure 5-6. Self-potential profile $E-E^{\prime}$ west from line $A-A^{\prime}$ towards positive gravity-helium anomaly \#5. The potential increases towards the anomaly area. 
SELF - POTENTIAL PROFILE F - F'

ACROSS LOWER KLAWASI MUD VOLCANO

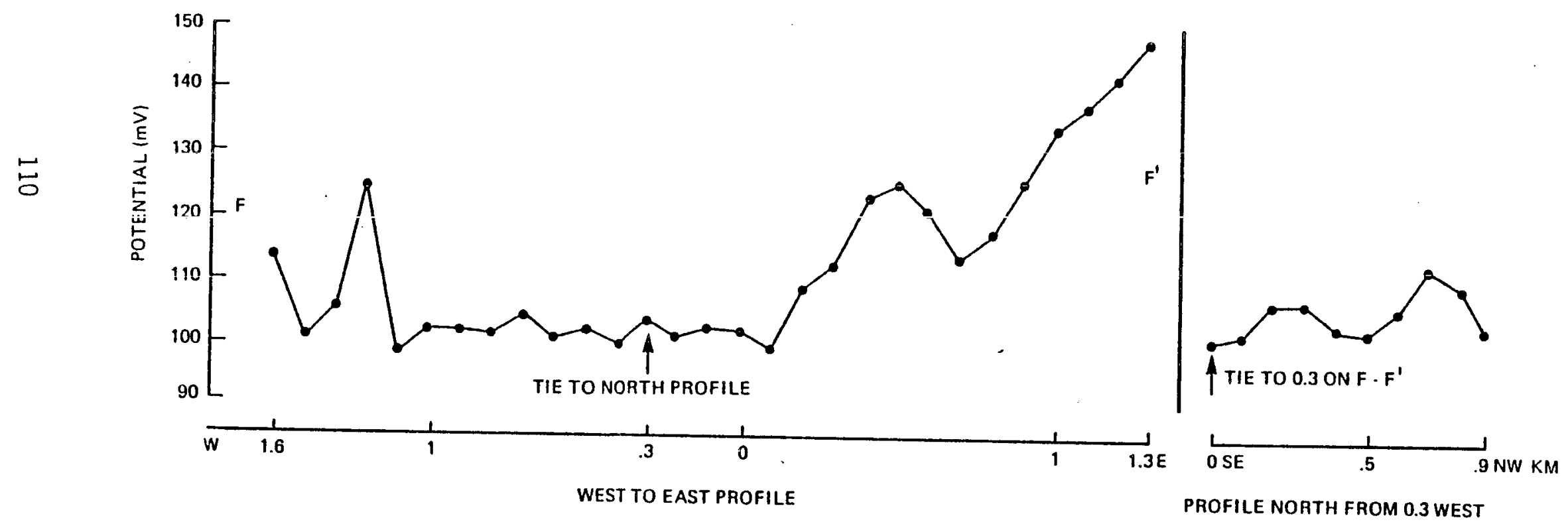

Figure 5-7. Self-potential profile $F-F^{\prime}$ across Lower Klawasi mud volcano. The flat area is the area of devegitated recent mud flow. The potential gradient is steeply positive towards the east. 
At the contact between the mud flow and the taiga vegetation there is a $25 \mathrm{mV}$ anomaly and an apparent positive trend to the west. To the east of the summit the trend is generally positive with respect to the arbitrary summit baseline. At $1.3 \mathrm{~km}$ east the potential difference is $47 \mathrm{mV}$. Unfortunately the line could not be extended to tie in with line E-E' due to the end of the 1982 field season. We note, however, that the potential was increasing toward helium anomaly 非 (Plate 1$)$. A short line northwest from $0.3 \mathrm{~km}$ west of the summit is also shown in Figure 5-7. Again on the mud flow the S-P is almost constant. This may be a result of the high conductivity of the mud, as the spring water is quite saline. The resistivity of the mud was measured in 1984 as $0.157 \Omega-m$. 1984 Self-Potential Surveys

The purpose of the self-potential survey work in 1984 was two-fold. The He anomaly area neat the Tazlina River had not been surveyed at all in 1982 , so a complete S-P survey of the area was needed. In the He anomaly areas 3 and 5 in the Klawasi area (Plate 1), the previous S-P survey had not been extensive enough to produce a contour map, and the two He anomalies had not been adequately covered. Thus further S-P surveying in the anomaly areas was needed, as well as other S-P lines to re-do the previous survey, and tie various parts together.

Two methods were used, the fixed reference electrode/long-wire technique, and the leap-frog summed potential method. In both methods the telluric current activity was monitored on a $32: 8 \mathrm{ft}(100 \mathrm{~m})$ fixed reference electrode pair, and readings were only taken during quiet periods. Copper-copper sulfate non-polarizing electrodes were used, and the potential differences were read with with a Data Precision digital voltmeter. 


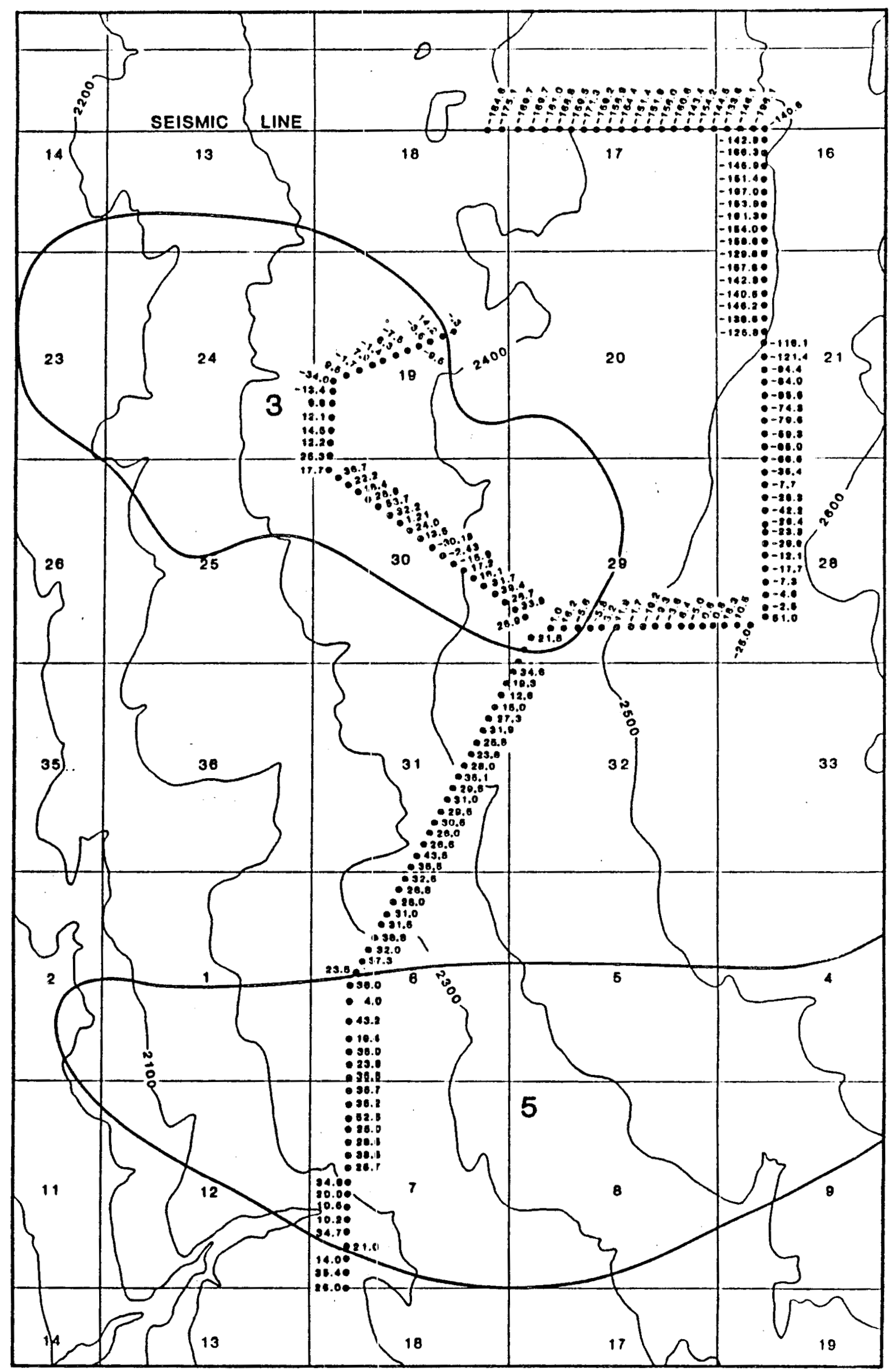

Figure 5-8. $\quad 1984$ self-potential survey in Klawasi mud volcano area. Values in millivolts. Combined helium anomaly areas 3 and 5 are also outlined (see Plate 2). 
Tazlina Results. The Tazlina area survey was done in two time periods: The first week and the last two days of the field season. Over 11 line miles were surveyed. The soil near the surface just below the organic mat was slightly molst-to-dry during the survey, as the period was essentially free of precipitation. The Tazlina S-P results have been contoured wherever possible on Plate 5, and where lines are too is solated to contour, the values are indicated. S-P stations were $328 \mathrm{ft}(100 \mathrm{~m})$ apart for most of the survey lines, but were $300 \mathrm{ft}$ on a few lines. Because the Tazlina River was too wide to span with a wire, the survey net could not be closed from one side of the river to the other, and was only tied together via the Tazlina River Bridge. Zero potential was arbitrarily choser as the base station near the NW corner of the ball field at the old Copper Center School (Plate 5).

In the Tazlina area the self-potential ranges from +180 to -78 millivolts. There is a fairly large negative area straddling the Tazlina River centered about $2400 \mathrm{ft}$ NW of its junction with the Copper River. This low is surrounded on the $\mathrm{E}$ and $\mathrm{N}$ by highs of +100 to $+140 \mathrm{mV}$ areas. Another low of $-38 \mathrm{mV}$ is located about $2500 \mathrm{ft}$ to the NNW of the river low. A sharp gradient was discovered in a distance of 100 yds along the Copper River, about $500 \mathrm{ft} S W$ of the $R$. in Copper River on Plate 5 . In general the spatial wavelength of the anomalies in the Tazlina area is about $2500 \mathrm{ft}(760 \mathrm{~m})$. Klawasi Results. The Klawasi S-P survey covered 10.5 line-miles $(16.8 \mathrm{~km})$ as shown on Figure 5-8, with stations spaced every $328 \mathrm{ft}(100 \mathrm{~m})$. A generally N-S line was surveyed linking the 1982 He anomaly areas 3 and 5 (Plate 1). It was hoped that the northern end of the line could be extended to tie with an S-P line running east along a seismic line in section 17 . However deep flooding in section 19 thwarted the effort, as it had thwarted the 1982 attempt to run a line south from the E-W seismic line. The S-P 
profile has been plotted in Figure 5i-9. The approximate boundaries of the 1982 He anomaly areas 3 and 5 have been shown on the figure.

A second line was surveyed east from a base station in Sec. 29 to intersect the N-S seismic line, and the 1982 profile A-A', Figures 5-1 and

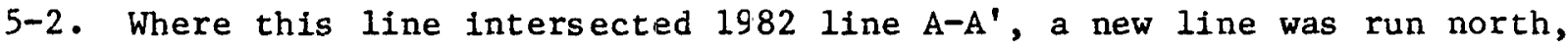
using the same electrode stations as in the previous survey. The 1984 results have been plotted to the same scale as line $A-A^{\prime}$ on Figure 5-2. The 1984 profile shows a steeper gradient than the 1982 profile.

An additional line was run west from the intersection of the $\mathrm{N}-\mathrm{S}$ and $\mathrm{E}-\mathrm{W}$ seismic lines (section 16), as shown on Figure 5-8. Discussion of 1984 Results

The Tazlina survey revealed some fairly large S-P anomalies with horizontal wavelengths of about $2500 \mathrm{ft}$. By rule of thumb, if $x_{1 / 2}$ is the total width of an S-P anomaly at half the negative maximum, then the depth to the top of the anomaly source is of the order of half this distance, (Telford et a1., 1976). According to Telford et al. (1976) this estimate may be valid to $\pm 100 \%$. In the Tazlina area, the negative anomaly across the Tazlina River (Plate 5) has a half width $\mathrm{x}_{1 / 2}$ of about $1000 \mathrm{ft}$, implying a depth to top of source of $500 \pm 500 \mathrm{ft}$. The other negative anomaly about $1000 \mathrm{ft}$ north of the Tazlina River has a similar wavelength and depth estimate. Thus it is implied that the source of these anomalies is either fairly shallow, or at least extends to fairly shallow depths. The anomaly amplitudes are large enough to be considered significant, and possible geothermal indicators. Our experience indicates, however, that differences in soil types and soil moisture content can produce anomalies of nearly these amplitudes. Soil type and moisture differences were noted during the S-P surveying, so the suggestion that a geothermal resource may be present cannot be very firm. However, the largest 


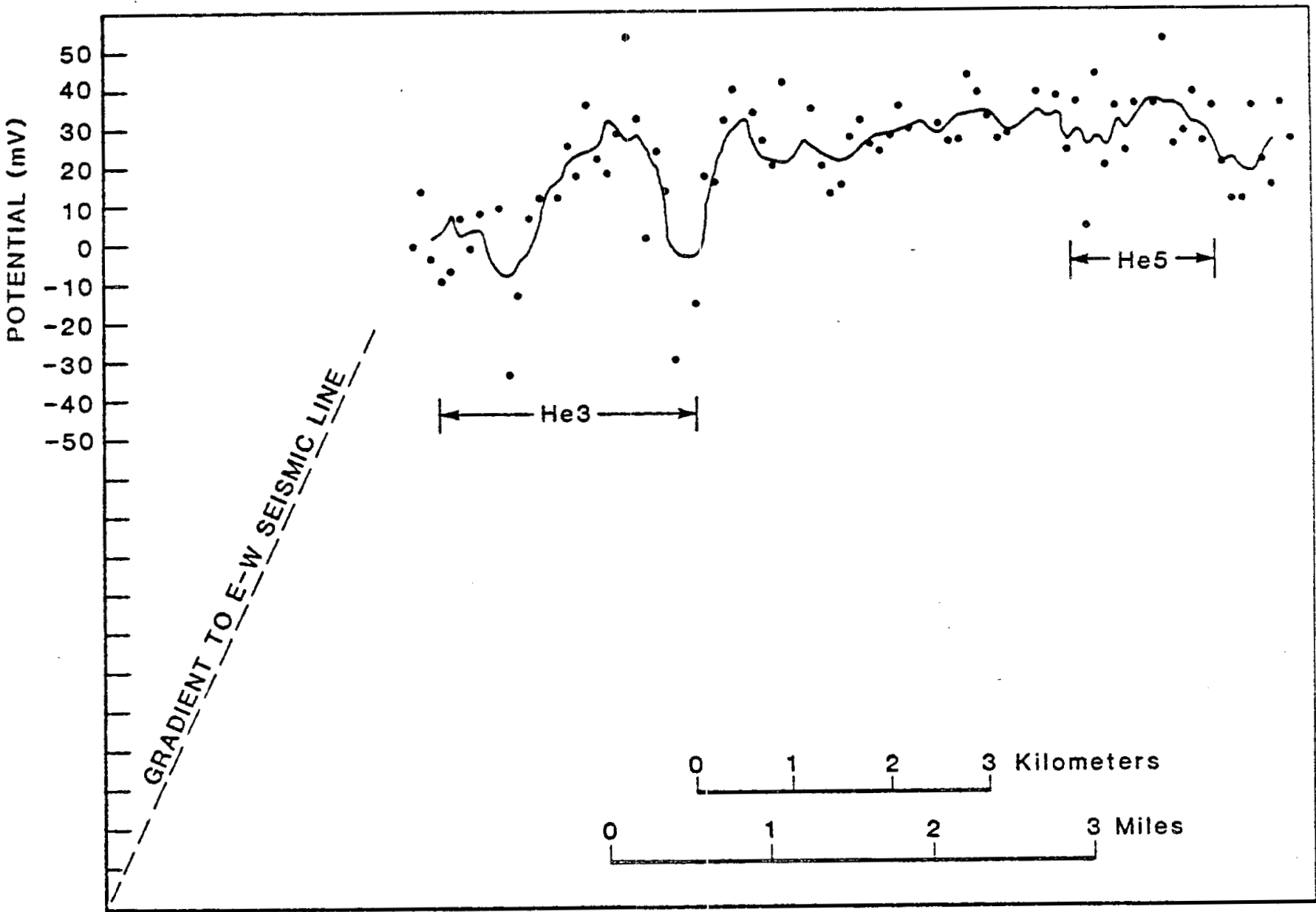

Figure 5-9. 1984 self-potential survey profile between helium anaomaly areas 3 and 5 (Plates 1 and 2). Profile is essentially flat and featureless. 
anomalies can be seen to correspond fairly well with Hg and He anomalies.

The Klawasi profiling of 1982 and 1984 cannot be directly compared because differences in soil moisture and underground water flow from time to time will change the self-potential distribution.

The 1982 lines did not directly cross He anomalies 3 and 5 (Plate 1). However lines $C-C^{\prime}$ and $E-E^{\prime}$ went close to anomalies 3 and 5 respectively. These lines indicated that anomaly 3 was tending to negative while anomaly 5 was tending positive (Figures 5-4 and 5-6). They also suggested a potential difference of $130 \mathrm{mV}$ might be present on a hypothetical traverse from 3 to 5 .

In 1984 such a traverse was made, and the results are plotted in Figures 5-8 and 5-9. The profile is rather flat and featureless. There is no particular anomaly associated with the He anomaly $\# 5$, but there may be a small anomaly associated with the boundaries of 3 . This line could not be extended across the broad, flooding river to tie with the line coming west on the seismic line. The dashed line on Figure 5-9 shows what the average gradient would have to be to tie the line. The fairly steep gradient is the reverse of the 1982 measured profile from the E-W seismic line to the vicinity of the $N$ side of the flooded area. However the profile measured in 1984 along the N-S seismic line compared to profile A-A' (1982) shown in Figure 5-2 shows a much more negative potential along the $\mathrm{N}$ end of the line in 1984 than 1982 , so the potential reversil is reasonable.

The steep gradient along $A-A^{\prime}$ (Figure 5-2) between $3.5 \mathrm{~S}$ and $3 \mathrm{~N}$ seen in the 1982 survey, and an even steeper gradient over the portion of the line resurveyed in 1984 is the most interesting feature of the S-P data. It suggests a dipolar anomaly of over $200 \mathrm{mV}$ amplitude, with a long wavelength. It is in fact similar in amplitude and wavelength to the S-P anomaly found by Corwin and Hoover (1979) at the economically important Cerro Prieto geothermal field 
in Baja California. By this comparison we do not imply that a geothermal resource equivalent to Cerro Prieto exists under this area of the Klawasi survey. If the S-P anomaly seen along A-A' is due to convection along a fault, the fault would cross $A-A^{\prime}$ at about station $2 N$, as illustrated in Figure 5-10. We have not found helium or mercury anomalies in the area of the $S-P$ anomaly. 


$$
\text { Copper } A-A^{\prime}
$$
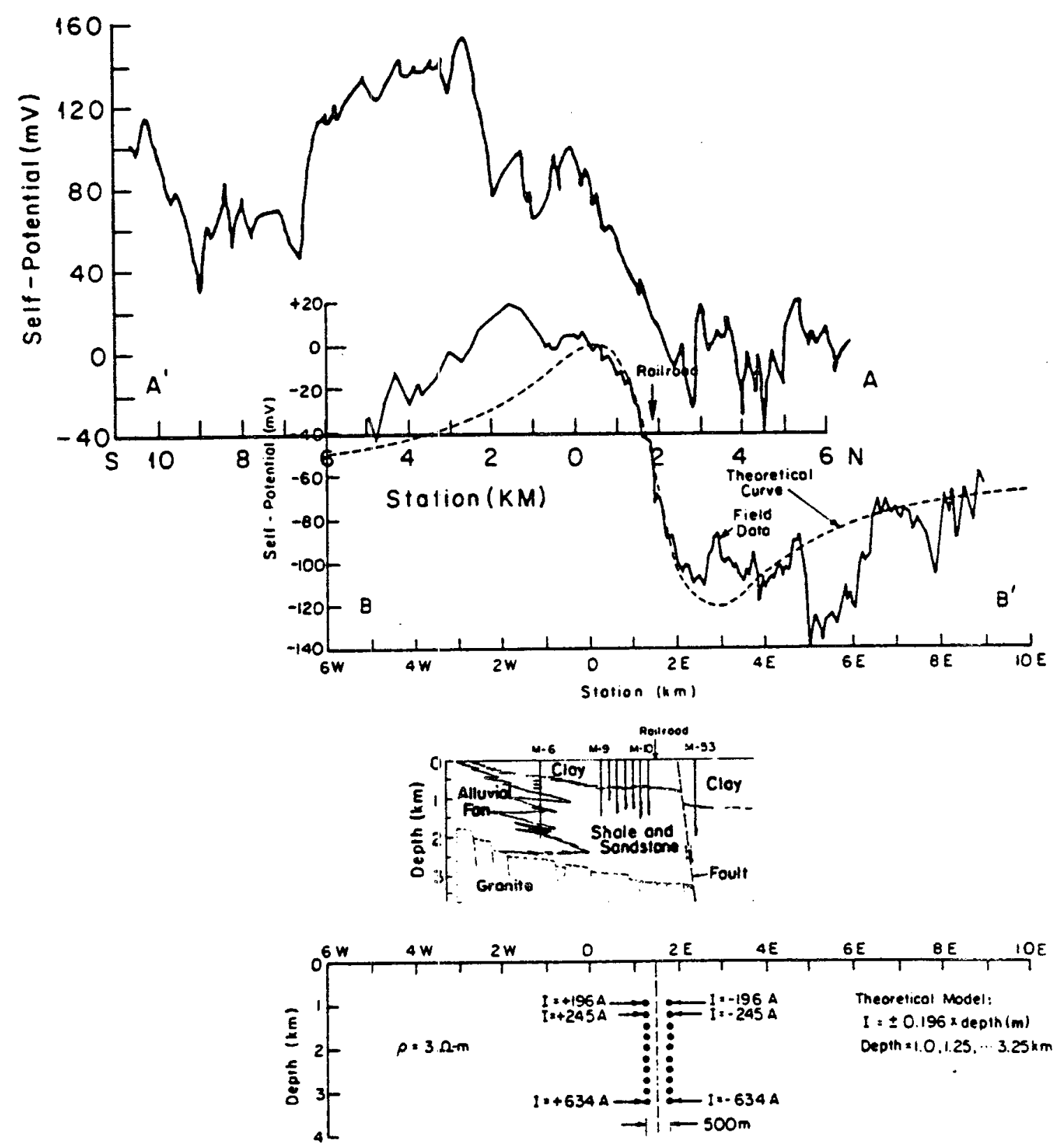

Figure 5-10. Comparison of S-P profile A-A' with an S-P profile across the Cerro Prieto geothermal field plotted to same scale. Top: profile, Copper Basin A-A'. Second from top: Cerro Prieto, observed data solid lines and dipole fault model dashed. Third from top: geological cross section of Cerro Prieto. Bottom: Electrical model for line B-B', Cerro Prieto. Cerro Prieto data from Corwin and Hoover (1979). 


\section{References}

Corwin, R. F. and D. B. Hoover, 1979. The self-potential method in geothermal exploration, Geophysics, $44(2): 226-245$.

Morrison, H. F., R. F. Corwin, G. de Moully and D. Durand, 1978. Semi-annual technical progress report, contract 14-08-0001-16546, Univ. of California, Berkeley.

Zabloski, C. J., 1976. Mapping thermal anomalies on an active volcano by the self-potential method, Kilauea, Hawaii: Proc. 2nd. U.N. Symposium on the Development and use of Geothermal Resources, San Francisco, CA, U.S. Govt. Printing Office, Washington, D.C., 2:1299-1309.

Republic Geothermal, 1983. Unalaska Geothermal Project, Phase 1B Final Report, for The Alaska Power Authority, 1:67-70. 
A Gravity Survey of Part of the Eastern Copper River Basin, Alaska by

Eugene M. Wescott, Becky Petzinger, William Witte, Donald L. Turner, and Gary Bender

Introduction

A regional gravity survey (Barnes, personal communication, 1982) and a more detailed survey by Isherwood (personal communication, 1982) have indicated possible structures associated with the Klawasi mud volcanoes. The Isherwood data contoured at I mgal intervals (Chapter 1, Figure 1-4) show a gravity low associated with lower Klawasi and several other interesting features. These data, however, are not sufficient to make definitive models.

A more detailed gravity survey, with a station density of about 1 station per square mile, was planned for 1982 in the area of the eastern Copper River Basin. A gravity survey in itself cannot provide direct evidence of geothermal resources. However, in conjuction with other measurements, gravity maps are useful in interpreting structures which may be related to geothermal resources.

After variations in gravity due to latitude and altitude are removed, the variation of the densities of the rocks and their configuration produce the remaining anomalies of interest. The density of rocks depends upon their mineral composition, porosity and age to some degree. In general the most recent sediments tend to have the lowest densities while older, more deeply buried sediments are more dense due to compaction and/or cementation. Crystalline basement rocks and intrusives tend to have even greater densities. An excess of mass beneath the surface will produce a gravity high while a greater thickness of low density rocks 
wil1 produce a gravity low.

Physical Property Measurements

A number of rock samples from volcanic flows on Mt. Drum and greenstone units near Chitina were collected and measured for density and magnetic susceptibility. The volcanic rocks varied considerably in density, from 2.43 to $3.08 \mathrm{gm} / \mathrm{cc}$, with an average value of 2.61 . The greenstones had an average density of $2.98 \mathrm{gm} / \mathrm{cc}$. In contrast, the surface mud from upper and lower Klawasi mud volcances averaged $1.80 \mathrm{gm} / \mathrm{cc}$. The values which are given in Table 6-1 can be compared with the previously published values cited in Chapter I (Ancireasen et al., 1964).

\section{Gravity Survey}

The 1982 gravity survey was made using a Worden gravity meter no. 491 with a sensitivity of 0.10078 mgals per scale division. The gravity data are given in Appendix A. We used $\varepsilon$ gravity base station on a concrete gasoline pump pedestal across the road from the Copper Center Lodge, with a given value of $981,931.85 \mathrm{mgals}$ and an altitude of $1015 \mathrm{ft}$ (Barnes, personal communication, 1982). Wherever possible gravity was read at bench marks and VABM stations. At most of the stations, however, altitude control was provided by up to four American Paulin System Altimeters. Unfortunately all were found to have inclependent drifts. After careful calibration at bench marks and use of temperature corrections, two altimeters were chosen which gave the least and most consistent drifts. One was used as a base station for barometric correction and the other was carried in the helicopter. Temperature and barometric records from the FAA station at the Gulkana airport were also used in calculating corrections for the altimeter readings. 


$$
\text { Table 6-1 }
$$

Physical Property Determinations

Sample No

DT82-7A

DT82-1B

OT82-2A

DT32-2B

DT82-4

DT82-3

DT82-5

DT32-6A

DT82-5B

DT82-7A

DT82-7B

\section{A}

B

c

Upper K1awasi mud Lower Klawasi mud

$$
\begin{gathered}
\text { Magnetic } \\
\text { Susceptibility }
\end{gathered}
$$

Description

Porphyritic hornblende

plagioclase andesite

1765

2.57

680

2.54

1254

2.43

Fine-grained, vesicular, non-porphyritic basalt

1326

2.47

II

622

3.08

11

1299

2.58

1231

2.54

Porphyritic pyroxene plagioclase andesite

1730

2.64

1475

2.57

1219

2.62

"I

1102

2.67

Greenstone - probably me ta-basalt

7613

2.93

1319

3.01

5700

3.00

48

1.82

clay size " mostly

(n)

1.78 
The 1:63,360 scale topographic maps of the area were found to have many errors in topographic features, and were used only generally to check on the accuracy of the altimeter readings. Station locations were determined from air photos and later placed on the maps. 1984 Gravity Survey

In 1984 we had planned to carry out a detailed gravity survey in the vicinity of the Tazlina area where a 1932 helium anomaly was found. We also had planned to carry out additional gravity survey work in the vicinity of the gravity high between upper and lower Klawasi mud volcanoes. The additional work near Klawasi was determined to be unnecessary after we were permitted to examine the more deta:Lled proprietary gravity data by Amoco 0 il $\mathrm{Co}$. , and found that our map agreed very well.

We did additional gravity work in the Tazlina area. Thirty two gravity stations were occupied, generally at locations of helium soil samples. Altitude control was by means of a Paulin altimeter, corrected for barometric and temperature changes. The gravity data were obtained with a LaCoste-Romberg gravimeter, using; the same base station as the 1982 survey.

The results were disappointing in that the altimeter appears to have been malfunctioning and the measured altitudes differ significantly from the topographic map elevations at a number of stations. We calculated the complete Bouguer anomaly using a density of 2.4 and using two sets of altitude data: the calculated altimeter values and values estimated from the topographic map. The altimeter derived Bouguer map shows a variation of $3.67 \mathrm{mgal}$ in about a mile distance near the Tazlina and Copper River junction, while the topographic map data show only $2.40 \mathrm{mgal}$. The two contour maps differ significantly, and we have reluctantly concluded that the data 
are unusable. We have therefore not incorporated the 1984 data with the 1982 results.

Results and Interpretation

Plate 7 shows the complete Bouguer anomaly contours based on our stations (solid circles), the survey stations of Isherwood (crosses, personal communication, 1981) and stations by Barnes (open circles, personal communication, 1982). For the Bouguer and terrain corrections we at first used the commonly used density value of $2.67 \mathrm{gm} / \mathrm{cc}$ (correction to a sea level datum surface). However, inspection of the density log of the Amoco Ahtna A-l well (Chapter 1) shows that this value is too high. A density of 2.4 is appropriate to a depth of $3500 \mathrm{ft}$. Therefore, another complete Bouguer anomaly map was prepared using the 2.4 value. The effect of the density change was to reduce the regional west-to-east gradient. The important shorter wavelength anomalies are similar on both versions. The complete Bouguer anomaly map (Plate 7) shows three large scale features. There is an almost semi-circular negative pattern in the eastern half of the map, which appears to be related to the large negative Bouguer anomaly of Mt. Drum, about 8 miles east of the edge of the map. In the northwest quadrant of the map there is a positive anomaly of about $18 \mathrm{mgals}$, which is probably indicative of a structural high in the crystalline basement rocks. South of the positive anomaly is an east-west-trending negative trough.

There are a number of interesting snaller scale features superposed on the Mt. Drum negative regional trend. A negative anomaly of $2 \mathrm{mgals}$ is centered over Mineral Springs (lower Klawasi mud volcano). There are also negative anomalies of the order of 1 mgal 2 miles south, and 3 and 5 miles northeast of lower Klawasi mud volcano. 

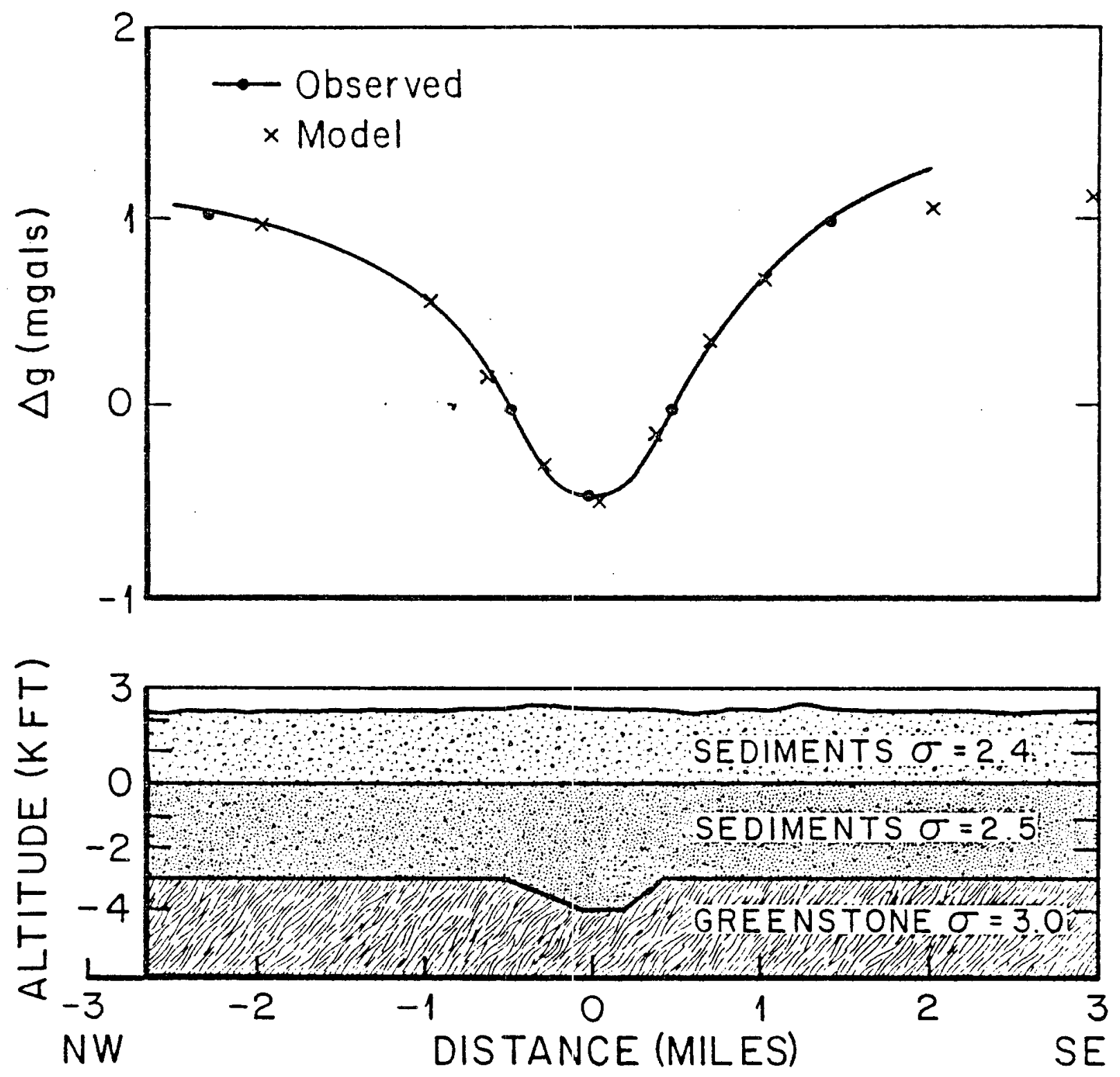

Figure 6-1. Top: Gravity anomaly profile NW-SE across the gravity through running generally between Lower Klawasi and Shrub mud volcanoes - solid line. Bottom: Model cross section, no vertical exaggeration, of a bedrock valley or graben structure which would explain the anomaly. Model values are shown on profile by $x$ 's. 
A positive closed anomaly is located about half way between upper and lower Klawasi mud volcanoes. This area is of considerable interest because it coincides exactly with helium anomaly no. 5 (Chapter 2, Plates 1 and 2).

In order to isolate the smaller scale anomalies, the regional gravity trend due to $M t$. Drum was removed by subtracting a third degree trend surface from the $\sigma=2.4$ complete Bouguer anomaly map. The results are shown in Plate 6 . The most prominent feature revealed by removing the regional trend due to $M t$. Drum is a northeast-trending trough from lower Klawasi to Shrub mud volcano. At lower Klawasi the trough either bends westward or intersects another linear trough. There are several lows along and adjacent to the trough. It is possible that the trough delineates an old fault zone which has been buried by glacial lake sediments. It is also possible that this zone of weakness has allowed over-pressured mud to rise along the fault system, to form mud diapirs, and also to reach the surface occasionally as mud volcanoes. However, these hypothetical diapirs would have to be broad and very long. Another, perhaps more likely, model for the trough is a sediment-filled valley (either erosional or stmuctural) in the dense basement rocks. Figure 6-1 shows a generalized NW to SE gravity profile across the trough and a two-dimensional model which fits the data. The model incorporates a mile-wide depression in the greenstone basement $1000 \mathrm{ft}$. in depth. This could be interpreted as a graben or an erosional valley.

The isolated gravity high between lower Klawasi and upper Klawasi mud volcanoes lies at the end of a gravity ridge in line with the east-west gravity trough. This isolated high can be modelled as a dense intrusive. Figure 6-2 shows a cross section model using a density contrast +0.3 gm/cc 

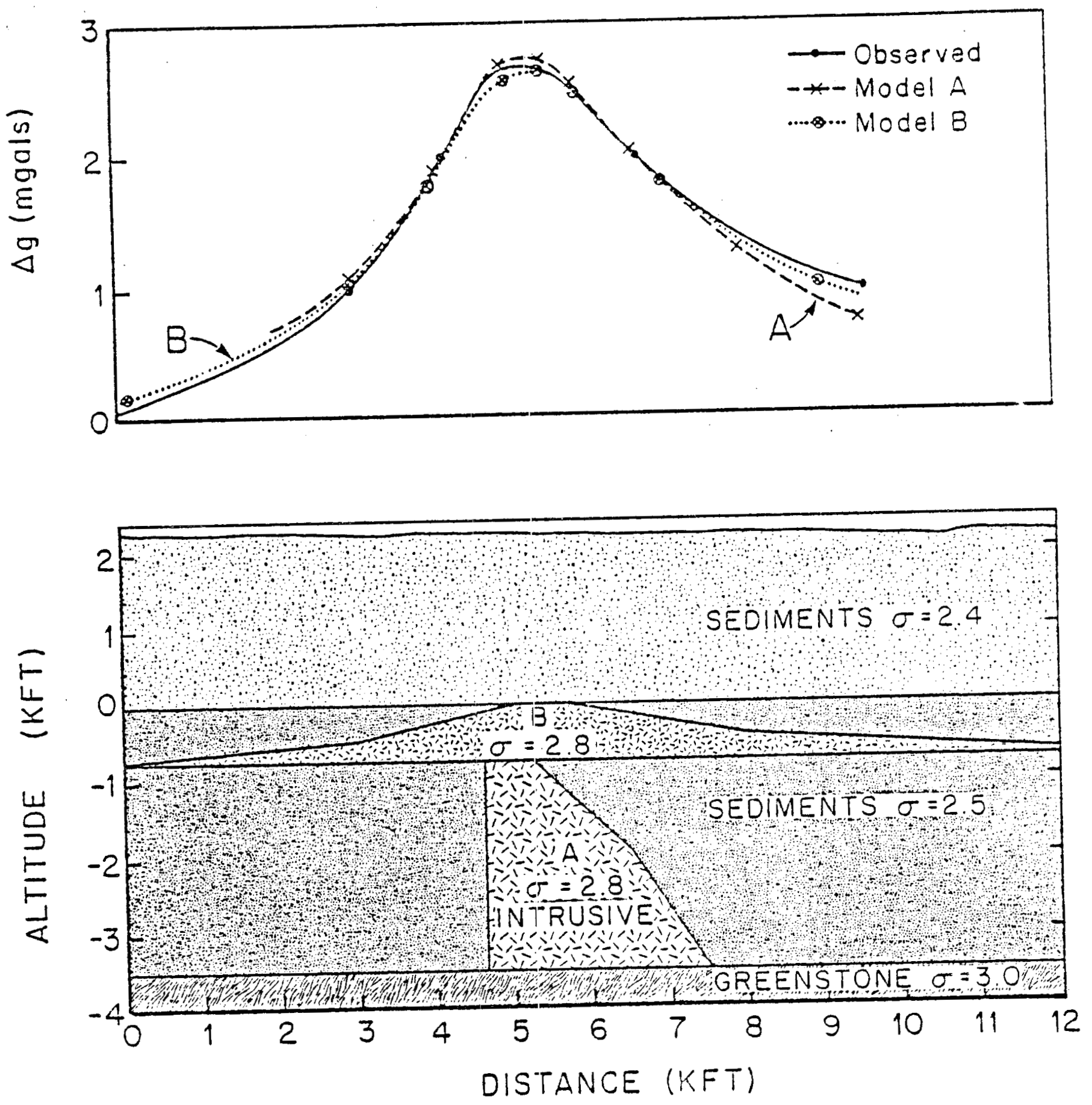

Figure 6-2. Top: N-S gravity profiles across positive gravity anomaly at helium anomaly 非. Solid line - observed, dashed line - model A, dotted line - model B. Bottom: Cross section of molols, A deep Intrusive, $B$ - shallow lacolith intrusive. 
which fits the data well. Model A is an ellipsoidal intrusive about $3 \mathrm{X}$ as wide as its thickness with a depth to its top of $3000 \mathrm{ft}$. This model is almost a maximum depth model for a density contrast of 0.3 . Model B is a mushroom shaped laccolith at a shallower depth which also gives a close fit to the data. Motyka (personal communication, 1982) has calculated that a molten intrusive similar to model $B$ would cool in about 20,000 years.

Without some other type of geophysical data there is no way of determining a unique model for the observed gravity data. The positive gravity anomaly coincides with an area of lower than average total field magnetic anomaly, and is also coincident with the 1982 helium anomaly area no. 5 (Chapter 2, Plates 1 and 2). This situation suggests that the area could possibly be a geothermal prospect. Geothermal fluids have a tendency to alter magnetite and other magnetic mineral components of rocks chemically to non-magnetic alteration products. In addition to these indicators, the 1982 self-potential traverse E-E', Figure 5-6 shows a positive gradient in the direction of the anomaly, again possibly suggestive of a geothermal resource area.

The gravity low about $8 \mathrm{~km} \mathrm{NE}$ of lower Klawasi mud volcano is also of considerable interest. It coincides fairly well with the 1982 large helium anomaly 3 (Chapter 2, Plates 1 and 2). This negative gravity anomaly also corresponds with an east-west negative trend in the magnetic maps, possibly suggesting geothermal alteration of magnetic minerals. 


\begin{tabular}{|c|c|c|c|c|c|c|c|c|c|}
\hline Station & Lat1 tud & & Longltud & & Elevation (ft.) & $\underline{F M}$ & $\begin{array}{l}=2.67 \\
S B A \\
\end{array}$ & $\begin{array}{l}0=2.67 \\
\mathrm{CBA} \\
\end{array}$ & $\begin{array}{c}0.2 .4 \\
C B A\end{array}$ \\
\hline $\begin{array}{l}\text { CUCE } \\
\text { GMI } \\
\text { GML }\end{array}$ & $\begin{array}{l}61^{\circ} 57^{\circ} \\
62^{\circ} 03^{\prime} \\
62^{\circ} 03^{\prime}\end{array}$ & $\begin{array}{l}17^{\prime \prime} \\
31^{\prime \prime} \\
29 "\end{array}$ & $\begin{array}{l}145^{\circ} 17^{\circ} \\
145^{\circ} 13^{\circ} \\
145^{\circ} 13^{\circ}\end{array}$ & $\begin{array}{l}07 " \\
22^{\prime \prime} \\
17 "\end{array}$ & $\begin{array}{l}1015.0 \\
1856.6 \\
1860.0\end{array}$ & $\begin{array}{l}-40.01 \\
-27.89 \\
-28.03\end{array}$ & $\begin{array}{l}-74.62 \\
-91.19 \\
-91.45\end{array}$ & $\begin{array}{l}-74.62 \\
-91.01 \\
-91.27\end{array}$ & $\begin{array}{l}-71.06 \\
-84.62 \\
-84.87\end{array}$ \\
\hline $\begin{array}{l}\text { GMA } \\
\text { GM5 } \\
\text { GM6 } \\
\text { GM7 } \\
\text { GMB } \\
\text { GM9 }\end{array}$ & $\begin{array}{l}62^{\circ} 03^{\circ} \\
62^{\circ} 03^{\prime} \\
62^{\circ} 03^{\prime} \\
62^{\circ} 03^{\circ} \\
62^{\circ} 03^{\prime} \\
62^{\circ} 03^{\prime}\end{array}$ & $\begin{array}{l}45^{\circ} \\
42^{\circ} \\
29^{\circ} \\
52^{\circ} \\
05^{\circ} \\
19^{\prime \prime}\end{array}$ & $\begin{array}{l}145^{\circ}-14^{\prime} \\
145^{\circ} 13^{\prime} \\
145^{\circ} 12^{\circ} \\
145^{\circ} 13^{\circ} \\
145^{\circ} 13^{\circ} \\
145^{\circ} 13^{\prime}\end{array}$ & $\begin{array}{l}38^{\circ} \\
56^{\prime \prime} \\
31^{\prime \prime} \\
11^{\circ} \\
15^{\prime \prime} \\
26^{\circ}\end{array}$ & $\begin{array}{l}1745.0 \\
1766.1 \\
1764.0 \\
1778.0 \\
1734.8 \\
1.839 .0\end{array}$ & $\begin{array}{l}-28.72 \\
-29.48 \\
-28.82 \\
-27.61 \\
-31.22 \\
-27.66\end{array}$ & $\begin{array}{l}-88.22 \\
-89.69 \\
-88.96 \\
-88.23 \\
-90.00 \\
-90.36\end{array}$ & $\begin{array}{l}-88.22 \\
-89.69 \\
-88.96 \\
-88.23 \\
-90.00 \\
-90.36\end{array}$ & $\begin{array}{l}-82.15 \\
-83.57 \\
-82.83 \\
-82.06 \\
-83.95 \\
-83.94\end{array}$ \\
\hline $\begin{array}{l}\text { GM11 } \\
\text { GM12 } \\
\text { GM13 } \\
\text { GM15 } \\
\text { GM17 } \\
\text { GM19 } \\
\text { GM21 } \\
\text { GM67 \& GM23 }\end{array}$ & $\begin{array}{l}62^{\circ} 05^{\prime} \\
62^{\circ} 06^{\prime} \\
62^{\circ} 05^{\prime} \\
62^{\circ} 05^{\prime} \\
62^{\circ} 06^{\prime} \\
62^{\circ} 07^{\prime} \\
62^{\circ} 07^{\prime}\end{array}$ & $\begin{array}{l}32^{\circ} \\
17^{\circ} \\
46^{\circ} \\
40^{\prime \prime} \\
51^{\circ} \\
47^{\circ} \\
43^{\circ}\end{array}$ & $\begin{array}{l}145^{\circ} 08^{\prime} \\
145^{\circ} 06^{\circ} \\
145^{\circ} 03^{\circ} \\
145^{\circ} 05^{\prime} \\
145^{\circ} 07^{\circ} \\
145^{\circ} 10^{\prime} \\
145^{\circ} 14^{\prime}\end{array}$ & $\begin{array}{l}45^{\prime \prime} \\
36^{\circ} \\
37^{\circ} \\
27^{\prime \prime} \\
13^{\prime \prime} \\
38^{\circ} \\
45^{\prime \prime}\end{array}$ & $\begin{array}{l}2228.0 \\
2389.2 \\
2507.0 \\
2421.4 \\
2359.0 \\
2137.7 \\
1805.1\end{array}$ & $\begin{array}{r}-14.16 \\
-11.14 \\
-10.06 \\
-11.43 \\
-11.44 \\
-11.21 \\
-16.54\end{array}$ & $\begin{array}{l}-90.12 \\
-92.60 \\
-95.54 \\
-93.99 \\
-91.65 \\
-84.10 \\
-78.09\end{array}$ & $\begin{array}{l}-90.12 \\
-92.60 \\
-95.54 \\
-93.99 \\
-91.65 \\
-84.10 \\
-78.09\end{array}$ & $\begin{array}{l}-82.29 \\
-84.32 \\
-86.85 \\
-85.60 \\
-83.13 \\
-76.68 \\
-71.82\end{array}$ \\
\hline $\begin{array}{l}\text { Shrub } \\
\text { GM25 } \\
\text { GM27 } \\
\text { GM29 } \\
\text { GM31 } \\
634 \\
635 \\
G 36 \\
G 36 \\
637 \\
638 \\
639 \\
\text { G40 } \\
641 \\
642 \\
643\end{array}$ & 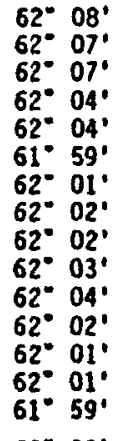 & $\begin{array}{l}59^{\circ} \\
07^{\circ} \\
28^{\prime \prime} \\
16^{\prime \prime} \\
58^{\circ} \\
26^{\prime \prime} \\
16^{\prime \prime} \\
10^{\prime \prime} \\
38^{\prime \prime} \\
14^{\prime \prime} \\
04^{\prime \prime} \\
32^{\prime \prime} \\
54^{\prime \prime} \\
27^{\prime \prime} \\
34^{\prime \prime}\end{array}$ & $\begin{array}{l}145^{\circ} 011^{\prime} \\
145^{\circ} 03^{\prime} \\
145^{\circ} 00^{\prime} \\
145^{\circ} 07^{\prime} \\
145^{\circ} 07^{\prime} \\
145^{\circ} 16^{\prime} \\
145^{\circ} 16^{\prime} \\
145^{\circ} 15^{\prime} \\
145^{\circ} 16^{\prime} \\
145^{\circ} 16^{\prime} \\
145^{\circ} 17^{\prime} \\
145^{\circ} 14^{\prime} \\
145^{\circ} 14^{\circ} \\
145^{\circ} 14^{\prime} \\
145^{\circ} 10^{\prime}\end{array}$ & $\begin{array}{l}08^{\circ} \\
43^{\circ} \\
23^{\circ} \\
52^{\circ} \\
25^{\circ} \\
23^{\circ} \\
09^{\circ} \\
37^{\circ} \\
09^{\circ \prime} \\
05^{\circ} \\
47^{\circ} \\
32^{\circ} \\
05^{\circ} \\
05^{\circ} \\
20^{\circ}\end{array}$ & $\begin{array}{l}2943.0 \\
2511.3 \\
2552.0 \\
2: 229.0 \\
2: 245.9 \\
1144.3 \\
1542.8 \\
1 ! 594.5 \\
1604.8 \\
1641.8 \\
1571.8 \\
1675.9 \\
1622.0 \\
1605.2 \\
1110.1\end{array}$ & $\begin{array}{r}6.25 \\
-7.03 \\
-4.04 \\
-16.25 \\
-16.54 \\
-30.65 \\
-29.81 \\
-32.43 \\
-32.76 \\
-32.68 \\
-33.80 \\
-31.40 \\
-33.03 \\
-33.00 \\
-26.97\end{array}$ & $\begin{array}{l}-94.09 \\
-92.65 \\
-94.21 \\
-92.04 \\
-92.87 \\
-79.89 \\
-82.42 \\
-86.79 \\
-87.48 \\
-88.65 \\
-87.39 \\
-88.54 \\
-88.33 \\
-87.73 \\
-85.28\end{array}$ & $\begin{array}{l}-92.09 \\
-92.65 \\
-94.21 \\
-92.04 \\
-92.87 \\
-79.62 \\
-82.42 \\
-96.79 \\
-87.48 \\
-88.65 \\
-87.39 \\
-88.54 \\
-88.33 \\
-87.73 \\
-85.28\end{array}$ & $\begin{array}{l}-82.47 \\
-83.96 \\
-84.87 \\
-84.16 \\
-84.96 \\
-74.67 \\
-77.06 \\
-81.26 \\
-81.91 \\
-82.96 \\
-81.97 \\
-82.73 \\
-82.73 \\
-82.19 \\
-79.34\end{array}$ \\
\hline $\begin{array}{l}G 44 \\
G 45 \\
646 \\
G 47 \\
G 48 \\
649 \\
G 50 \\
G 51 . \\
652 . \\
G M 77, G M 73 \\
G M, 63, G 53\end{array}$ & $\begin{array}{l}62^{\circ} 00^{\prime} \\
62^{\circ} 01^{\prime} \\
62^{\circ} 02^{\circ} \\
62^{\circ} 03^{\prime} \\
62^{\circ} 03^{\prime} \\
62^{\circ} 02^{\circ} \\
62^{\circ} 00^{\circ} \\
61^{\circ} 59^{\circ} \\
62^{\circ} 00^{\prime}\end{array}$ & $\begin{array}{l}56^{\circ} \\
43^{\prime \prime} \\
26^{\prime \prime} \\
27^{\prime \prime} \\
47^{\prime \prime} \\
55^{\prime \prime} \\
34^{\prime \prime} \\
38^{\circ \prime} \\
23^{\prime \prime}\end{array}$ & $\begin{array}{l}145^{\circ} 11^{\prime} \\
145^{\circ} 11^{\prime} \\
145^{\circ} 11^{\circ} \\
145^{\circ} 11^{\prime} \\
145^{\circ} 08^{\prime} \\
145^{\circ} 09^{\prime} \\
145^{\circ} 08^{\prime} \\
145^{\circ} 05^{\prime} \\
145^{\circ} 03^{\prime}\end{array}$ & $\begin{array}{l}35^{\prime \prime} \\
38^{\circ} \\
02^{\circ} \\
28^{\prime \prime} \\
29^{\circ} \\
02^{\prime \prime} \\
31^{\prime \prime} \\
59^{\prime \prime} \\
31^{\circ}\end{array}$ & $\begin{array}{l}1674.6 \\
1689.3 \\
1765.2 \\
1876.3 \\
2155.5 \\
2023.1 \\
1896.8 \\
20.57 .7 \\
22.30 .5\end{array}$ & $\begin{array}{l}-30.46 \\
-30.00 \\
-29.25 \\
-26.28 \\
-18.48 \\
-22.15 \\
-25.12 \\
-19.93 \\
-18.14\end{array}$ & $\begin{array}{l}-87.56 \\
-87.60 \\
-89.47 \\
-90.25 \\
-91.97 \\
-91.13 \\
-89.80 \\
-90.43 \\
-93.98\end{array}$ & $\begin{array}{l}-87.56 \\
-87.60 \\
-89.32 \\
-90.25 \\
-91.85 \\
-90.98 \\
-89.68 \\
-90.19 \\
-93.98\end{array}$ & $\begin{array}{l}-81.74 \\
-81.73 \\
-83.25 \\
-83.73 \\
-85.39 \\
-84.02 \\
-83.15 \\
-83.08 \\
-86.28\end{array}$ \\
\hline $\begin{array}{l}\text { Upper KIawasi } \\
\text { G54 } \\
\text { G55 } \\
\text { G56 } \\
\text { G57 } \\
\text { G58 } \\
\text { GM59 } \\
\text { GM60 } \\
\text { GM61 } \\
\text { GM62 } \\
\text { GM64 } \\
6 M 65 \\
\text { GM66 } \\
\text { GM68 } \\
\text { GM69 } \\
\text { GM70 } \\
\text { GM71 } \\
\text { GM72 } \\
674 \\
675 \\
\text { G76 } \\
\text { G78 } \\
\text { G79 } \\
680 \\
G M B 1\end{array}$ & 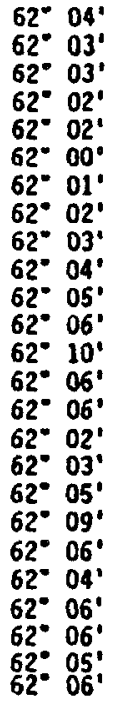 & 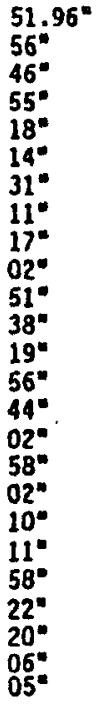 & $\begin{array}{l}145^{\circ} 00^{\circ} \\
145^{\circ} 00^{\circ} \\
144^{\circ} 57^{\prime} \\
144^{\circ} 59^{\circ} \\
145^{\circ} 01^{\circ} \\
144^{\circ} 58^{\circ} \\
145^{\circ} 06^{\circ} \\
145^{\circ} 03^{\circ} \\
145^{\circ} 05^{\prime} \\
145^{\circ} 03^{\circ} \\
144^{\circ} 58^{\circ} \\
145^{\circ} 00^{\prime} \\
145^{\circ} 01^{\circ} \\
145^{\circ} 15^{\circ} \\
145^{\circ} 23^{\prime} \\
145^{\circ} 20^{\circ} \\
145^{\circ} 21^{\prime} \\
145^{\circ} 19^{\prime} \\
145^{\circ} 04^{\circ} \\
145^{\circ} 08^{\prime} \\
145^{\circ} 09^{\circ} \\
145^{\circ} 12^{\circ} \\
145^{\circ} 18^{\prime} \\
145^{\circ} 16^{\circ} \\
145^{\circ} 06^{\prime}\end{array}$ & $\begin{array}{l}21.03^{\prime \prime} \\
25^{\circ} \\
43^{\prime \prime} \\
37^{\circ} \\
19^{\circ} \\
10^{\circ} \\
30^{\circ} \\
28^{\prime \prime} \\
26^{\prime \prime} \\
32^{\circ} \\
17^{\prime \prime} \\
42^{\circ} \\
20^{\prime \prime} \\
13^{\prime \prime} \\
10^{\circ} \\
31^{\prime \prime} \\
56^{\circ} \\
35^{\circ} \\
16^{\prime \prime} \\
32^{\circ} \\
33^{\circ} \\
43^{\prime \prime} \\
20^{\circ} \\
02^{\circ} \\
43^{\circ}\end{array}$ & 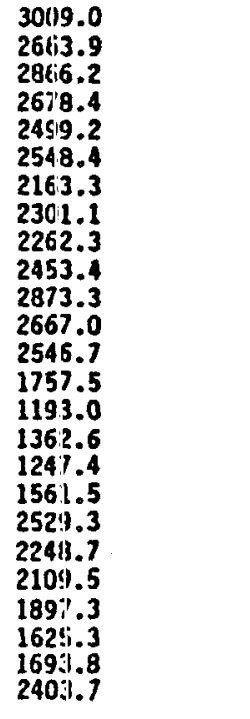 & $\begin{array}{r}3.75 \\
-5.18 \\
.42 \\
-6.06 \\
-10.19 \\
-12.10 \\
-17.80 \\
-15.93 \\
-15.54 \\
-10.64 \\
-40 \\
-4.43 \\
-3.43 \\
-22.22 \\
-38.91 \\
-38.16 \\
-43.18 \\
-32.82 \\
-2.93 \\
-13.52 \\
-20.10 \\
-20.80 \\
-25.24 \\
-29.86 \\
-9.27\end{array}$ & $\begin{array}{l}-98.85 \\
-96.01 \\
-97.31 \\
-97.38 \\
-95.40 \\
-98.99 \\
-91.56 \\
-94.38 \\
-92.68 \\
-94.29 \\
-97.27 \\
-95.36 \\
-90.26 \\
-82.14 \\
-79.58 \\
-84.62 \\
-85.71 \\
-86.06 \\
-89.17 \\
-90.19 \\
-92.03 \\
-85.49 \\
-80.65 \\
-87.61 \\
-91.22\end{array}$ & $\begin{array}{l}-97.29 \\
-96.01 \\
-97.16 \\
-97.28 \\
-95.40 \\
-98.99 \\
-91.56 \\
-94.38 \\
-92.68 \\
-94.29 \\
-97.13 \\
-95.36 \\
-90.26 \\
-82.14 \\
-79.47 \\
-84.22 \\
-85.60 \\
-85.95 \\
-89.03 \\
-90.19 \\
-92.03 \\
-85.39 \\
-80.65 \\
-87.61 \\
-91.22\end{array}$ & $\begin{array}{l}-87.09 \\
-86.74 \\
-87.29 \\
-88.05 \\
-86.78 \\
-90.14 \\
-84.07 \\
-86.44 \\
-84.87 \\
-85.82 \\
-87.23 \\
-86.16 \\
-81.47 \\
-76.04 \\
-75.36 \\
-79.56 \\
-81.31 \\
-80.57 \\
-80.31 \\
-82.38 \\
-84.68 \\
-78.85 \\
-75.04 \\
-81.55 \\
-82.89\end{array}$ \\
\hline
\end{tabular}


APPENDIX A (CONT.)

\begin{tabular}{|c|c|c|c|c|c|c|c|c|}
\hline Station & Latitude & & Longltude & Elevation (ft.) & $F M$ & $\begin{array}{l}0=2.67 \\
S B A\end{array}$ & $\begin{array}{c}0=2.67 \\
C B A \\
\end{array}$ & $\begin{array}{c}0=2.4 \\
C B A \\
\end{array}$ \\
\hline $\begin{array}{l}\text { GM82 } \\
\text { GMB3 } \\
\text { GM84 } \\
\text { GM85 } \\
\text { GM86 } \\
\text { GM87 } \\
\text { GA1 }(-G M 27) \\
\text { GA2 }(-G M 66) \\
\text { GA3 }(-G 74) \\
\text { GA4 } \\
\text { GA5 }(-G M 12) \\
\text { GA6 } \\
\text { GA7 } \\
\text { GAB }(-G 48) \\
\text { GA9 } \\
\text { GA10 } \\
\text { GA11 }(-G 80) \\
\text { GA12 (-G78) } \\
\text { GA13 }(-G 57) \\
\text { GA14 } \\
\text { GA15 } \\
\text { GA16 }(-G 45) \\
\text { GA17 } \\
\text { GA18 }(-G 34) \\
\text { GA19 } \\
\text { GA20 } \\
\text { GA21 } \\
\text { GA22 }(-G M 71) \\
\text { GA23 } \\
\text { (BM O 27) }\end{array}$ & 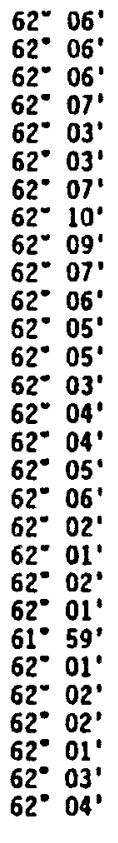 & $\begin{array}{l}40^{\prime \prime} \\
25^{\prime \prime} \\
31^{\prime \prime} \\
45^{\prime \prime} \\
53^{\prime \prime} \\
52^{\prime \prime} \\
30^{\prime \prime} \\
19^{\prime \prime} \\
10^{\prime \prime} \\
13^{\prime \prime} \\
15^{\prime \prime} \\
19^{\prime \prime} \\
35^{\prime \prime} \\
48^{\prime \prime} \\
17^{\prime \prime} \\
44^{\prime \prime} \\
06^{\prime \prime} \\
20^{\prime \prime} \\
18^{\prime \prime} \\
28^{\prime \prime} \\
47^{\prime \prime} \\
43^{\prime \prime} \\
26^{\prime \prime} \\
16^{\prime \prime} \\
05^{\prime \prime} \\
31^{\prime \prime} \\
54^{\prime \prime} \\
55^{\prime \prime} \\
29^{\prime \prime}\end{array}$ & 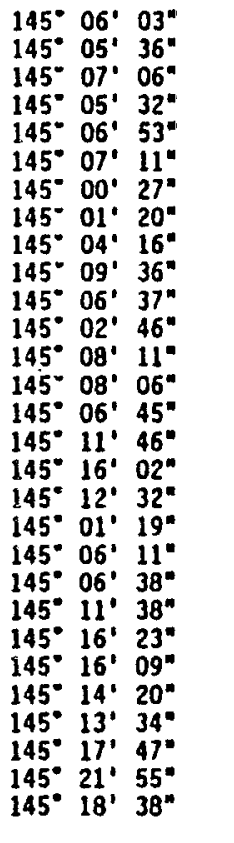 & $\begin{array}{l}2444.0 \\
2438.1 \\
2386.4 \\
2444.9 \\
2275.9 \\
2239.0 \\
2648.3 \\
2560.4 \\
2525.7 \\
2158.7 \\
2393.2 \\
2536.6 \\
2228.1 \\
2162.1 \\
2243.6 \\
1880.1 \\
1693.8 \\
1893.3 \\
2494.6 \\
2132.0 \\
2192.6 \\
1692.4 \\
1426.5 \\
1536.7 \\
1653.7 \\
1675.5 \\
1515.0 \\
1259.2 \\
1580.1\end{array}$ & $\begin{array}{l}-7.92 \\
-9.28 \\
-10.24 \\
-5.02 \\
-12.98 \\
-14.07 \\
-3.92 \\
-2.14 \\
-3.19 \\
-13.10 \\
-10.98 \\
-8.73 \\
-14.84 \\
-18.17 \\
-16.05 \\
-25.75 \\
-29.76 \\
-21.76 \\
-10.07 \\
-21.04 \\
-18.15 \\
-30.74 \\
-32.01 \\
-30.14 \\
-30.63 \\
-32.19 \\
-31.98 \\
-42.28 \\
-32.41\end{array}$ & $\begin{array}{l}-91.25 \\
-92.41 \\
-91.61 \\
-88.38 \\
-90.58 \\
-90.41 \\
-94.22 \\
-89.44 \\
-89.30 \\
-86.71 \\
-92.58 \\
-95.22 \\
-90.81 \\
-91.88 \\
-92.55 \\
-89.85 \\
-87.51 \\
-86.31 \\
-95.12 \\
-93.73 \\
-92.91 \\
-88.44 \\
-80.64 \\
-82.54 \\
-87.01 \\
-89.32 \\
-83.63 \\
-85.21 \\
-86.28\end{array}$ & $\begin{array}{l}-91.25 \\
-92.41 \\
-91.61 \\
-88.38 \\
-90.58 \\
-90.41 \\
-94.22 \\
-89.44 \\
-89.16 \\
-86.71 \\
-92.58 \\
-95.22 \\
-90.81 \\
-91.76 \\
-92.55 \\
-89.75 \\
-87.51 \\
-86.21 \\
-95.12 \\
-93.73 \\
-92.85 \\
-88.44 \\
-80.40 \\
-82.54 \\
-87.01 \\
-89.32 \\
-83.63 \\
-85.10 \\
-86.18\end{array}$ & $\begin{array}{l}-82.78 \\
-83.96 \\
-83.34 \\
-79.92 \\
-82.73 \\
-82.69 \\
-85.05 \\
-80.61 \\
-80.46 \\
-79.22 \\
-84.28 \\
-86.43 \\
-83.07 \\
-84.31 \\
-84.77 \\
-83.27 \\
-81.65 \\
-79.69 \\
-86.51 \\
-86.31 \\
-85.30 \\
-82.56 \\
-75.50 \\
-77.20 \\
-81.30 \\
-83.51 \\
-78.35 \\
-80.77 \\
-80.74\end{array}$ \\
\hline $\begin{array}{l}\text { GA24 FAA } \\
\text { GA25 } \\
\text { GA26 } \\
\text { GA27 } \\
\text { GA28 } \\
\text { S94 }\end{array}$ & $\begin{array}{l}62^{\circ} 09^{\prime} \\
62^{\circ} 07^{\prime} \\
62^{\circ} 07^{\prime} \\
62^{\circ} 07^{\circ} \\
62^{\circ} 05^{\prime} \\
61^{\circ} 57^{\prime}\end{array}$ & $\begin{array}{l}32^{\prime \prime} \\
56^{\prime \prime} \\
57^{\circ} \\
11^{\circ} \\
14^{\circ} \\
08^{\prime \prime}\end{array}$ & $\begin{array}{lll}145^{\circ} & 27^{\prime} & 23^{\prime \prime} \\
145^{\circ} & 24^{\prime} & 43^{\prime \prime} \\
145^{\circ} & 20^{\prime} & 19^{\prime \prime} \\
145^{\circ} & 23^{\prime} & 01^{\circ} \\
145^{\circ} & 22^{\prime} & 35^{\prime \prime} \\
145^{\circ} & 18^{\prime} & 23^{\circ}\end{array}$ & $\begin{array}{l}1572.3 \\
1208.9 \\
1523.8 \\
1230.8 \\
1313.7 \\
1032.0\end{array}$ & $\begin{array}{l}-18.06 \\
-31.52 \\
-24.50 \\
-35.92 \\
-40.23 \\
-39.98\end{array}$ & $\begin{array}{l}-71.66 \\
-72.74 \\
-76.46 \\
-77.89 \\
-85.02 \\
-74.16\end{array}$ & $\begin{array}{l}-71.66 \\
-72.61 \\
-76.46 \\
-77.78 \\
-84.91 \\
-74.16\end{array}$ & $\begin{array}{l}-66.24 \\
-68.45 \\
-71.20 \\
-73.54 \\
-80.39 \\
-70.53\end{array}$ \\
\hline $\begin{array}{l}\text { N90 } \\
\text { U60 } \\
226 \\
\text { Tazilina } \\
094 \\
\text { M60 } \\
\text { L60 } \\
\text { S26 } \\
\text { Glena }\end{array}$ & $\begin{array}{l}62^{\circ} 09^{\prime} \\
62^{\circ} 08^{\prime} \\
62^{\circ} 07^{\prime} \\
62^{\circ} 04^{\prime} \\
61^{\circ} 58^{\prime} \\
61^{\circ} 58^{\prime} \\
61^{\circ} 59^{\prime} \\
62^{\circ} 00^{\prime} \\
62^{\circ} 06^{\circ}\end{array}$ & $\begin{array}{l}35^{\prime \prime} \\
21^{\prime \prime} \\
17 " \\
49.20^{\circ} \\
23^{\prime \prime} \\
56^{\prime \prime} \\
52^{\prime \prime} \\
40^{\circ} \\
29^{\circ}\end{array}$ & 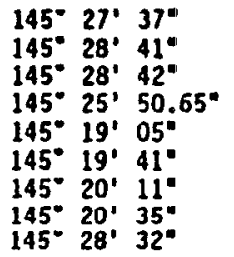 & $\begin{array}{l}1568.6 \\
1551.2 \\
1528.0 \\
1419.7 \\
1032.1 \\
1039 . \\
1137.0 \\
1207.2 \\
1512.0\end{array}$ & $\begin{array}{l}-17.71 \\
-21.12 \\
-25.55 \\
-37.32 \\
-41.92 \\
-42.95 \\
-41.57 \\
-40.11 \\
-29.24\end{array}$ & $\begin{array}{l}-71.19 \\
-74.01 \\
-77.65 \\
-85.73 \\
-77.11 \\
-78.39 \\
-80.34 \\
-81.27 \\
-80.79\end{array}$ & $\begin{array}{l}-71.19 \\
-74.01 \\
-77.65 \\
-84.86 \\
-77.11 \\
-78.38 \\
-80.34 \\
-81.05 \\
-80.79\end{array}$ & $\begin{array}{l}-65.78 \\
-68.66 \\
-72.38 \\
-80.05 \\
-73.50 \\
-74.80 \\
-76.42 \\
-76.91 \\
-75.57\end{array}$ \\
\hline
\end{tabular}


Aeromagnetic Surveys of Part of the Eastern Copper River Basin by

Eugene M. Wescott

\section{Introduction}

As part of the 1982 program to evaluate the geothermal potential of the Copper River Basin, the Alaska Division of Geological and Geophysical Surveys commissioned an aeromagnetic survey of parts of the Gulkana A-2 and A-3 quadrangles. ERTEC Airborne Systems, Inc. flew the survey and produced a total field, 1:63,360-scale contour map, reproduced here as Plate 8. The flight lines were flown at a nominal $500 \mathrm{ft}$ elevation above the terrain. The total field data were processed by subtracting the theoretical total field (the 1975 International Geomagnetic Reference Field) and then adding a constant 55,000 gammas. Flight paths were $1 / 2$ mile apart in the north-south direction, with east-west tie lines every three miles. The data were computer contoured at 10 gamma intervals. In contrast, the previous aeromagnetic data covering part of the area was flown at a constant altitude of $4000 \mathrm{ft}$ (Andreasen et al., 1958). To augment the aeromagnetic data our gravity survey crew took total field magnetometer readings on the ground at many of the stations, and a ground magnetic profile was run across lower Klawasi mud volcano.

\section{Discussion of Magnetic Results:}

Andreason et al. (1964), in their interpretation of the 1958 aeromagnetic map, observed a well defined semicircular pattern at the eastern edge of the map apparently centered on Mt. Drum, Figure 6-1. This feature resembles a pattern of lava flows coming off of Mt. Drum, and Andreasen et al., (1964) postulated that explanation. They 
suggested the depth to the lava flow unit as about $500 \mathrm{ft}$ at the western edge, a few miles west of the Copper River.

Contrary to this interpretation, the AMOCO Ahtna A-1 well, Figure 6-1, is located within the fan-like pattern, but there is no evidence in the log of a volcanic flow unit. This does not rule out the lava flow explanation because the fan would be composed of many individual flows which would not necessarily form a continuous layer, especially near the outer margin of the flows.

In the area of our detailed geochenical and geophysical surveys the magnetic trend of the Andreasen et al. (1958) map is east-west while the trend of the 1982 map (Plate 8) is generally north-south. We note that the earlier aeromagnetic survey was flown at a much higher altitude, which would eliminate smaller near-surface features and emphasize broader and/or deeper features. The 1982 survey at $500 \mathrm{ft}$ altitude above terrain was much more sensitive to smaller, near-surface features.

Plate 8 includes the area of Mt. Drum, with its conspicuous, large amplitude dipolar anomalies. Moving westward from Mt. Drum there is about a 4-mile-wide $\mathbb{N}$-S-trending zone of relatively smooth contours. Upper Klawasi mud volcano is near the middle of this zone, and Shrub is at the western edge. There is a prominent magnetic high ridge at the western edge which runs SSW from Shrub. West of this ridge the map appears very noisy with many short wavelength positive and negative anomalies of about 100 gammas amplitude. We made a semi-quantitative estimate of the average anomaly wavelength west and east of the ridge, and found they were similar: $1.20 \pm 0.45$ and $1.12 \pm 0.28$ miles respectively. The amplitude is less east of the ridge, and there are fewer anomalies. We also measured the statistical anomaly half width, which is useful 
to estimate the maximum depth to the body causing the anomaly. The average half width, $x_{1 / 2}$ was similar east and west of the ridge: $0.25 \pm 0.10$ miles. Standard half width depth rules are: sphere, $z=2 X_{1} / 2$; vertical cylinder, $z=1.3 X_{1 / 2}$; edge of a narrow dike, $z=X_{1 / 2}$; and a horizontal cylinder, $z=2 X_{1 / 2}$. Thus we conclude that the maximum depth to the noisy appearing anomalies is between 820 and $1640 \mathrm{ft}$ below the surface, but they may be at shallower depths or on the surface.

On Plate 8, there is a magnetic high of peak value 200 gammas, covering an area of about 4 square miles north and west of Shmab mud volcano. We note a close correlation of this feature with a glacial moraine mapped by Nichols and Yehle (1969). This moraine deposit probably contains gravel and boulders of high maknetic susceptibility, perhaps derived from glaciers heading at Mt. Drum. We speculate that in other areas of the map similar moraines may be buried under lake sediments and cause the noisy aeromagnetic pattern seen in Plate 8.

At the northwest corner of Plate 8 there is a broad magnetic high of about 400 gammas above average. This corresponds to the area of the gravity high shown on Plates 6 and 7 . Greenstone collected near Chitina which is thought to form the the basement has a high magnetic susceptibility (Table 6-1, Chapter 6), we believe these data indicate a topographic basement high. We ran a ground magnetometer traverse across lower Klawasi mud volcano, along self-potential survey line $\mathrm{C}-\mathrm{C}^{\prime}$; Plate 6 , from point $\mathrm{C}$ to the summit. Other spot readings were taken at gravity stations east of the summit. These data show a symmetrical negative anomaly of 180 gammas centered on the summit mud crater. No modelling was attempted of the gravity and magnetic anomalies here, but it seems clear that they are due to a cylinder of low density, low magnetic susceptibility mud pushed up from depth. 
In Chapter 6 we noted that the posj.tive gravity high coincident with helium anomaly \#5 appeared to correspond also with a magnetic low. The actual magnetic anomaly is better described as a narrow pinching of a magnetic ridge with magnetic lows on either side. If we make the assumption that the ridge was originally a smooth continuous feature which a separate, lower susceptibility body has perturbed, we can calculate the negative contours of the anomaly due to that second body. We ran a computer program to see if the proposed intrusive gravity body $A$, shown in Figure 6-2, Chapter 6 , could produce the magnetic anomaly if it had low magnetic susceptibility. The result was conclusive - it could not. The speculated magnetic anomaly is much sharper than the broad anomaly that model A would produce. The conclusion is that the cause of the necking of the ridge is much closer to the surface than the modelled intrusive body. Geothermal water is capable of causing magnetic minerals to be altered to non-magnetic alteration products. It is possible that this process is the cause of the magnetic pattern over the gravity anomaly. It is also possible that unrelated variations in a glacial morraine deposit could be the source of this magnetic pattern.

No additional magnetic work was carried out in 1984 . 


\section{REFERENCES}

Andreasen, G.E., W.J. Dempsen, J.R. Henderson, F.P. Gilbert, 1958, Aeromagnetic map of the Copper River Basin, Alaska, U.S. Geol. Survey, Geophys. Investigations Map GP-156.

Andreasen, G.E., Grantz, A., Zietly, I., Barnes, D.F., 1964, Geologic interpretation of magnetic and gravity data in the Copper River Basin, Alaska, U.S. Geol. Survey Prof. Paper 316-H, 135-153p.

Nichols, D.R., and Yehle, L.A., 1969, Engineering Geologic Map of the southeastern Copper River Basin, Alaska, U.S. Geol. Survey Miscellaneous Geologic Investigations Map I-524, scale 1:125,000. 
CHAPTER 8

Deep Electrical Resistivity Measurements

by

Eugene $M$. Wescott and Donald L. Turner

\section{Introduction}

Geothermal reservoirs can of ten be detected by measuring the electrical resistivity vs. depth from the surface. This is due to the fact that the resistivity of geothermal reservoirs is usually significantly lower than the resistivities of surrounding formations. The resistivity tends to be lower for two reasons: 1) resistivity of the water filling the pore spaces of the reservoir rock decreases with increasing temperature, and, 2) the hot water is able to dissolve more minerals than normal temperature ground water.

In our 1982 survey, electrical resistivity was not employed because lowresistivity, cold brines were known to occur at fairly shallow depths (see Chapter 1). The presence of these cold brines suggested that a geothermal reservoir might produce only a subtle resistivity contrast. Furthermore, the use of deep resistivity techniques is expensive and time consuming, and should only be used in areas previously found to be likely targets by cheaper, reconnaissance techniques.

When the 1984 follow-on exploration program was planned, the use of deep electrical surveying was deemed to be a useful technique. The results of the 1982 geophysical and geochemical surveys had located three areas of possible geothermal interest, limiting the locations where deep resistivity would be used. Since 1982, we had also acquired a resistivity transmitter capable of carrying 20 amperes of current in grounded dipoles, making deep measurements feasible. Also, Zonge et al (1980) demonstrated that the use of a technique called controlled source audio-magnetotellurics (CSAMT) combined with 
appropriate modelling techniques allowed detection of subtle resistivity anomalies within low resistivity backgrounds. Thus we decided to use CSAMT measurements combined with shallower Schlumberger vertical electric soundings (VES) to help evaluate the geothermal potential of helium anomaly He areas 1 , 3 , and 5 shown on Plate 1 and discussed in Chapter 2. Explanation of the CSAMT Method

Caigniard (1953) provided the basis for the magneto-telluric method of investigating resistivity vs. depth. Natural variations in the earth's magnetic field called micropulsations cause electric current to flow in the ground. By measuring the magnetic and perpendicular electric fields at the earth's surface at a wide range of frequencies, the apparent resistivity vs. Erequency can be calculated: $\rho_{a}=\frac{1}{5 f}\left|\frac{E_{x}}{H_{y}}\right|^{2}$ where $\rho_{a}$ is the apparent resistivity in $\Omega-m, f$ is the frequency in Hertz (cycles per second), $E_{x}$ is the electric field in $\mathrm{mV} / \mathrm{km}$ and $\mathrm{H}_{\mathrm{y}}$ is the magnetic field variation in gammas. The phase angle $\phi$ between $E_{x}$ and $H_{y}$ is also measured to provide a curve of $\phi$ vs. frequency. Caigniard (1953) showed that for an earth approximated by horizontal layers it was possible to interpret the apparent resistivity vs. frequency and phase angle vs. frequency curves in terms of true resistivity vs. depth. The depth of penetration of the magnetic and telluric waves depends upon frequency and resistivity, and is called the skin depth = $503 \sqrt{\rho / f}(m)$ or $1650 \sqrt{\rho / f}(f t)$ where $\rho$ is the earth's resistivity in $\Omega-m$ and $f$ is the frequency in $\mathrm{Hz}$. Table 8-1 shows the skin depth in $\mathrm{ft}$ vs. frequency and resistivity. 
Table 8-1

Skin Depth in Ft.

Resistivity in $\Omega-m$

\begin{tabular}{|c|c|c|c|c|c|c|c|c|c|}
\hline$f(\mathrm{~Hz})$ & 5 & 10 & 20 & 40 & 80 & 160 & 320 & 640 & 1280 \\
\hline 256 & 230 & 325 & 462 & 653 & 922 & 1305 & 1843 & 2668 & 3681 \\
\hline 128 & 325 & 462 & 653 & 922 & 1305 & 1843 & 2608 & 3687 & 5218 \\
\hline 64 & 462 & 653 & 922 & 1305 & 1843 & 2608 & 3687 & 5218 & 7377 \\
\hline 32 & 653 & 922 & 1305 & 1843 & 2608 & 3687 & 5218 & 7377 & 10434 \\
\hline 16 & 922 & 1305 & 1843 & 2608 & 3687 & 5218 & 7377 & 10434 & 14757 \\
\hline 8 & 1305 & 1843 & 2608 & 3687 & 5218 & 7377 & 10434 & 14757 & 20867 \\
\hline 4 & 1843 & 2608 & 3687 & 5218 & 7377 & 10434 & 14757 & 20867 & 29513 \\
\hline 2 & 2608 & 3687 & 5218 & 7377 & 10434 & 14757 & 20867 & 29513 & 41738 \\
\hline 1 & 3687 & 5218 & 7377 & 10434 & 14757 & 20867 & 29513 & 41738 & \\
\hline .5 & 5218 & 7377 & 10434 & 14757 & 20867 & 29513 & 41738 & & \\
\hline .25 & 7377 & 10434 & 14757 & 20867 & 29513 & 41738 & & & \\
\hline .125 & 10434 & 14757 & 20867 & 29513 & 41738 & & & & \\
\hline .0625 & 14757 & 20867 & 29513 & 41738 & & & & & \\
\hline
\end{tabular}


The frequencies used in Table $8-1$ are in the audio range and a little lower. Skin depths of at least $40,000 \mathrm{ft}$ are possible with natural audiomagnetotelluric soundings.

One drawback to the magnetotelluric method is that the natural signals of the earth's field are used, and long recording periods are of ten necessary to derive good apparent resistivity and phase curves because natural signals are unpredictable in strength and direction. In the controlled-source technique this problem is eliminated by using a grounded electric dipole as a signal source. Goldstein and Strangway 1975) showed that if the grounded dipole current transmitter was at a horizontal distance of greater than three skin depths from the $E$ and $H$ receiver, the conventional magnetotelluric interpretations could be applied.

In the CSAMT technique a single frequency is transmitted until sufficient cycles are received to measure $E_{x}$ and $H_{y}$ with satisfactory signal-to-noise ratios. The measurements are repeated at a range of frequencies. The receivers consist of a pair of non-polarizable electrodes at a dipole spacing "a" oriented parallel to the transmitter dipole to measure $E_{X}$, and usually an induction coll oriented perpendicular to the transmitter dipole to measure $H_{y}$. Some assets of CSAMT measurement:s are: 1) it is a good buried conductor detector; 2) it has excellent lateral resolution (limited only by the receiver "a" spacing), good depth of penetration and relatively fast survey speed; 3 ) apparent resistivity and phase are calculated in real time so that results can be seen in the field during the survey; and 4) frequency-domain-type filtering can be used for optimum noise rejection. Some disadvantages are: 1) effects of resistivity anomalies in the vicinj.ty of the transmitter may be seen; 2) effects of transition from the near fleld ( $D<3$ skin depths) to the far field (D > 3 skin depths) must be carefully removed from the analysis and; 3 ) 
modeling cannot always duplicate field results in intensity and sharpness, especially in the case of buried three-dimensional bodies.

Data from a CSAMT survey may be taken from a series of stations along a line, and simply plotted as apparent resistivity with horizontal distance and with frequency as inverse depth to produce a CSAMT pseudo-section. Although the depth scale is only approximate, it is often possible to interpret structures, pick out conducting zones, and delineate horizontal resistivity changes directly. Bostick (1977) presented an algorithm for Inverting the apparent resistivity and phase vs. frequency curves to approximate resistivity vs. depth. His algorithm written as a hand-held calculator program by Campbell (1981) can be used to convert the apparent resistivity-frequency pseudo-section to an approximate resistivity section. The Bostick-produced sections are only approximate, but of lier a better idea of the resistivity structure than the raw pseudo-section, and can be used as a starting point in more sophisticated data reduction programs.

\section{The 1984 CSAMT Survey}

We decided to use the CSAMT technique in profiles across the Tazlina helium anomaly area number 1 and acrosis helium anomaly areas 3 and 5 in the Klawasi area (Plate 1). The equipment used consisted of a 20 ampere Geotronics FT-20A transmitter powered by a Geotronics 30 KVA 400 cycle generator, and controlled by a Zonge Engineering crystal transmitter controller. The $E_{x}$ and $H_{x}$ signals were recorded by a Zonge Engineering GDP-12 receiver. The electric field $\left(E_{x}\right)$ was measured across grounded dipoles of either $328 \mathrm{ft}(100 \mathrm{~m})$ or $656 \mathrm{ft}(200 \mathrm{~m})$, while the $H_{x}$ signal was detected with a high-mu-cored coil of 80,000 turns. The GDP-12 receiver incorporates a computer which converts the analog signals to digital, stacks and averages these signals, and then computes the apparent resistivity and phase angle 
between $E$ and $H$. The possible frequencies transmitted are $256,128,64,16$, $8,4,2,1,1 / 2,1 / 4,1 / 8,1 / 16,1 / 32,1 / 64$ and $1 / 128 \mathrm{~Hz}$.

Before we decided on a transmitter-to-receiver distance we measured the resistivity vs. depth in two locations near the Tazlina area using the Schlumberger vertical electrical sounding technique (Keller and Frischknecht, 1966). Figures $8-1$ and $8-2$ show the apparent resistivity curves and the resistivity vs. depth curves computed with the automatic curve fitting program VES-32 (ABEM, 1983). VES 1 1 was measured at 1 mile west of the Richardson Highway on the pipeline access road just south of the Tazlina River. The high resistivity layers with a total thickriess of nearly $46 \mathrm{~m}$ or $150 \mathrm{ft}$ suggest permafrost of this thickness. The permafrost is underlain by sediments of $13.0 \Omega-m$ resistivity. VES $\$ 2$, Figure 8-2 was measured about $1000 \mathrm{ft}$ SE of the Alaska State Division of Natural Resources buildings on the bluff south of the Tazlina River. There are some probable permafrost layers about $50 \mathrm{ft}$ thick underlain by sediments with resistivity varying between 15 to $332 \Omega-m$.

Based upon the Schlumberger measurements we located a N-S, $9840 \mathrm{ft}(3000 \mathrm{~m})$ transmitter dipole in a permafrost area along a seismic line $6.2 \mathrm{miles}$ (10 $\mathrm{km}$ ) west of the CSAMT profile line passing near the former Copper Center school grounds. This distance of 3 skin depths implies that we could take measurements up to a skin depth of about $11,000 \mathrm{ft}$ without crossing the near field-far field transition. According to Table 8-1 this is well within the range of expected resistivities and our working frequencies. We ran a CSAMT measurement near the location of VES 1 , and seven soundings along a $N-S$ profile line across the Tazlina helium anomaly area. Figure 8-3 shows the location of the CSAMT profile stations.

Figure 8-4 shows the apparent resistivity/frequency pseudosection across the Tazlina anomaly. Each $\rho$ vs. f curve was well within the theoretical limits and 


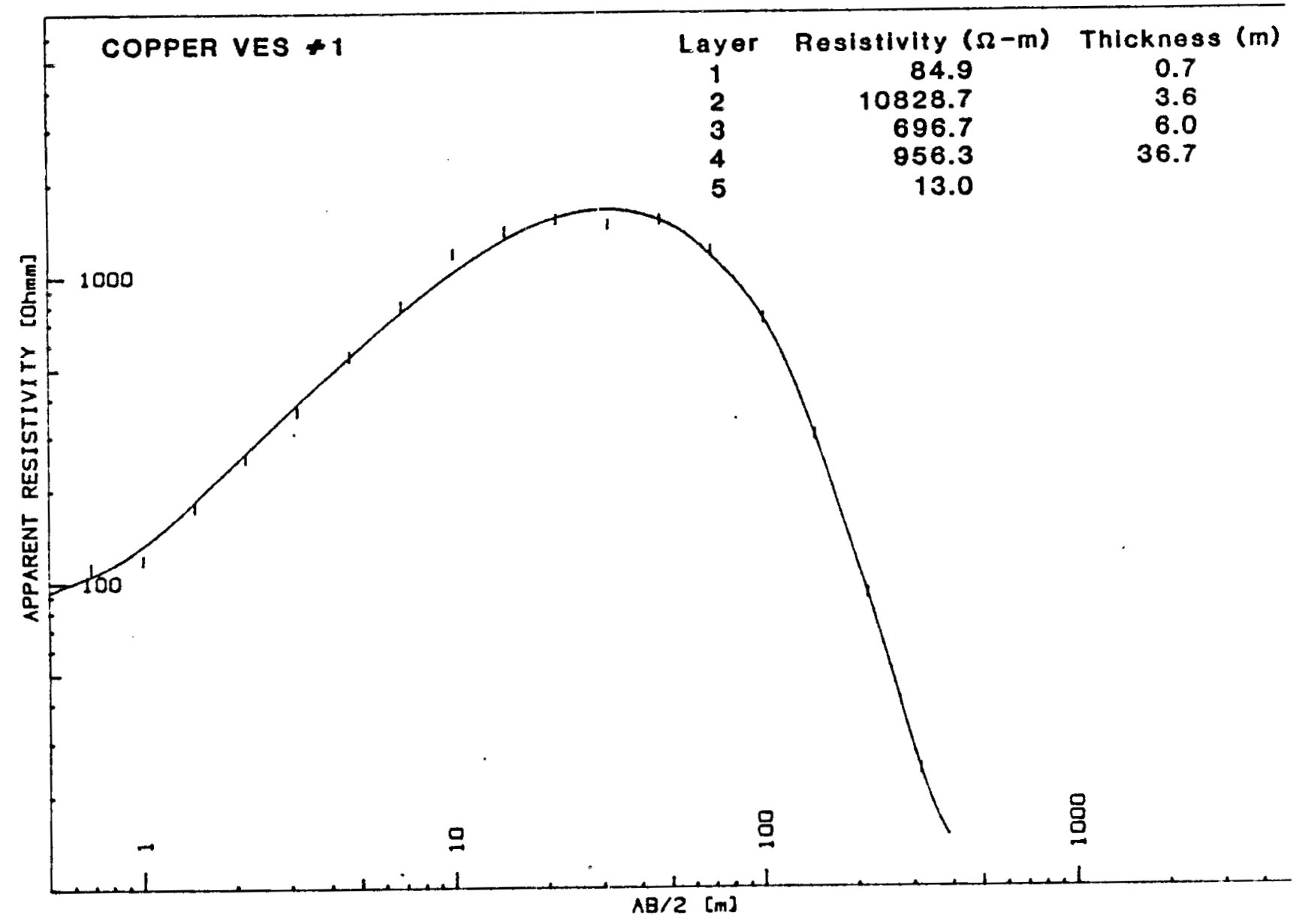

Figure 8-1. VES \#1 vertical electrical resistivity sounding datum points and five-layer theoretical curve fit for horlzontal layer assumption. The $13 \Omega-\mathrm{m}$ low resistivity layer starts at a depth of $150 \mathrm{ft}$. See Figure 8-3 for location of sounding. 


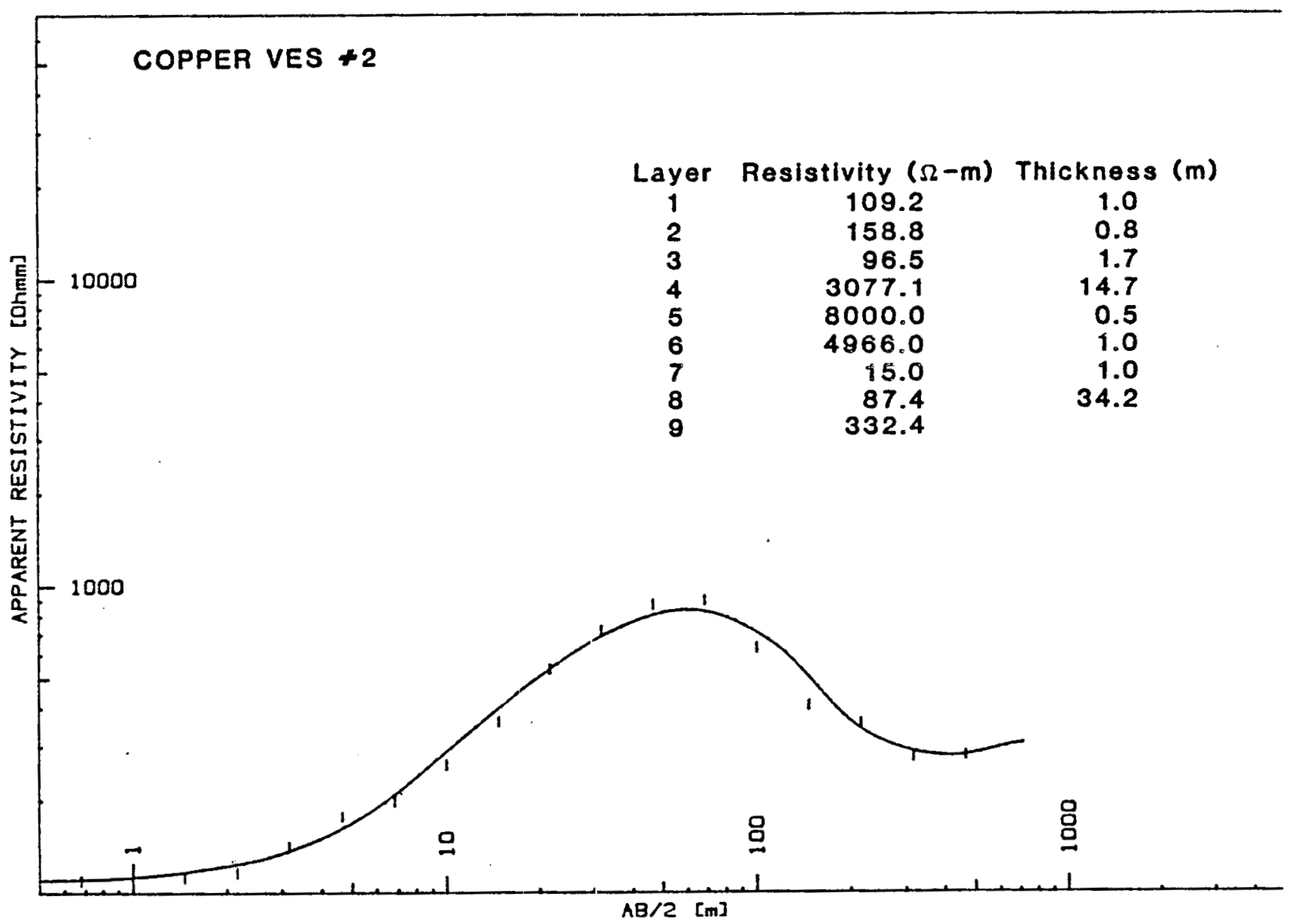

Figure 8-2. VES \#2 vertical electrical resistivity sounding datum points and nine-layer theoretical curve fit for horizontal layer assumption. There is no extensive low resistivity material at this site, but possibly 50 ft of high resistivity permafrost. See figure 8-3 for location of sounding. 
TAZLINA CSAMT SURVEY SURVEY

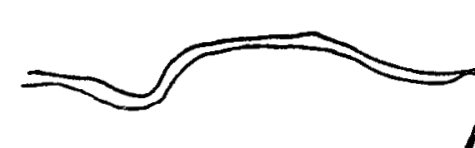

TX 1.86 MILES
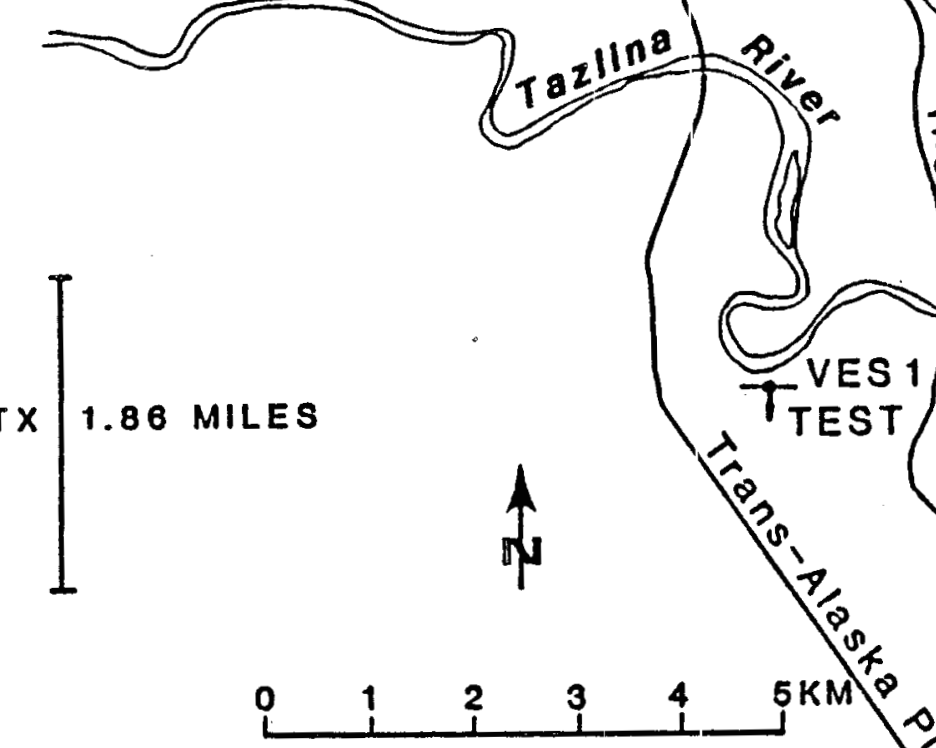

VES 1

River

- $\int \begin{gathered}\text { DE SAC } \\ \text { NO } \\ \text { TRESPASSING }\end{gathered}$
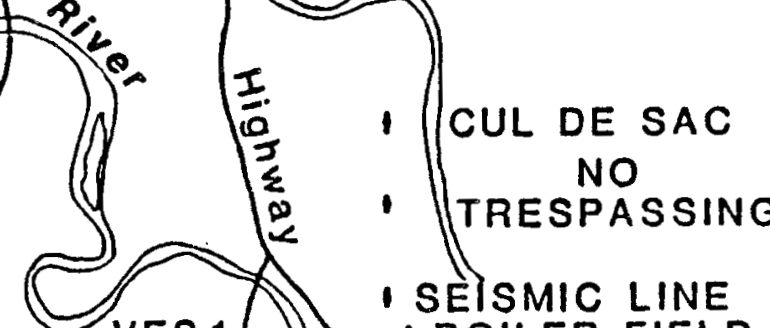

IBOILER FIELD

BALL PARK
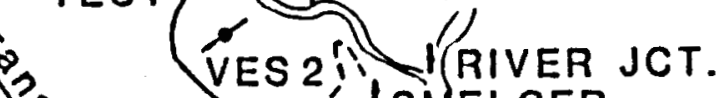

-' SMELCER

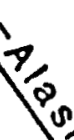



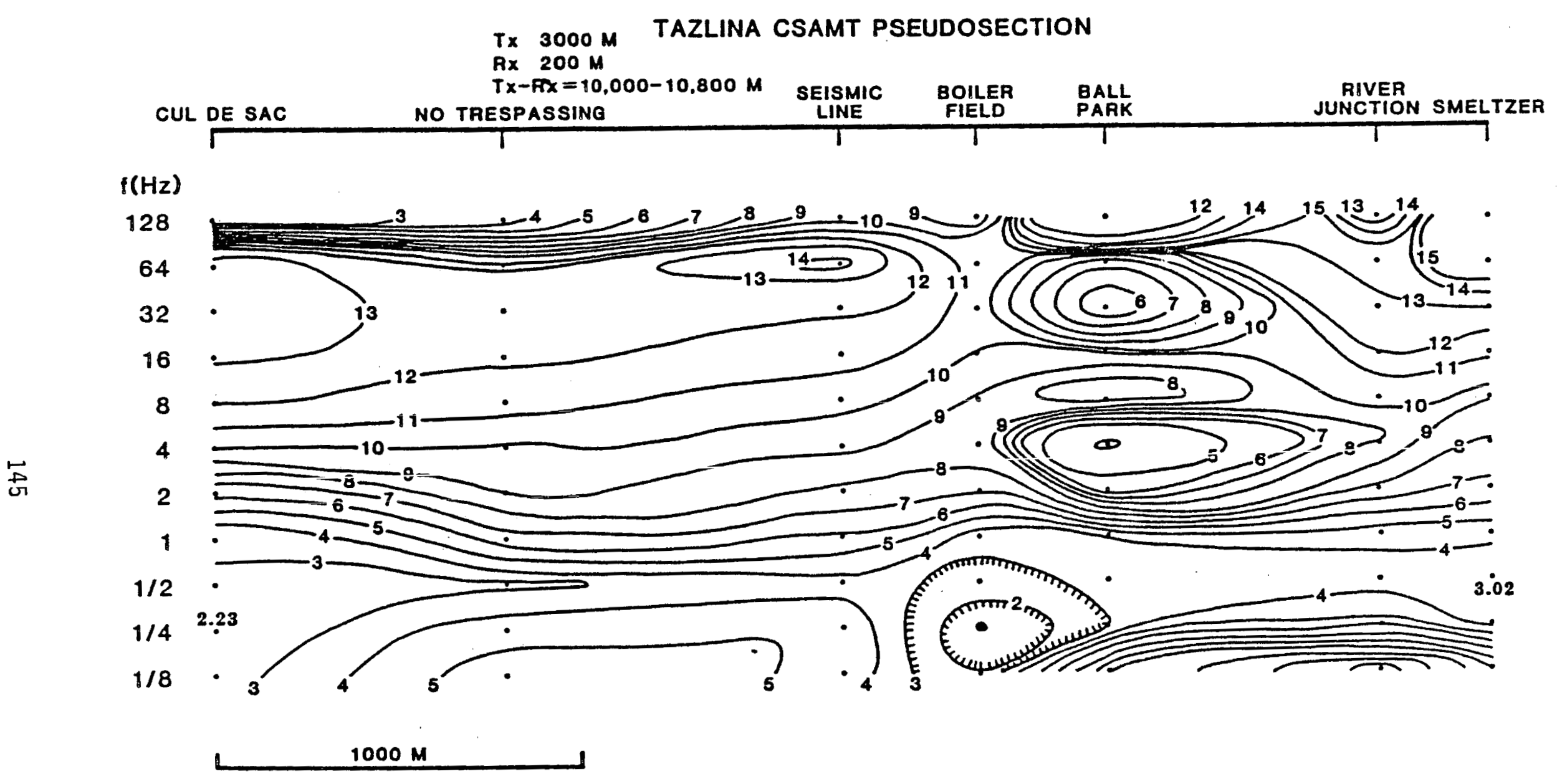

Figure 8-4. Controlled-source audio magnetotelluric pseudo-section across the Tazlina area. Apparent resistivity values in $\Omega$ - $m$ have been contoured vs. horizontal station position with frequency decreasing linearly by factors of 2 downwards. Note the low apparent resistivity values from 1 to $1 / 4 \mathrm{~Hz}$. 
could be inverted by means of the Bostick algorithm (Bostick, 1977; Campbel1, 1981). These data are shown as an interpreted section with no vertical exageration in Figure $8-5$.

For CSAMT measurements at helium anomalies 3 and 5 (Plate 1) we established a $6175 \mathrm{ft}(1883 \mathrm{~m})$ transmitting dipole straddling the lower Klawasi mud volcano, (Figure 8-6). Figure 8-6 also shows the location of eight CSAMT receiving sites more or less aligned N-S; crossing both He anomaly areas and the non-anomalous area between them. Distance from transmitter to receiver varied from 3.35 miles to 5.1 miles. We did not make any Schlumberger VES measurements in the Klawasi survey area, but did calculate the apparent galvanic resistivity based upon the transmitted current, the electrode geometries and the measured $\mathrm{E}$. All the values were low, ranging from 8.07 to $9.94 \Omega-\mathrm{m}$. Referring to Table $8-1$, and using $a$ resistivity value of $10 \Omega-\mathrm{m}$, we find that the skin depth for our operating frequencies would range from 325 to $21000 \mathrm{ft}$. Thus it is possible that the lower frequencies might cross the transition from near field to far field for the stations closest to the transmitter.

Figure 8-7 shows the pseudosection obtained in the Klawasi area. The resistivity gradients are steeper in some parts of each curve than allowed theoretically in the Bostick algorithm, so we did not produce an inverted section for this area. Discussion of Deep Electrical Resistivity Results

The Tazlina inverted section, Figure 8-5, shows a zone of low resistivity, with a minimum less than $1 \quad \Omega-\mathrm{m}$, varying in depth from 2460 to $2950 \mathrm{ft}$ (750-900 m). In the vicinity of the Ballpark end Boiler Field sites there is another low resistivity zone at depth of $1380 \mathrm{ft}(420 \mathrm{~m})$. The resistivity generally increases below the 2460-2950 ft zone. Above the low resistivity zone the background is fairly low, less than $10 \Omega-m$ generally, permafrost appears to be 


\section{TAZLINA INVERTED RESISTIVITY SECTION}

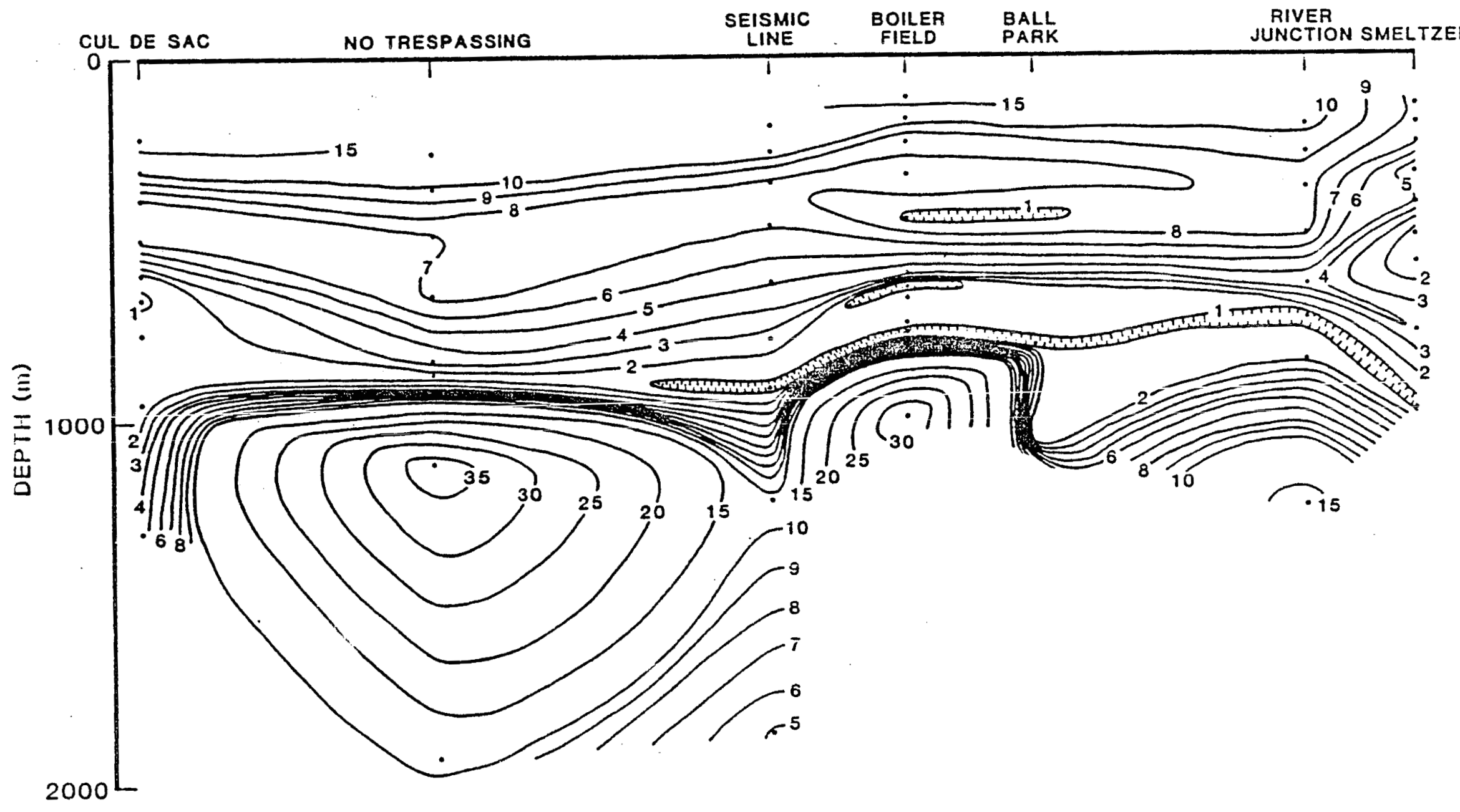

Figure 8-5. Section across the Tazlina area inverted from apparent resistivity and frequency to resistivity vs depth by the Bostick algorithm (Bostick, 1977; Campbe11, 1981). Note the low resistivity zone near $750 \mathrm{~m}$. 


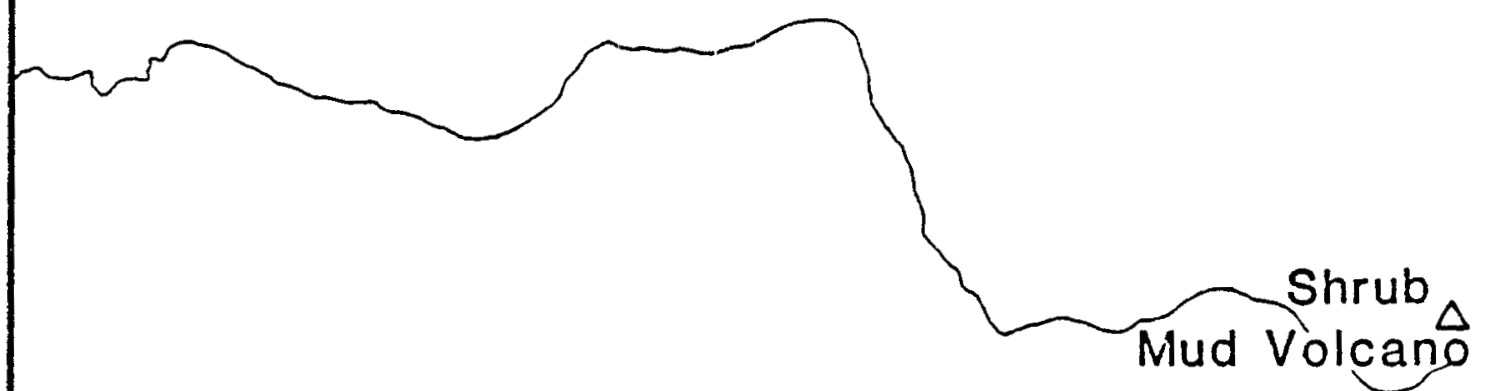

KLAWASI CSAMT SURVEY

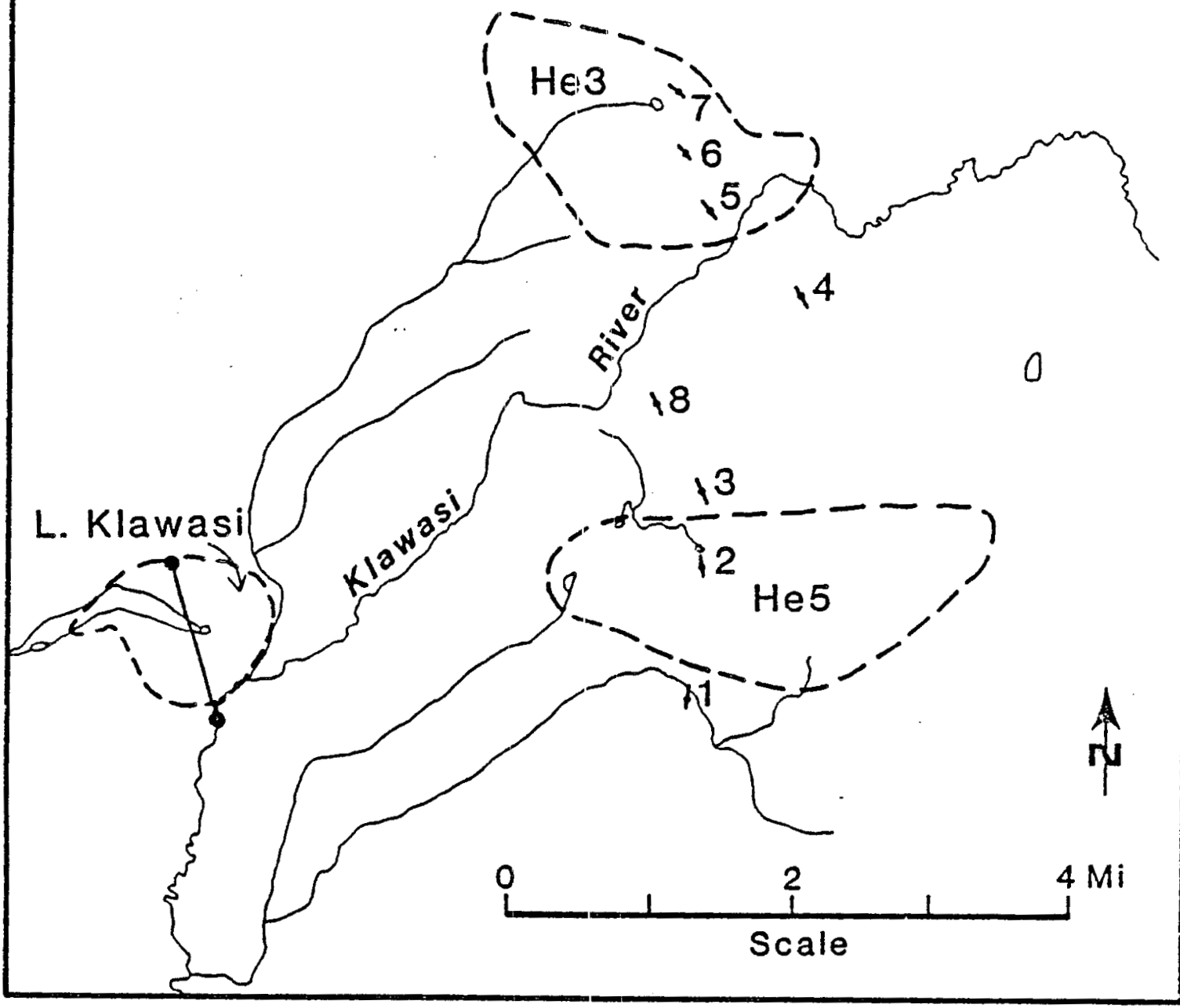

Figure 8-6. Locations of transmitting and receiving stations for the CSAIMT survey in the Klawasi mud volcano area. Dashed lines show outlines of lower Klawasi mud volcano and helium anomaly areas 3 and 5 from Plate 1. 


\section{KLAWASI CSAMT PSEUDOSECTION}

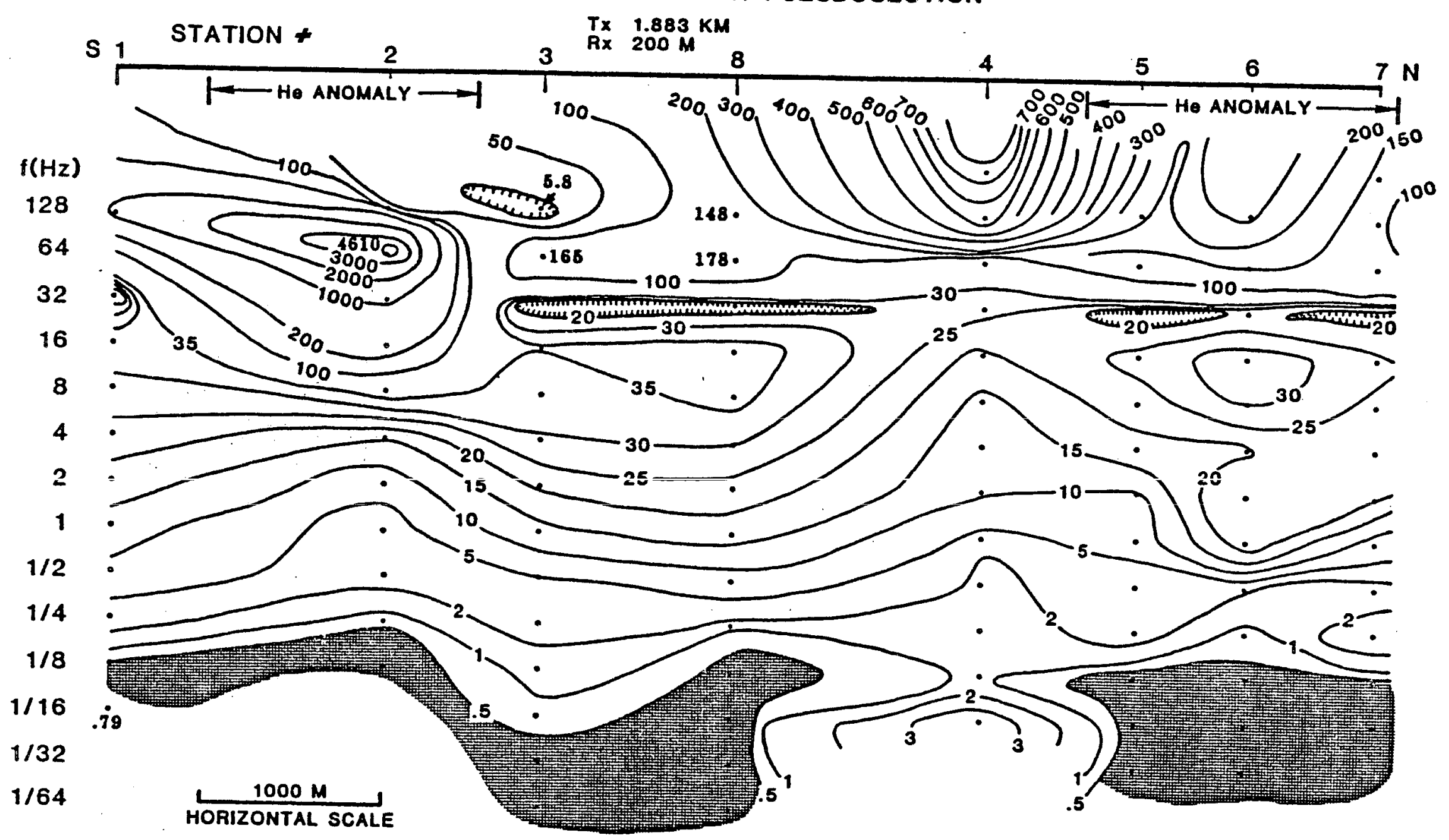

Figure 8-7. Apparent resistivity pseudo-section across the two major hellum anomaly areas in the vicinity of the Klawasi mud volcanoes.

High resistivity near the top suggests thick permafrost. Very low resistivity at the lowest frequencies is probably the saline marine clay which is erupted by the lower Klawasi mud volcano. 
absent, which is to be expected in the thaw bulb of the Copper River. This low resistivity background is not unreasonable for sediments saturated with a salt brine as discussed in Chapter 1 . The much lower resistivity of less than $1 \Omega-\mathrm{m}$ could possibly be interpreted as a geothermal layer. This would agree with the helium, mercury, and self-potential survey results, all of which show anomalies in the same area.

However, the low resistivity could also be due to a marine (saline) clay layer. After the field season we measured the resistivity of clay collected at the outlet of lower Klawasi mud volcano. We found a very low value of $0.175 \Omega-\mathrm{m}$. If the source of the clay coming up from depth at lower Klawas $i$ extends laterally under the Tazlina area, then the low resistivity zone may well this clay layer.

Figure 8-7 shows the pseudo-section for the Klawasi traverse. Because of the steeper-than-theoretical slopes, we could not make a conversion to a depth section. However, we can make some interpretations directly from the pseudosection. At the top, the highest frequencies show large apparent resistivity values. From observations in the holes augered for He and $\mathrm{Hg}$ sampling, the area is underlain by permafrost. The high apparent resistivity agrees with these observations, and suggests a thick section of permafrost. On Figure 8-7 note that near a frequency of $32 \mathrm{~Hz}$ there is a discontinuous layer of relatively low resistivity, less than $20 \Omega$ - m. This may be a layer. of concentrated brine forced downward as the sediments froze from above. Below that layer the resistivity increases somewhat, then drops to very low values near $1 / 4$ to $1 / 8 \mathrm{~Hz}$ and lower. By use of some partial Bostick interpretations, we infer that the low resistivity layer depth is about twice that at Tazlina (Figure 8-5) or $4900 \mathrm{ft}(1500 \mathrm{~m})$. The Klawasi area is at a higher elevation than the Tazlina profile, the difference is such that, if the low resistivity zone were horizontal and continuous between the 
two areas, it would be seen in the CSAMT profiles as observed. Since the lower Klawasi clay sample is of very low resistivity, it is very likely that the source of the clay is the low resistivity zone at about $4900 \mathrm{ft}$ depth. This suggests that the low resistivity zone is more likely to be a marine clay layer than a geothermal reservoir.

Klawasi clay sample is
of the clay is the lor
that the low resistiv
geothermal reservoir.




\section{References}

ABEM, Atlas Copco, 1983. Compact conputer program for automatic interpretation of resistivity soundings, $A B E M$ Instruction Manual, Atlas Copco ABEM AB, Box 20086, S-16120, Bromma, Sweden, 35 p.

Bostick, F. X., 1977. A simple almost exact method of MT analysis, in Ward, S. H., ed., Workshop on Electrical Methods in Geothermal Exploration: Univ. of Utah, Salt Lake City, UT, 841.12, p. 175-183.

Caigniard, L., 1953. Basic theory of: the magneto-telluric method of geophysical prospecting, Geophysics 18(3), p. 605-635.

Campbel1, D. L., 1981. MT inversion (Bostick's Algorithm) calculator program EM-8. In: Manual of Geophysical Hand-Calculator Programs, Society of Exploration Geophysicists, HP Volume, p. 1-8.

Goldstein, M. A. and D. W. Strangway, 1975. Audio-frequency magnetotellurics with a grounded electric dipole source, Geophysics Vol. 40 (4), p. 699-683.

Keller, G. V. and F. C. Frischknecht, 1966. Electrical methods in geophysical prospecting, Pergamon Press, New York, NY, p. 95-96.

Zonge, K. L., D. F. Emer and A. G. Ostrander, 1980. Controlled source audiof requency magnetotelluric measurements, Technical Papers of the 50 th S.E.G. Convention, Vol. V, p. 2491-2521. 
CHAPTER 9

SUMMARY AND CONCLUSIONS

by

Eugene M. Wescott and Donald L. Turner

In two field seasons (1982 and 1984) we have carried out reconnaissance and site specific geochemical and geophysical investigations to determine if geothermal resources are likely to be found in the Eastern Copper River Basin. The geologic setting of the area we investigated is one of thick glacial lake sediments and moraines laid down on the flanks of Mt. Drum, a volcano active as late as 200,000 years ago which may have retained significant amounts of heat at high levels. Further to the east an active volcano, Mt Wrangell, is an obvious source of volcanic heat today.

The basin itself has no definite surface expressions of a geothermal resource such as hot springs, fumaroles, hot water wells etc., so the geochemical and geophysical survey data, together with the known geologic background, are the clues we must consider. In an area of interest we can look at the results of each survey method and ask: Do they indicate yes geothermal, no - not geothermal or neutral - maybe. If all the results are positive, we would say there is a good chance that a drilling program might discover a resource. If all the methods are negative, it is unlikely that a resource exists. If the sum of the indicators is indeterminant, a geothermal resource is possible but may not be very likely, and the cost of further exploration may not be justified.

Given the state of knowledge in 1982 , it was reasonable to say the eastern Copper River Basin area might: have accessible geothermal resources underneath the lake sediments. The raud volcanoes were an obvious starting point. The Tolsona group were ruled out as having a geothermal driving force 
by their gas and water chemistry. An overpressured zone discovered in the Pan American Moose creek 非 well appears to be the source for this group of mud volcanoes.

The area near the Klawasi group of mud volcanoes and mineral springs, however, did seem to offer a possible geothermal exploration target. The mud volcano water geothermometry was ambiguous, suggesting either a cold source, or possibly a temperature above $150^{\circ} \mathrm{C}$. The $\mathrm{CO}_{2}$ gas emanating from the mud volcanoes was also suggested to have a source from thermal, or possibly chemical, decomposition of limestones or carbonate cemented sediments (Motyka, personal communication, 1982).

Our 1982 investigations in the vicinity of the Klawasi mud volcanoes and along the Richardson Highway road syistem produced three main areas of possible geothermal interest, as shown on Plate 1. The anomaly \#1 near the confluence of the Copper and Tazlina Rivers was only a helium soil gas anomaly, as it was discovered after the geophysical phase of the work had been completed. The other two helium anomalies ( 3 and 5, Plate 1), were also associated with gravity, magnetic and some self-potelntial anomalies. Based on these results, more detailed, follow-on geophysical and geochemical surveys were conducted in 1984.

Although the 1984 helium analyses were much improved by newly-developed corrections for soil environment conditions, the results agreed fairly well with the uncorrected 1982 results. Helium anomalies were confirmed and expanded in the three general anomaly areas, with a few additional anomalous points elsewhere (Plate 2). These anomalies could be due to geothermal sources, but they might also be due to helium rising from depth along faults. Oil company seismic surveys in the basin (proprietary data) have discovered several NE-trending normal. faults. Segments of one or more of 
these faults could provide conduits for helium to rise to the surface from depth. This could happen with or without the presence of hot water in the fault conduits.

Let us first discuss anomaly area $\mathbb{N}_{1} 1$ near the Tazlina-Copper River junction. Plate 5 shows the distribution of $\mathrm{He}, \mathrm{Hg}$ and self-potential anomalies in this area. The many anomalous $\mathrm{Hg}$ values might seem to indicate a significant, possible geothermal area, but cannot be considered as positive geothermal indicators because they could also be caused by human contamination in this populated area. The self-potential anomalies, while large enough to be significant, have a fairly short wave length, suggesting a source depth of only a few hundred feet, and many are close to a river where ground water flow between the river and the surroundirg sediments could cause self-potential anomalies. Therefore, S-P appears to be a neutral geothermal indicator here. The controlled-source audio magnetotelluric survey may be the most definitive method for this area. Indeed, very low electrical resistivity was observed at a depth of about $2500 \mathrm{ft}$. The low resistivity layer seems to be fairly thin and to be underlain by higher resistivity sediments. Measurements in the Klawas 1 area also show low resistivity at a corresponding depth in the section (assuming the bedding is approximately horizontal between these areas of the basin). The mud coming from the Lower Klawasi mud volcano is very low resistivity, $(0.2 \Omega-\mathrm{m})$ suggesting that a saline (marine) mud or clay layer could be the source of the low resistivity anomaly in both areas. Thus we conclude that, although a geothermal resource may exist under the Tazlina area, it is equally likely that the observed anomalies could be due to nongeothermal phenomena.

In the Klawasi anomaly areas the case for geothermal resources is not encouraging. The two 1982 helium anomaly areas (Plate 1) were reconfirmed and 
extended by the 1984 survey, (Plates 2 and 3 ) but the helium may simply be rising to the surface along faults that do not necessarily contain hot water. The fairly extensive mercury survey (Plate 4) showed a few samples in anomaly area No. 3 of 3 to 7 times background and one sample in anomaly area No. 5 of 5 to 7 times background. These may be significant, and are not likely due to human contamination, but they are so few in number that it is difficult to attach much importance to them. The 1984 self-potential survey line between anomaly areas 3 and 5 did not produce a very large anomaly. The primary anomaly in the self-potential data is the steep gradient along the old $\mathrm{N}-\mathrm{S}$ seismic line near the intersection with the $\mathrm{E}-\mathrm{W}$ seismic line in sections 21 and 16 (Plate 6). It is more pronounced than the S-P anomaly we measured in 1982. Unfortunately that area does not show helium anomalies, or much of a mercury anomaly.

After our 1982 survey we were uncertain as to whether we had encountered seasonally frozen ground or permafrost in the Klawasi area. The deep electrical survey which traversed from He anomaly No. 3 to No. 5 revealed several telling facts. The resistivity nearest the surface is high, and indicates extensive, probably thick, permafrost. Below the permafrost at a depth of about $3-4000 \mathrm{ft}$ we found very low resistivity. If we had not been able to sample the clay coming from the Lower Klawasi mud volcano we might have suspected that the very low resistivity was due to a geothermal reservolr. However, the Klawas 1 clay has a resistivity of only $0.2 \Omega-m$, and the low resistivity layer depth is about right for the source of the mud. We therefore conclude that the low resistivity is probably due to a saline marine clay layer rather than a geothermal leservoir. The resistivity survey does not show any significant differences between the He anomaly areas and the normal background He areas between them. 
The Klawasi helium anomaly areas are underlain by thick permafrost. If there were a significant geothermal heat source under these helium anomalies, the heat would have to be removed laterally by cold ground water flow through thawed sediments beneath the permafrost. Although we have not measured the permeability of the glacial lake sediments that fill the basin, those sediments exposed in river bluffs appear fairly impermeable, and unlikely to permit large groundwater flow rates.

Hawkins and Motyka (1985) have done extensive analysis of the Klawasi nud volcano waters, and have concluded that their chemistry is consistent with filtration through a clay membrane, but does not require a geothermal source.

In conclusion, the extensive permafrost and the lack of a likely mechanism to remove heat laterally beneath the permafrost; together with equivocal survey results and non-geothermal water chemistry, argues against the presence of significant geothermal resources in the Klawasi mud volcano area. The situation in the Tazlina area is less clear. There is little or no permafrost in this area and the results of our geophysical and geochemical surveys are essentially equivocal. The only way to further evaluate the potential for geothermal resources in this area would be to drill one or more test holes to measure thermal gradients. The CSAMT survey suggests that if present at all, a geothermal reservolr would probably correspond to the low resistivity layer detected at approximately $2500 \mathrm{ft}$. depth.

\section{References}

Hawkins, D.B. and Motyka, R.J., 1985: A multivariate statistical analysis and chemical mass balance analys is of: waters of the Copper River bas in, Alaska, in Wallick, E. and Hitchon, B., eds., Proceedings of lst Annual Canadian - American Conference on Hydrogeology, Banf, Alberta, 1984 (in press). 


\section{ACKNOWLEDGEMENTS}

Financial support for the 1982 plart of this project was provided by a contract from the Alaska Division of Geological and Geophysical Surveys (ADGGS). Additional field support for 1982 follow-on helium soil gas surveying was provided by Ahtna Regional Corporation, arranged by Tom Craig and Clyde Stoltzfus of the Copper River Native Association. Roman Motyka and John Decker of ADGGS provided liason and planning for the aeromagnetic survey. Motyka also supervised helicopter logistics and interfacing of ongoing ADGGS geochemical studies with our work. Clay Nicholls of ADGGS visited the field site and made many helpful suggestions, as well as assisting with logistics problems.

The 1984 part of the project was funded by the State of Alaska through a contract with the Copper River Native Association, and by a grant from the U.S. Department of Energy.

We thank William Sill of the University of Utah Regearch Institute for his helpful comments on our self-potential survey and David Barnes and William Isherwood of the USGS for sharing their unpublished data and useful comments on our gravity survey. Juergen Kienle made many helpful suggestions regarding interpretation of the gravity and aeromagnetic data.

William Witte, Lorraine Wolf, Gary Bender, and Becky Petzinger assisted with data analysis. Field assistance was ably provided by Gary Bender, David Bratt, Robin Cottrell, Gabrielle de la Roche, Becky Petzinger, Patricia Moore, Mary Moorman and Lorraine Wolf. We thank Bob Hites of Soloy Helicopter operations for his consistently excellent flying.

We also thank Mrs. Katherine Ashley and her staff at the Copper River Lodge for their hospitality during our field work. 

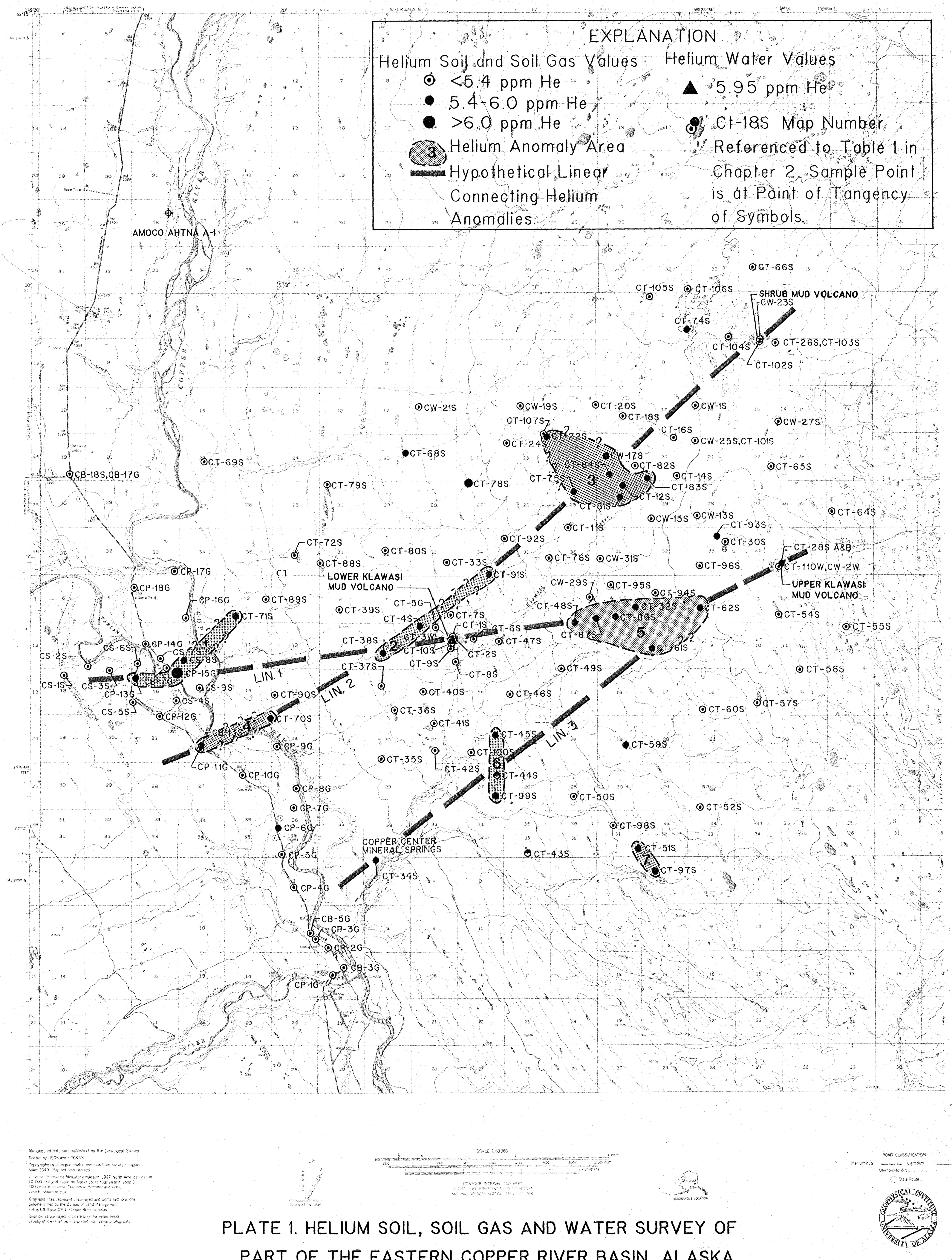

PLATE 1. HELIUM SOIL, SOIL GAS AND WATER SURVEY OF

PART OF THE EASTERN COPPER RIVER BASIN, ALASKA

by

Donald L. Turner and Eugene M. Wescott 


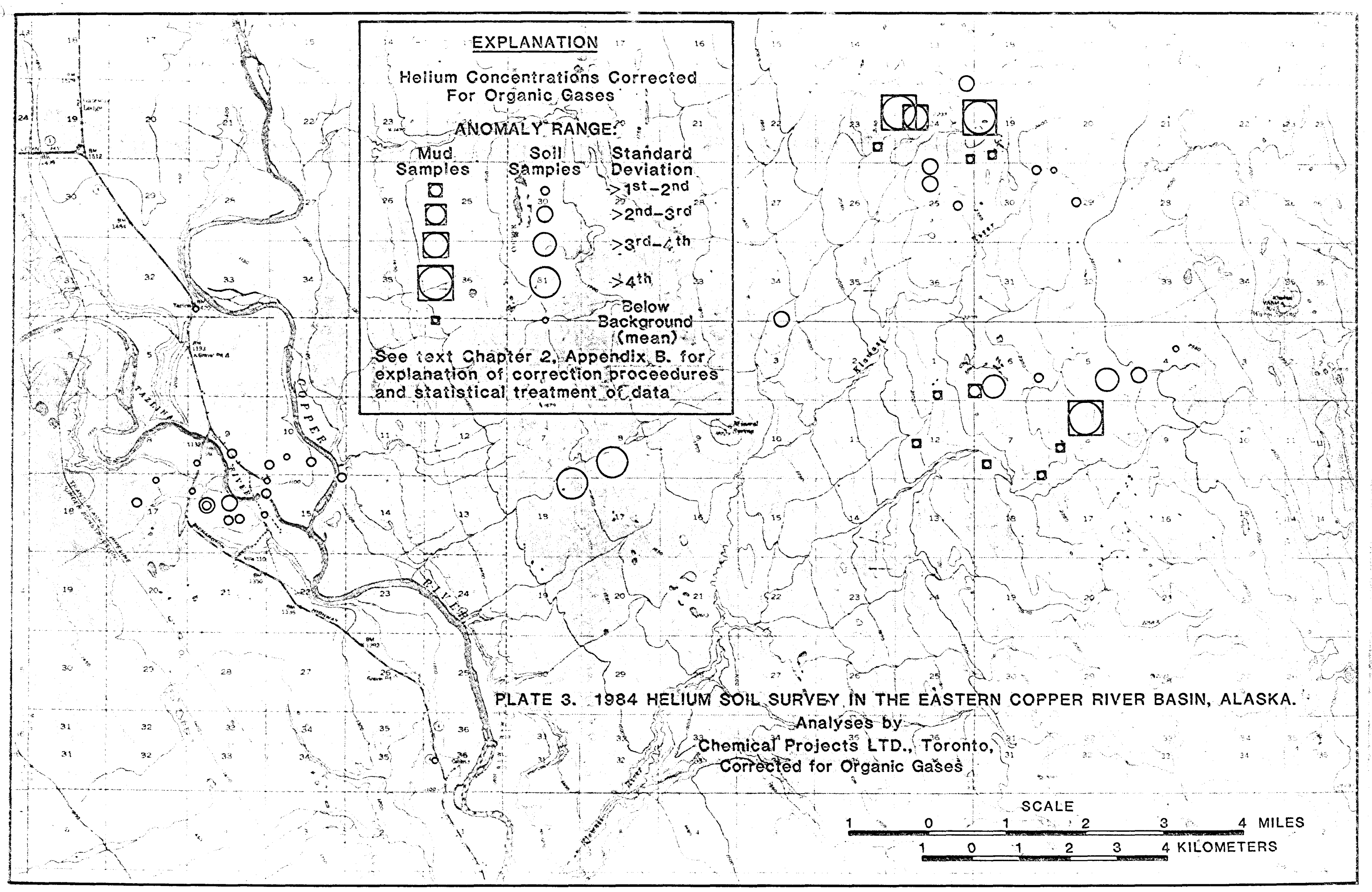




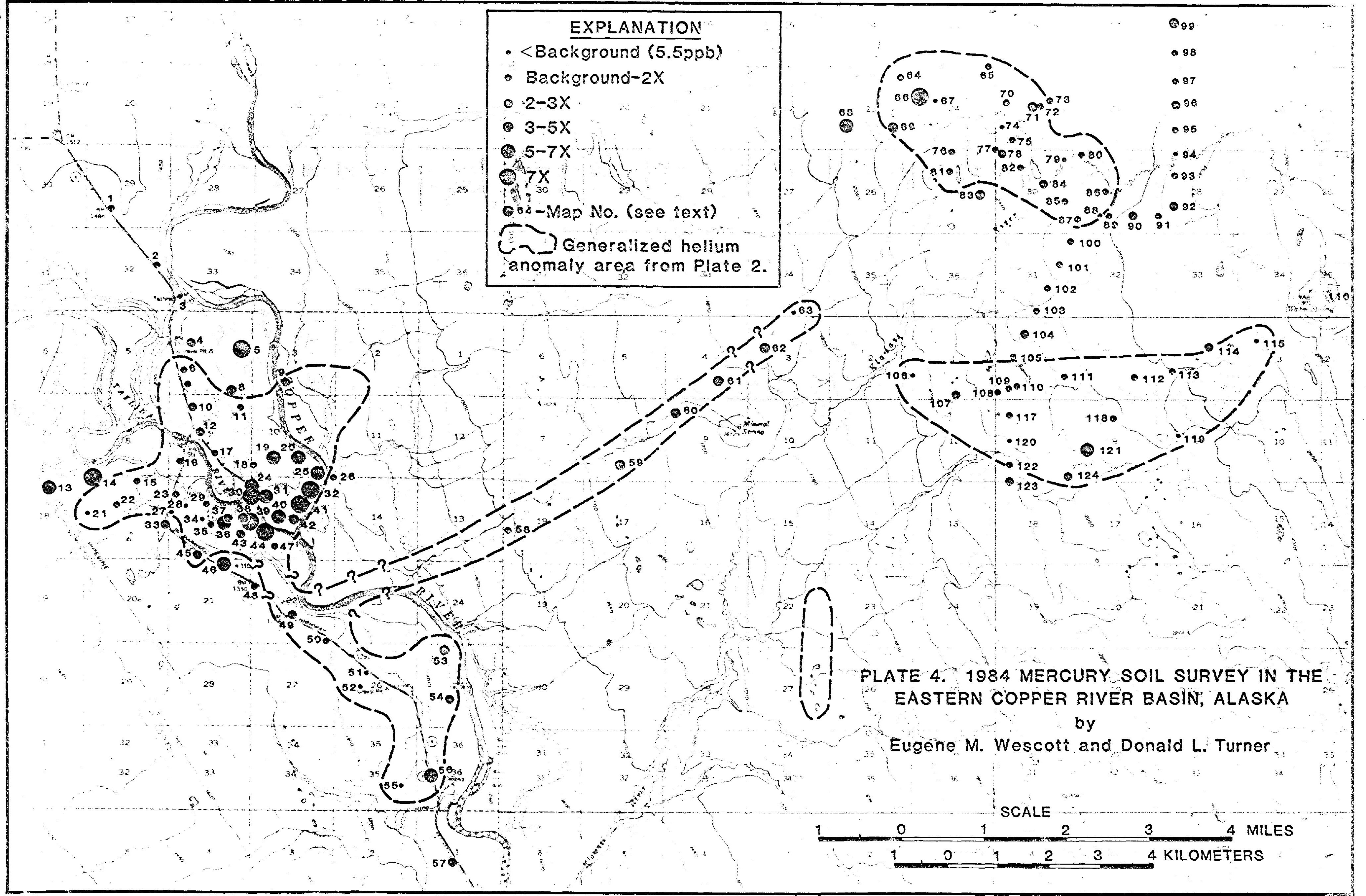




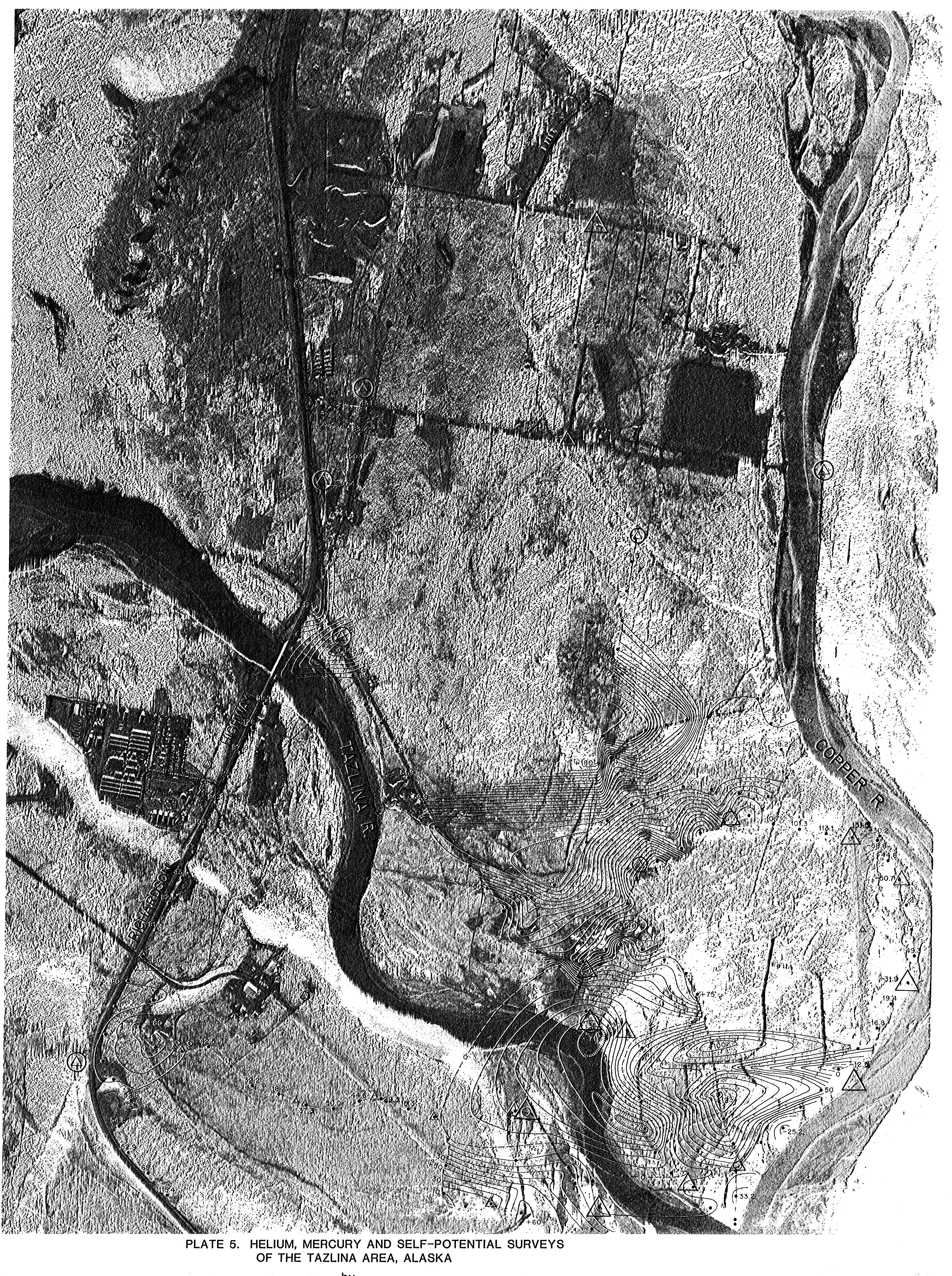

Mercury Values (ppb) Helium Values (ppb)

EXPLANATION

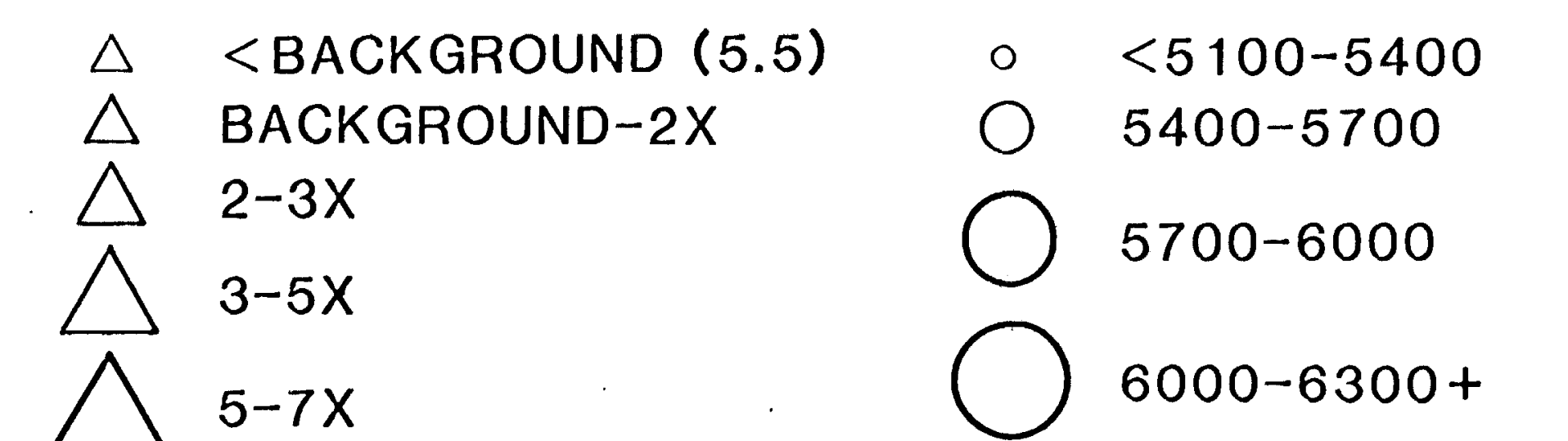

32.2 Self-Potential Station Locality and Valu (nements)

TAZLINA 5343

ENLARGED FROM AERIAL PHOTOGRAPHS DATED $5.31 \cdot 75$ BY BLM DIVISION OF TECHNICAL SERVICES

BRANCH OF PHOTOGRAMMETRY $7 \cdot 7.77$

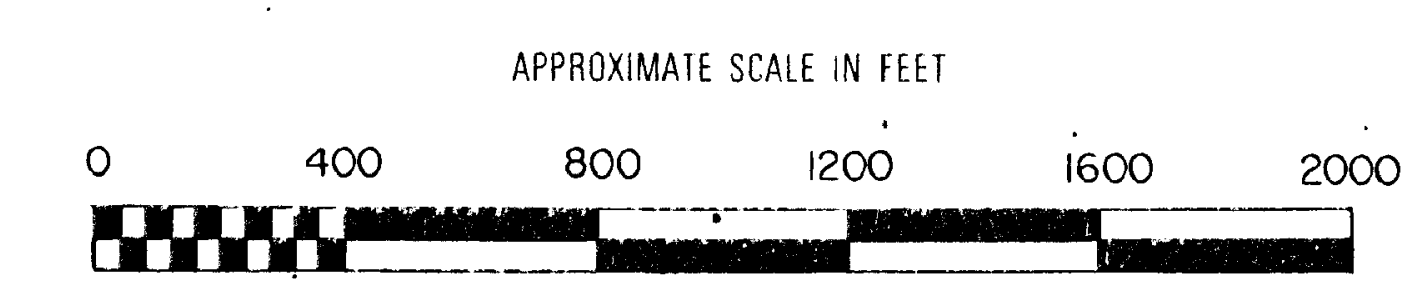



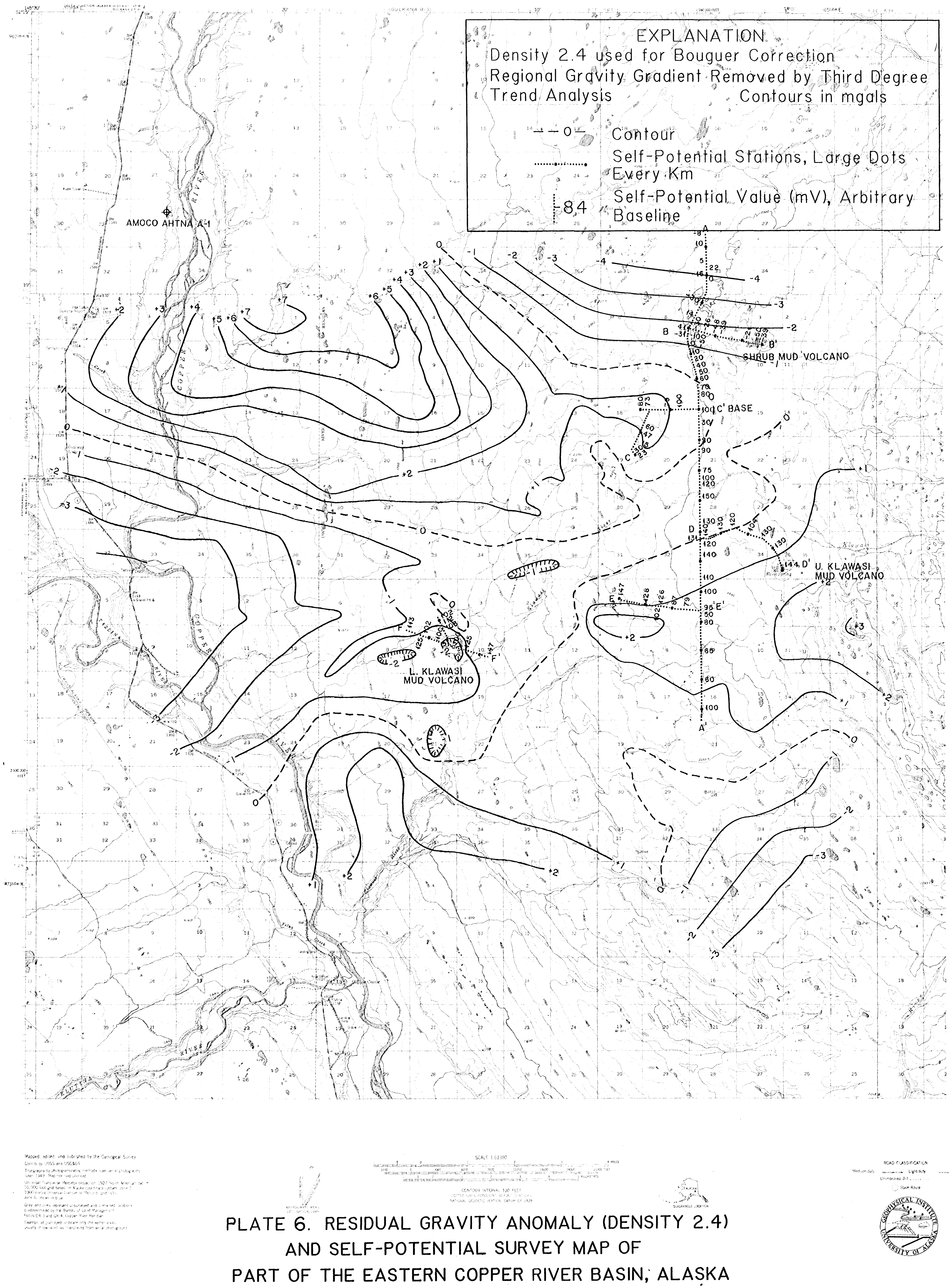
EXPLANATION

Density 2.67 used for Bouguer Correction

$\checkmark$ alues Terrain Corrected to a Radius of

$8576 \mathrm{ft}$ (Hammer H Ring) Contours in mgals

- Geophysical Institute Station.

- Barnes et al. (1958-1960) Station

+ Isherwood (1981) Station

AMOCO AHTNA A-1

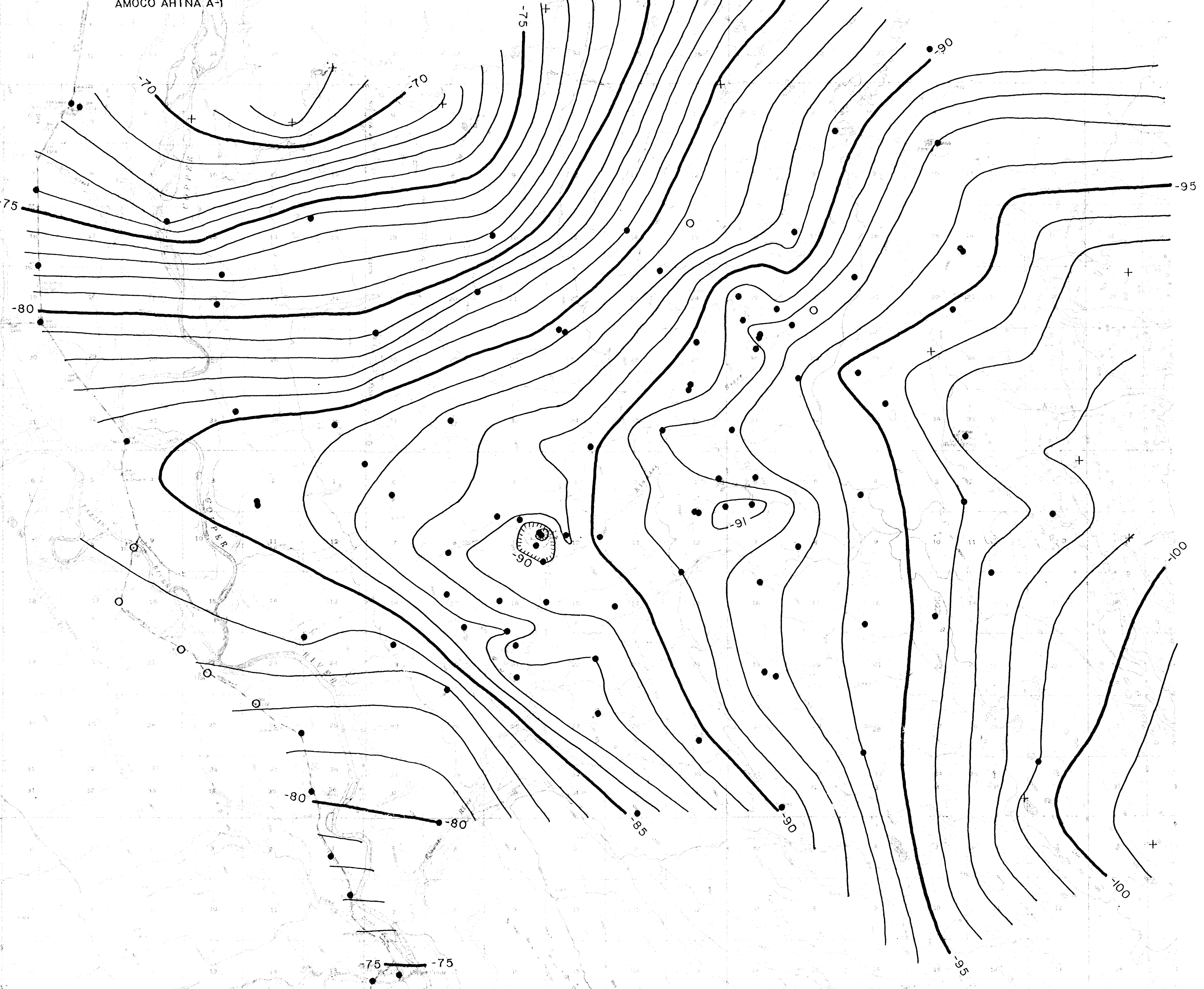

PLATE 7. COMPLETE BOUgUER GRAVITY ANOMALY MAP (DENSITY 2.67) OF PART OF THE EASTERN COPPER RIVER BASIN, ALASKA 
